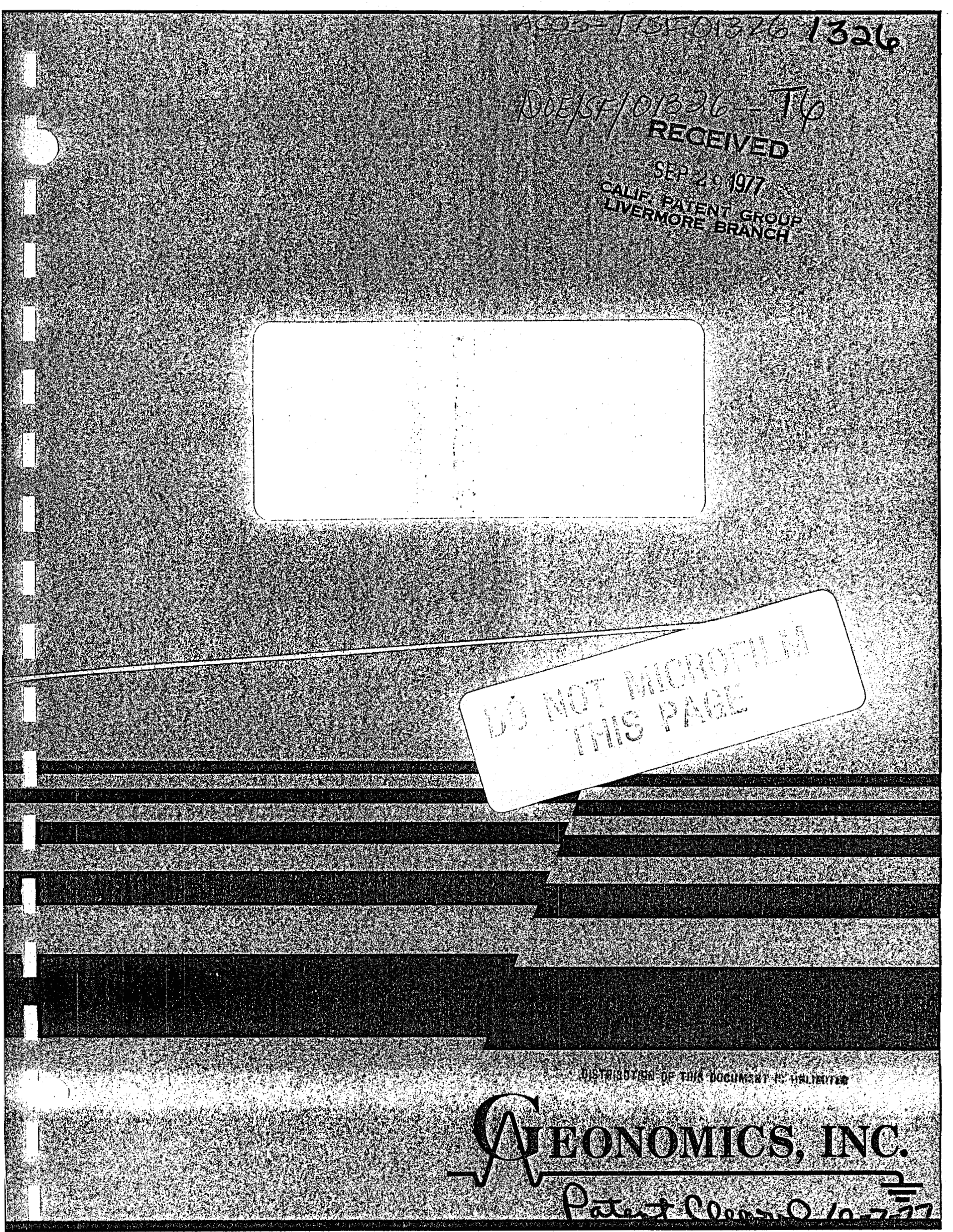


A Eonomics, inc.

FINAL REPORT

DOE/SF/01326--T6

DE84 002617

DIRECT-HEAT APPLICATIONS OF GEÓTHERMAL ENERGY IN THE GEYSERS/CLEAR LAKE REGION

VOLUME II

ENVIRONMENTAL ASSESSMENT

Prepared by

ECOVIEW

as subcontractor to

GEONOMICS, INC.

3165 ADELINE STREET

BERKELEY， CALIFORNIA 94705

AUGUST 1977

GEONOMICS PROJECT NO. 76.0132

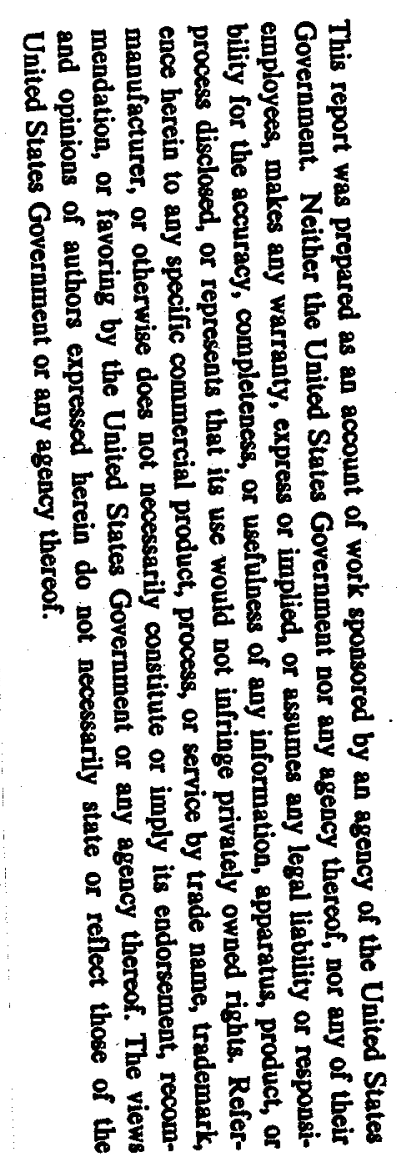

Prepared for

ENERGY RESEARCH AND DEVELOPMENT ADMINISTRATION DIVISION OF GEOTHERMAL ENERGY

Under Contract No. EG-77-C-03-1326

Submitted to

ENERGY RESEARCH AND DEVELOPMENT ADMINISTRATION

GEOTHERMAL ENERGY DIVISION

SAN FRANCISCO OPERATIONS

1333 BROADWAY

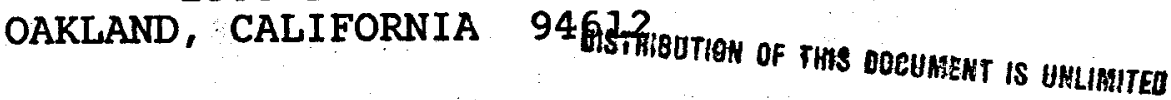




\section{DISCLAIMER}

This report was prepared as an account of work sponsored by an agency of the United States Government. Neither the United States Government nor any agency Thereof, nor any of their employees, makes any warranty, express or implied, or assumes any legal liability or responsibility for the accuracy, completeness, or usefulness of any information, apparatus, product, or process disclosed, or represents that its use would not infringe privately owned rights. Reference herein to any specific commercial product, process, or service by trade name, trademark, manufacturer, or otherwise does not necessarily constitute or imply its endorsement, recommendation, or favoring by the United States Government or any agency thereof. The views and opinions of authors expressed herein do not necessarily state or reflect those of the United States Government or any agency thereof. 


\section{DISCLAIMER}

Portions of this document may be illegible in electronic image products. Images are produced from the best available original document. 


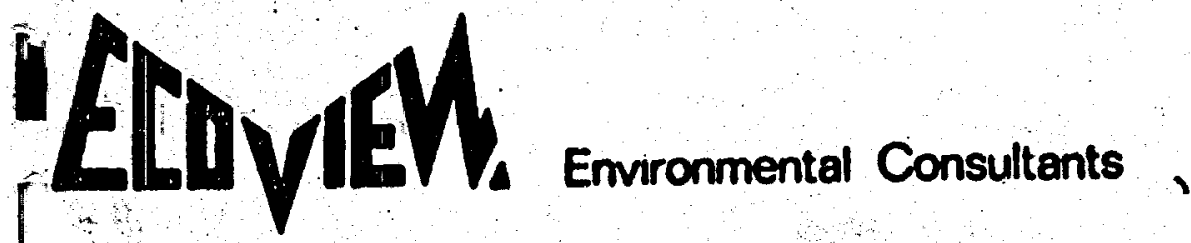

b

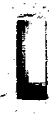

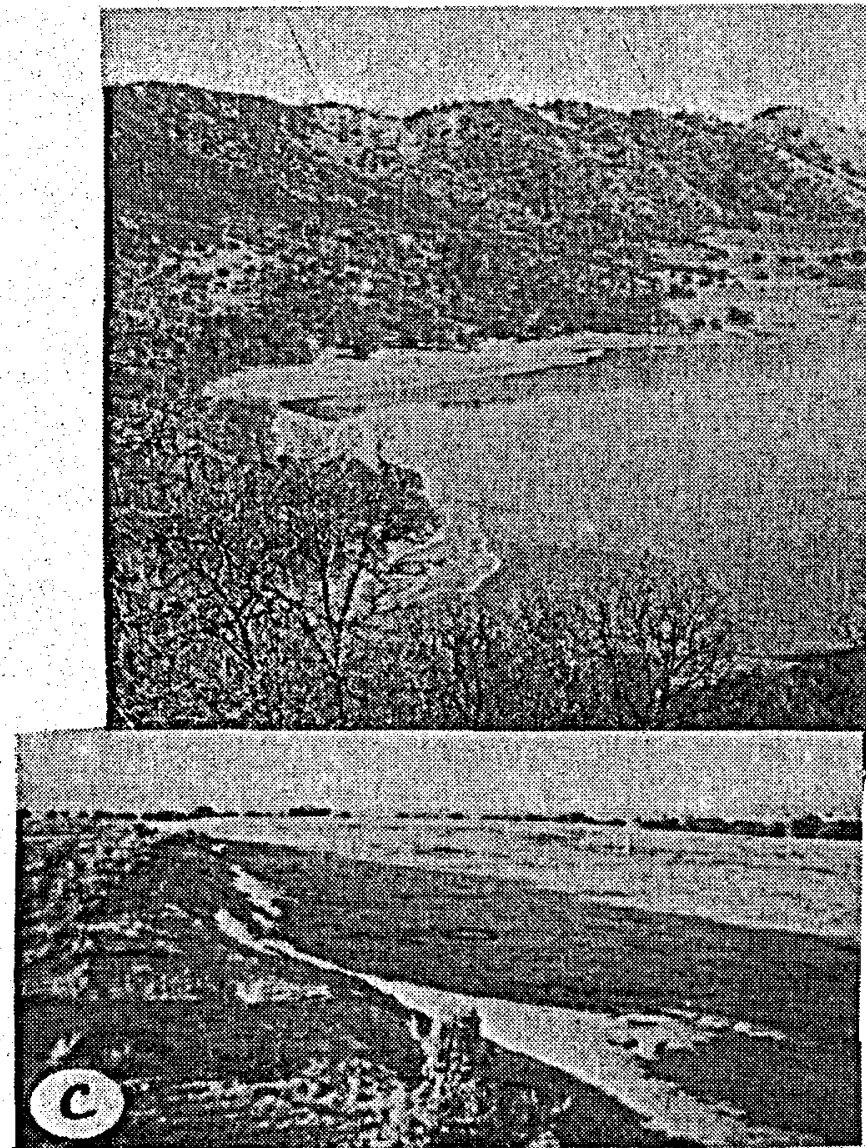

A
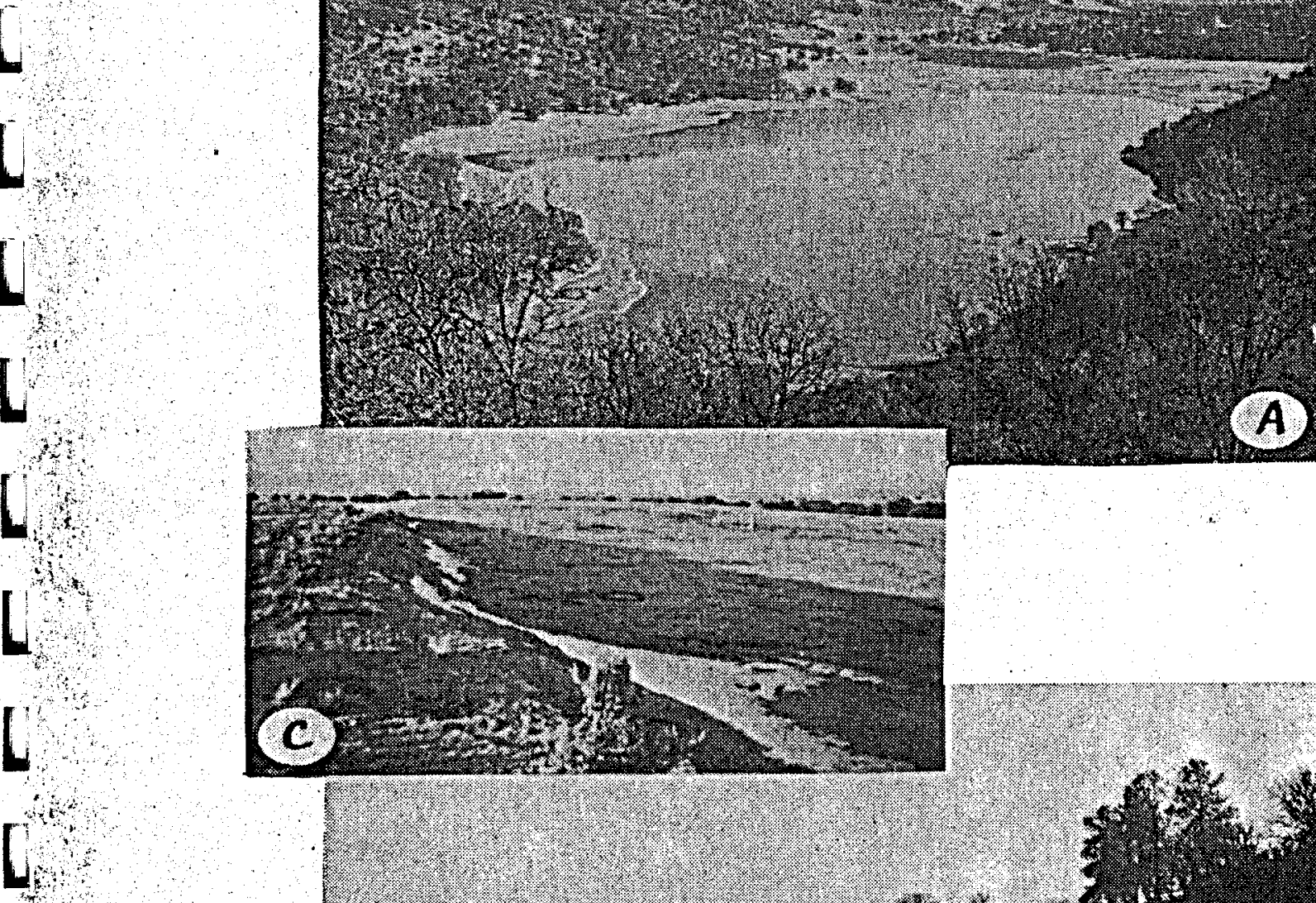

4

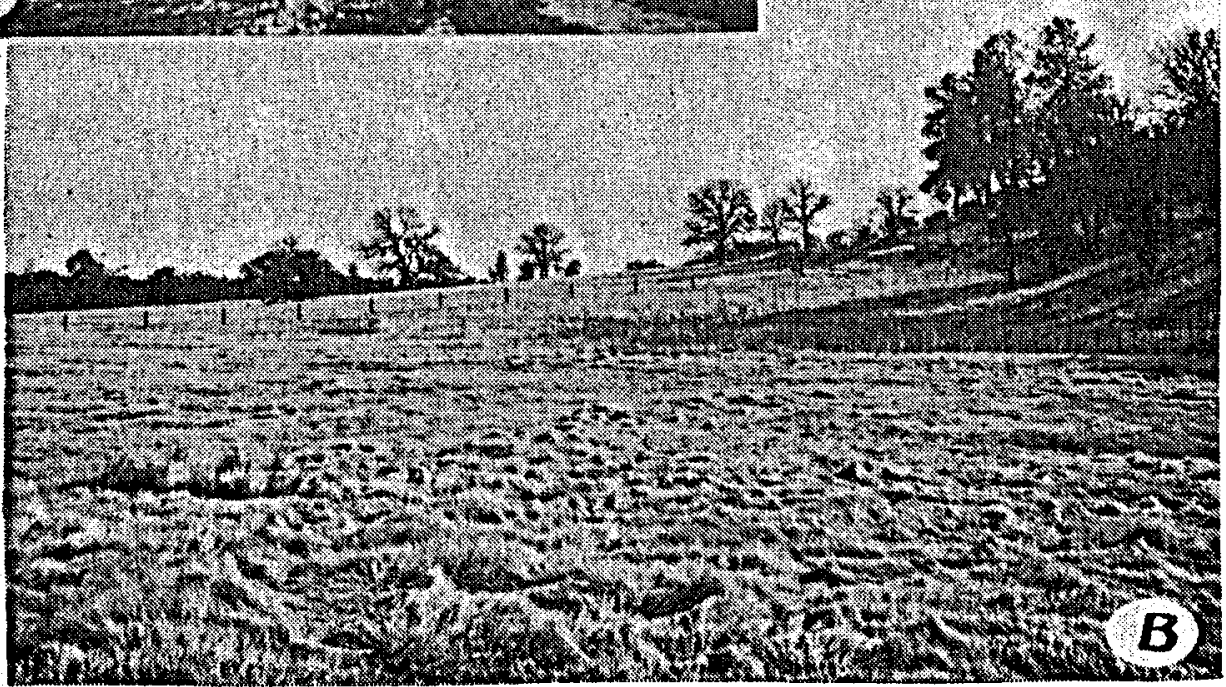

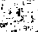

FRONTISPIECE: (A) General overview of Borax Lake looking east.

(B) The grassland and savannah at the base of the ridges on the north side of Borax Lake.

(C) The salt marsh at the eastern end of the Lake. 
I. STUDY AREA I GENERAL ASPECTS Area Characteristics - * : :

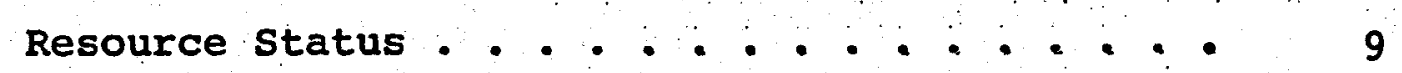

II. THE AIR RESOURCE STATUS AND QUALITY climate - . . . . . . . . . . . . . 9 Air Quality . . . . . . . . . . . . 12 The Effects of Nonelectrical Development on climate and Air Quality . . . . . . . . . . 20

III. THE WATER RESOURCE - STATUS AND QUALITY Hydrology - . . . . . . . . . . . . . . 21 water Quality . . . . .............. 22 Iim nology of Borax Lake . . . . . . . . . . . 25. The Effect of Nonelectrical Development on Hydrology and Water Quality . . . . . . 37

IV. TEE VEGETATION RESOURCE Plant Communities . . . . . . . . . 41 Rare and Endangered Species . . . . . . . . . 48

V. THE FAUNAL RESOURCE Faunal Habitats . . . . . . . . . . . . . 50 Rare and Endangered Species . . . . . . . . . 55 add APPEANDIX I: (DETERMINATION OF WIND DATA 
Environmental Consultants

\section{LIST OF FIGURES}

Figure 1 Evapotranspiration curve . . . . . . . . . 11

Figure 2 Local Wind Flow Pattern . . .". . . . . . 13

Figure 3 Average of Hourly Ozone Reading . . . . . . 14

Figure 4: Average of Hourly Nitrogen Oxide

Concentrations . . . . . . . . . 15

Figure 5 Average of Hourly Coefficient of Haze . . . 15

Figure 6 Sampling site of Fredericksen Engineering . 16

Figure 7 Water Drainage Patterns . . . . . . . . 23

Figure 8, Water Quality Sampling sites . . . . . . 24

Figure 9 Physical Characteristics of Borax Lake $\therefore$. 27

Figure 10 Yearly Cycle of Incident solar Radiation

and Water Temperature . . . . . . . 28

Figure 11 Turbidity and Transparency Cycle . . . . . 29

Figure 12 The Fields of sulfur species in Relation

to Oxygen ................ . . . 31

Figure 13 Algal Physiological Adaptability tó Borax - 33

Figure 14 Comparison of Floral Components productivity 36

Figure 15 Schematic Cross-section of Borax Lake

Watershed ..................... 38

- Figure 16 Vegetation Types of Borax Lake _. . . . 40

Figure 17 vegetation Communities of Borax Lake $\quad \ldots 51$

\section{LIST OF TABLES}

Table 1 Temperature Means and Extremes . . . . . 10

Table 2 Average Monthly and Seasonal Precipitation .10

Table 3 Average Annual and Seasonal Snowfall . . . 10

Table 4 Summary of California Air Resource Board

Mobile Unit Monitoring data . . . . . 17 
Environmental Consultants

\section{IIST OF TABLES (Cont.)}

Table 5 Air Quality Sampling Results from Fredericksen Engineering . . . . . 17

Table 6 LCAPCD: Sulfur Analysis for September 1976 • . 18

Table 7 ICAPCD: Sulfur Analysis for September 1976 • 19

Table 8 Water Sampling Results of the Borax Iake

Basin . . . . . . . . . . . . 24

Table 9 Water sampling Results for High Valley

Wells . . . . . . . . . . . . 26

Table 10 Limnological Characteristics of Borax Lake.. . . 27

Table 11 Analysis of surface Water for Borax Lake . . . 30

Table 12 Comparison of Primary Productivity with

Several Lakes . . . . . . . . . 35

Table 13 Characteristic Birds of Woodland communities . . 61

Table 14 Characteristic Birds of Grassland/Savannah

Communities ................ 62 


\title{
Environmental Consultants
}

\author{
I. STUDY AREA I GENERAI ASPECTS
}

\section{Area Characteristics}

This area, on the northeast side of clear Lake, encompasses approximately 65 square miles. The terrain is mostly mountainous; however, several broad valleys and alluvial areas comprise about 208 of the total area. Elevations range from about 1300 feet to 2500 feet above mean sea level.

The lakeside towns of Clear Lake Oaks, Clear Lake Park, and Clear Lake Highlands are immediately adjacent to the potential geothermal field. Agricultural areas have been developed at High Valley. Sulphur Bank Mine Valley, and Burns Valley.

This area can be effectively divided into three segments:

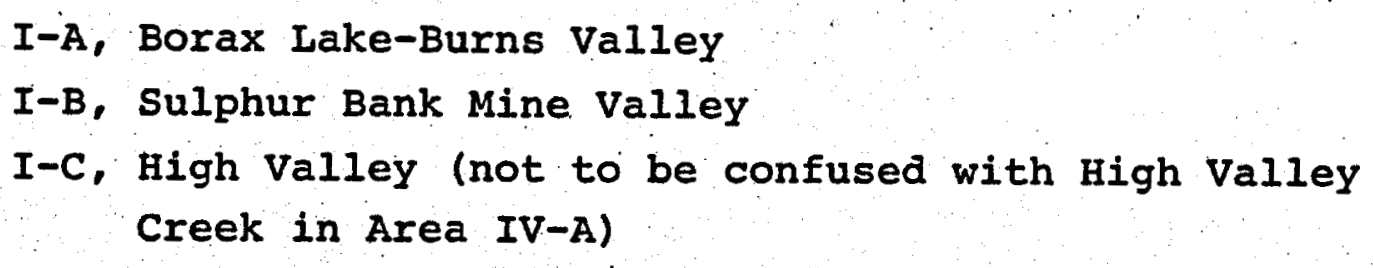

The general aspects of each of these areas lend themselves to the same or different applications of nonelectrical uses as amenities permit.

Borax Lake - Burns Valley (Area I-A)

Borax Lake - Burns Valley is proximal to one of the denser population centers on clear Lake. The towns of clear Lake Park and Clear I ake Highlands provide an opportunity to apply municipal space heating and cooling for its citizens as well as a 


\section{Environmental Consultants}

potential for agribusiness, commercial processing etc. in a narrow band of area adjacent to the foothills.

In the preparation of the Borax Lake EIR ECOVIEW suggested several possibilities of nonelectrical uses as an adjunct to electrical generation. However, the drilling of an exploratory well at Borax Lake has been blocked, at least temporarily, by public pressure until there is a decision by the Lake County Board of Supervisors.

Until the nature of the resource is clearly identified by deep drilling it will be very difficult to ascertain the best applications for that area.

If the resource is hot water as good or better than the proven wells at Sulphur Bank then the following environmentally acceptable uses should be considered:

- A local utility district to generate and distribute electricity for local uses.

-- Agribusiness operations particularly livestock feed, cut flower, mushroom nursery stock, or food processing. Poultry or livestock feeding coupled with shrimp or fish production is also an adaptable operation in the vicinity but remote from recreation and housing areas.

The environmental constraints that affect geothermal planning in this area are:

- Geothermal water purification to equivalent clear Lake step.

-- Transportation: Lack of a good connecting outlet to 


\section{Environmental Consultants}

Highway 20. The route over the ridge from sulphur Bank is steep and significant improvements would have a negative aesthetic impact because of the excessive grade.

Phililps Petroleum, Inc., the developer of the proposed exploratory well at Borax Iake, has publicly stated that if a well was developed that was not profitable for electrical generation then it would be given back to the landowners or to the county for use as they saw fit.

The actual boundary between leased and unleased land for geothermal development is not completely clear. All municipal areas are not leased and most of the adjacent open land of low relief is not leased. Federal land just north and adjacent to Burns Valley is being considered for lease under the Federal Geothermal Leasing Plan.

The existing route through Burns Valiey or through clear Lake Highlands and Clear Lake Park is narrow, conjested and undesirable for commercial transport.

Aesthetics: Any development geothermal, electric and nonelectric will have to be compatable aesthetically, visually, audibly and odorally to the retirement and recreational community that now is the principal support of the area.

Nature Areas: The question of land use in and around Borax lake is a political decision that must be clarified prior to committment to any geothermal development. 
-- Resources: The use of labor intensive enterprises would be very beneficial to this area. Both senior citizens and younger people should be, considered.

- The availability of fresh water as an adjunct to geothermal water of high salinity must be considered in regard to volume to be used and the constancy of source, since the lake water is strictly controlled by intercounty agreements. There is good reason to reconsider the possibility. of reopening the English Ridge Irrigation project of the Department of Water Resources as a source of non-saline water. A study and demonstration of reclaiming geothermal. waters for domestic and agricultural purposes should obtain high priority.

The Sulphur Bank Mine: (Area I-B)

This area is a small valiey that once supported a cattle breeding ranch, almond and walnut orchards. Some elements of each still remain but only on a small scale. The mine itself is a large surface excavation covering some 50 to 60 acres. A portion of the lake side area is reserved for use as an Indian Reservation. A large marina type development has encroached on much of the lowland pastures and some walnut orchards. The town of clear lake Oaks lies between the edge of the lake and the foothills immediately west of the valley. Highway 20 goes through the north central portion of the valley.

Two hot water wells of substantial capacity and high heat have been developed on Bradley Mining Company Lands about one-half mile from the mine. 


\section{Environmental Consultants}

There is considerable land \pm 400 acres leased for electrical production suitable for development for a variety of geothermal purposes, however, the choice of applications is limited by possible conflicts of land uses in various areas.

The most likely applications of geothermal energy in this unit are:

-- Local utility district for all municipal operations: e. 9.,

1. Municipal electrical generating "

2. Space heating and cooling for homes and businesses

3. Operated sewage and solid waste disposal.

4. Water supply treatment facility using spent geothermal water for domestic supplies

- Agribusiness operations

1. Greenhouse operations particularly vegetables and possibly cut flowers

2. Algae growing and harvesting and processing

3. Mushroom growing

4. Certain types of aquaculture

5. Iivestock feed production

-- Commercial operations

1. Lumber processing and curing

2. Dehydration

3. Cryogenic processing

4. Pharmaceutical processing

5. Specialized food processing 
The special environmental constraints are:

-- Aesthetics: Visual, audibleand odoral aspects of any proposed project in this area should be given very high priority.

- Water quality maintenance is next most important and the same concerns voiced for Borax Lake apply here.

-- Transportation: Careful planning needs to be exercised regarding the siting of projects in this area to avoid undue congestion and traffic flow patterns in clear lake oaks and at important intersections. If feed production operations are located close to existing wells, for instance, and cattle are held in High Valley, traffic con estion and noise will be increased between sulphur Bank and the access road to Eigh Valley. The most sensitive point is the elementary school at the junction of Highway 20 and High Valley Road.

Truck traffic using Highway 20 westward should have negligible effect. Truck traffic between Upper Lake and Sulphur Bank will be relatively inefficient because of the numerous small towns along the route and the tortuous alignment bordering the Lake. This alone may discourage lumber transport to possible geothermally powered processing plants suggested for this area.

- Local labor resources are available in this area and again careful consideration should be given to youth and elderly for part-time or full-time employment. 
- Fresh water resources are limited and the same suggestions apply here as were stated for Borax Lake.

High Valley (Area I-C)

High Valley is located about two miles north and 600 feet higher than the Lake and separated from it by a steep grade about Clear Lake Oaks.

Access is by a steep tortuously curved road which ultimately passes through High Valley to U. S. Forest Lands beyond and to the west.

Population is yery low and rural in character. Several large ranch headquarters are located in the valley and a few small acreages appear to be developed for homesites.

All of the valley is devoted to cattle production either natural pasture or a small amount of irrigated pasture.

The vegetation is a valley oak savannah and introduced annual range land in the flats, Blue oak woodland or savannah in some places around the valley and chamise-buck brush-manzanita chaparral on most of the hillsides.

Most of the land is leased for potential geothermal development by Geothermal Resources International, Inc. with peripheral leases outside the valley by Argosy, Phillips Petroleum and Chevron Resources, Inc. A few small parcels within the valley floor are unleased.

While the full potential for nonelectrical development is 


\section{COMvironmental Consultants}

conjectural because no geothermal wells have been drilled, ancillary uses are very promising. since existing wells are hot water at Sulphur Bank that type of resource may well be expected here. Nevertheless, High Valley is well within the reach of feasible hot water delivery from Sulphur Bank so that almost any application in the field is possible. Our current estimate suggests agribusiness particularly involving livestock and related activities. If beef or dairy production were emphasized it would fit without conflict to the existing land use. Other specialty crops would also be compatible. On the one hand feed could be produced at Sulphur Bank and fed to cattle at High Valley or the water piped to the valley and a cascade of uses developed that supported livestock of various kinds. Dairying and milk processing, beef growing, feeding. and slaughter with ancillary refrigeration and processing applications, pork production in combination with shrimp and aquaculture are but a few of the possibilities. The particular advantage of this area for these purposes is the low population density of the valley, the sharp physical separation of the valley from the lakeside resorts and residential areas and the closeness of a developed resource.

The potential environmental constraints are:

-- Access roads need to be either rerouted or significantly improved.

-- Possible traffic conjestion and hazards need to be dealt with at clear Lake Oaks.

- Water quality needs to be maintained or improved and waste water reclaimed for agricultural or aquacultural uses. 
-- Odors of livestock concentration need to be controlled so that they do not impact lakeside areas.

- Siting and placement of structures and holding and rearing pens should be carefully planned so that the natural beauty of the valley is not unnecessarily impaired.

-- Adequate irrigation systems, reservoirs and holding ponds need to be integrated to the geothermal development to fully utilize the water resource.

\section{Resource Status}

Nearly all land in the vicinity has been leased for geothermal development, mostly by Geothermal Resources International (GRI) and Phillips Petroleum Company areas north and east of Glenbrook are leased by Argosy, Inc. Four exploratory wells were drilled in the early $1960^{\prime}$ 's in the sulphur Bank Mine Area, which yielded hot water as high as $400^{\circ} \mathrm{F}$. $\left(204^{\circ} \mathrm{C}.\right)$. Phillips Petroleum Company has proposed to drill a well at the north side of Borax Lake. Argosy, Inc. has an application pending before the Planning Department to drill a well north of Glen Haven, approximately two miles from the head of High Valley. The resource status within the balance of the area has been partially explored, but most of the data is proprietary. some independent resource analysis may be necessary if well drilling becomes a part of a noneleetrical project:

II. AIR RESOURCE - STATUS AND QUALITY

Climate

The Lake County's climate is characterized by moderate temperature and precipitation and a pronounced wet-winter - dry-summer season. 


\section{Environmental Consultants}

National weather Service records for the study area show that precipitation is concentrated during the six month winter period with only light amounts reported for the rest of the year. Average seasonal precipitation is 22-20 inches, including 3.5 inches of snowfall. High temperature readings occasionally exceed $100^{\circ} \mathrm{F}$ during the dry summer months and lows during the winter sometimes fall several degrees below freezing. Mean seasonal temperature is $57.7^{\circ} \mathrm{F}$. Precipitation and temperature data summaries available for the 36 years of records are presented in Tables 1,2 and 3 .

TABIE 1

AVERAGE MONTHLY AND SEASONAL PRECTPITATION $(\mathrm{cm})$

\begin{tabular}{llllllllllllllll}
\hline Jan. & Ieb. & Nar. & Apr. & May June July & Aug. & Sept. & Oct. & Nov. & Dec. & Seascn \\
\hline 11.7 & 11.6 & 6.8 & 3.5 & 1.4 & .5 & 0.01 & 0.01 & 0.7 & 2.6 & 5.7 & 11.7 & 56.3 &
\end{tabular}

TABLE 2

AVERAGE MONTHLY AND SEASONAL SNOWEALL

\begin{tabular}{|c|c|c|c|c|c|c|c|c|c|c|c|c|}
\hline Jar. & Feb. & Mar. & Apr. & May & June & July & Aug. & Sept. & oct. & Nov. & Dec. & 5rition \\
\hline 5.6 & 0.25 & 0.25 & 0.25 & - & - & - & - & - & - & - & 2.5 & 8.8 \\
\hline
\end{tabular}

TABLE 3

TEMPERATURE vEANS AND EXIREEMES • $\mathrm{C}$

\begin{tabular}{|c|c|c|c|c|c|c|c|c|c|c|c|c|c|}
\hline & Jan. & reb. & Mar. & Apr: & May & June & suly & Aug. & Sept. & Oct. & Nov. & Dec. & Year \\
\hline Highest & 25.6 & 25.6 & 30.0 & 34.4 & 38.3 & 42.2 & 42.2 & 43.3 & 41.6 & 37.7 & 30 & 29.4 & 43.3 \\
\hline $\begin{array}{l}\text { Mean } \\
\text { Maximum }\end{array}$ & 11.4 & 13.7 & 16.9 & 20.4 & 24.4 & 29.1 & 34.1 & 33.5 & 30.3 & 24.0 & 17.4 & 12.2 & 22.2 \\
\hline Mean & 5.8 & 7.6 & 10.0 & 12.6 & 16.2 & 20.2 & 24.0 & 23.0 & 20.0 & 25.1 & 10.0 & 6.6 & 14.3 \\
\hline $\begin{array}{l}\text { Mean } \\
\text { Minimum }\end{array}$ & -0.4 & 1.7 & 3.2 & 4.8 & 7.9 & 12.4 & 13.8 & 12.6 & $9 . B$ & 6.2 & 2.7 & 0.9 & 6.2 \\
\hline Lowest & -11.6 & -8.3 & -5.6 & -5.0 & -6.1 & 2.1 & 5.6 & 2.8 & -0.6 & -3.9 & -8.8 & -13.8 & -13.8 \\
\hline
\end{tabular}


Figure 1 illustrates the relationship between the temperature and moisture regimes of the project area. The graph compares precipitation with estimated evapotranspiration (water loss by evaporation and plant transpiration). This comparison shows the critical periods of plant water usage. The short period when adequate moisture supplies and warm temperatures coincide to promote rapid growth, flowering and seeding of plants is followed by a somewhat longer period of water deficit. The sharp difference between winter-spring moisture and summer drought is instrumental in the development of native plant species. The period of water deficit imposes conditions requiring intense physiological readjustment by the plants to withstand drought. As rains occur in the fall, soil moisture is replaced, aquifers recharged, and excess precipitation is removed in the form of surface run-off.

Figure 1. Evapotranspiration Curve

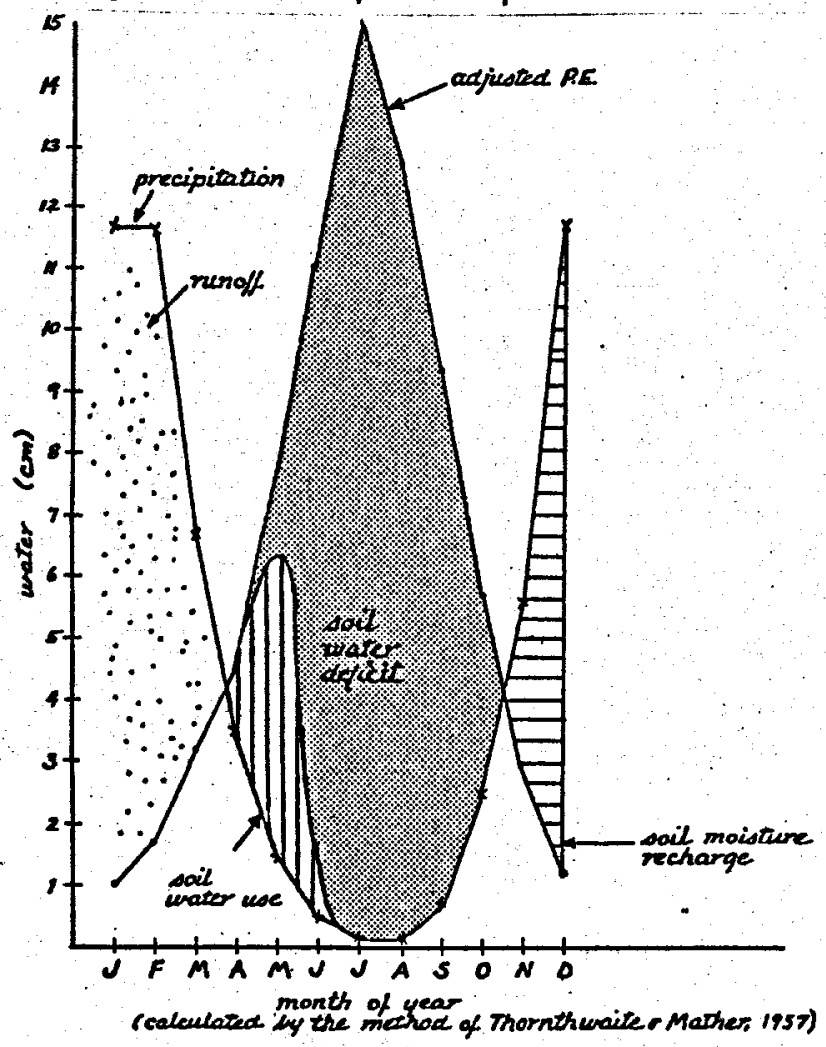




\section{Environmental Consultants}

Data on wind patterns within the Clear Lake Basin is very limited. Wind direction is profoundly influenced by local topography. The nearest station of term for which average wind direction and speed can be calculated is the Ukiah Flight Service station located about $40 \mathrm{~km}$ west-riorthwest of the study area. While the station is relatively close, iocal topographical differences makes direct transfer of data less than perfect. Adjusting for the effect of local terrain, the probable air movements are plotted in Figure 2 . Wind can be expected in the area 70 to 758 of the time. During these windy periods, the direction will be between wNW and $N 458$ of the time, and 278 between $S E$ and $S$.

\section{Air Quality}

Due to the lack of significant pollution sources, air quality in the lower clear lake area is excellent. Characterization of air quality has been the objective of three monitoring programs conducted in the past three years.

From January 9 through January 29, 1974, the California Air Resources Board conducted a short duration air quality sample in the Clearlake Highlands area southeast of the study area.

A continuous monitoring mobile unit was used to measure ozone $\left(\mathrm{O}_{z}\right)$. carbon monoxide $(\mathrm{CO})$, nitrous oxides $\left(\mathrm{NE}_{\mathrm{x}}\right)$, methane $\left(\mathrm{CH}_{4}\right)$, total hydrocarbons (THC), and the coefficient of haze (COH) - These data are summarized in Table 4 and Figures 3 , 4 and 5. At no time during the monitoring period were California Ambient Air Quality Standards excluded. 


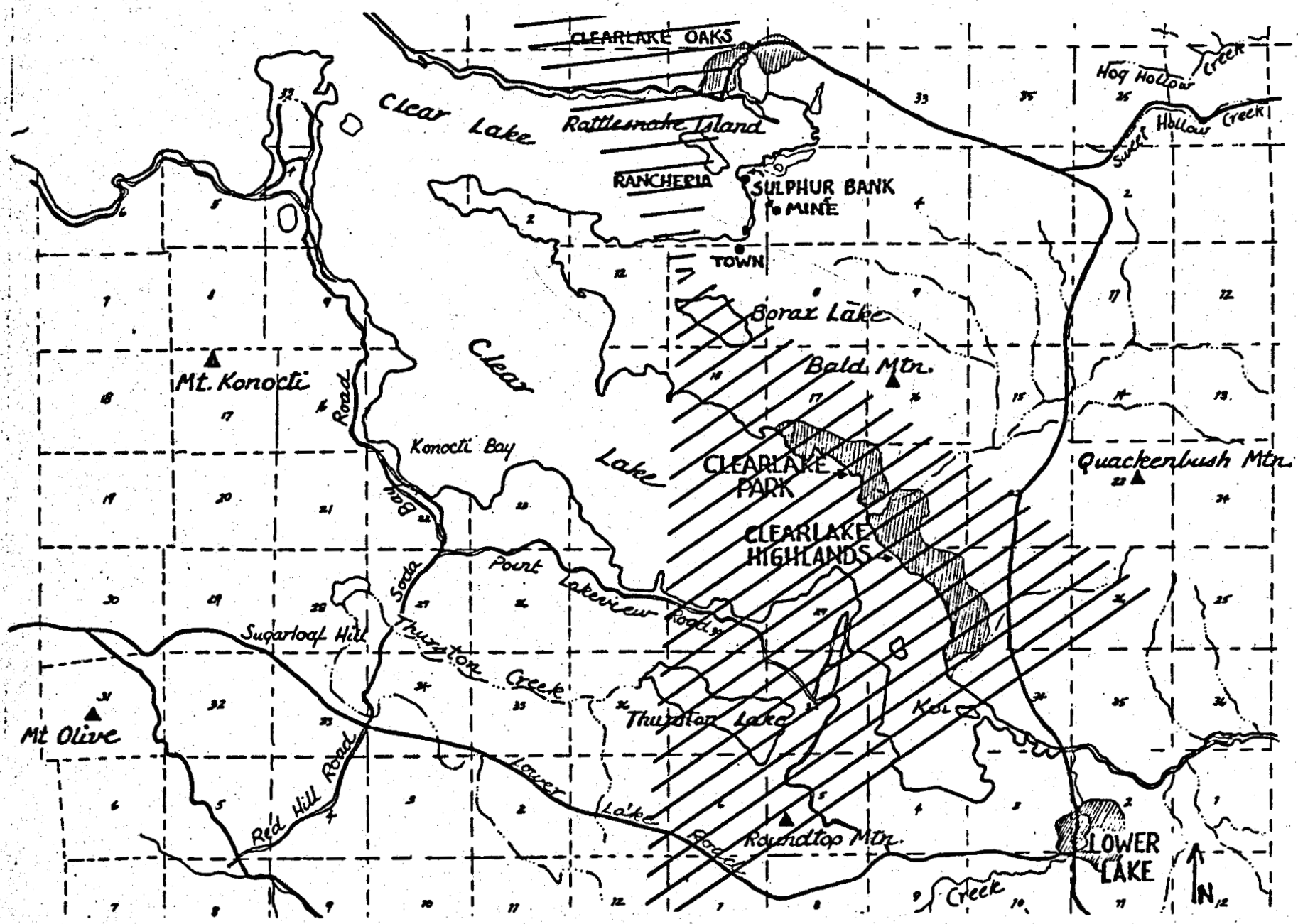

Figure 2. Local Wind Flow Pattern

The lower clear Lake area is in a broad basin elongated in a general NW-SE direction. Topographical channeling of local wind flow is relatively unrestricted. In the study area, wind flow is towards Clear Lake Park, Clear Lake Highlands and Lower Lake about $35 \%$ of the total time. Wind flow is towards Glen Haven and Clear Lake Oaks about 218 of the total time. Appendix explains how the local wind pattern was determined. 
Table 4 Summary of Mobile Unit Air Monitoring Data: Clearlake Highlands.

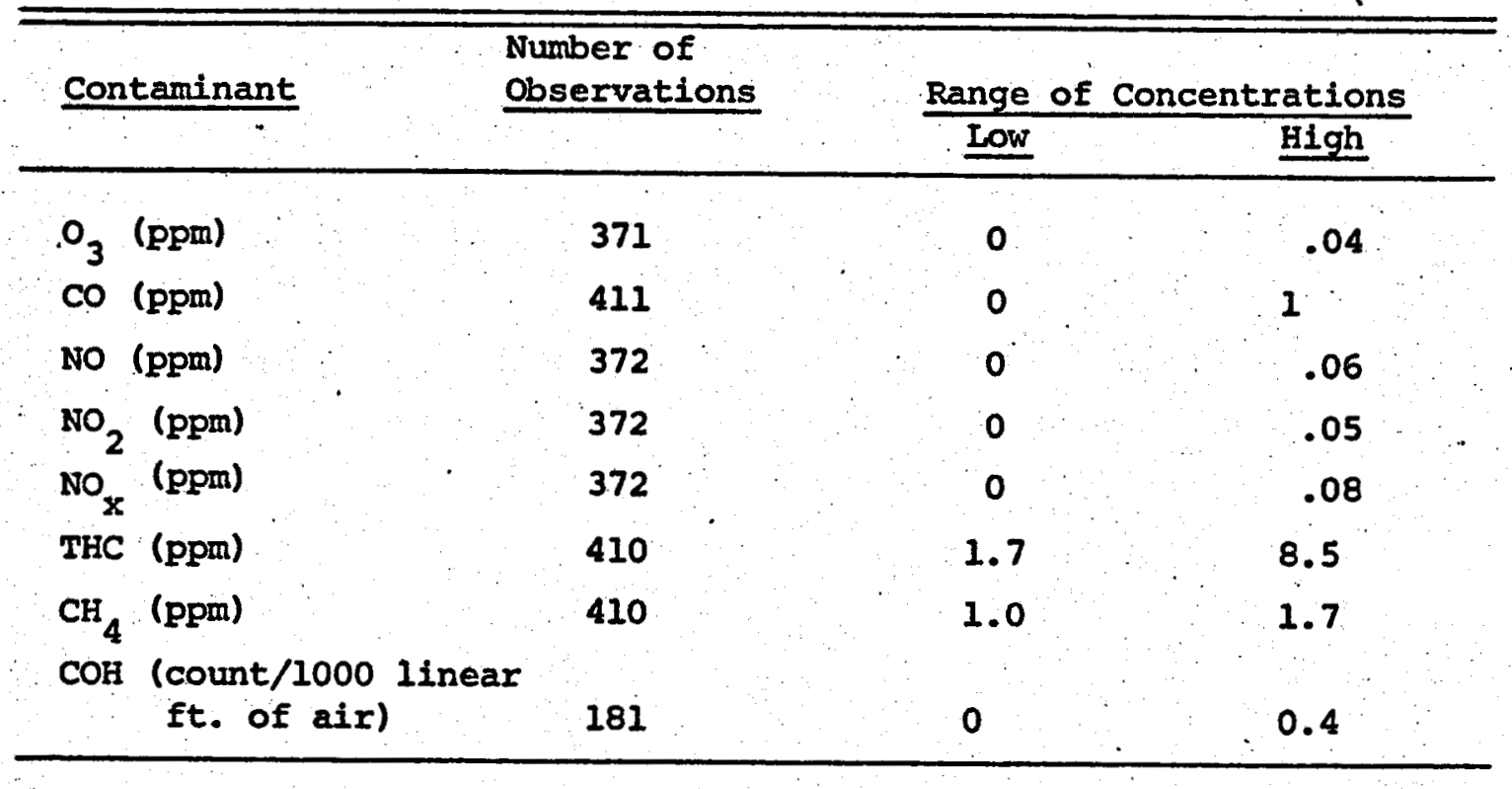

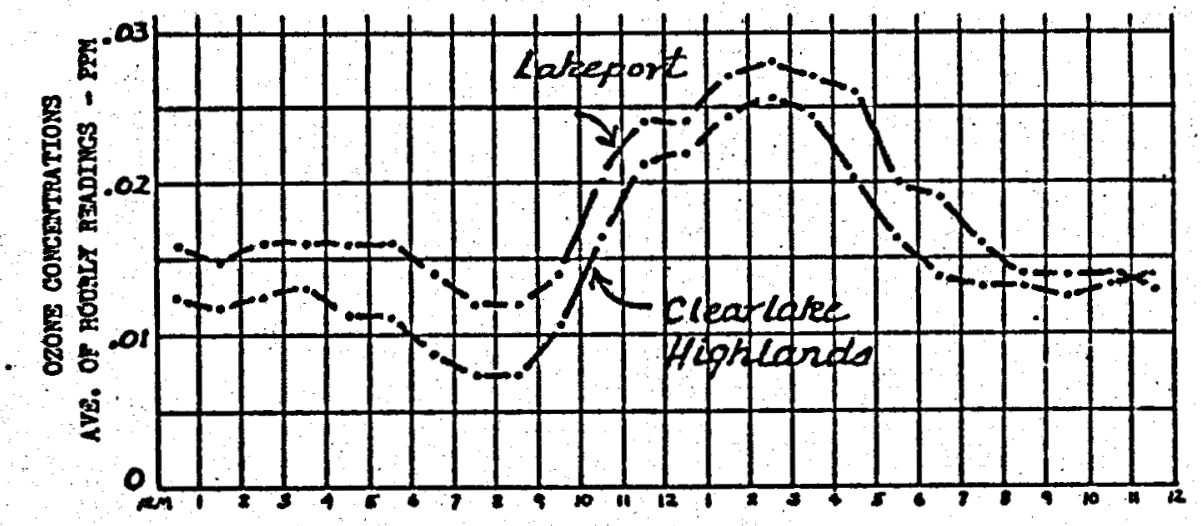

Figure 3 Maxlmum Hourly Average: 0.05 (Lakeport); 0.04 (Clearlake Highlands) Average of M.H. Averagess 0.032 and 0.027 respectively. 
A Environmental Consultants

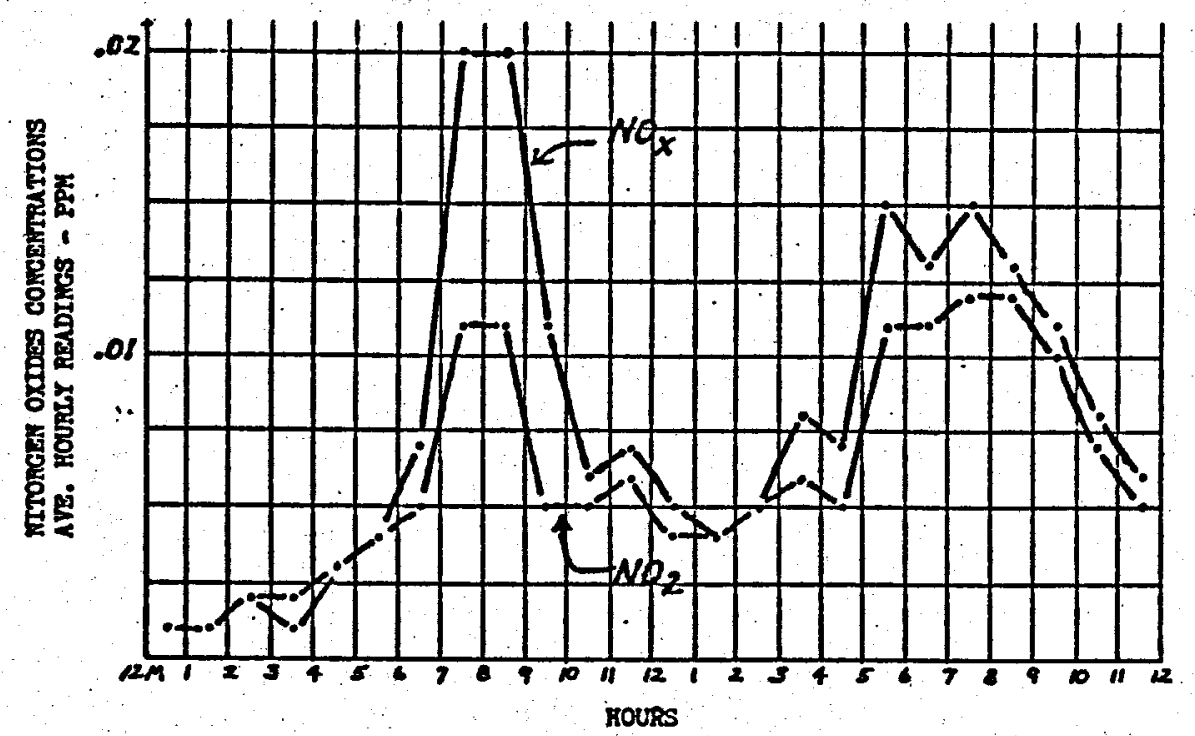

Figure 4 Maximum Hourly Average: $0.08 \mathrm{ppm} .\left(\mathrm{NO}_{\mathrm{x}}\right) ; 0.05 \mathrm{ppm}\left(\mathrm{NO}_{2}\right)$ Average of Maximum Hourly Averagest $0.03 \mathrm{ppm}\left(\mathrm{NO}_{x}\right)_{3} 0.02 \mathrm{ppm}\left(\mathrm{NO}_{2}\right)$.

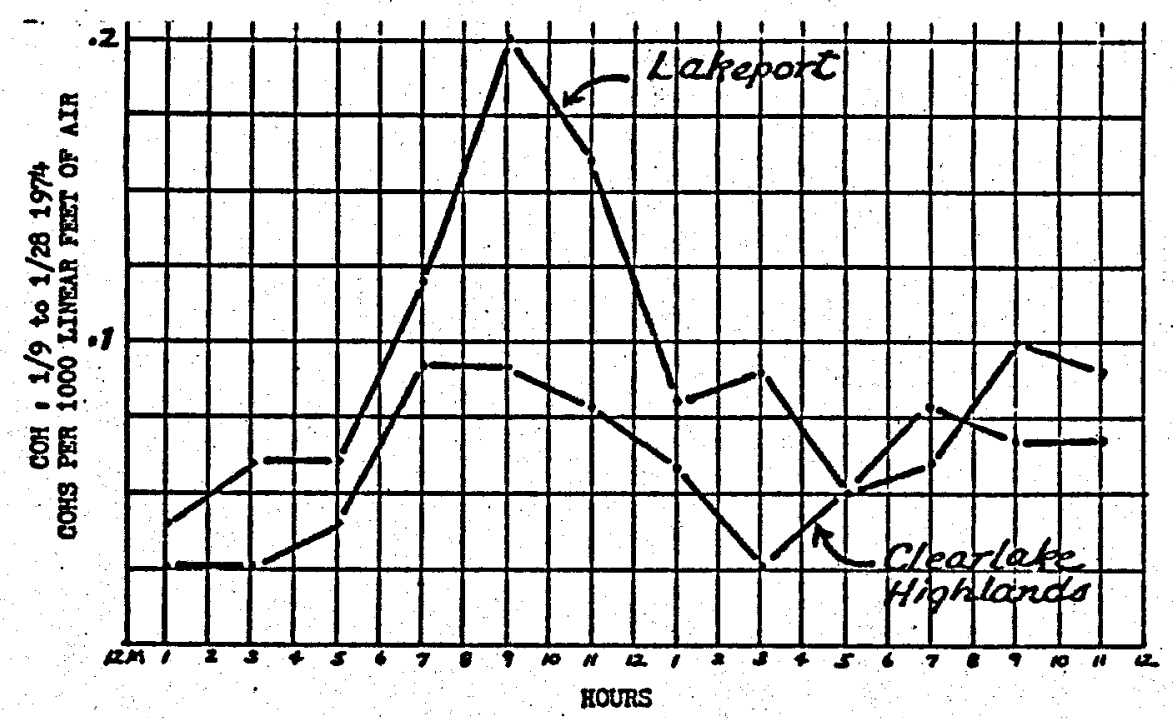

Figure 5 Maximum Hourly Average 1.2 (Lakeport); 0.4 (Clearlake Highlands) Average of M.H. Averagesi 0.3 and 0.2 respectively. 


\section{Environmental Consultants}

Fredericksen Engineering conducted a 24-hour analysis of background air quality at Borax Lake on February 12, 1976. The parameters monitored were those listed by the Lake County Air Pollution Control District for testing vaporphase emissions from geothermal wells. Monitoring results for the 24-hour of record are tabulated in Table 5 . Figure 6 shows the sampling sites in relation to Borax Lake.

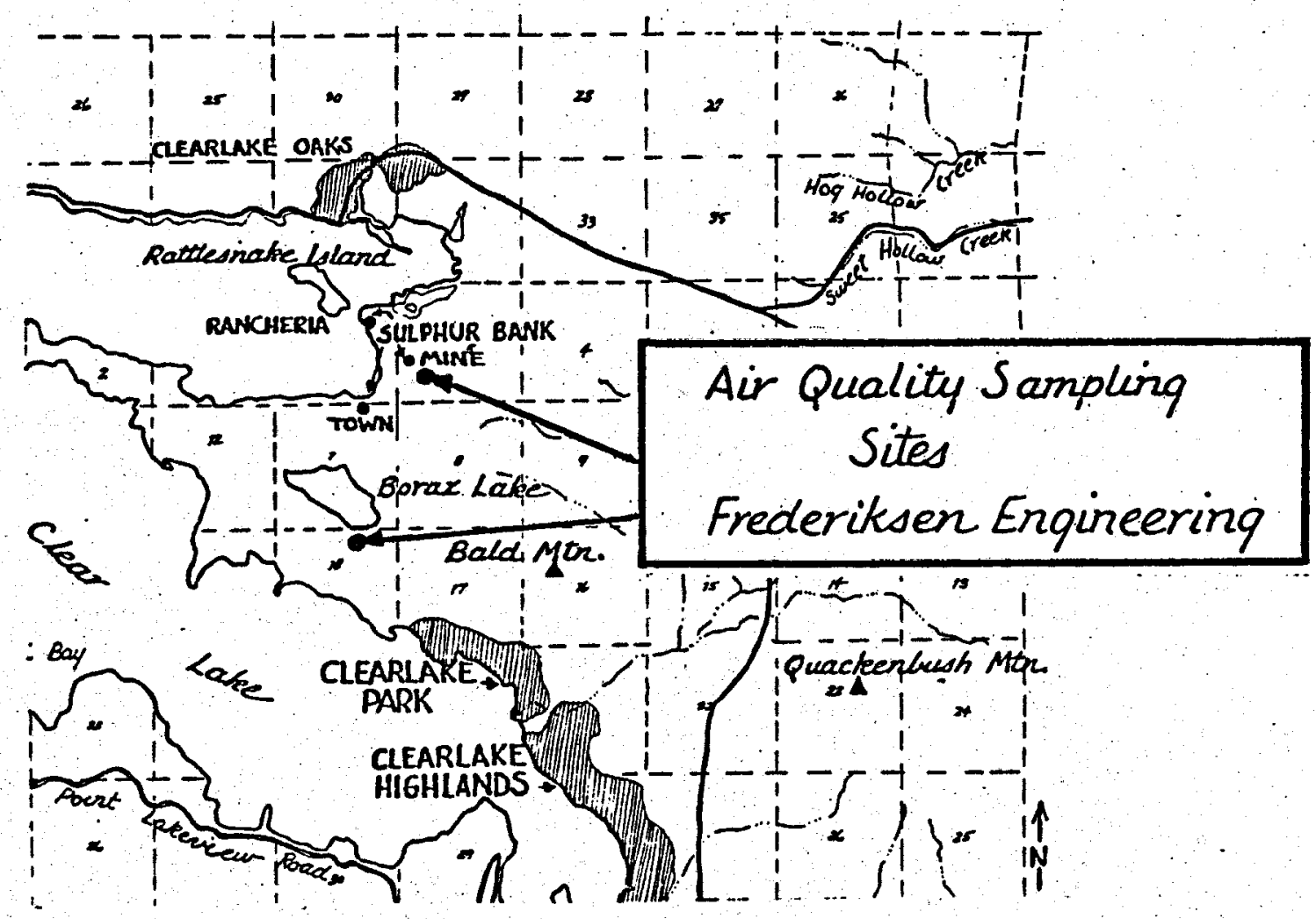

Figure 6. The relation of air quality sampling sites chosen by Fredericksen Engineering to Borax Lake, Clearlake Oaks, Clearlake Park, and Clearlaek Highlands. 
Table 5. Sampling Results from Fredricksen Engineering*

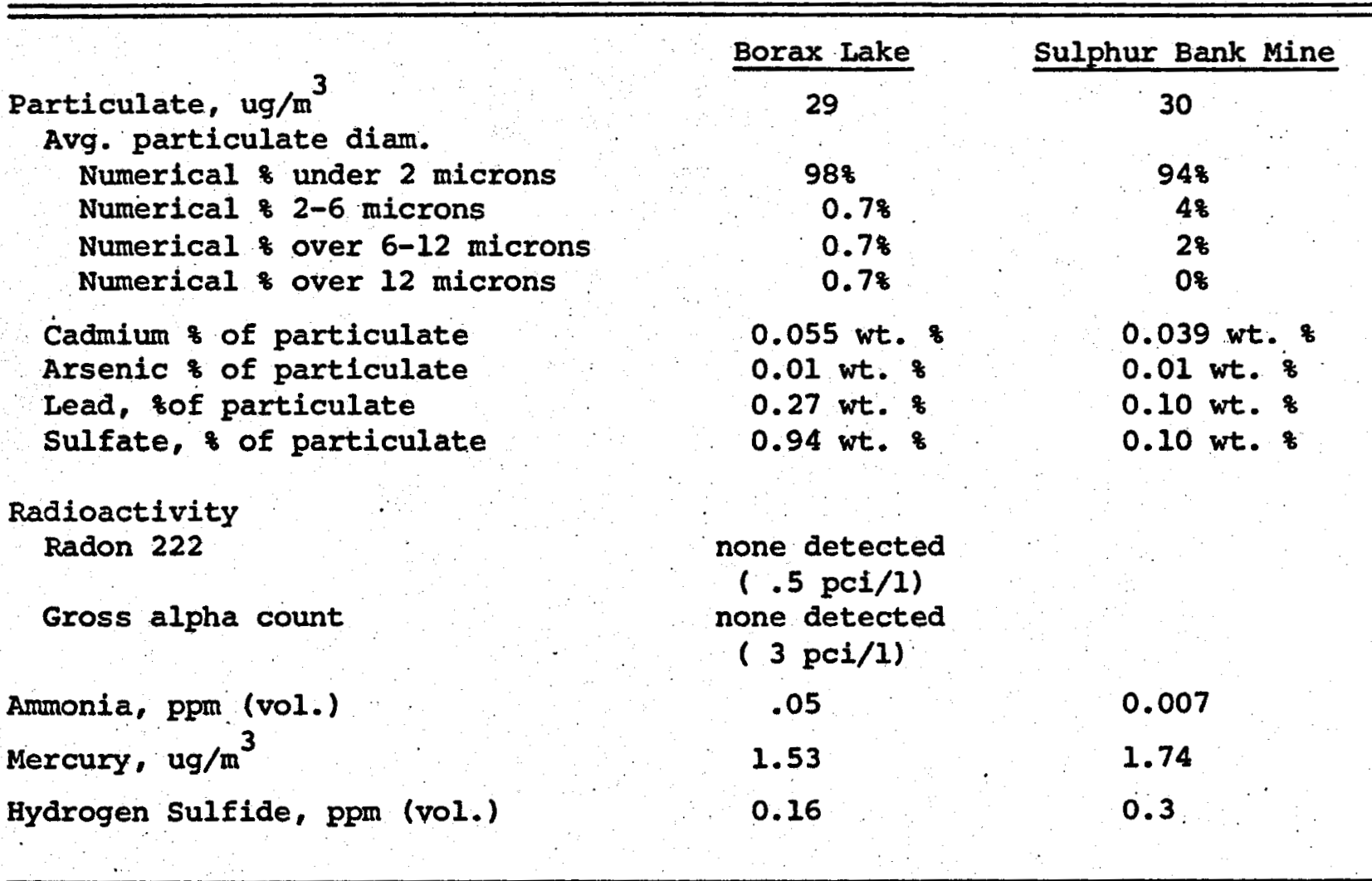

Weather Observations During Sampling Period Time Borax Lake

Sulphur Bank Mine

12:01 a.m. - 11:30 a.m. clear, calm; then cloudy and very light rain; then partly cloudy

11:30 a.m. - 1:40 p.m.

NW wind $5 \mathrm{mph}$; partly cloudy. $62^{\circ} \mathrm{F}$ dry bulb, $56^{\circ} \mathrm{F}$ wet bulb

1:40 p.m. - 3:25 p.m.

NW wind $13 \mathrm{mph}$; fair $67^{\circ} \mathrm{F}$ dry bulb, $56^{\circ} \mathrm{F}$ wet bulb winds $2 \mathrm{mph} ; 65^{\circ} \mathrm{F}$ NW wind 4 mph; fair $66^{\circ} \mathrm{F}$ dry bulb, $56^{\circ} \mathrm{F}$ wet bulb

4:09 p.m. $-6: 10$ p.m. NW wind $6.5 \mathrm{mph}$; fair $64^{\circ} \mathrm{F}-58^{\circ} \mathrm{F}$ dry bulb

* Sampling procedures are described in Appendix II. 


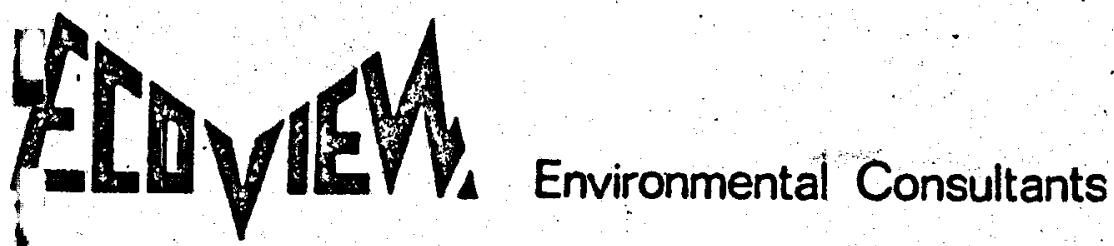

TABLE 6

SULFUR ANALYSIS SUMAYRY

$\frac{\text { September } 1976}{\text { Month }} \quad \frac{\text { LCAPCD }}{\text { AGENCY }} \quad \frac{\text { site } 17606}{\text { Date Released }}$

\begin{tabular}{|c|c|c|c|c|c|c|c|}
\hline Day & $\begin{array}{l}\text { Time of Highest } \\
\text { Hour Average }\end{array}$ & $\begin{array}{l}\text { ppb } \\
\mathrm{Er} .\end{array}$ & $\begin{array}{l}\text { Hlghest } \\
\text { Average }\end{array}$ & $\begin{array}{l}\text { Wind } \\
\text { Direct. }\end{array}$ & $\begin{array}{l}\text { Find } \\
\text { Rus }\end{array}$ & Temp. & R $\mathrm{H}$ \\
\hline 1 & 0100 & & $10 x$ & 050 & 0.9 & 62 & \\
\hline 2 & 0100 & & $10 x$ & 330 & 1.5 & 66 & \\
\hline 3 & 2300 & & 11 & 045 & 0.8 & 59 & \\
\hline 4 & 1400 & & 10 & 280 & 5.50 & 92 & \\
\hline 5 & 0100 & & $10 \times$ & 240 & 0.9 & 60 & \\
\hline 6 & 0100 & & io $x$ & 330 & 5.7 & 63 & \\
\hline 7 & 0100 & & $10 \times$ & 090 & 1.5 & 54 & \\
\hline 8 & 0100 & & $10 x$ & 130 & 1.1 & 48 & \\
\hline 9 & 0100 & & $10 x$ & 010 & 0.8 & 52 & \\
\hline 10 & 0100 & & $10 x$ & 255 & 0.8 & 57 & \\
\hline 11 & 0100 & & $10 \times$ & 315 & 0.2 & 59 & \\
\hline 12 & 0100 & & $10 x$ & 140 & 0.6 & 40 & \\
\hline 13 & 0100 & & $10 x$ & 320 & 0.6 & 50 & \\
\hline 15 & 1800 & & 12 & 230 & 2.8 & 62 & \\
\hline 16 & 0100 & & $10 x$ & 240 & 0.3 & 50 & \\
\hline 17 & 0100 & & $10 x$ & 160 & 0.2 & 46 & \\
\hline 18 & 0100 & & $10 \times$ & 350 & 0.9 & 49 & \\
\hline 19 & 0100 & & $10 \times$ & 075 & 0.5 & 48 & \\
\hline 20 & 1930 & & 13 & 285 & 6.1 & 66 & \\
\hline 21 & 1500 & & 11 & 330 & 8.8 & 78 & \\
\hline 22 & 1200 & & 12 & 280 & 3.6 & 75 & \\
\hline 23 & 1000 & & 10 & 220 & 2.7 & 66 & \\
\hline 24 & 1200 & & $10 x$ & 220 & 2.6 & 82 & \\
\hline 25 & 1200 & & $10 x$ & 240 & 3.6 & 79 & \\
\hline 26 & 1200 & & $10 x$ & 135 & 3.3 & 73 & \\
\hline 27 & 1200 & & $10 x$ & 180 & 2.1 & 59. & \\
\hline 28 & 1200 & & $10 \times$ & 210 & 2.0 & 59 & \\
\hline 29 & 1700 & & $10 \times$ & 120 & 2.0 & 62 & \\
\hline 30 & 1200 & & $10 \times$ & 300 & 8.5 & 72 & \\
\hline
\end{tabular}

number of days exceeding $30 \mathrm{ppb}$

0

of days exceeding $30 \mathrm{ppb}$

$x=10.3$

Total Monthly Average

10.3 


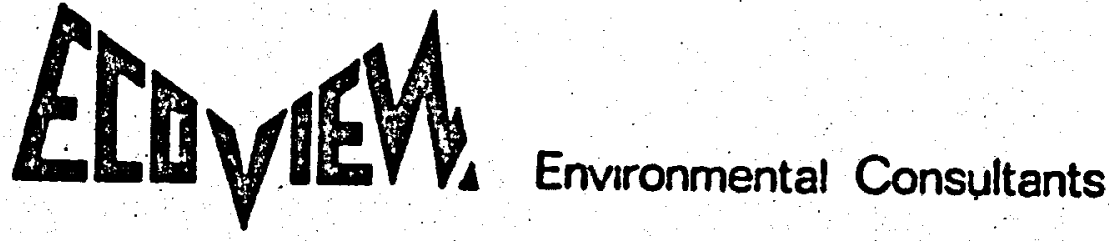

TABLE 7

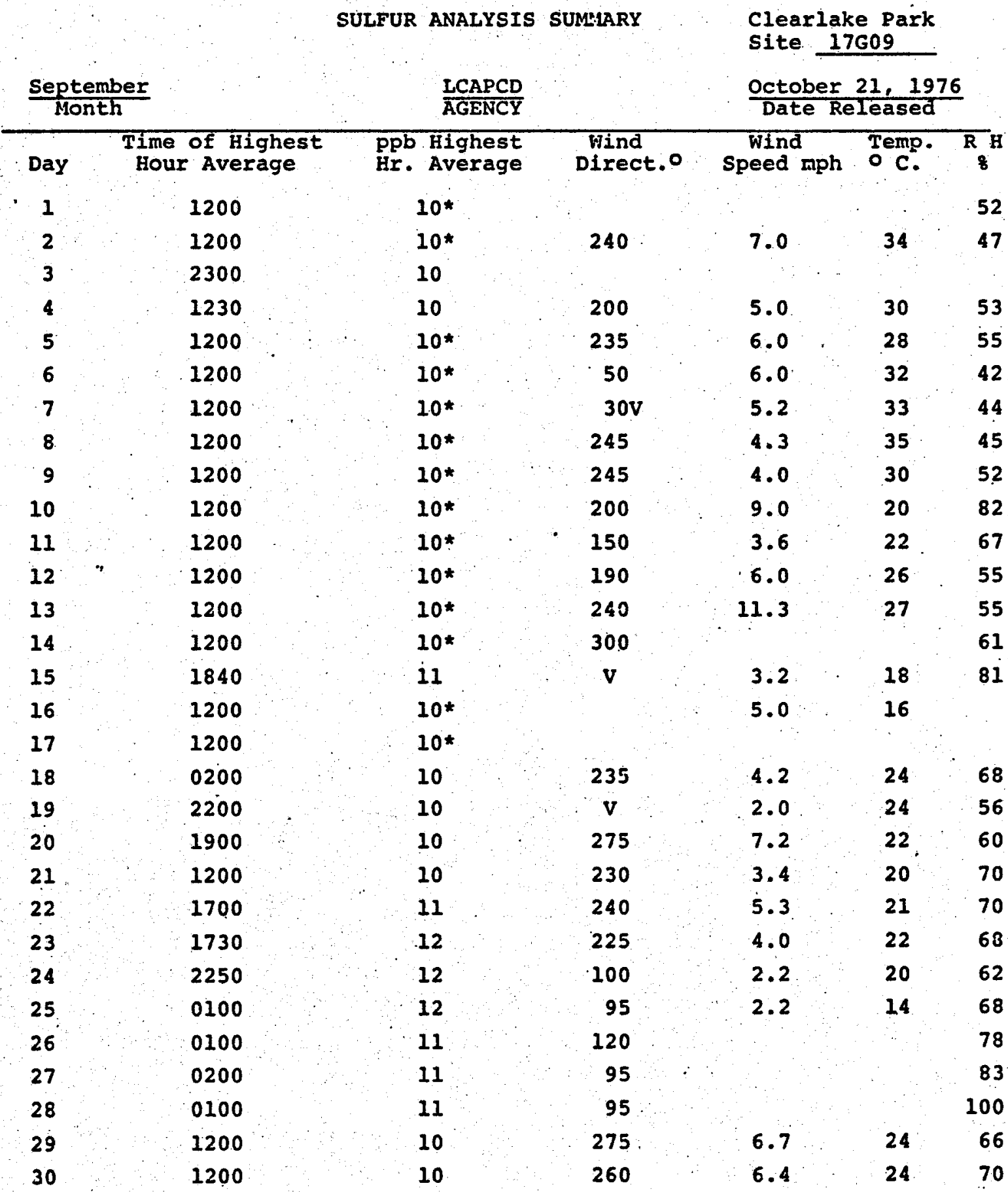

Number of days exceeding $30 \mathrm{ppb}$

$\bar{x}=10.4$
8. of days exceeding $30 \mathrm{ppb}$

Total monthly average $10.4 \mathrm{ppb}$ 
In response to Phillips Petroleum Company's proposal to arill an exploratory geothermal well at Borax Lake, the Lake County Air Pollution Control District (IACPCK) conducted a 60-day hydrogen sulfide $\left(\mathrm{H}_{2} \mathrm{~S}\right)$ monitoring project at the site in the fall of 1976. The monitoring results (Tables 6 and 7) indicate that $\mathrm{H}_{2} \mathrm{~S}$ is present in the ambient air at, levels consistently below the California ambient air standard of 30 parts per billion ( $p p b$ ) averaged over one hour.

Effects of nonelectrical uses on air auality

The methods of using hot water for nonelectrical uses involve a completely closed system until the heat is almost completely extracted. If water is not to be reclaimed then it should be reinjected if above 7 to $10 \mathrm{ppm}$ of boron. If water recluation is proposed then, the $\mathrm{H}_{2} \mathrm{~S}$ volumes need to be determined. In the event $\mathrm{H}_{2} \mathrm{~s}$ cannot be utilized in the associated processes, it should be scrubbed if the level

odors from cattle and other livestock could be a serious nuisance if conventional feed lot systems are used. Proper cascade geothermal operations can be integrated to reduce or eliminate their problem to acceptable levels.

Dust and particulate matter associated with feed lot operations can also contribute to nuisance levels if not controlled. Under the same use operations that control odors the dust problem should also be eliminated. 
III. THE WATER RESOURCE - STATUS AND QUALITY

\section{Hydrology}

High Valley is a nearly closed, somewhat isolated basin lying immediately north of clearlake Oaks, It consists of a flat or gently sloping alluvial plain about three miles long and one mile in average width (about 2000 acres). The total drainage area is about 12 square miles. The central alluvial area is approximately 400 feet above the level of clear Lake. Much of the alluvial plain is cultivated and dry-farmed, grain being the principal crop.

Short, steep intermittent creeks drain the surrounding hillsides, most of them terminating within the alluvial plain. In winter, when there has been enough rain, the water will form pools on the plain and flow in shallow channels to the head of schindler Creek, an intermittent creek, then drain into clear Iake near Clearlake oaks. Some of the water remains on the plain, particularly at the extreme eastern end of the valley, forming temporary swamps.

The California Department of Water Resources reports that average yield from wells in the valley is 100 gallons per minute (gpm), and the maximum yield is approximately $1000 \mathrm{gpm}$. Depth of the water bearing zone is 10 to 100 feet. Groundwater storage capacity in the basin is estimated at 9,000 acrefeet, with a usable capacity of about 900 acre-feet.* Known water quality problems are high concentrations of iron and boron.

* Source: Groundwater of the Lower Lake-Middletown Area, California. U. S. G. S. Water-Supply Paper 1297, Upson and Kunkel, 1955. 


\section{Environmental Consultants}

The Borax Lake Basin, with the exception of the southern extremity, is a closed drainage basin. No major named streams occur within the basin; however, a large number of short, steep gradient, ephemeral streams drain into Borax Lake from headwaters situated along the ridge system bounding the basin. (See Figure 7 Area run-off is characterized as storm events, with minimal interception or retention storage. Hydrograph curves rise steeply and peak sharply. The basin drains an area of approximately $6.5 \mathrm{~km}^{2}$.

\section{Water Quality}

Iittle is known about the groundwater in the Borax Lake basin. The Quaternary lake deposits are believed to be water-saturated at shallow depth throughout the study area. Ground seepage seems to play a role in reducing the level of Borax Lake each year, but no specific data is available to substantiate this.

A preliminary analysis of wells and springs (Table 8 ) in the project vicinity was performed during December of 1975. Five sites near Borax Lake were sampled: two wells approximately $3.7 \mathrm{~km}$ east of the proposed Phillips Petroleum Company's well site, and three springs located along the sulphur Bank ridge.

The few springs within the study area are high in mineral content. Water chemistry for all species analyzed appears to be highly variable. The greatest departure from normal water quality conditions was noted at sample \#5, a spring adjacent to the Sulphur Bank Mine. These waters are acidic and have high concentrations of sulfate, ammonium, sodium, chloride and boron. The abnormal chemical conditions are probably related to mining activities in this vicinity. 


\section{Environmental Consultants}

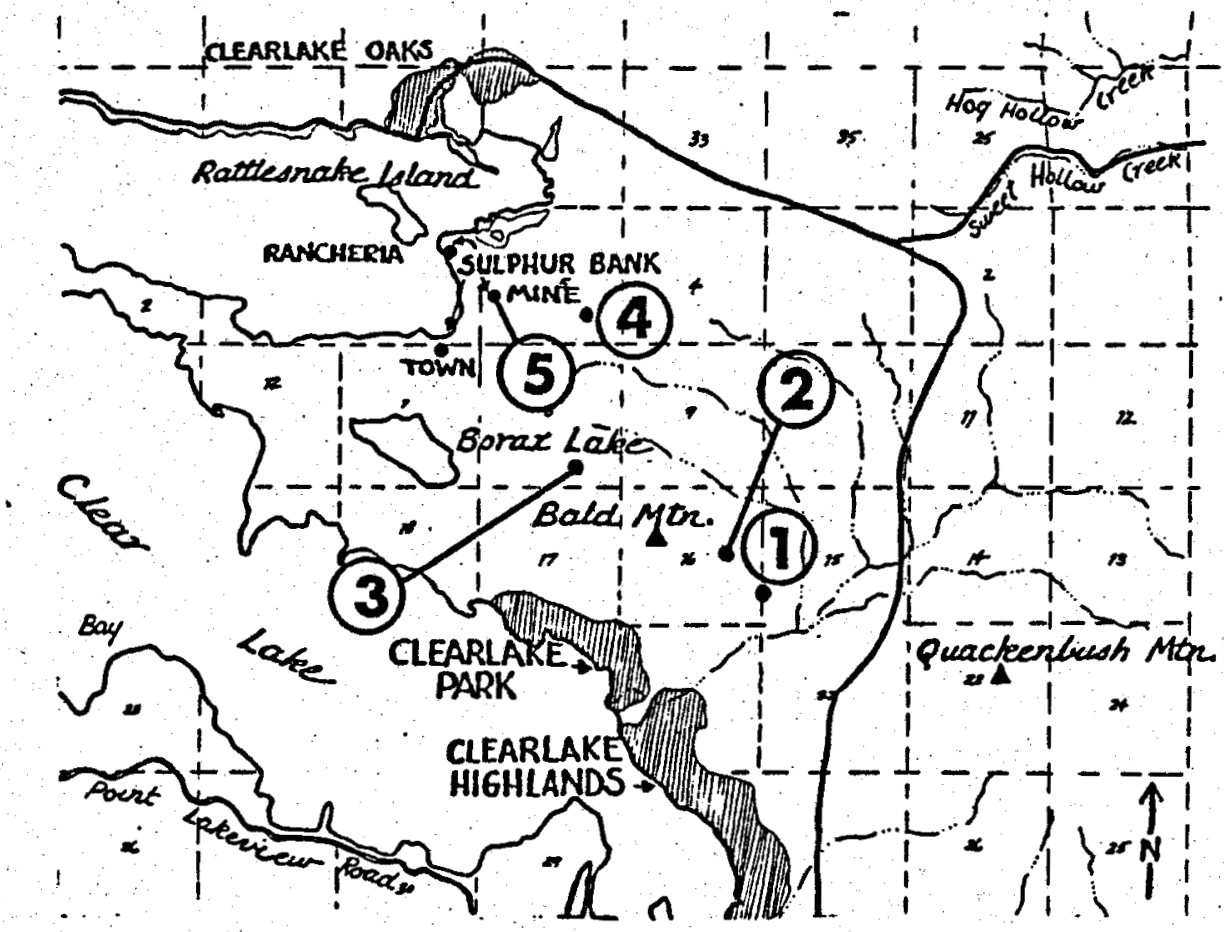

Figure 8. The location of the springs and wells sampled by Phillips 011 Co. Sites 1 and 2 are wells; sites 3,4 , and 5 springs.

TABLE 8

WATER SAMPLE RESULTS

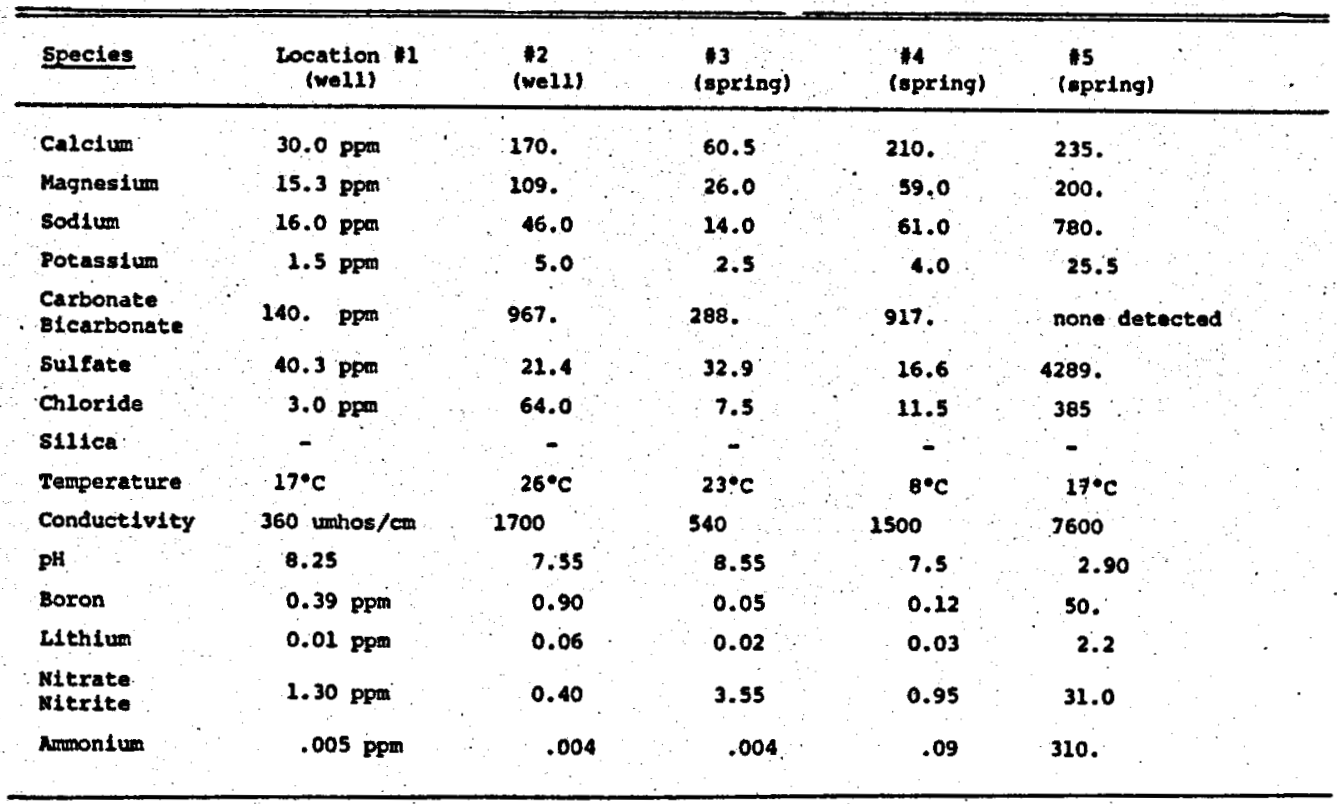

Source , Phtlilips o1l Go. 
Iittle is known about High Valley's water quality. However, water analysis is available from two wells in the valley (Table 9). This work was done by the California Department of Water Resources.

\section{Limnology of Borax Iake}

Although of small size, Borax Lake is significantly different from Clear Lake. Its physical characteristics are presented in Figure 9 and Table 10.

Water level changes closely correlated with seasonal precipitation characterize Borax Iake. In 1961 - 1962, when rainfall was slightly above normal, Wetzel (1963) recorded the low level in October, 1961 and the high in March, 1962. The lake's area and volume varied in a similar manner. Evaporation and presumably ground seepage play a large role in reducing the level of the lake each year, since there is no surface outflow.

Over most of the basin, the shore zone is affected only slightly by inundation of rising water levels in the winter due to the moderate slope of the shore area. The lateral increase in shore area may be between 3 and $7 \mathrm{~m}$, which results in a threefold increase in the littoral area available for periphyton (attached algae, etc.) colonization.

Figure 10 illustrates the yearly cycle of incident solar radiation and temperature. The light curve is characteristic of this area in California with high radiation during clear summer days and periods of lower radiation and some cloudiness in winter. 


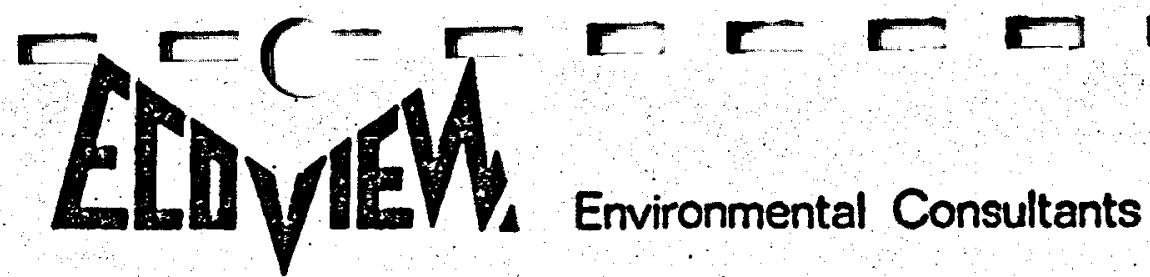

TABLE 9

WATER CHARACTERISTICS OF HIGH VALLEY WELLS

\begin{tabular}{|c|c|c|c|c|c|c|c|c|c|c|c|c|c|c|c|}
\hline We11 & Temp & $\mathrm{pH}$ & EC & $\mathrm{CA}$ & MG & NA & $\mathbf{K}$ & $\mathrm{CO}_{3}$ & $\mathrm{HCO}_{3}$ & $\mathrm{SO}_{4}$ & CL & $\mathrm{NO}_{3}$ & B & $\mathbf{F}$ & TDS \\
\hline $\begin{array}{l}14 \mathrm{~N} / 08 \mathrm{~W}- \\
23 \mathrm{KOI}\end{array}$ & $66^{\circ} \mathrm{F}$ & 6.5 & 170 & 12 & 8.3 & 12 & & 0 & 86 & 9.4 & $4 \cdot 3$ & 2.5 & 0 & - & 114 \\
\hline $\begin{array}{l}4 N / 08 W- \\
4 B 02\end{array}$ & $65^{\circ} \mathrm{F}$ & 6.1 & 720 & 43 & 55 & 53 & 1.3 & 0 & 409 & 60 & 23 & 1.0 & .50 & - & 434 \\
\hline
\end{tabular}

$\mathrm{EC}=$ Electrical conductance in microm at $25^{\circ} \mathrm{C}$

TDS $=$ Total Dissolved Solids at $180^{\circ} \mathrm{C}$

TH = Total Hardness

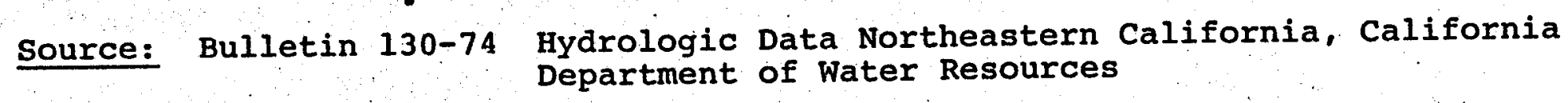




\section{Environmental Consultants}

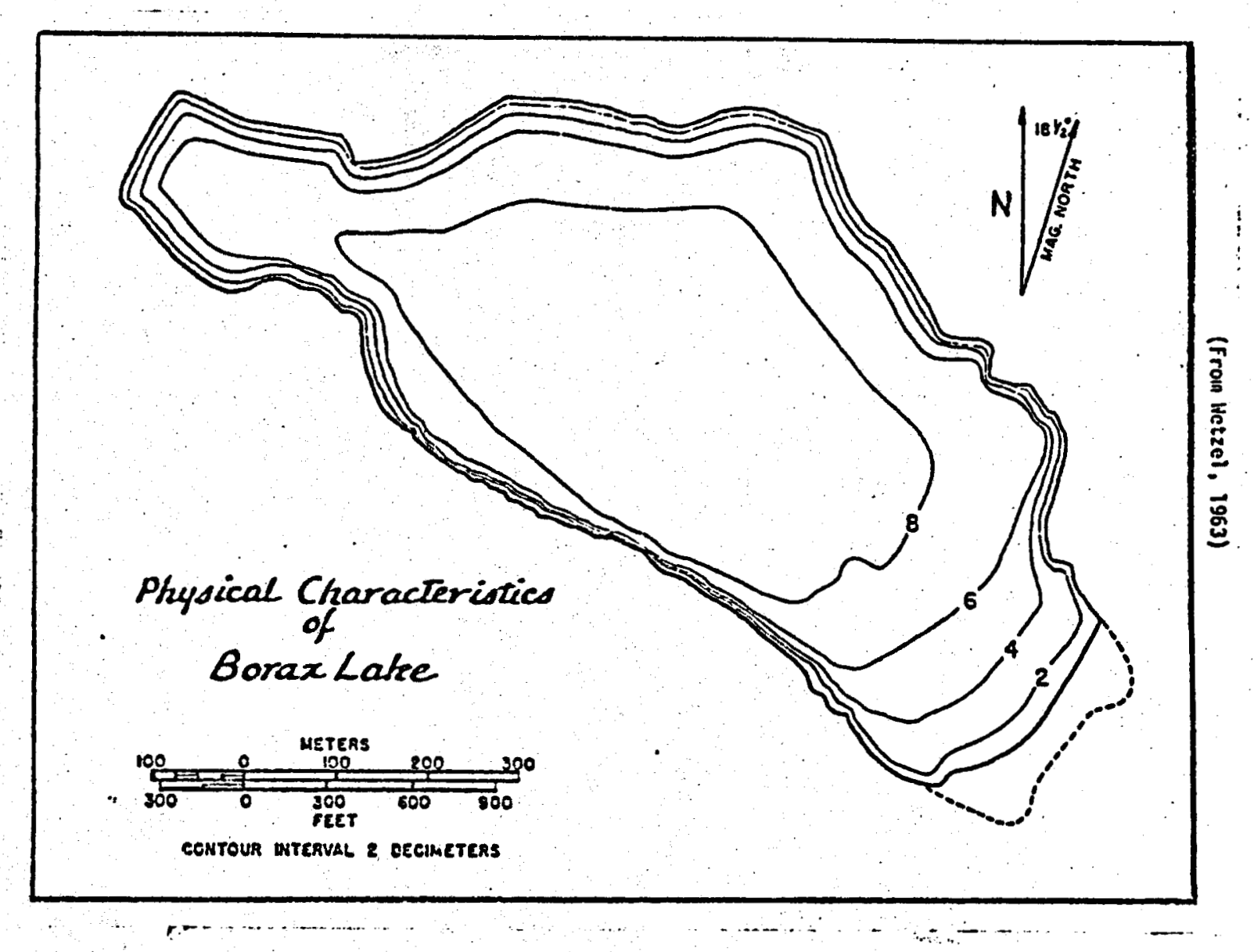

Figure 2. Diagram showing confirmation and depth contours of Borax Lake.

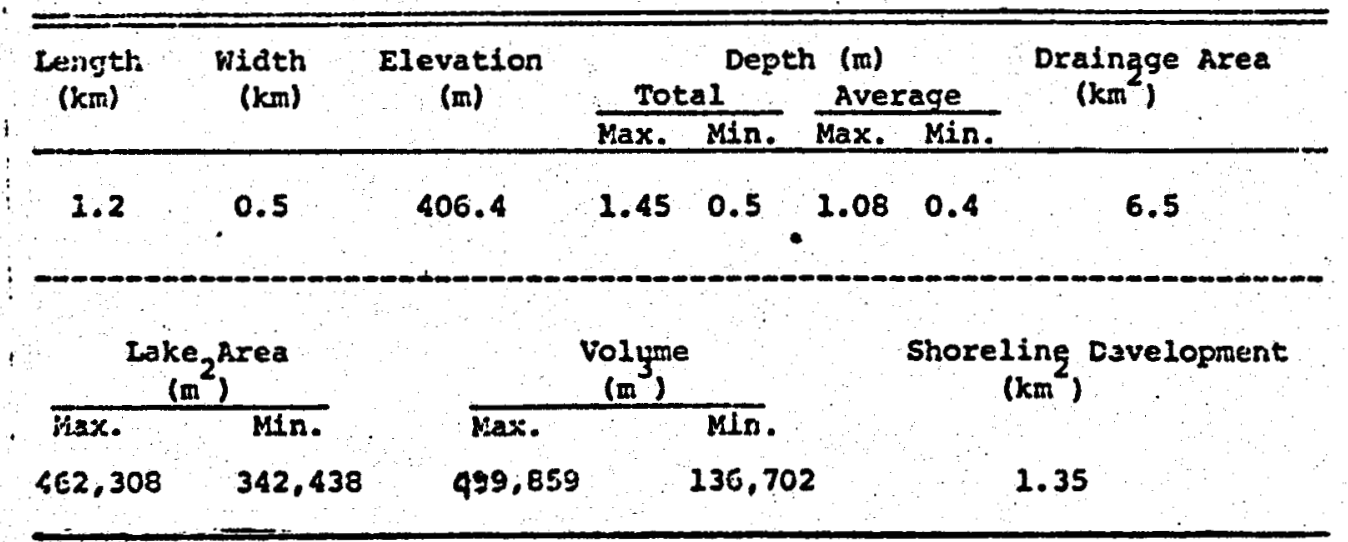

Table 10. Limnological characteristics of Borax Lake, Lake County, California, Data extracted from Wetzel, 1963 . 
Wetzel (1963) postulates that light may be an important limiting factor to algae and water weed growth in the lake, limiting aquatic growth in the winter because it is so low, and inhibiting it in summer when it is extremely high.

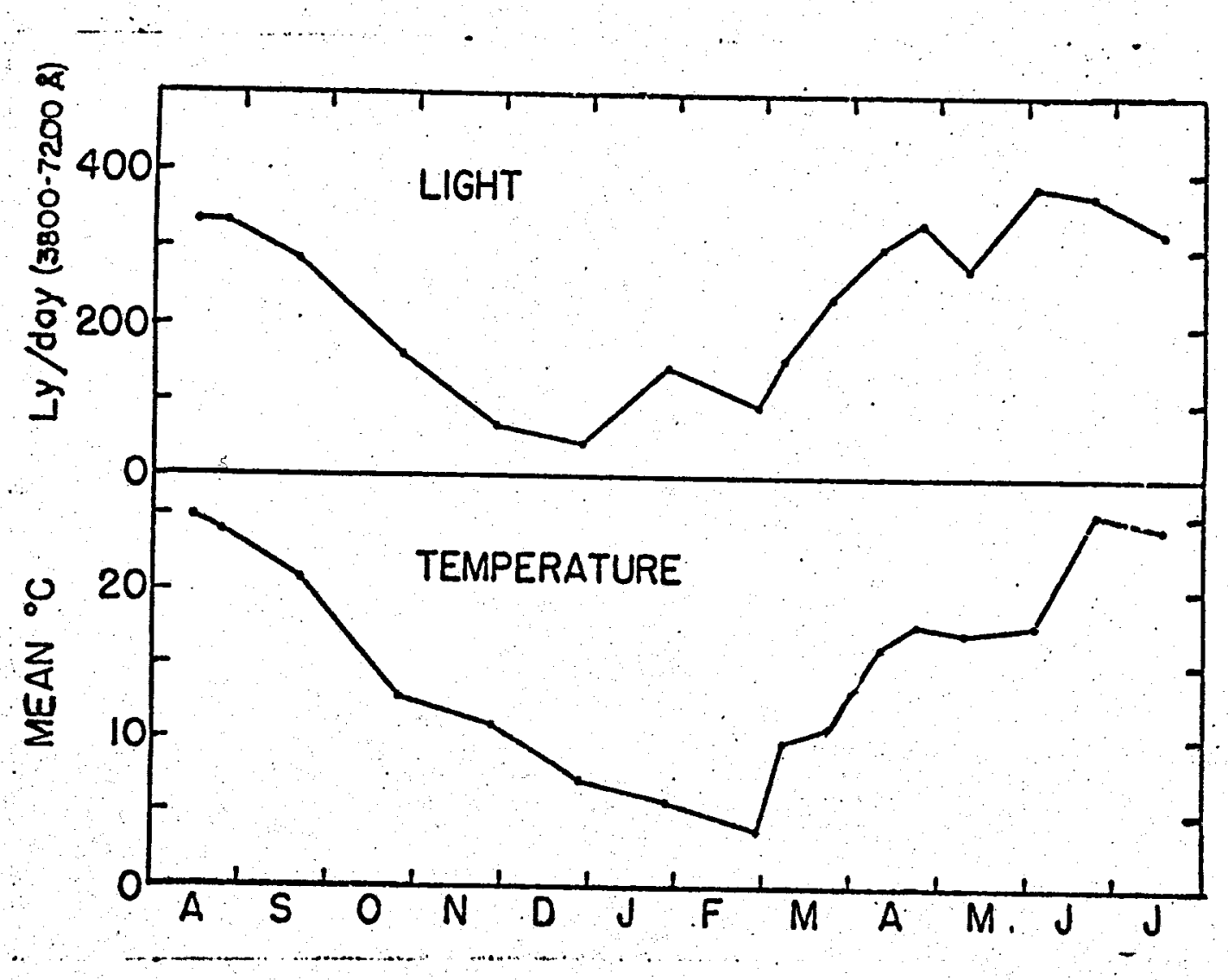

Figure 10. The annual cycle of solar radiation and water temperature. Water temperature corresponds closely to solar radiation, but is also influenced by other factors. Water temperature fluctuations depend not only on solar. radiation, but also on varying water level caused by precipitation, evaporation, and wind mixing. Water temperatures of 1961-62 ranged between $25^{\circ} \mathrm{C}$. in June through August, to $4^{\circ} \mathrm{C}$. in February. This appears to be about average for California lakes. The annual average water. temperature based on these figures appears to be about $16^{\circ} \mathrm{C}$. 


\section{Environmental Consultants}

Due to shallowness and frequent winds, Borax Lake never stratified, $i . e .$, a warm surface layer lying over cold water below (Wetzel, 1963). No record indicates that the lake has ever frozen over. The depth of water transparency measured with a standard Secchi disc was between $0.2 \mathrm{~m}$ in winter and $1.1 \mathrm{~m}$ in summer. The shallow transparency was in large part due to prevalent turbidity. Shallowness, the soft unconsolidated sediments, and frequent strong winds result in an almost continual high turbidity, reaching a peak in February and low in April of 1962

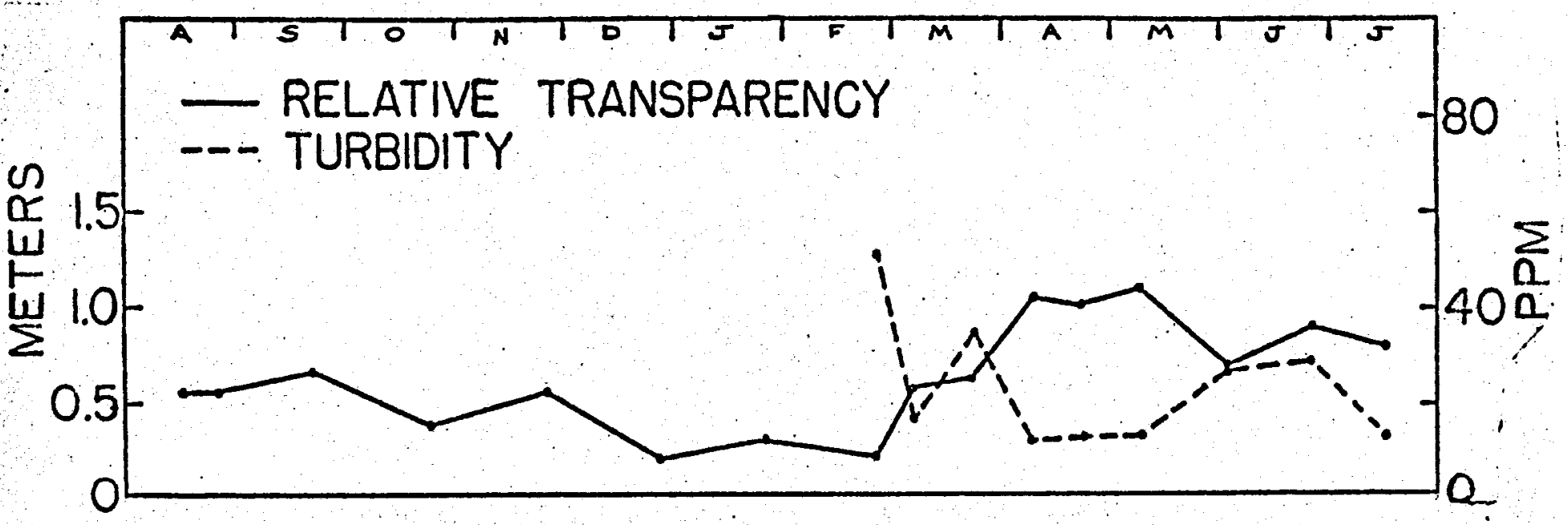

Figure 11. Annual transparency of Borax Lake, transparency increas two-fold as turbidity decreases in the spring and summer. Like other saline lakes of the world, Borax lake has large concentrations of both cations and anions which restrict the diversity of aquatic life. Table 11 lists the ranges and average values for the chemical characteristics of its surface waters.

In comparison with other saline lakes, Borax Lake has a very low ratio of $\mathrm{SO}_{4}$ ion $(.05-.17 \%)$ to $\mathrm{CO}_{3}(22-25 \%)$ and $\mathrm{Cl}(35-38 \%)$. The high $\mathrm{pH}$ values associated with the high alkalinity deviate only slightly throughout the year, even with the inflow of fresh rainwater and changes in lake volume and area. This indicates Borax Lake is strongly buffered. Buffer intensity, in this case the sum of the carbonate and borate components, controls the 


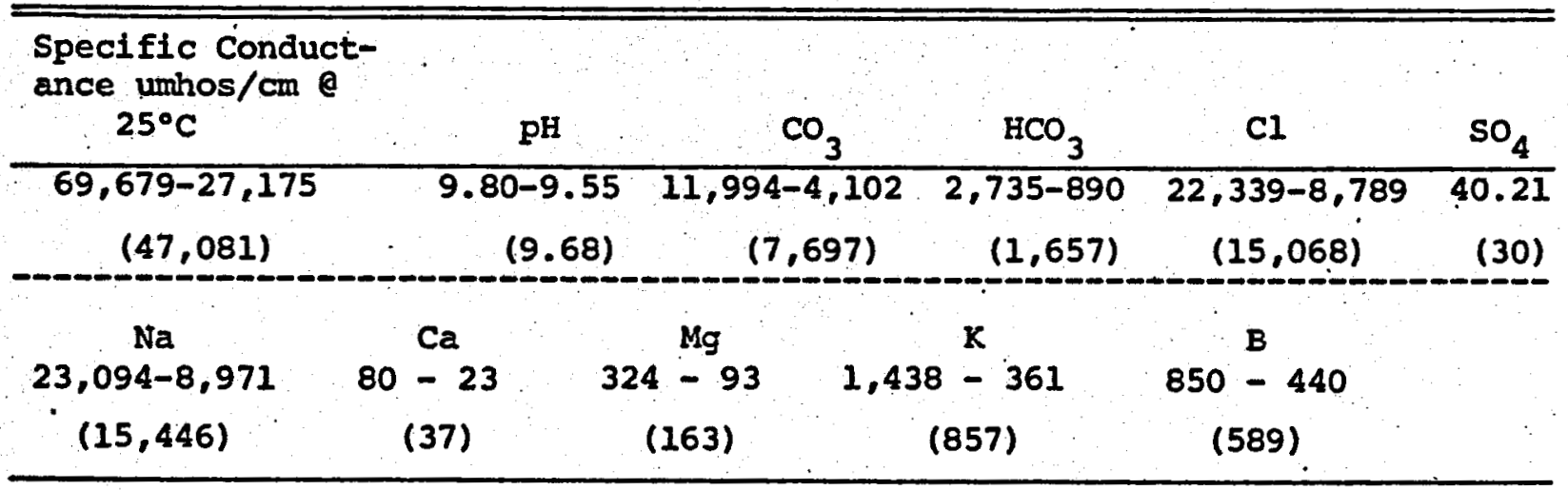

Table 11. Analysis of surface waters from Station $B$, Borax Lake, 1961 - 1962. Data revised from Wetzel (1963) and expressed as parts per million (ppm) . Averages are in parentheses.

magnitude of shifts in the $\mathrm{pH}$. The $\mathrm{pH}$ of Borax Lake will be maintained at its current value of 9.5, unless acids are introduced which eliminate carbonate ion from the system, thus destroying the buffering system.

$$
2 \mathrm{H}+\times \mathrm{CO}_{3}=\rightarrow \mathrm{CO}_{2} \uparrow+\mathrm{H}_{2} \mathrm{O}
$$

The sulfate-sulfide equilibrium characteristics of Borax Lake are determined to a large extent by the high concentration levels of the carbonate-borate buffering system. In -well aerated solutions, such as the surface waters of Borax Lake, sulfur species exist almost entirely as sulfate $\left(\mathrm{SO}_{4}{ }^{\prime}\right)$. other species, such as bisulfite. ( $\mathrm{HSO}_{4}^{-}$) and native sulfur (s), are present in minute quantities but they do not significantly affect the chemical characteristics of Borax Lake.

In poorly aerated solutions, $i . e .$, the upper layer of sediments, sulfur species exist primarily as hydrosulfide ion (HS) and to a lesser extent as sulfide ion $\left(S^{=}\right.$). A small conversion of $\mathrm{HS}^{-}$and $\mathrm{s}^{=}$to $\mathrm{SO}_{4}=$ takes place. This 
Environmental Consultants

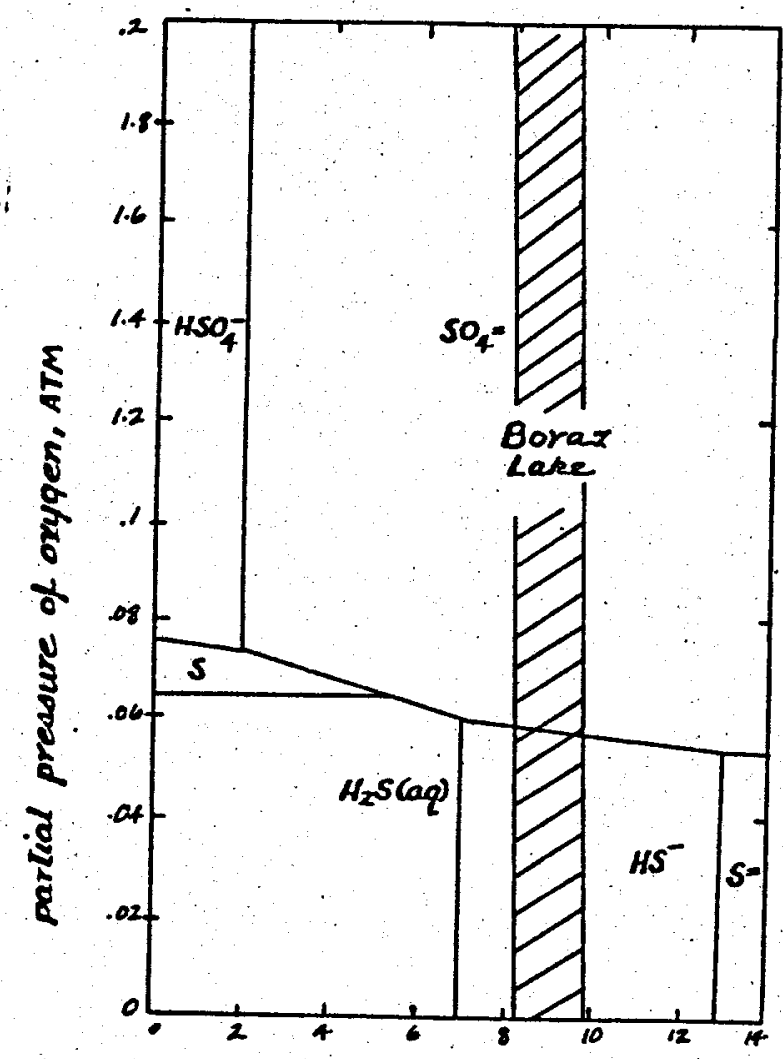

Figure 12, the fields of sulfur species ions.Over most of any one field, the designated species makes up more than 998 of the total sulfur in solution. Near any boundary line the concentration diminishes. The boundary line itself is drawn through points where the two species on either side have equal concentrations. This means that at $\mathrm{pH} 9.5$, the concentration of $S^{=}$in the HS field is finite but small. Sulfide ion, $s^{=}$, is never a major constituent of any. geologically important solution. However, its role in natural processes is important. Even though its concentration is minute compared to $\mathrm{HS}^{-}$and $\mathrm{H}_{2} \mathrm{~S}$, it is capable of precipitating many heavy metal ions as insoluble sulfides.

is the chemical interface at which equilibria between the major sulfur species at alkaline pH's are established and the equilibrium composition of the lake is established. At concentrations of atmospheric oxygen approaching zero, i.e., deeper sediments, the major sulfur species are still us $^{-}$ and $\mathbf{S}$. However, heavy metals concentrated as insoluble sulfides are the predominant regime. Atmosphexic oxygen is insufficient to permit conversion to sulfate. 
Environmental Consultants

The boundaries in Figure V-12 are calculated for equilibrium conditions. However, under natural conditions reduction of sulfate to sulfide is very slow. Normally, it is undetectable unless bacteria accelerate the conversion rate. For this reason, sulfate may have a transient lifetime even in strongly reducing solutions. This is presumably the reason for the smal1, but constant, concentration of sulfate observed in Borax Lake.

The reduction of sulfate to sulfide takes place when sulfate comes in contact with organic matter. The reaction depends upon the presence of anaerobic bacteria which utilize sulfate and organic hydrocarbons both as an energy and oxygen source.

$$
2 \mathrm{H}^{+}+\mathrm{SO}_{4}=\mathrm{CH}_{4} \frac{\text { anaerobic }}{\text { bacteria }} \mathrm{H}_{2} \mathrm{~S}+\mathrm{CO}_{2}+\mathrm{H}_{2} \mathrm{O}
$$

This reaction occurs with any organic material such as plant or animal residues, as well as, man-made effluents. It is likely to be the primary mechanism for the production of hydrogen sulfide from sulfate in Borax Lake.

The oxidation of hydrogen sulfide and native sulfur to sulfate in aqueous solution is also a slow reaction. This is in marked contrast to the relatively rapid oxidation of hydrogen sulfide to sulfur dioxide and sulfur trioxide in air.

Borax Lake also has one of the highest concentrations of boron in the world - $850 \mathrm{ppm}$. Boron is an important micronutrient for promoting plant growth, but it can also be an inhibitory and toxic substance if too concentrated in the environment. Wetzel (1963) performed a series of experiments to assess the effects of the high boron levels in Borax Lake. In situ and iaboratory bioassays indicated that the phytoplankton had a high tolerance to boron concentrations even greater than those 


\section{Environmental Consultants}

found in Borax Lake. Stimulation of growth was common in early spring when environmental concentrations were increasing. As the increase continued into summer, initial inhibitory responses were more pronounced, but the algae showed rapid physiological adaptability (Figure V-13). The macrophytes Elodea and Ceratophyllum appear to be stimulated by levels somewhat greater than environmental levels $(0.5-100 \mathrm{mg} / 1)$ in Borax Lake.

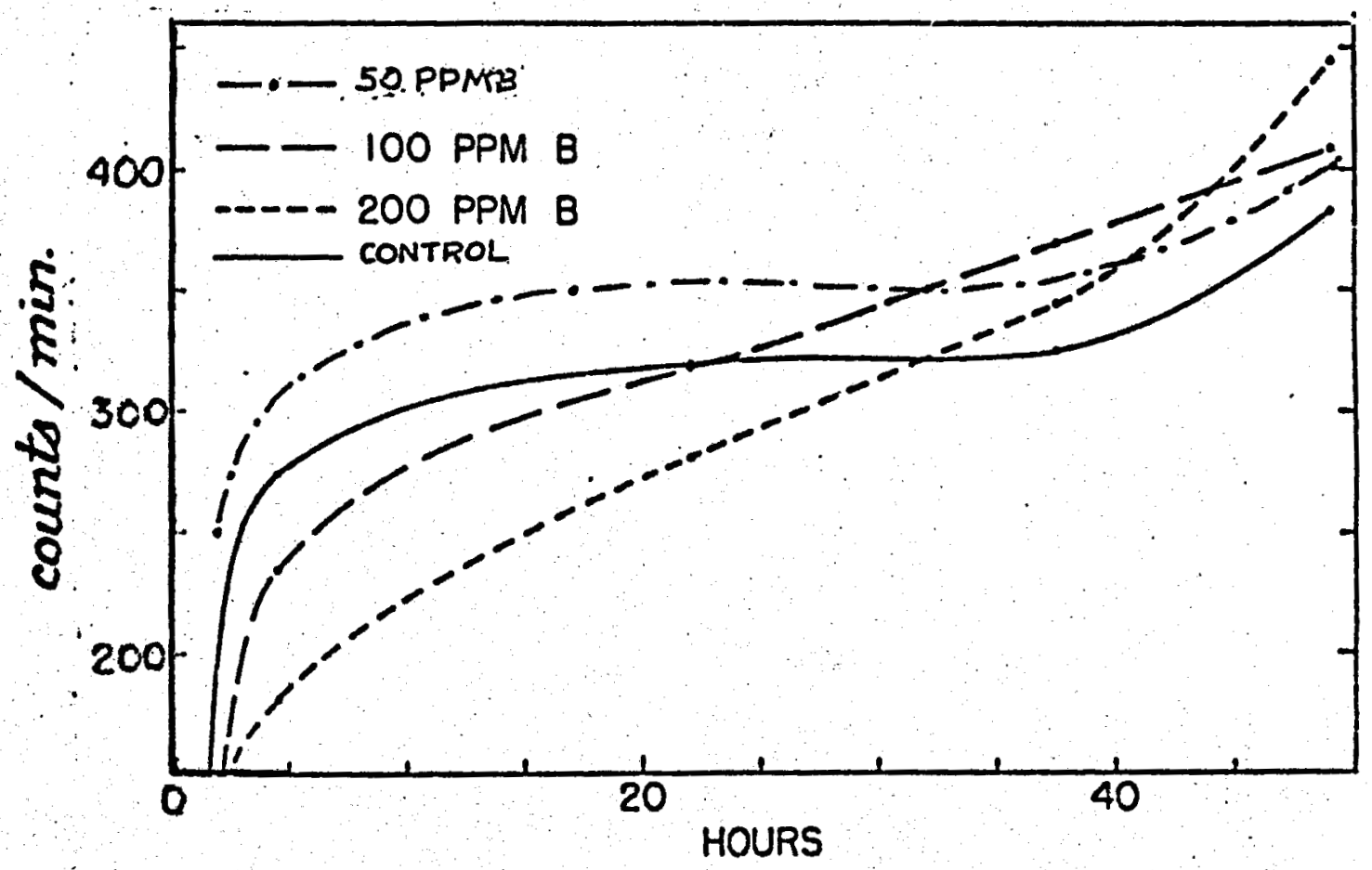

Figure 13. Algal phsiological adaptability to varying concentrations of boron. (Adapted from Wetzel, 1963.)

These stringent physical and chemical conditions of Borax Lake have imposed limitations on the diversity of flora and fauna. Total number of species is low, while quantitative abundance can be very high, depending upon the organism. This is graphicalys portrayed during the hot sumer months when insect swarms and decay of the aquatic vegetation along the receding shoreline are evident. 


\section{Environmental Consultants}

Wetzel (1963) makes no mention of the algae species which comprised the phytoplankton (floating algae). He listed the major periphyton forms (attached algae) as ctenocladius circinnatus, Coccohloris sp., and Oscillatoria sp. The first type is a green algae, and the latter two are blue-green algae. The aquatic macrophytes (weeds) include potomogeton crispus, Isotes brauni, Elodea canadensis and Ceratophyllum demersum. The major herbs and grasses include Ruppia maritima which circumscribe the shore, and the salt grass, Distichlis spicata, occurring above the water line.

Fauna is also limited to a few tolerant species. The zooplankton include the ciliate cladotricha sp... the red copepod Diaptomus sicilis which sometimes occurs in large swarms, the cladoceran Moina hutchinsoni, and the very abundant rotifer, Hexarthra sp. Insects are one of the predominant life forms here and the dipterans flies and gnats form huge swarms; they iine the shore up to a meter deep from the water's edge at some times of the year. These dipterans include Hydropyrus hians and Eulalia tumida. No native fish can tolerate the alkaline, saline water of this lake.

Primary production (i. e., the assimilation of $\mathrm{CO}_{2}$ to form sugars and starches) derived from attached and floating algae and submerged macrophytes in Borax Lake for a year's time, was high (Wetzel, 1963) compared to some of the more eutrophic lakes of the world including nearby clear lake (Table 12). This is not surprising given the difference in the ionic composition of its waters, and the large extent of its shore zone in relation to its almost nonexistent open water zone. When compared solely on an areal ( $\mathrm{mgc} / \mathrm{m}^{2} /$ day) basis, it appears that the periphyton (attached algae) production outweighs that of phytoplankton (free floating algae), and that macrophytes (water weeds) lagged behind the latter group. 


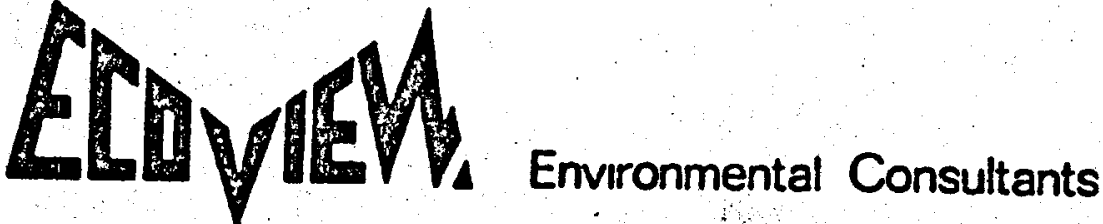

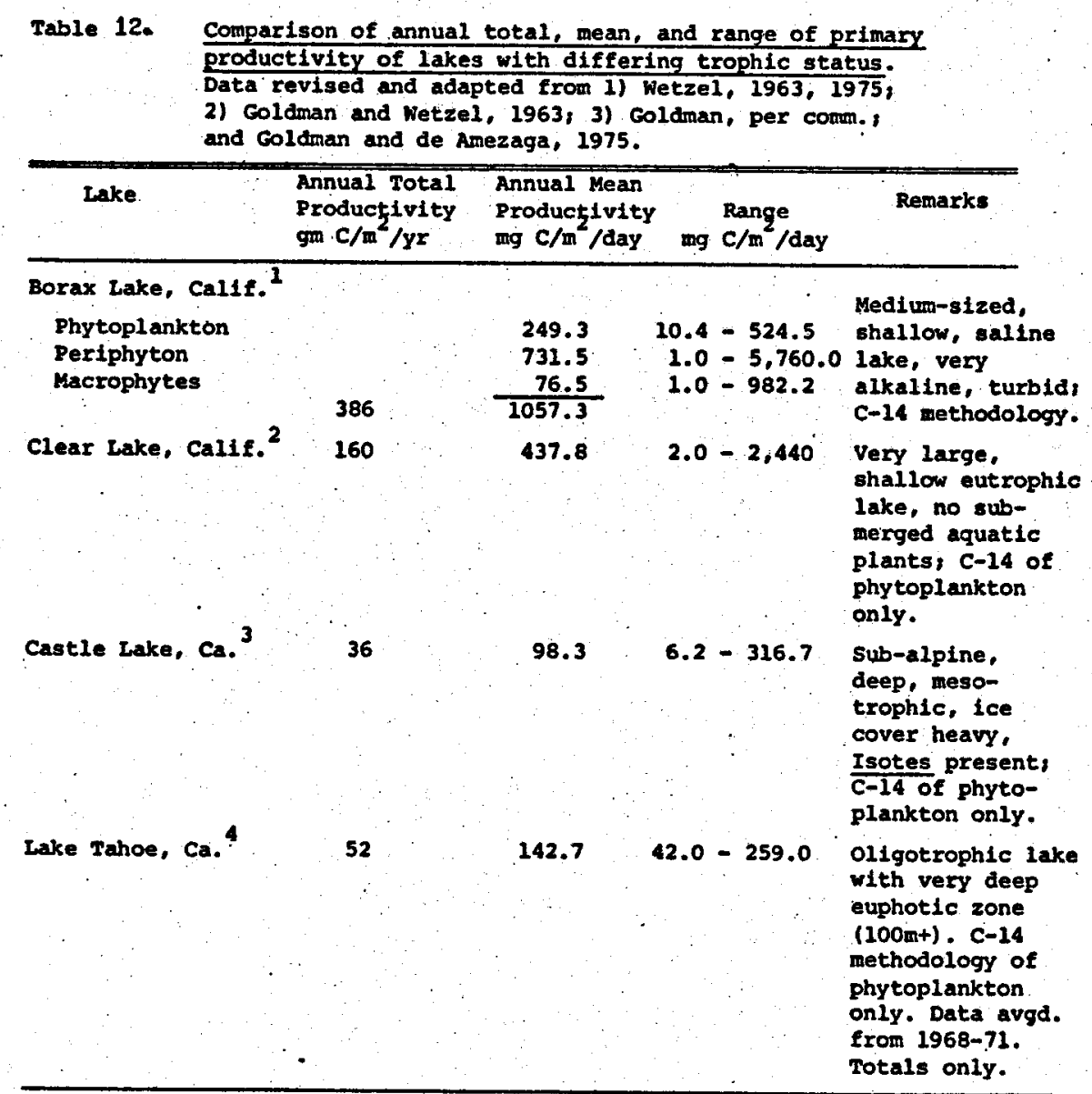

(It should be noted that the high totals for Lake Tahoe are due to the extreme depth of light penetration in its clear waters. A volumetric comparison would be more realistle for comparison of Tahoe to other lakes.)

Fluctuation in volume and water level (area) have a pronounced effect on the biota. When phytoplankton production is compared on a changing volume basis to that of the periphyton and macrophytes on a fluctuating areal distribution basis, a more realistic comparison of the contribution of each floral component to the total emerges. On an annual basis, phytoplankton productivity then becomes the most important. Periphyton assumes a secondary role, and macrophytes follow. The reason for this is partly because the phytoplankton continue growth, although low, throughout fall and winter. Periphyton growth ceases during January and February, and macrophytes exhibit 


\section{LCD VIM. Environmental Consultants}

a short but important period of growth in the spring (April June) (Figure 14). Apparently, the severe conditions imposed by the meteorological and hydrochemical environment on Ruppia restricts its growth to the few short spring months. In comparison, phytoplankton are able to adapt more quickly than macrophytes to changing conditions. For instance, phytoplankton greater than 10 microns in size dominate in the warm seasons and the ultraplankton $0.5-10$ microns are moxe prevalent in the winter.

C

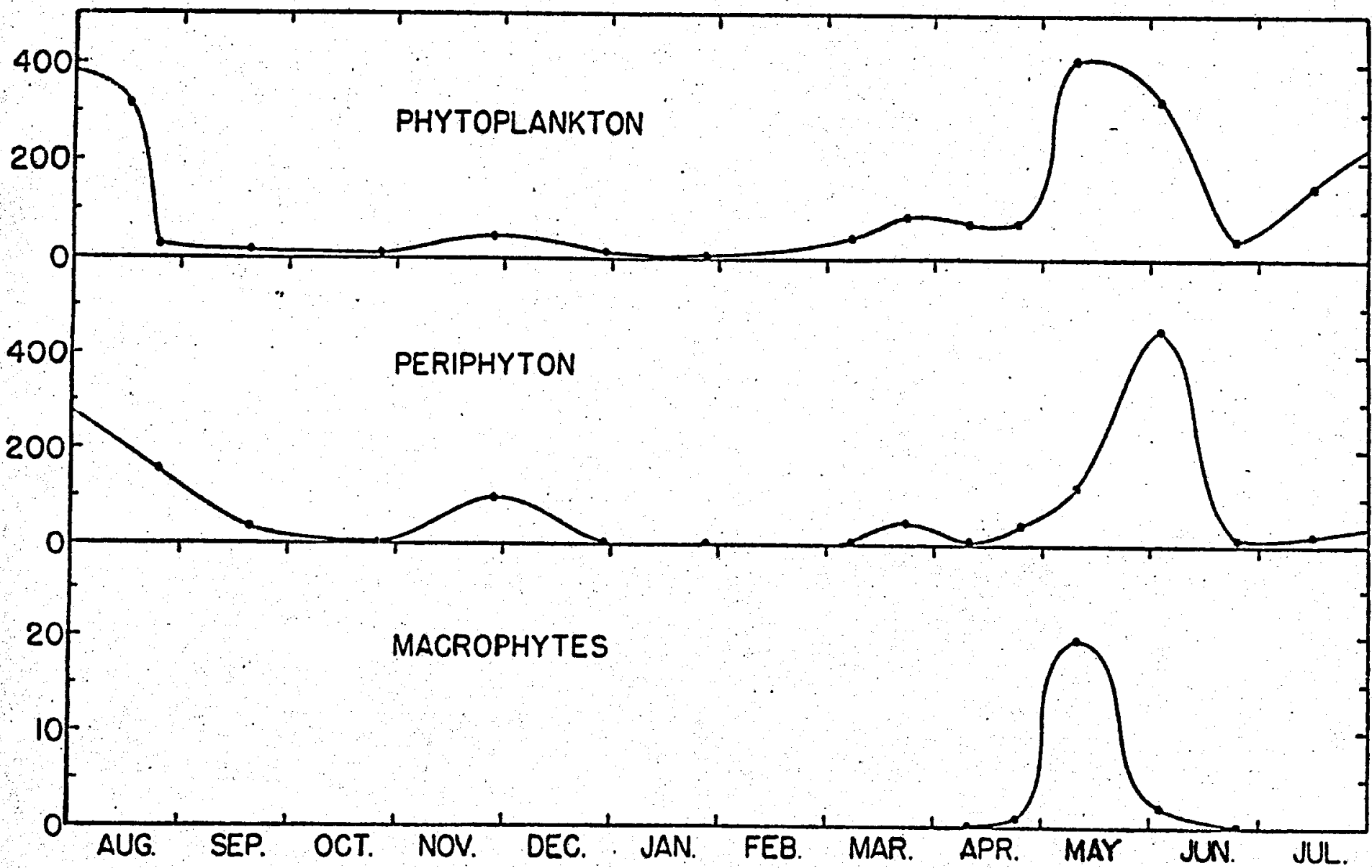

Figure 14. Pictorial comparison of the productivity and contribution of each floral component to the total. Phytoplankton averages the highest productivity with $101 \mathrm{kgC} /$ lake/day; periphyton next with $76 \mathrm{KgC} /$ lake/day; and macrophytes the least with $1.36 \mathrm{KgC} /$ lake/day. 


\section{Environmental Consultants}

\section{Water Quality Impacts from Nonelectrical Uses}

The water quality impacts arise from uncontrolled and controlled discharges of geothermal effluents and drainage from livestock holding corrals. Other effluents may arise that are associated with processing such as lumber and plywood and some types of manufacturing. ECOVIEW believes that most geothermal effluents can be reclaimed if below $100 \mathrm{ppm}$ of boron. If above that level, reinjection should be standard practice. Drainage from livestock pens is considered a valuable usable asset for nutrients for livestock, fish, shrimp, algae, poultry, etc. Their reclamation and use is part of the cascade operations identified in the suggested uses. Waste materials from manufacturing can be reclaimed or disposed of in acceptable manner once they are identified.

\section{VEGETATION}

The Borax Lake Basin and High Valley lies entirely within the foothill physiographic unit of the Interior Coast Range of California. The vegetation is composed largely of zonal and azonal types, as defined by Laughenheim (1944) and Neilson (1973); transzonal communities are not developed. Figure 15 schematically diagrams the Borax Lake Basin showing the effects of aspect and geologic and pedologic materials on zonal variation.

Zonal communities reflect the broad character of the physiographic landscape unit and represent the climax, subclimax, and successful communities that are developed primarily under the influence of the regional or local clifnate. 

zonal communities present in the area are:

Grasslands - California introduced annual grasslands; California prairie.

Savannah: valley oak

Chaparral: Chamise; chamise - buckbrush - scrub oak

Open woodlands: Blue oak; Digger pine - toyon - manzanita

Dense woodlands: Digger pine - interior live oak - buckeye manzanita; buckeye - mountain mahogany interior live oak; interior live oak

Transzonal communities result from intense modifications of zonal environmental factors, thus dramatically affecting zonal characteristics and often acting across one or more vegetational type zones. Riparian communities are good examples, but no identifiable riparian communities exist within either Borax basin or High Valley. A rudimentary community is weakly developed near the outlet of the single watercourse that enters Borax Lake. Its characteristics, however, are so closely related to fresh water marsh ecotones; that it has not been described separately.

Azonal communities usually exhibit nearly uniform characteristics, regardless of the physiographic division in which they are found. Azonal communities found in the Borax lake Basin are: alkali marsh, fresh-water, marsh, ruderal, anthropogenic (man-manipulated). The only azonal communities found in High Valiey are irrigated pastures. 


\section{EQVMEA}

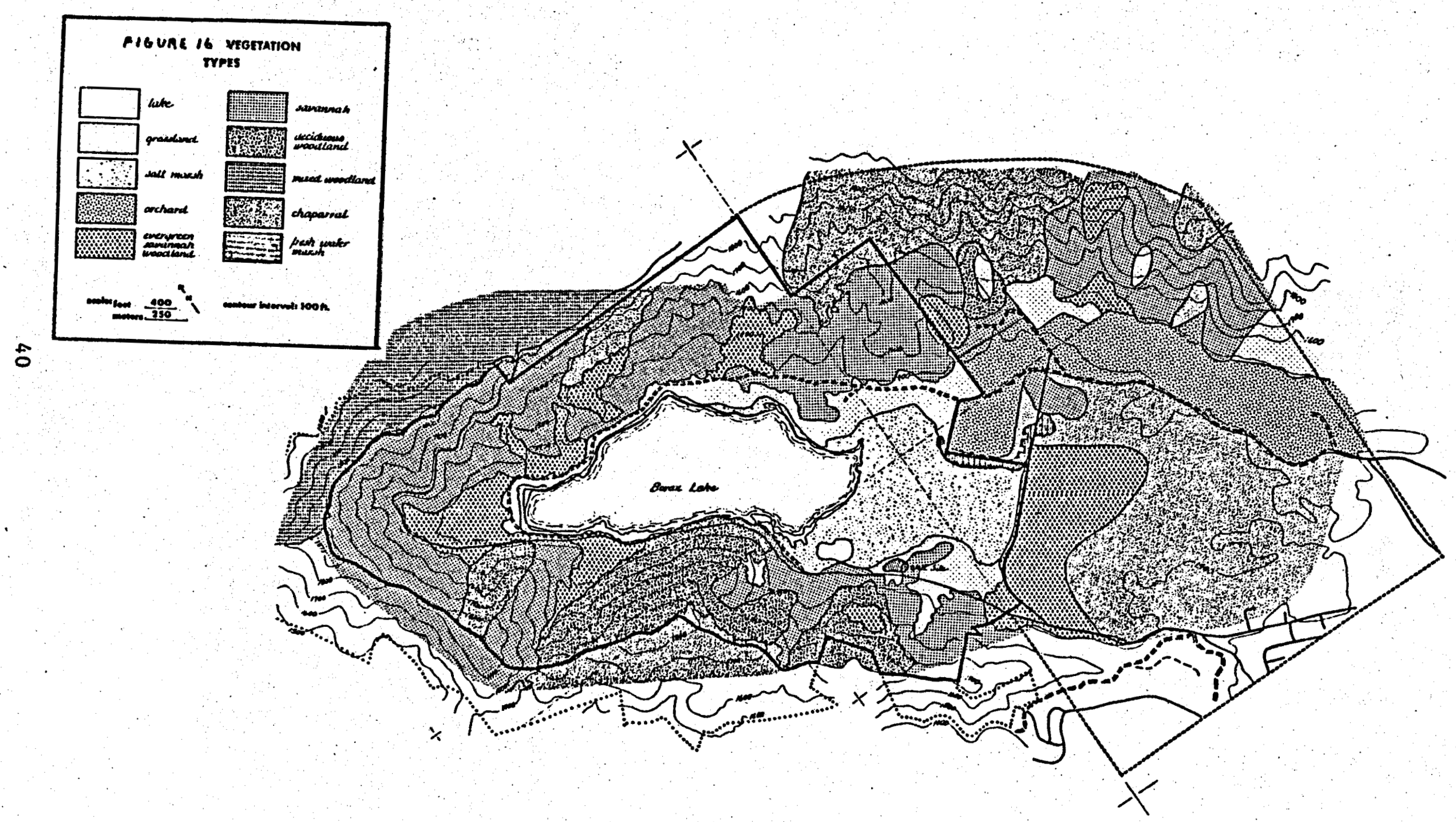


Figure 16 shows the distribution of vegetation types in the Borax Lake Basin. These are broken down into communities in Figure 17. The vegetation for High Valley has not been mapped by ECOVIEW.

Plant Communities of the Borax Lake Basin

The characteristics of each community are briefly discussed. Because vegetation analysis was done during mid-winter, an accurate inventory of each community's flora was not technically possible: most herbaceous forms are only in the seedling stage or have not started due to the long mid-winter drought. These descriptions were written specifically for the Borax Lake Basin. However, they generally apply to High Valley also.

California Introduced Annual Grassland

This community occupies nearly all well-drained open slopes and also occurs with minor variations under the blue oak woodland. Cover ranges from 60 to 1158 and average effective height is 10 to $25 \mathrm{~cm}$ depenaing upon aspect and soil quality. Composition appears highly variable from place to place. It encroaches into the California prairie, the ruderal, and the few examples of native perennial herb comunities.

Grass dominants are slender wild oats (Avena barbata), soft chess (Bromus mollis), ripgut (B. diandrus), nitgrass (Gastridium ventricosum), annual fescues (Festuca sp.) and medusa-head (Elymus caput-medusae). Broadleaf herbs are filaree (Erodium sp.), napa thistle (Centaurea melitensis), several annual clovers (Trifolium sp.), bur clover (Medicago polymorpha), Crypthantha hispidula, clarkia (Clarkia sp.), popcorn flower (Plagiobothrys nothofulvus), linanthus (Linanthus sp.), tar weed (Hemizonia sp.), and annual lotus (Lotus sp.). 


\section{California Prairie}

This community is very weakly represented on the lake's east side, on open, well-drained slopes bordering oak savannah. Effective plant height is $15 \mathrm{~cm}$ and cover is about $60 \%$. The community is marked by the presence of needle-and-threadgrass (Stipa lepida), a blue bunchgrass (Poa palustris), and buckwheat (Eriogonum latifolia); otherwise, most the dominants of the introduced annual grasses are present.

\section{Valley Oak Savannah}

A very narrow strip of valley oak savannah is located on the lake's east side on higher, well-drained flats. The cover of the valley oak (Quercus lobata) and the occasional blue (Q. douglasii) and live oak (Q.wislizenii) present, amounts to about 158. These trees are the largest in the study area. Introduced annual grassland occurs in the spaces between trees; but directly under the trees, where leaf mold has accumulated, the nitrophillous plants miner's lettuce (Montia perfoliata), ripgut, Mediterranean barley (Hordeu geniculatum) and chickweed (Stellaria media) become dominant.

Chamise

On several southwestern slopes where soils are thin, welldeveloped chamise communities exist. In most cases they are monotypic, $i$. e., consist entirely of chamise (Adenostema fasciculata); however, in several places, buckbrush (Ceanothus cuneatus) and toyon (Heteromeles arbutifolia) are present. Cover is on the order of 958, and the effective height at this time is $1.2 \mathrm{~m}$, ranging from 0.75 to $2 \mathrm{~m}$. Other species encountered were death camas (zygadenus fremontii), chaparral honeysuckle (Ionicera interrupta), and soapweed (Chlorogalum pomeridianum). 
Where an ecotone is formed between chamise and shrubby woodland on north and northeast-facing slopes, species composition consists predominantly of chamise intermixed with buckbrush, big manzanita (Arctostaphylos manzanita), and toyon in about equal proportions. Pitcher sage (Lepachinia calyciua), deer brush (Lotus scoparius), nightshade (Solamum xanti), shrubby mimulus (Mimulus aurantiacus), and yerba santa (Eriodictyon californicus) occur in small scattered stands.

Chamise-Buckbrush-Scrub Oak

Floristically more varied then the chamise community, this community consists of, in addition to the dominants, big manzanita, shrubby interior live oak (Quercus wislizenii var. frutescens), mountain mahogany (Cercocarpus betuloidés), and toyon in low numbers. The understory varies from nonexistent to a sparse cover and includes death camas, bed straws (Galium sp.), annual festucas, hedge parsley (Torilis nodosa), soft chess, and other members of the introduced annual grassland.

Total cover ranges between 60 and 1158, depending upon the understory, type soil depth, and local species composition. Being a very dense community, fireload is nearing maximum levels.

Blue Oak Woodland

This community occupies south, southeast, and southwest-facing slopes, mostly toward the upper portions of hillsides. Arboreal cover ranges from 30 to 858 and total cover approaches 958 . Where tree cover is less dense, the introduced annual grass thrives, but under heavier tree cover it becomes sparse and changes composition to favor bur-chervil (Arthriscus scandicina), linanthus, ripgut, California buttercup (Ranunculus californicus), yarrow (Archilles borealis), and other natives. Hillside needleand-threadgrass also occur. 


\section{Digger Pine-Toyon-Manzanita}

In a few areas on southwestern-facing slopes, this association is present. Trees and shrubs are scattered; cover amounts to perhaps $30 \%$ and the interspaces are occupied by introduced annual grassland. The shrubs are large and vigorous--about 2.5 to $3.7 \mathrm{~m}$ ( 8 to 12 feet) high--and branches are carried to the ground, thus forming beautiful mounding habits.

Digger Pine-Interion Live Oak-Buckeye-Manzanita

This community occupies east-facing slopes, but can be interspersed with blue oak and buckeye-mountain mahogany communities. This is a shrubby woodland. Big manzanita and interior live oak often form an understory to larger live oak and Digger pine (Pinus sabiniana). Several buckeye (Aesculus california) are large specimen plants, but for the most part they attain only 3 to $4.5 \mathrm{~m}$ ( 10 to 15 feet) in height. Redbud (Cercis occidentalis), poison oak (Rhus diversiloba), snowberry (Symphoricarpos rivularis), and honeysuckle occur. Several stands also support scrub oak (Quercus dumosa) in low numbers. The herbaceous ground layer appears to have a varied composition but its full range could not be accurately determined. The following are common and readily identified in the mid-winter season: soft chess, slender wild oats, clovers, Western and California buttercups, shooting star (Dodecatheon hendersonii), Chinese houses (Colinsia heterophylla), annual waterleaf (Nemophilla pedunculata), California fescue (Festuca californica) and a perennial brome (Bromus enerimus).

Buckeye-Mountain Mahogany (not in High Valley)

This appears to be a somewhat unique association occurring on the cooler parts of north-facing slopes. Total cover approaches 


\section{Environmental Consultants}

858. While a few interior live oak and Digger pine occur, they are not very important. The herbaceous layer is rich and varied. California fescue, wild ryegrasses (Elymus triticoides, E. glaucus). bedstraw, bur-chervil, lomatium (Lomatium sp.), Western buttercup, miner's lettuce, annual waterleaf, perennial brome, and squirreltail (Sitanion hystrix) grass are common. Poison oak is also common in places, especially around rock outcrops.

Interior Live Oak

This community occupies lower portions of draws and small canyons. Where cover approaches 80 to 958 , there are no understory or shrub components. Where cover is less, a variety of associates occur. Trees, especially along ecotones, may include valley oak, Digger pine, and blue oak. Poison oak, big manzanita, yerba santa, and snowberry occur in low numbers, especially where disturbance has occurred.

The herbaceous layer includes common (Avena fatua) and slender wild oats, reflexed fescue (Festuca reflexa), squirreltail grass, wild rye (Elymus glaucus), small hairgrass (Aira caryophyllea), California fescue, and soft chess as the grass components. Filaree, clarkia, iris (Iris macrosiphon), Napa thistle, bull thistle (Circium vulgare), bedstraw, and dove-foot (Geranium molle) are common broadleaved plants.

In the deepest part of the Borax Basin canyons an unusual variant (for the study area) occurs along the watercourse, flowering ash (Fraxinus dipetala) and an adventive elm. Among the live oak, poison oak, buckeye, snowberry, and mountain mahogany are found. The herbaceous layer includes miner's lettuce, California maidenhair fern (Adiantum jordanii). shooting star, woodland star (Lithopragma heterophylla), water- 


\section{Environmental Consultants}

leaf, bedstraws, Chinese houses, and the vine Dutchman's pipe (Aristolochia californica), among many others that could not be identified at this season.

\section{Alkali Marsh (not in High Valley)}

A striking feature of the Borax Lake Basin is the extensive alkali marsh that surrounds the lake. It forms a definite continuum of vegetation zones based on decreasing salinity as ground levels rise away from the lake edge. In shallow water, ditch grass (Ruppia maritima) is abundant. There is a wave and wash area essentially devoid of plants, then a broad zone supporting an almost pure stand of salt grass (Distichlis spicata); this zone grades into a community marked by salt rush (Juncus leseuri) . Within this zone heliotrope (Heliotropium curassavicum), wild lettuce, and sour clover (Melilotus indicus) are found. In turn, the zone gradually changes to one marked by alkali barley (Hordeum depressum), but also containing filaree, soft chess, black mustard (Brassia nigra), butter and eggs (Orthocarpus erianthus), and the bicolored lupine (Lupinus bicolor). This then grades into the introduced annual grassland or a ruderal community depending upon the position around the lake.

Such zonation is very well developed around the north, east and south portions of the lake, but is rather intermittent on the west side because of more precipitous banks. The alkali grass marsh is very extensive to the south of the lake and growth is luxuriant.

Fresh-water Marsh (not in High Valley)

Cattails (Typhus angustifolium) mark areas where fresh water is standing. Teasel (Dipsacus sylvestris), dock (Rumex sp.) 
heliotrope, horse nettle (Urtica holosericea), aster (aster sp.), thistle (Cerasium sp.) mark the extent of fresh water drainages or higher well-drained mounds within the salt marsh.

The most extensive area lies along country club Lane toward the lake's east end. Two water storage ponds have been constructed to impound fresh water, but the marsh continues to flourish.

\section{Ruderal}

These communities are weedy aggregation occupying disturbed ground surfaces. The composition varies according to the type of disturbance. Spoil banks such as at the stock pond and old mine workings near Borax Lake, commonly have Napa and bull thistle, annual fescue, buckwheat, and some annual brome, usually ripgut. Roadsides have star thistle (Centaurea solstitulis), black mustard, woolly sunflower (Eriophyllum lanatur) (chaparral and blue oak woodland only), and yerba santa." old habitations and livestock feeding grounds invariably have horehound (Marubium vulgare), and bull thistle. Old fields are dominated by Napa and star thistles with bromes, filarees, and clovers of the introduced annual grassland forming a secondary invasion in the successional pattern.

\section{Anthropogenic}

These communities are formed where cultivation is regular, such as in walnut orcharas east of Borax Lake. Here filarees, bur. clover, miner's lettuce, and redmaids (Calyptridium quadripetalum) are common.

Rare and Endangered Species

The rare and endangered plant species known to be found in the 
Borax Lake area are Eriastrum brandegee and Hesperiolimon drymarioides. ECOVIEW was unable to establish the presence of either of these plants in our winter observations, because plants do not flower until June or July and their vegetation characteristics are difficult to differentiate from other closely-related species; the exact distribution around the lake is in doubt.

\section{FAUNA}

The occurence of faunal species is closely related to vegetation patterns. The degree to which vegetation and habitat is altered affects the modification and trends which determine changes in faunal species spectrum and relative numbers. In the case of some electrical supply fields, the scattered developments appear to have little to moderate effect on existing populations of fauna. However, the intense development considered in most cascade operations require a total removal of habitat involving 5 to 50 acres. The species involved will depend on the habitat selected for development.

The following descriptions will establish faunal characteristics for the area as a whole, however, it was written particularly for the Borax Lake Basin for Phillip Oil's EIR. No specific studies have been done on High Valley by ECOVIEW. 


\section{Environmental Consultants}

\section{Fauna Habitats}

Two distinct wildife habitat types are found in the Borax Iake Basin: (1) the lake itself, with associated salt and 'fresh water marshes, and (2) the grassland, savannah, chaparral, and woodland of the surrounding slopes and ridges. In High Valley, only the last habitat type is found.

\section{Lake and Associated Habitats}

Borax Lake's major importance as wildlife habitat is in providing a resting and feeding place for waterfoul. Several hundred American coots (Fulica americana), and, perhaps, 100 ruddy ducks (oxyura jamaicensis) were noted on each of three fleld visits. Smaller numbers of other duck species were seen, including mallards (Anes platyrhynchos), green-winged teal (A. Carolinensis), and shovelers (Spatula clypesta). Waterfowl usage probably would be heavier except for unusal warm, dry. winter weather allowing large populations to remain farther north along the Pacific flyway. Breeding activity probably does not occur in any significant amount, because of the general absence of fringing marsh vegetation.

Along the shoreline, small flocks of least sandpiper (Erolia minutilla) are commonly seen in winter, while killdeer (Charadrius vociferus) are permanent residents and undoubtedly nest here in small numbers. Other birds that frequently feed on the lake's muddy margins include starlings (Sturnus vulgaris) and Brewer's blackbirds (Euphagus cyanocephalus). Black phoebes (Sayornis nigricans) feed on the abundance of flies along the shoreline; these birds are often seen perching on low mud mounds or fenceposts near the lake. During the summer, several species of swallow are expected to feed extensively 


\section{Environmental Consultants}

on the abundant insect life.

In the alkaline areas surrounding Borax Lake, low marsh vegetation provides adequate cover for a number of wildlife species. Evidence of burrowing rodents such as Botta's pocket gopher (Thomomys bottae) and California vole (Microtus californicus) is abundant. The western harvest mouse (Reithrodontomys megalotis) and house mouse (Mus musculus) are also expected to occur here. Coots, killdeer, and black phoebes are commonly seen in this habitat. Other birds that utilize the salt marsh for feeding or shelter include water pipits (Anthus spinoletta), savannah sparrows (Passerculus sandwichensis), western meadowlarks (Sturnella neglecta), and dark-eyed juncos (Junco hyemalis).

Near the southeastern end of the lake are areas of taller marsh vegetation, including clumps of cattails surrounding some natural springs. Characteristic bird species associated with this habitat are red-winged blackbirds (Agelaius phoeniceus) and long-billed marsh wren (Telmatodytes palustris).

A number of predatory birds and mammals utilize the marshlands as hunting grounds. Raptors seen actively foraging include red-tailed hawks (Buteo jamaicensis), marsh hawks (Circus cyaneus), and American kestrels (Falco sparvarius). Dogs and cats from the adjoining housing development appear to be the most important mammalian predators.

Woodland Chaparral and Grassland Habitat

The various woodland communities share much the same faunal elements and show the greatest abundance and diversity of wildlife. Amphibians and reptiles are important members of the woodland fauna. In most areas, the rough-skinned newt (Taricha granulosa), 


\section{Environmental Consultants}

ensatina (Ensatina eschscholtzi), arboreal salamander (Aneides lugubris), and Pacific treefrog (Hyla regilla) are expected to be the most commonly encountered amphibians during winter and spring. Iizards are represented by western fence lizard (Sceloporus occidentalis), western skink (Eumeces skiltonianus), and southern alligator lizard (Gerrhonotus multicariantus). While snakes are not expected to be common, the gopher snake (Pituophis melanoleucus), common kingsnake (Iampropeltis getulus), and western rattlesmake (Crotalus viridis) should be present in small numbers.

Woodland habitats are of particular importance because they support a great variety of bird species; the most comon being listed in Table 13 according to their seasonal occurrence. Several species of woodpeckers are abundant; their abandoned excavations in oaks and Digger pines provide nesting holes for many other birds, such as ash-throated flycatchers (Myiarchus cinerascens) and plain titmice (Parus inornatus). The only game species to occur with regularity are California quail (Lophortyx californica) and mourning doves (zenaida macroura). Small songbirds in large numbers overwinter within the woodland communities.. In the spring, many move north or to higher elevations; but they are replaced by summer resident species that breed here. The most important raptors are the Cooper's hawk (Accipiter cooperii), red-tailed hawk, screech owl (Otus asio), and great-horned owl (Bubo virginianus). 
Environmental Consultants

Table 13. Characteristic Birds of the Woodland Communities within the Borax Iake Study Area.

\begin{tabular}{|c|c|c|}
\hline Permanent Residents & Winter visitors & Summer visitors \\
\hline $\begin{array}{l}\text { California quail } \\
\text { Mourning dove } \\
\text { Common flicker } \\
\text { Acorn woodpecker } \\
\text { Nuttall's woodpecker } \\
\text { Scrub jay } \\
\text { Plain titmouse } \\
\text { Bushtit } \\
\text { White-breasted nuthatch } \\
\text { Bewick's wren } \\
\text { American robin } \\
\text { House finch } \\
\text { Lesser goldfinch } \\
\text { Rufous-sided towhee } \\
\text { Brown towhee }\end{array}$ & $\begin{array}{l}\text { Varied thrush } \\
\text { Ruby-crowned kinglet } \\
\text { Yellow-rumped warbler } \\
\text { Dark-eyed junco } \\
\text { Golden-crowned sparrow }\end{array}$ & $\begin{array}{l}\text { Ash-throated flycatcher } \\
\text { Western wood peewee } \\
\text { Blue-gray gnatcatcher } \\
\text { Orange-crowned warbler } \\
\text { Black-headed grosbeak } \\
\end{array}$ \\
\hline
\end{tabular}

Mammals characteristic of woodland communities include a number of small rodents: Sonoma chipmunk (Eutamias sonomae), western gray squirrel (Sciurus griseus), Botta's pocket gopher, deer mouse (Peromyscus maniculatus), and dusky-footed wood rat (Neotoma fuscipes). In addition, shrews (Sorex ornatus) and moles (Scapanus latimanus) are expected in wooded areas. Major predators are raccoons (Procyon lotor), striped skunks (Mephitis mephitis), and bobcats (Lynx rufus), with mountain lions (Felis concolor) likely to visit rarely. Some evidence of feral pigs (Sus scrofa) was seen; black-tailed deer (odocoileus hemionus columbianus) are present, but in rather low numbers. 


\section{Environmental Consultants}

Grassland and savannah communities are widespread, but relatively less important and productive than woodland as wildlife habitat. Many animal species from the woodlands range through the savannahs and into the grassland as well. However, some faunal elements find their major center of distribution in the grasslands. The western toad (Bufo boreas) and ringneck 'snake (Diadophis punctatus) fall into this category.

Mammals found mainly in the grassland/savannah habitat are burrowing forms such as the california ground squirrel (Spermophilus beecheyi) and California vole.

The most distinctive and extensive chaparral communities are stands of 2 to $3 \mathrm{~m}$ ( 6 to 8 feet) high chamise. Because of the hot, ary conditions and general lack of springs and seeps, amphibians do not utilize this community to any extent. Pacific tree frogs are expected in small numbers in rock outcrops and in the moister ravines. No reptiles were seen during the January field surveys, but western fence lizards are undoubtedly the most common species, and shoud be quite active by March or April. Snakes are expected in small numbers and would include the striped racer (Masticophis lateralis),

\section{Table V-14. Characteristic Birds of the Grassland/ Savannah Communities within the Borax Iake Study Area}
American kestrel
Barn owl
Western kingbird
Horned lark
Western bluebird
Common crow
Loggerhead shirke
starling
Western meadowlark
Northern oriole
Brewer's blackbird
Lark sparrow 
gopher snake, and western rattlesnake.

Several typical chaparral bird species normally observed to be present: rufous-sided and brown towhees (Pipilo erythrophthalmus

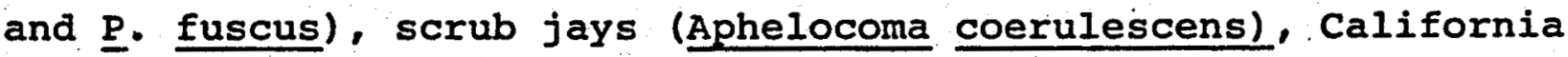
thrasher (Toxostoma redividum), and Anna's humingbird (Calypte anna). White-crowned sparrows (zonotrichia leucophrys) are winter visitors, characteristically feeding along the edges of grassy patches within the chamise. Turkey vultures (Cathartes aura) and red-tailed hawks commonly forage over chaparral. Coveys of California quail appear to be most common along the edges where this community meets woodland with grassy understory.

Deer populations appear to be relatively low, probably because of the poor quality forage. Both deer and black-tailed jackrabbits (Lepus californicus) favor chaparral edge situations. Several species of small rodents occur, especially around rock outcrops where more cover is available. Dusky-footed woodrats, and two or more species of mice (Peromyscus) are probably the most abundant in this group. In grassy openings, Botta's pocket gopher and California vole occur commonly. Predators feeding on these rodents would include coyotes (Canis latrans), gray foxes (Urocyon cinereoargenteus), spotted skunks (Spilogale gracilis), ring-tails (Bassariscus astutus), and bobcats.

Rare and Endangered Species

At present, evidence of any rare or endangered animal species occurring within the study area is lacking. Field investigations have not identified any unique or unusual valued habitat features for wildife species. Although Borax Lake itself is used to a certain extent as a resting and feeding place by migratory and resident waterfowl, it is not of great importance in this respect. 


\section{APPENDIX I \\ DETERMINATION OF WIND DATA}

To determine an approximation of wind speeds, variability, and periodicity, data from the Uklah airport had to be used. The distance and topography between Ukiah and Borax Lake directly affects the resulting interpretations.

The Ukiah airport is Iocated on the west side of a 4.8 to $8 \mathrm{~km}$ ( 3 to $5 \mathrm{mi}$ ) wide, gradually curving valley oriented nearly NS north of the station and NNW-SSE south of the station. The east side of the valley is bounded by a continuous string of ridges stretching approximately $12.8 \mathrm{~km}(8 \mathrm{ml})$ north and south of the station. Local canyons oriented NNW-SSE enter the west side of the valley north and south of the station. Therefore, terrain features favor wind directions of $\mathrm{N}, \mathrm{NNW}$ and SSE -- as are observed. A large elongated hill SW of the station is expected to shadow the station from SW winds. Easterly winds are an infrequent occurrence throughout most of north western California, and therefore the frequency of both south-westerly and easterly wind is expected to be low.

These topographic features, coupled with the fact that the area around the airport appears to be a zone of frequent convergence between distinct patterns of marine air intrusion (1.e., the north-westerly flow inland from the coast near Fort Bragg, the southerly flow from the Point Arena area, and the extended sea breeze flow up the Russian, Sonoma, and Napa valleys) suggest a high frequency of calm conditions at the station. These conditions are in fact observed with an annual calm average of $57.6 \%$.

In contrast, the Lower Lake area is in a broad basin elongated in a general NW-SE direction, but with less restricted topographic channeling of wind flow.

The wind climatology for Ukiah is shown in thirteen figures (Figure AI-1 through AI-13). These lllustrate the average wind speed from each of the sixteen compass points and the percent occurrence frequency of each direction for an annual and a monthly mean of hourly observations for the years 1955 through 1964. Data is derived from summaries colpiled by National Climatic Center (N.O.A.A.). Also shown are the percentages of calm for each averaging period. Average wind speed (knots) and percent frequencies by direction exclude calm periods (1.e., represent distribution only for when the wind is non-zexo).

Results show that for Ukiah, the mean wind speeds generally increase from a minimum of two to four knots in January to a maximum of five to elght knots in August. The highest average wind speeds in each period generally coincide with the most frequent directions (1.e., $\mathrm{NW}, \mathrm{N}$ and SSE). Conversely, the highest frequency of calm occurs in.winter ( $76 \%$ ) in December) and Ieast often in summer (43\% in June). 


\section{Convironmental Consultants}

Speed

$\%$ Frequency

Figure Ap-7 to 12. The figure on the left is speed, the outer circile is $10 \mathrm{mph}$, the inner is $5 \mathrm{mph}$. The figure on the left right is \% frequen cy, the outer circle is 20mph, the Inner $10 \mathrm{mph}$.
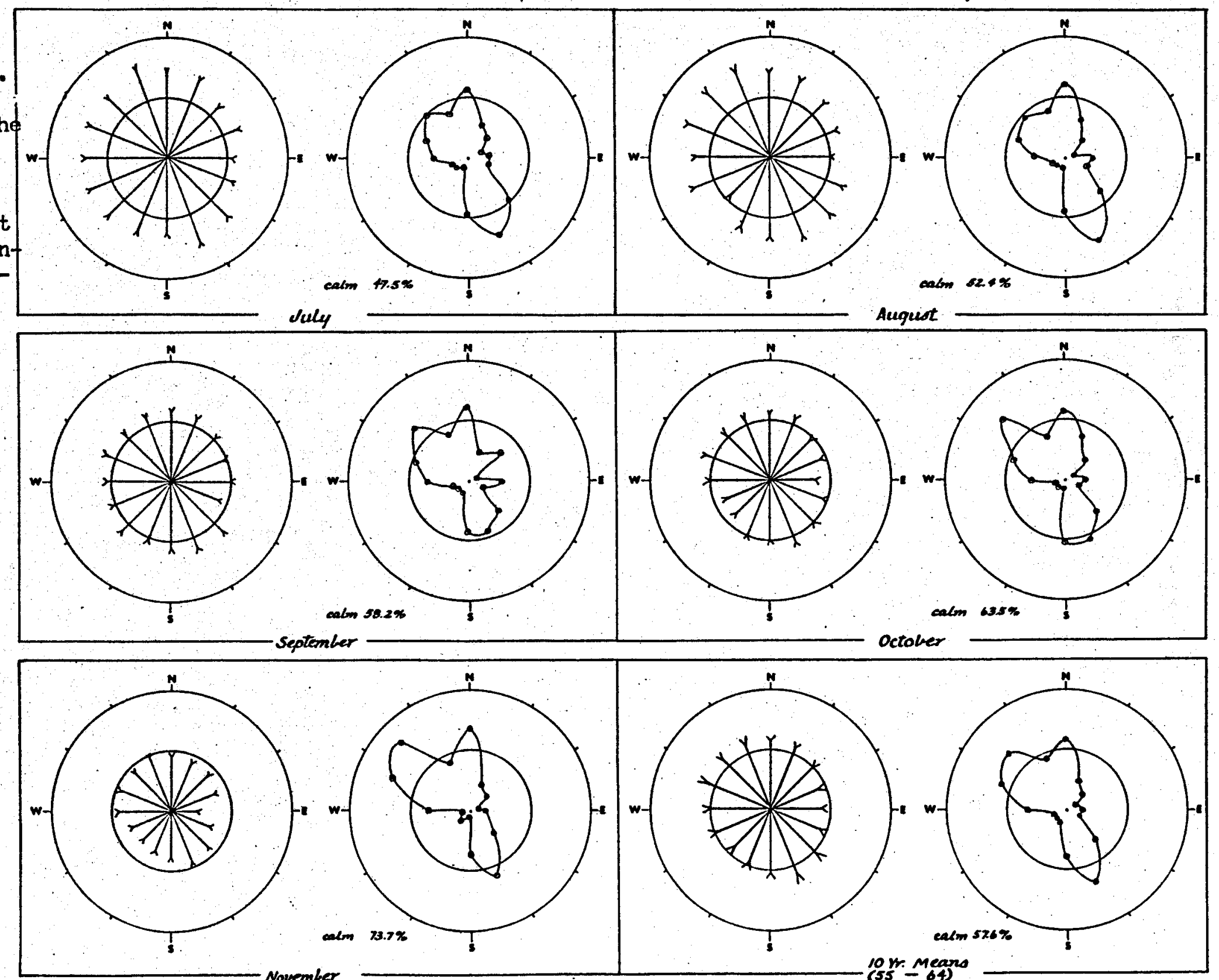


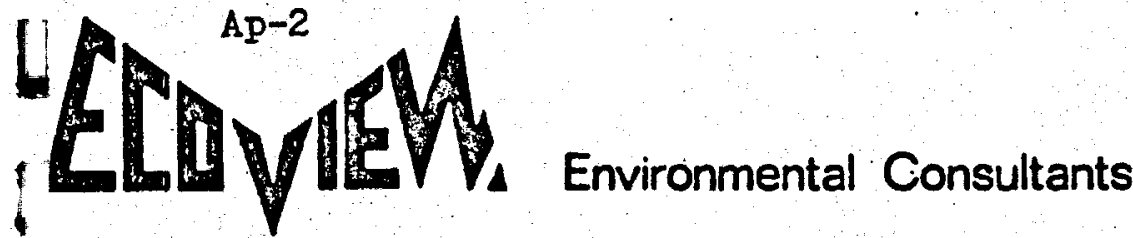

The frequency distribution is essentially tri-modal, with about equal probabilities of $\mathrm{NW}, \mathrm{N}$, or SSE winds in the annual mean. This distribution changes seasonally, with higher frequencies of the southerlies during the stormy season (December through February), north-westerlies in spring and fall, and more frequently southerlies again in the summer.

- For the Clear lake area, the same general characterlstics are expected. However, the actual number of occurrences for each direction will be higher since the expected number of calms will be significantly lower. Furthermore, the data suggests that the frequency of wind directions at Clear Lake, during calm at Ukiah, is distributed in about the same way as the distribution shown in the wind roses.

To estimate air stability classes (Pasquills classification), Turner's method was used on N.O.A.A. data. This method essentially estimates, from solar altitude, type and amount of cloud, and measured surface wind speed, net radiation to the surface to define the near ground air stability. While this scheme is subject to criticism for a number of reasons, the method does allow reasonable average estimates to be made from routine observations. Furthermore, since the cloud and solar altitude data is valid for large areas and since, for wind speeds less than six knots, the radiation estimate is the primary. determinant of the class, the approximate classification is valid over a fairly large area. 
Environmental Consultants

ENVIRONMENTAL REPORT

Study Area II

Mt. Konocti - Thurston Lake

Prepared under sub-contract to Geonomics, Inc. as part of Phase Zero of the ERDA grant "Alternative Agribusiness and Industrial Uses for Exhaust Heat from Geothermal Waste Fluid, Lake County, California".

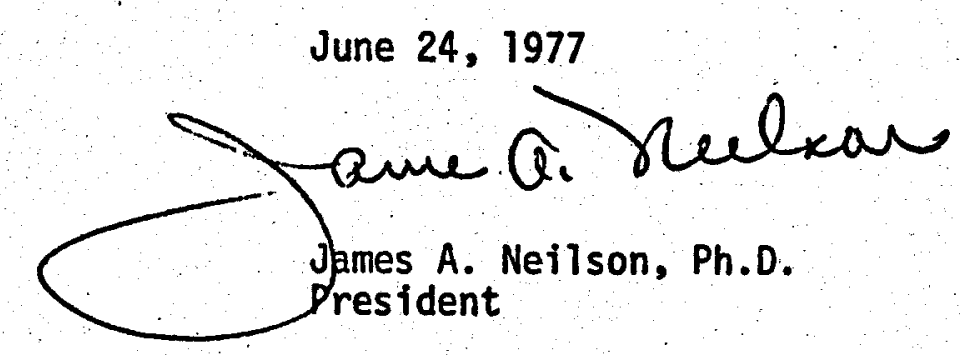


Environmental Consultants

\section{TABLE OF CONTENTS}

I. STUDY OF AREA II - GENERAL ASPECTS 1 Area Characteristics .............. Resource Status ................. 3

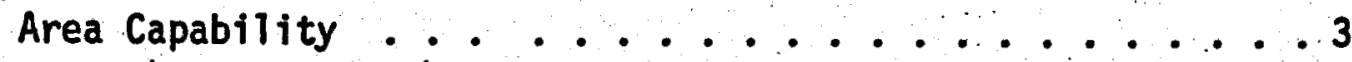
Environmental Constraints ............. 6

II. THE AIR RESOURCE, STATUS AND QUALITY 7

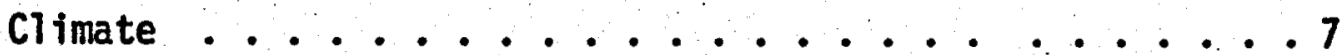
Air Quality .........................

The Effects of Non-Electrical Uses ............ 10

III. THE WATER RESOURCE, STATUS ANB QUALITY. $\ldots 10$ : Hydrology and Water Quality .............. The Effects of Non-Electrical Uses ............ 16

IV. THE VEGETATION RESOURCE 16

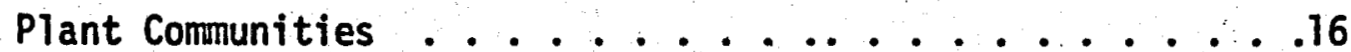
Rare and Endangered Plants .................... The Effects of Non-Electrical Uses ........... . . . .

V. THE FAUNAL RESOURCE 19 Aquatic Biology . . . . . . . . . . . . . 22

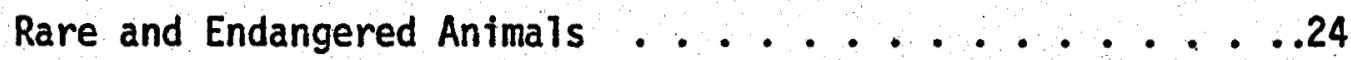




\section{$b$

TABLE 1. KETTENHOFFER \#1 WELL ................ 4-5

. TABLE 2. MONTHLY AVERAGE PRECIPITATION ....... 8

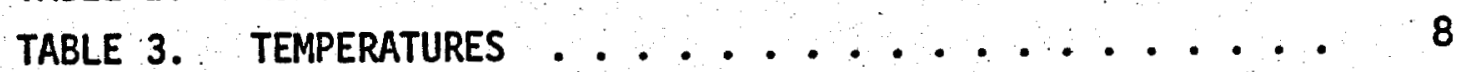

TABLE 4. HEATING DEGREE DAYS .......... 8

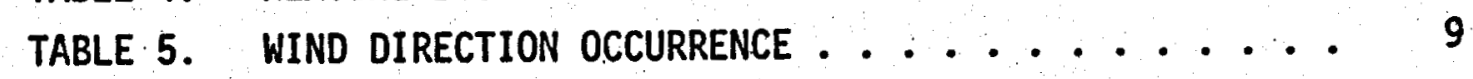

TABLE 6. KELSEYVILLE VALLEY GROUND WATER ANALYSIS . . . 11

TABLE 7. MEAN FLOWS IN KELSEY CREEK ............... 13

TABLE 8. WATER QUALITY OF HIGHLAND CREEK $\ldots \ldots \ldots$

TABLE 9. MEAN FLOWS IN ADOBE CREEK $\ldots \ldots \ldots 14$

TABLE 10. WATER ANALYSIS FOR THURSTON LAKE $\ldots \ldots \ldots$ 


\section{Area Characteristics}

The Thurston Lake - Mt. Konocti study area comprises a five to six mile strip from Lower Lake to Kelseyville ( \pm 45 square miles) along the south shore of Clear Lake. If much of the Big Valley agricultural area west of Kelseyville is included an additional 30.5 square miles should be added. Its maximum width and length are about 7 miles each. Thurston Lake itself covers approximately $2 / 3$ of a square mile with no direct surface outlet to Clear Lake. Mt. Konocti is a large volcanic cone that covers \pm 6 square miles. It rises to $4200^{\prime}$ and is $2875^{\prime}$ abave lake level. Rellef in this portion of the study area varies between $1325^{\prime}$ (lake level) and $2400^{\circ}$, characterized as mountainous with round topped ridges, small volcanic cinder cones (e.g., Sugar Loaf and Round Top Mt.), and some flats (e.g., Hesse, Manning and Elly) between ridges that tend to flood in sustained wet weather. Soils' parent material are principally volcanic cinders or ash with considerable intermixed obsidian.

Big Valley is largely (but not exclusively) allivium, relatively flat or gently rolling hills, with rich solls. This is the largest single block of agricultural soils in the county. Pears, walnuts, some grapes, and irrigated pastures are the principal crops.

The area between Mt. Konocti and Thurston Lake supports some walnut orchards; but mostly land use is devoted to open space, cattle ranching, and retirement living. Most of the area has a very low population density; however, several large lakeside resorts have been built, especially near Mt. Konocti. 


\section{Environmental Consultants}

The area at the south end of Clear Lake called Anderson Flat is being considered as a wildiffe preserve - much of it is a marsh and sometimes flooded when lake levels are high.

\section{Resource Status}

Several geothermal wells have been dug (to 8,000') near Mt. Konocti. All have been plugged and abandoned so far. Other shallow wells drilled for water have either warm or cold water, considerable methane, and some hydrogen sulfide. Temperature probes done by the U.S.G.S. and Division of Mines \& Geology show that the area under the south-east end of Clear Lake and Thurston Lake are very favorable for hot water. To date, most of the leasehold land has been acquired by development companies. Several small blocks are still held by public agencies and private owners who do not wish to lease to development companies. Methane gas wells and natural seeps are known to several places in Big Valley and a gas well has been dug in the southwest portion.

The extent towhich geotheraml energy could be extracted in Big. Valley is not currently known. The rest of the area will undoubtedly be able to support non-electrical operations once wells are developed. The Kettenhoffen well in Ely Flat drilled by Magma Power in 1976 yielded temperatures up to $270^{\circ}$ F. at $5,800^{\prime}$ and was largely hot water, Table 1. Union 0 il Company has proposed drilling three wells near Thurston Lake, but has been delayed by litigation.

\section{Area Capability}

Land forms in the Thurston Lake - Mt. Konocti portion severely restrict the area for non-electrical uses. Steep terrain is the principal factor; however, the flats, that would otherwise be attractive, are subject to flooding at certain periods of the year. Unless extensive 
Environmental Consultants

\section{TABLE 1}

The Kettenhoffen \#1 Well information submitted January 24, 1977.

1. History, E-log, and temp. log available for public release from Div. of Oil and Gas. Apparently no lithology log is avallable from D. 0 . G.

2. E- $\log$ shows water in formation to $5870 \pm$ depth which is depth of casing

3. Max. temp. $-310^{\circ}$ F. Max. depth: $8566^{\prime}$

4. Temp. log shows:

$$
\begin{aligned}
& 1400^{\prime}-80^{\circ} \mathrm{F} \\
& 2100^{\circ}-140^{\circ} \mathrm{F} \\
& 2600^{\circ}-160^{\circ} \mathrm{F} \\
& 3100^{\prime}-180^{\circ} \mathrm{F} \\
& 3580^{\circ}-200^{\circ} \mathrm{F} \\
& 4400^{\prime}-220^{\circ} \mathrm{F} \\
& 5000^{\circ}-240^{\circ} \mathrm{F} \\
& 5600^{\prime}-260^{\circ} \mathrm{F} \\
& 5800^{\prime}-270^{\circ} \mathrm{F}
\end{aligned}
$$

5. Summary: A hot, wet hole which was abandoned due to drilling problems. At least some serpentine was encountered.

Geology of the Barceloux and Cobb Mountain leases by Eugene Cicanelli, May, 1974, reports the following litholgy for Kettenhoffen \#1: : 



\section{Environmental Consultants}

drainage systems would be built, their use is rather limited. Limited knowledge of resource capability in Big Valley makes assessment difficult where direct applications, such as pear orchard heating or pear drying, may be appropriate. Any wells, especially hot water wells, would be very useful especially in the alluvial areas near the lake where pears need frost protection.

\section{Environmental Constraints}

The most serious potential problem in the Thurston-Konocti vicinity centers concern land disturbance giving rise to water quality degradation. Even so, this problem can be effectively dealt with by careful engineering and site selection. Since this is most likely a hot water field, proper disposal or reclaimation of spent geothermal liquids is of prime importance to both water quality and land subsidence. At the present time no non-electrical use should be considered unless the following are functional:

-- Reinjection is proven unnecessary to prevent subsidence or for disposal of contaminants.

- Waters should not be released to streams or the lake unless contaminates are reduced to acceptable discharge levels.

-- Reclaimed waters can be recycled to conventional agricultural, potable water resource or ground water recharge.

Visual aesthetics could become a problem since the route along Highway 29 between Lower Lake and Kelseyville is a scenic: corridor. Installations will have to be hidden or their aspect made permanently acceptable. Extensive installations on slopes exposed to views from the lake or resort areas will have to be treated to reduce contrast or sited to reduce impact. 


\section{Environmental Consultants}

Land use conflicts may result from large scale installations near the lake shore or in view from or in proximity to the Konocti resort area and the homes opposite Thurston Lake.

Until a clear disposition is made of the marsh area at the south end of Clear Lake (Anderson marsh and flat) no installation should be seriously contemplated that affect the area.

\section{THE AIR RESOURCE, STATUS \& QUALITY}

Climate

Climate in Big Valley is classified as temperate, semi-arid; it is characterized by dry, rainless summers with high daytime temperatures and warm.nights and by wet winters with. moderate temperatures and cold nights. Average annual precipitation ranges from about 24 inches at Kelseyvilie to about 60 inches on the slopes of Cobb Mountain at. the upper end of the basin. More than half of the annual precipitation occurs from December through February (Table 2). Average monthly temperature varies from the low 40's $F$ in January to the low 70's F in July. Extremes of $14^{\circ} \mathrm{F}$ in winter and $110^{\circ} \mathrm{F}$ in surmer have been recorded (Table 3). Frosts may occur from November through April. The number of heating degree days is presented in Table 4. Limited wind data are available for the Kelseyville area. The prevailing wind directions throughout the year are from the northwest and west. (See Table 5). Spring and summer winds average 6-8 mph, while winter average values of $2-6 \mathrm{mph}$ are reported.

Air Quality

The California Air Resources Board conducted a short-duration (Apri1 15, 1975-May 12, 1975) monitoring of ambient air at Kelseyville. The contaminants monitored included ozone, carbon monoxide, nitric oxide, nitrogen dioxide, total hydrocarbons, methane, non-methane 


\section{ELIVIEW. Emromental consuluants}

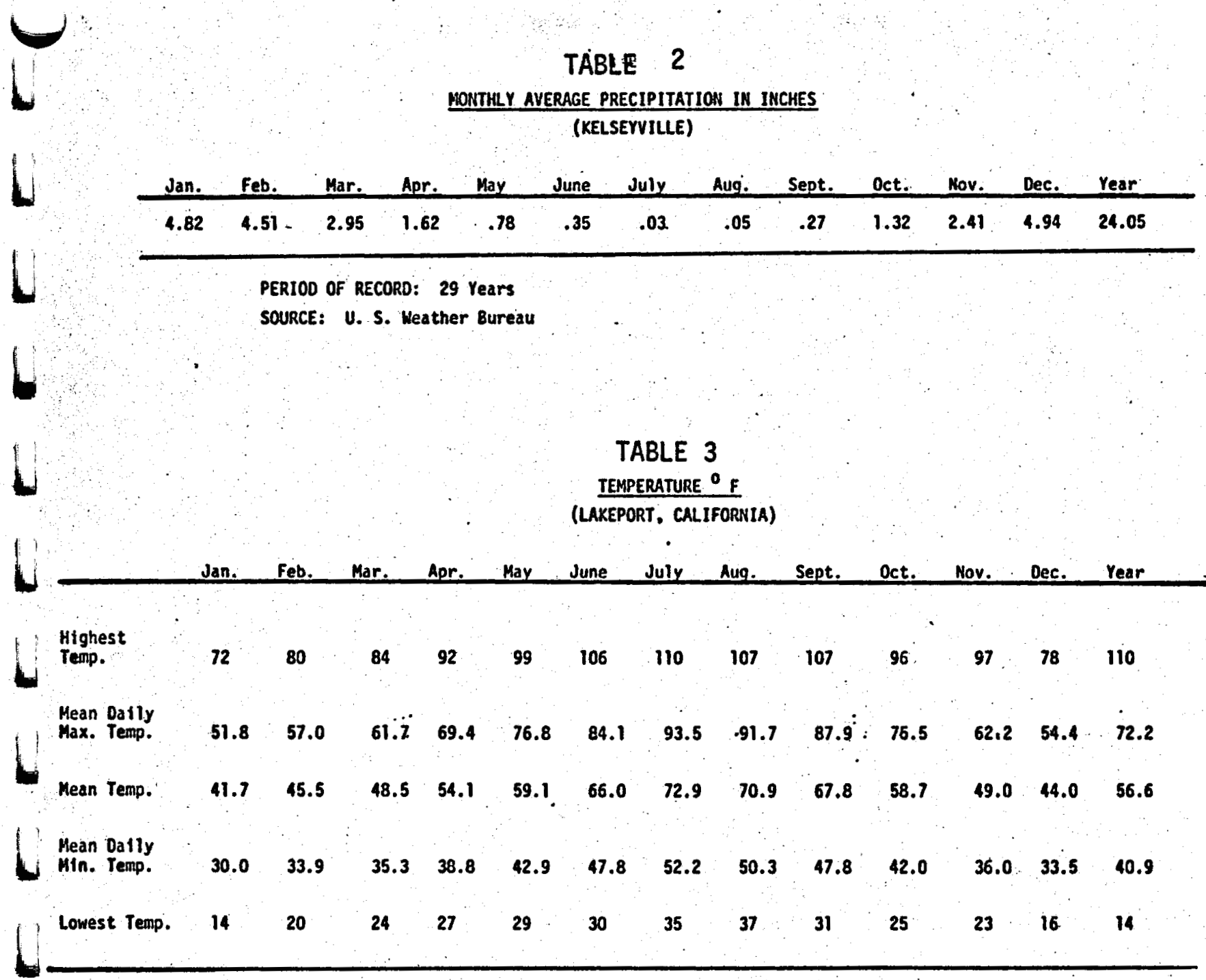

PERIOO OF RECORD: 19 Years

SOURCE: U. S. Weather Bureau

TABLE 4

HEATING DEGREE DAYS, BASE $65^{\circ} \mathrm{F}$

(LAKEPORT - KELSEYVILLE)

\begin{tabular}{rllllllllll} 
Jan. Feb. & Mar. & Apr. May & June & July & Aug. & Sept. & Oct. Nov. Dec. & Year \\
\hline 722.3 & 546 & 511.5 & 327 & 182.9 & 0 & 0 & 0 & 0 & 195.3 & 480 \\
\hline
\end{tabular}

Heating degree days equals the number of degrees below $65^{\circ} \mathrm{F}$ the dally average temperature reaches during a given season. Computed according to the foraula: ( $65^{\circ} f$ - monthiy mean temp) $X$ (number of days in month).

The degree day provides a measure of the heat demand for specific pertods in the Relseyvilie Lakeport area. 


\section{PLD VIEM. Enviromental Consultants}

TABLE 5

WIND DIRECTION OCCURRENCE, CLEAR LAKE AREA

(Prevailing Direction Expressed in Percent)

\begin{tabular}{|c|c|c|c|c|c|c|c|c|}
\hline Month & $\mathrm{N}$ & NE & $E$ & SE & s & SW & w & $N W$ \\
\hline August. (73) & & & & & & & 21 & 68 \\
\hline September & & & $x$ & & $x$ & $x$ & 29 & 41 \\
\hline October & & & $x$ & $x$ & $x$ & $x$ & 30 & 24 \\
\hline November & & & 27 & $x$ & & & $x$ & 37 \\
\hline December & & & 19 & $x$ & & $x$ & $x$ & 57 \\
\hline January (74) & & & 22 & $x$ & & $x$ & 21 & 28 \\
\hline February & & & 14 & $x$ & $x$ & $x$ & 22 & 44 \\
\hline March & & & 11 & $x$ & & $x$ & 28 & 40 \\
\hline April & & & 10 & $x$ & & & 18 & 51 \\
\hline May & & & & & & & 22 & $72:$ \\
\hline June & $x$ & & $x$ & & & & 26 & .58 \\
\hline JuTy & & & & & & & 33 & 60 \\
\hline August & $x$ & & $x$ & & & $x$ & 35 & 51 \\
\hline September & & & 13 & $x$ & $x$ & $x$ & 37. & 30 \\
\hline October & & & 13 & $x$ & $x$ & $x$ & 30 & 31. \\
\hline November & & & 17 & $x$ & $x$ & $x$ & 28 & 33 \\
\hline
\end{tabular}

(1) " $\mathrm{X}$ " indicates minor measurable wind flows.

Source: Jones and Stokes; EIR for Watson \#1 and \#2 Well Sites, 1975 


\section{Environmental Consultants}

hydrocarbons, and coefficient of haze. California ambient air quality standards for all contaminants monitored were not exceeded during the monitoring period.

\section{The Effects of Non-Electrical Use on Air Quality}

Since hot water is the most likely resource, the usual safeguards of off gas ejection of non-condensibles must be incorporated into design criteria. $\mathrm{H}_{2} \mathrm{~S}$ gas is the most likely problem, scrubbing and/or reinjection is the best solution if conflicts with affected homeowners are to be avoided.

Odors from processing a livestock operation could be potential problems, but are best dealt with on a case-to-case basis.

III. THE WATER RESOURCE, STATUS AND QUALITY.

Hydrology and Water Quality

BIG VALLEY

Ground water in Big Valley is intensely developed for irrigation, municipal, domestic, and industrial use. Wells are located throughout the area, though the greatest concentration of wells is in the lowland areas above the principal aquifers. The ground water reservoir has considerable total storage capacity within the 1 imits of 10 to 100 feet. The California Department of Water Resources (1975) reports average well yields of 450 gallons per minute (gpm) with a maximum yield of $1350 \mathrm{gpm}$. The total ground water storage capacity is estimated at 115,000 acre-feet with a usable capacity of 60,000 acre-feet. It is estimated that about 14,000 acre-feet of water can be depleted from storage without seriously affecting pumping conditions. Present annual use is estimated at 14,400 acre-feet (Lake County Flood Control and Water Conservation District, 1973). 
Water in the ground water systems of Big Valley is principally supplied by run-off from the watersheds of Kelseyville, Adobe, Highland and Manning Creeks. Ground water is generally of good quality for irrigation, food processing, and domestic uses (Table 6): Water also enters the ground water system by sub-surface flow from surrounding highlands and from buried springs. Much of this water is good quality but some, notably that originating as underflow from Mt. Konocti and as uprising spring water, has a relatively high mineral content.

TABLE 6

KELSEYVILLE YALLEY GROUND WATER AMALYSIS : 6-10-71

\begin{tabular}{|c|c|c|c|c|c|c|c|c|c|c|c|c|c|c|c|}
\hline 1 & Temp. & 으 & $\underline{E C}$ & Ca & $\underline{\mathrm{Mg}}$ & Na & $\underline{\mathbf{k}}$ & $\mathrm{CO}_{3}$ & $\mathrm{HCO}_{3}$ & $\mathrm{SO}_{4}$ & c1 & $\mathrm{NO}_{3}$ & $\underline{B}$ & $\underline{s}_{1} \underline{O}_{2}$ & TOS \\
\hline $\begin{array}{l}13 \mathrm{~N} / 09 \mathrm{H}- \\
03 \mathrm{Cot} N\end{array}$ & 59 & . 8.1 & 535 & 29 & 51 & 7.8 & 1.4 & 0 & 288 & 32 & 9.0 & 19 & 0.1 & - & $330^{\circ}$ \\
\hline $\begin{array}{l}13 N / 09 \mathrm{H}- \\
05003 \mathrm{H}\end{array}$ & 66 & 7.6 & 552 & 21 & 54 & 16 & 1.4 & & 367 & 1.2 & 7.2 & 0 & 0.5 & - & 322 \\
\hline $\begin{array}{l}\text { 13N/09W- } \\
17 \mathrm{AOI} \mathrm{N}\end{array}$ & 67 & 7.6 & 985 & 38 & 111 & 25. & 2.0 & 0 & 704 & 0.2 & 11 & 12 & 0.9 & - & 560 \\
\hline $\begin{array}{l}13 \mathrm{~N} / 09 \mathrm{~W}- \\
18 \mathrm{J01} \mathrm{M}\end{array}$ & 66 & 7.7 & 360 & 28 & 18 & 23 & 0.9 & 0 & 201 & 0.3 & 15 & 4.1 & 0.5 & & 238 \\
\hline $\begin{array}{l}13 \mathrm{~N} / 09 \mathrm{~W}- \\
22 \mathrm{J01}\end{array}$ & 60 & 8.3 & 420 & 14 & 52 & 9.8 & 1.7 & 0 & 283 & 15 & 12 & 5.5 & 0 & & 288 \\
\hline $\begin{array}{l}14 N / 09 \mathrm{~W}- \\
32 \mathrm{J01} \mathrm{N}\end{array}$ & 61 & 7.7 & 822 & 65 & 71 & 17 & 0.9 & 0 & 510 & 38 & 25 & 2.5 & 0.2 & & 477 \\
\hline $\begin{array}{l}13 \mathrm{~N} / 09 \mathrm{~W}- \\
02 \mathrm{KO} \mathrm{H}\end{array}$ & 60 & 6.9 & 980 & 19 & 100 & 20 & 1.6 & 13 & 396 & 82 & 50 & 22 & .20 & & 537 \\
\hline $\begin{array}{l}13 N / 09 H- \\
08 N 02 \mathrm{H}\end{array}$ & 68 & 6.3 & 520 & 44 & 31 & 25 & .3 & 0 & 256 & 20 & 37 & 7.0 & .1 & & 300 \\
\hline $\begin{array}{l}13 \mathrm{~N} / 09 \mathrm{~W}- \\
21 \mathrm{F02} \mathrm{M}\end{array}$ & 76 & 6.3 & 695 & 19 & 82 & 17 & $1: 9$ & 27 & 435 & 2.1 & 14. & 2.2 & 0 & & 422 \\
\hline $\begin{array}{l}\text { I3N/O9W- } \\
\text { I7AOI N }\end{array}$ & 69 & 6.3 & 1100 & 19 & 122 & 29 & 3.1 & 29 & 655 & .6 & 15 & 12.0 & 1.20 & & 612 \\
\hline
\end{tabular}

SOURCE: California Department of Water Resources Units are $\mathrm{mg} / \mathrm{l}$. 


\section{Environmental Consultants}

The principal mineral constituents of the ground water are magnesium, calcium and bicarbonate. Sodium is always present but in amounts subordinate to calcium. Chloride and sulfate are present in amounts subordinate to bicarbonate. The distinctive characteristic is the magnesium to calcium ratio which ranges from 1.5:1 to $3: 1$. Amounts of total dissolved solids (TDS) range from 350 - 1200 parts per million (ppm) averaging $400-500 \mathrm{ppm}$. Boron in some water wells is in concentrations high enough to be potentially injurious to crops: Most wells yield water containing less than $0.3 \mathrm{ppm} B$, but some wells produce $0.6 \mathrm{ppm}$ and more. Boron damage is reported for only a few areas. Known high boron wells occur in the area adjacent to Mt. Konocti and along the Big Valley Fault.

Five Creeks - Cole, Kelsey, Adobe, Highland, and Manning - enter Big Valley. Flows from these creeks and their minor drainages are very responsive to rainfall; thus, they are mostly seasonal with moderate to heavy flow during the rainy season and light to cessation of flow in the summer. Some flow continues in Kelsey Creek above Kelseyville throughout the year, but the other creeks do not maintain surface flow during the dry season. Flow in Adobe Creek and Highland Creek is regulated by operation of flood control reservoirs in Upper Big valley.

Kelsey Creek has a drainage area of about 23,800 acres. Average discharge for the 29 years of record is 76.0 cts. $(55,000$ acrefeet per year), with a maximum reported discharge of 8,800 cts. and a minimum discharge of 0.5 cts. Monthly and seasonal mean flows for Kelsey Creek near Kelseyville are shown in Table 7.

Surface, waters in Kelsey Creek near Kelseyville are characterized as calcium bicarbonate with a low boron content of $0.10 \mathrm{mg} / 1$. Although water in Kelsey Creek has some boron and salts, it is generally of excellent quality and is suitable for irrigation of most crops. Turbidity is sometimes a problem during high run-off periods. 
$\downarrow$

ELD VIEL. Enronmental Consutants

TABLE 7

KELSEY CREEK NEAR KELSEYVILLE

MEAN FLOW IN ACRE-FEET

\begin{tabular}{|c|c|c|c|c|c|c|c|c|c|c|c|c|}
\hline oct. & Nov. & Dec. & Jan. & Feb. & Mar. & Apr. & May & June & July & Aug. & Sept. & $\begin{array}{l}\text { Annual } \\
\text { Total }\end{array}$ \\
\hline 975 & 2,368 & 9.546 & 13,609 & 11,510 & 7.608 & 4,938 & 1,905 & 800 & 373 & 240 & 248 & 54,122 \\
\hline
\end{tabular}

PERIOD OF SOURCE: 1947-1971

SOURCE: USES

Highland Creek is gaged both above and below Highland Creek Dam. Above the dam, the drainage area comprises 12 square miles. Average discharge for 13 years of record is 22.9 cts. $(16,590$ acre-feet per year). Maximum reported discharge is $3,140 \mathrm{cts}$. and the minimum is no flow. Below the dam, the drainage area totals 14.2 square miles. The average discharge for 9 years of record is 27.2 cts $\quad(19,710$ acrefeet per year), with a maximum of $765 \mathrm{cts}$. and a minimum of no flow. Water quality analysis for Highland Creek below Highland Creek Dam. near Kelseyville completed by the U.S.G.S. is shown in Table 8.

TABLE 8

WATER QUALITY AMALYSIS

HIGHLAND CREEK BELOW HIGHLANO CREEK DAM.

NEAR KELSEYVILLE

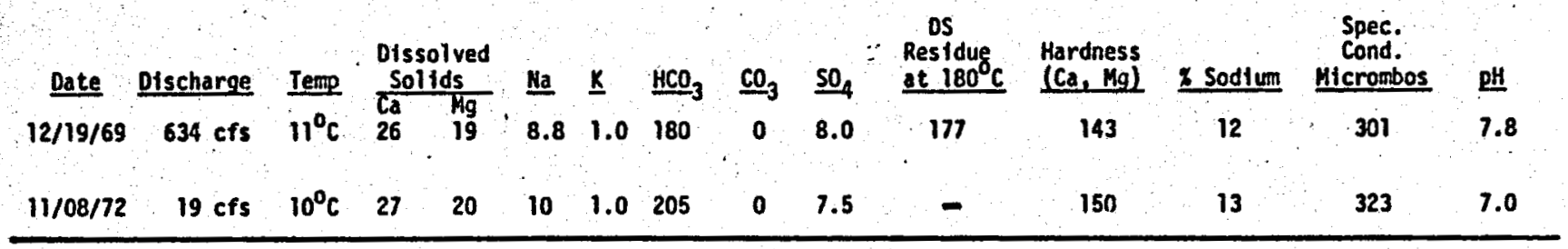

SOURCE: USGS

Units $\mathrm{mg} / 1$, where appropriate 
Adobe Creek near Kelseyville drains an area of about 6.5 square miles. Average discharge for 12 years of record is 12.8 cts. $(9,220$ acrefeet per year). The maximum reported discharge is $1,570 \mathrm{cts}$. , and the minimum is no flow for several months. Mean monthly and annual flows for Adobe Creek are shown in Table 9.

\section{TABLE 9}

MEAN FLOUS IN ADOBE CREEK

(ACRE-FEET)

\begin{tabular}{|c|c|c|c|c|c|c|c|c|c|c|c|c|}
\hline Oct. & Nov. & Dec. & Jan. & Feb. & Mar. & Apr. & May & June & July & Aug. & Sept. & $\begin{array}{l}\text { Mean } \\
\text { Annual } \\
\text { Total }\end{array}$ \\
\hline 129 & 335 & 1,799 & 2,691 & 2,137 & 1,056 & 724 & 148 & 19 & 0.5 & 0 & 5 & 9,045 \\
\hline
\end{tabular}

PERIOD OF RECORD: 1955-1971

SOURCE: $\mathrm{USGS}$

\section{THURSTON LAKE}

The Thurston Lake basin lies at an elevation of 1,420 feet about $1 \frac{1}{2}$ miles south of Clear Lake. The bas in is bounded by steep-sided slopes rising to elevations as high as 2,393 feet enclosing a drainage area of approximately 18 square miles. Thurston Lake's average surface area is about 354 acres. The lake level has remained relatively stable over the last few decades with high water about 20 feet higher than the mapped elevation.

Thurston Creek (ungaged) provides the major source of inflow to the lake. Surface flow is normally observed only after a storm, and water is seldom seen in the creek. 


\section{0

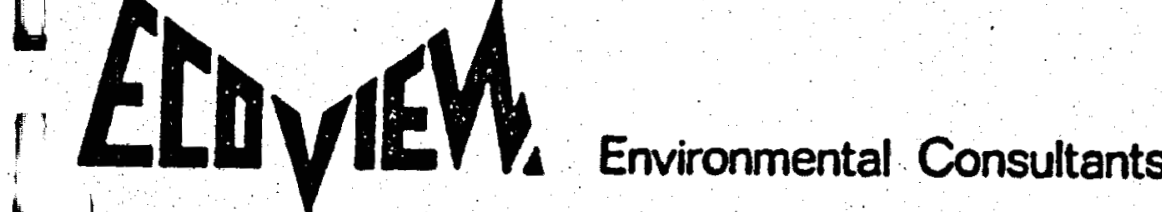

The Effects of Non-Electrical Uses

The impact of non-electrical uses on water quality may be significant unless stringent mitigations are enforced. Geothermal fluids must be reinjected into the reservoir or be reclaimed to remove harmful contaminants.

Livestock wastes need to be controlled so that their nutrients do not cause further eutrophication of Clear Lake or to underground aquifers supplying domestic water to residents of the area.

Similarly, careful disposal of manufacturing or processing wastes must be practiced to curb both eutrophication or contamination of surface or subsurface waters.

\section{THE VEgETATIION RESOURCE* $\therefore \cdots$}

Plant Communities

The majority of the Thurston Lake area is vegetated with chaparra1 dominated by four genera of shrubs; Quercus, Adenostoma, Arctostaphylos, and Ceanothus. The distribution of these is primarily determined by available soil moisture and exposure and secondarily by the chemical and physical characteristics of the soil and by disturbance from fire or human activity. The microclimatic differences between north-facing and south-facing slopes, particularly with regard to soil moisture, produces the most obvious species distribution patterns.

Three types of chaparral can be distinguished in the Thurston Lake area; mixed chaparral, chamise chaparral, and scrub oak/chamise chaparral. Mixed chaparral (cf. Biswell, et. al., 1952) is composed

* Source of this complete section "Environmental Impact Report Thurston Lake-Exploratory Project" VTH, 1976 pp. 28-29, 171, 33-40. 


\section{Environmental Consultants}

of approximately 10 to 15 species of shrubs, but is dominated by interior live oak (Q. wislizenii), manzanita (Arctostaphylos ssp.) and California lilac (Ceanothus ssp). It forms a very dense cover, with the oaks and other shrubs attaining heights of up to 15 feet. Mixed chaparral occurs on northerly-facing slopes and on other sites that have a relatively moist microclimate. Knobcone pine (Pinus attenuata) occasionally occurs in mixed chaparral as scattered small trees. It also forms dense stands of taller trees. These stands are considered as a separate type.

Steep south-facing slopes and other relatively dry sites are typically vegetated with chamise (Adenostoma fasciculatum) in almost pure stands. These shrubs are generally smaller than the mixed chaparral species, growing from four to six feet in maximum height. Depending upon the harshness of the site, cover ranges from moderately open to dense.

In the Thurston Lake area, transition between these two types of chaparral can be recognized in the Scrub Oak Chamise association. Both scrub oak (Q. dumosa) and chamise occur within the mixed chaparra 1 type but in relatively small amounts. As one moves from a mesic site to a more xeric site, the proportion of these two species increases and interior live oak and other species decreases. Thus, between the mixed chaparral and the relatively pure chamise, there is found a zone where scrub-oak and chamise are co-dominant.

Two tree-dominated communities occur within the Thurston Lake area Knobcone Pine and Digger Pine Oak. Knobcone "forests" occur as dense stands of trees on north-facing slopes. They have an understory of mixed chaparral species. Oak/Digger Pine woodland ( $Q$. kelloggi.i. Q. lobata, and P. sabiniana) is found on north-facing slopes around Thurston Lake. The trees are relatively large and form an open stand with a sparse understory of chaparral species. The Thurston Lake area contains a number of vernal pools. These are small, tempor- 


\section{ADVIE. Environmental Consultants}

ary ponds that form in depressions where drainage is poor. They fill after a rainfall and may last from one week to many months, during which time a distinctive plant and animal life develops and matures. Vernal pools are a unique habitat and contain species of plants that occur in no other habitat. As a result many typical vernal pool plants are classified as rare and endangered.

These same plant communities also occur on the flanks of Mt. Konocti; however, on the north face of the mountain and in the bottom of a narrow valley near Sugar Loaf Mountain, valley oak woodland and black oak woodland also occur. West of the recent volcanics on the slopes of Konocti and the alluviums of Big Valley, there occurs a narrow belt of blue oak woodland and savannahs. The understory of these communities is mostly introduced annual grassiand, but in isolated areas native herb-grass associations are found.

None of these communities with the exception of the flats are particularly unique or are of such limited distribution that a loss of a portion for development is significant from the standpoint of vegetation itself. Soil erosion and wildlife habitat may be locally significant, however.

Rare and Endangered Plants

Populations of three endangered plant species are known to occur in the vicinity of Thurston Lake. All are on the list of species proposed for consideration as threatened species (Fed. Reg., I July 1976) and on the California Native Plant Society (CNPS) list of very rare and rare and endangered plants (W. Robert Powe11, 1974, Inventory of Rare and Endangered Vascular Plants of California. Special Publ. No. 1, California Native Plant Society). The plants are Lasthenia burkei, Navarretia pauciflora, and Parvipedum leiocarpum. Maps . of the CNPS show colonies of all species on Manning Flat. All of the 


\section{Environmental Consultants}

plants grow in moist places or vernal pools. Specimens could occur in vernal pools at the upper end of Thurston Lake.

\section{The Effects of Non-Electrical Uses on Vegetation}

Since hot water is the most probable resource, little direct effect of effluents are to be expected assuming a closed system and reinjection or an effective water reclaimation system.

The other important aspect is the physical removal of vegetation by large scale operations. The interruption of large areas of brush and woodland by low fire load cover or non-flamable installations, such as roads or building areas, may be a considerable benefit to long range fire control and change in the vegetation type in many places.

\section{THE FAUNAL RESOURCE *}

Wildiife in the vicinity benefits from a mild climate and the diversity of habitat provided by the chaparral, pine forest, oak woodland, grassland, and riparian plant communities. The various communities are scattered throughout the area and enhance wildlife populations by providing a variety of "edge" area and habitat types.

Plant community distribution and structure are extremely important in determining the composition and density of fauna (Odum, 1971; Sma11, 1974). Each plant community serves two groups of wildlife, residents and transients. Resident species spend all or most of their time within one vegetation type. It supplies all their ecological requirements, and they are not compelled to leave. Transient species divide their time between different habitats, seeking forage in one type, cover in another, etc. Belted kingfishers fulfill their

* Source: VTN, 1976. 
needs within the riparian community, and the chaparral supplies all requirements for the dusky-footed woodrat. Mourning doves (absent from this area in January) may find it necessary to feed along roads and in grassiand, water in riparian areas, and roost in woodland. Areas where different habitats adjoin fulfill more requirements for wildlife and usually have higher populations.

Important game animals of the overall Lake County region include Columbian black-tailed deer (Odocoieus hemionus columbianus), California quail (Lophortyx californicus), mourning dove (Zenaidura macroura), band-tailed pigeon (Columba fasciata), gray squirrel (Sciurus griseus), cottontail rabbit (Sylvilagus auduboni), and several species of waterfow1. California quail are common birds of the region. They are notably birds of cover edges and do not reach high population levels in large areas of thick brush (Edminster, 1945). Quail feed primarily on forb and grass seeds (Summer, 1935; Glading et. al., 1940; McLean, 1930). The continuous canopy of thick brush causes deep shade and prevents the growth of prime browse species.

The most suitable quail habitat that Summer (1935) found supported from 1.1 to 3.9 quail per acre. Emler (1939) studied a population on poor habitat near Davis, California and found the highest density of the year to be 0.15 birds per acre, or approximately 7 acres per bird.

The mourning dove is a migratory bird that frequents most habitats except deep forest, marshes, or great expanses of open territory. The birds are quite mobile and often have a large range that includes forage, water, and roost areas at widely separated locations. They feed almost exclusively on grass and forb seeds (Martin et. a1., 1951). 
Almost any area of the United States supplying these needs will support doves (Edminster, 1954). Because doves are migratory, the concept of density is difficult to apply except during breeding season. Density varies so widely with habitat that most figures are meaningless.

Gray squirrels prefer open pine and oak woodland where they feed on acorns and other seeds. Populations vary from 0.1 to 2 squirrels per acre (Burt and Grossenheider, 1952). Good habitat is available . in the region but only one squirrel was sighted (on Roundtop Mountain) during the field investigation.

Important non-game mammals are the coyote, bobcat and ground-squirrel. Coyotes and bobcats are retiring and none were sighted. Coyote tracks and scat are encountered in all habitat types. Bobcats are reported as fairly common by residents of the area. Black bear may occur, but are probably transient (Branston, personal communication).

Varied habitat in the vicinity of the study area attracts a good variety of bird life. During January some of the summer transient birds are absent, while others that winter in the area are extremely abundant. Robins were the most conspicuous bird during the field study. All wooded areas had dense, if perhaps transient, populations. Each type of habitat has a slightly different bird populations structure. The most common visible birds of the area are Oregon juncos, rufous-sided towhees, wrentits, and scrub jays. Scrub jays, red-tailed hawks and many others range different habitats. Thurston Lake itself supports an interesting avifauna that includes an osprey, great blue herons, belted kingfishers, double crested cormorants and a variety of other riparian or aquatic birds. Red shafted flickers and acorn woodpeckers are abundant in the oak woodland along the northwest end of the lake. Poikilothermic (cold blooded) reptiles and amphibians are generally inactive during cool periods and none were seen during field study. Habitat is adequate for both reptiles and 


\section{Environmental Consultants}

amphibians, and they are undoubtedly in the area.

The heavy cover provided by chaparral is an asset to rodents and other small vertebrates. The canopy protects these small animals from airborne predators (hawks and owls) while the thicket of stems and low branches permits escape from coyotes or bobcats. Several.nests of the dusky footed woodrat were found in the area, and a pattern of burrows attests to the presence of many other rodents. The most common rodents in addition to the dusky-footed woodrat were the brush mouse, western harvest mouse, and white-footed mouse (Wirz, 1973; Burt and Grossheider, 1952).

Several stands of knobcone; Digger pine, and oak woodland are near enough to Thurston Lake to affect its ecology. The lowland area around the west and northwest portion of Thurston Lake provides an edge area where chaparral grades into oak woodland. The edge effect (0dum, 1971) and availability of water support important wildlife habitat where California quail, black-tailed deer, and probably gray squirrels are abundant. The oak woodland supports a diverse avifauna that includes many species. Thurston Lake supports an osprey and several other species. Typical residents of these habitats are discussed by Smal1 (1974) and Wirz (1973).

\section{Aquatic Biology}

Aquatic resources in the vicinity include Thurston Lake and Thurston Creek. The naturally formed Thurston Lake has no known surface outlet.

Thurston Creek is an intermittent stream that rises in several. springs southwest of Thurston Lake. It flows to the west across Soda Bay Road and then drains eastward to Thurston Lake. Its length is 
approximately 12 miles. In January, 1976, the stream flow was \pm 1 cfs (cubic feet per second) at Soda Bay Road. The stream apparently goes into the groundwater, as the section near Thurston Lake was dry. Along the western portion of the stream the presence of cattails, mayfiy nymphs and caddis larvae suggests that the stream flows persistentiy, or at least supports residual pools. The stream is clear, quite shallow, and has a thick growth of Myriophyllum sp. and other aquatic plants. Several tributaries drain flats where erosion has cut through alluvium into underlying volcanic materials. The tributary draining Manning Flat has eroded a trough-shaped gully that is approximately $100^{\prime}$ wide by $100^{\prime}$ deep and approximately one mile long. Most of the material removed by erosion was transported to Thurston Lake. As stream water enters the lake it loses velocity, and the suspended materials settle to the bottom. Accumulated depositional materials have formed a large delta at the upper end of the lake and have considerably aitered the bottom structure and contours. Much of the ashy material remains in suspension, giving the water a cream colored appearance. The material reduces transparency and impairs the lake's potential as a fishery resource. Local residents state that the lake contains bass and catfish. Signs of angular use are obvious at the eastern end of the lake. Baker (personal communication) reports that the lake contains largemouth bass (Micropterus salnioides), white catfish (Ictalurus catus), brown butlhead (Ictalurus nebulosus), Sacramento hitch (Lavinia exilicauda), and Sacramento perch (Archoplites interruptus). Because the lake is private, California Department of Fish and Game has limited information. They consider it to be a marginal fish lake (Baker, personal communication).

The vernal pools in the area contain water following major storms. These ponds are interesting because of their unique crustacean fauna. The most important group being the "phyllopods", consisting of 
fairy shrimp, clam shrimp, and tadpole shrimp (Orders Anostraca, Chonchostraca and Notostraca). These organisms are unique to temporary waters throughout the world; and are rarely found in permanent lakes. Phyllopods are particularly adapted to the vernal pool habitat, having eggs that can withstand severe drought or freezing. Other vernal pool crustacenas include copepods (Order copepoda) water fleas (Order cladocera), and seed shrimp (Sublcass ostracoda). All of these organisms pass the dry season as an egg or cyst that can withstand dessication, sometimes for many years, and hatch rapidly upon rewetting. Certain genera of these animals are common to vernal pools in many different regions of the world (Pennak, 1953).

Rare and Endangered Species

Three rare or endangered wildlife species could occur, the southern bald eagle (Haliaeetus lencocephalus leucouphalus), the peregrine falcon (Falco peregrinus anatum), and the yellow-billed cuckoo (Coccyzus americanus). The bald eagle frequents large lakes and has been reported in the area (Buckman, personal communication). Peregrine falcons are rare, with less than 10 pairs nesting in California in 1970 (Calif. Dept. Fish and Game, 1972). Peregrines have been reported in recent years as frequenting Cobb Mountain. They were reported from Mt. Konocti in 1940. None are known to frequent the study area at this time. The yellow-billed cuckoo is reported to occur in Anderson Marsh at the southeast end of Clear Lake. The yellow-billed cuckoo is not included in the U. S. Fish and Wildlife Service list of threatened or endangered species (September 1975). However, it is listed as rare by the California Department of Fish and Game. Anderson Marsh is approximately three miles east of Thurston Lake. 
ENVIRONMENTAL REPORT

STUDY AREA III

COLLAYOMI VALLEY - FORD FLAT AREA

Prepared under Subcontract to Geonomic, Inc. as part of Phase Zero of the ERDA grant "Alternative Agribusiness and Industrial User for Exhaust Heat from Geothermal Waste Fluid, Lake County, California".

Submitted: May 27, 1977

James A. Neilson, Ph.D. President 
Environmental Consultants

\section{TABLE OF CONTENTS}

INTRODUCTION . . . . . . . . . . . . . . . . 1

I. STUDY AREA III GENERAL ASPECTS

Area Characteristics .............. 1

Resource Status .............. 4

Area Capability ....................... 7

Environmental Constraints ......... 8

II. THE AIR RESOURCE - STATUS \& QUALITY

Climate ........................ 8

Air Quality .......................... 13

Effects of Nonelectrical Development ....... 13

III. THE WATER RESOURCE - STATUS \& QUALITY

Hydrology .......................... 14

Water Quality .................. 17

Effects of Non electrical Development ...... 20 
Environmental Consultants

\section{LIST OF FIGURES}

FIGURE 1 MAP OF GENERAL AREAS . . . ....... 2

FIGURE 2 FORD FLAT IN RELATION TO GEOTHERMAL FIELD $\ldots \ldots$

'FIGURE 3 EVAPOTRANSPIRATION CURVE ......... 11

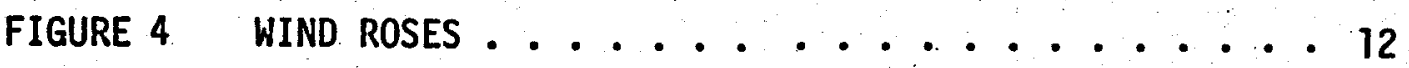

\section{LIST OF TABLES}

TABLE 1 MOSTLY AVERAGE PRECIPITATION ........ 10

TABLE 2 TEMPERATURE DATA ........... 10

TABLE 3 PUTAH CREEK STREAM FLOW ............ 16

TABLE 4 COLLA YOMI VALLEY WATER QUALITY ....... 17

TABLE 5 COYOTE VALLEY WATER QUALITY ....... 17

TABLE 6 PUTAH CREEK WATER QUALITY .............. 18

TABLE 7 DRY CREEK WATER QUALITY $\ldots \ldots \ldots$

TABLE 8 DRY CREEK WATER QUALITY ......... 19 
The Collayomi Valley is a long narrow valley within the Putah Creek watershed. It is the largest single block of flat land within three miles of a developed geothermal resource anywhere in Lake County. Ad- jacent areas of potential use extend into the hill country of Gunning Creek (Ford Flat) and limited areas of the Dry Creek drainage. Middletown lies near the center of the valley at the confluence of St. Helena and Putah Creeks. The summer home - retirement community of Anderson Springs lies near the head of the main valley in the upper portion of Putah Creek near the junction of Bear Canyon Creek and Gunning Creek. Because of the sharp divergence of character, this study unit can be divided into at least two divisions: The Collayami Valley (III-A) and Ford Flat (III-B) (Figure 1).

\section{STUDY AREA III GENERAL ASPECTS}

\section{Area Characteristics}

Area III-A

The broad flat Collayomi Valley (III-A) covers approximately five square miles that can be adapted to geothermally oriented projects and their ancillary industries and activities. The orientation of the valley generally follows the base of the Mayacmas Mountains; two miles is the average distance of the valley to the crest, where the center of current geothermal development lies. State Highway 29 passes along St. Helena Creek to Middletown and turns northeast to Lower Lake. Highway 175 connects Middletown with Cobb Mountain resorts and Kelseyvilie.

Land use within the valley is largely open space and agriculture. The soil is a stony loam of relatively poor quality with livestock, wainuts, and grapes the principal products. Some oat-vetch hay is raised, while irrigated pastures and a few alfalfa fields lie along Putah Creek. 


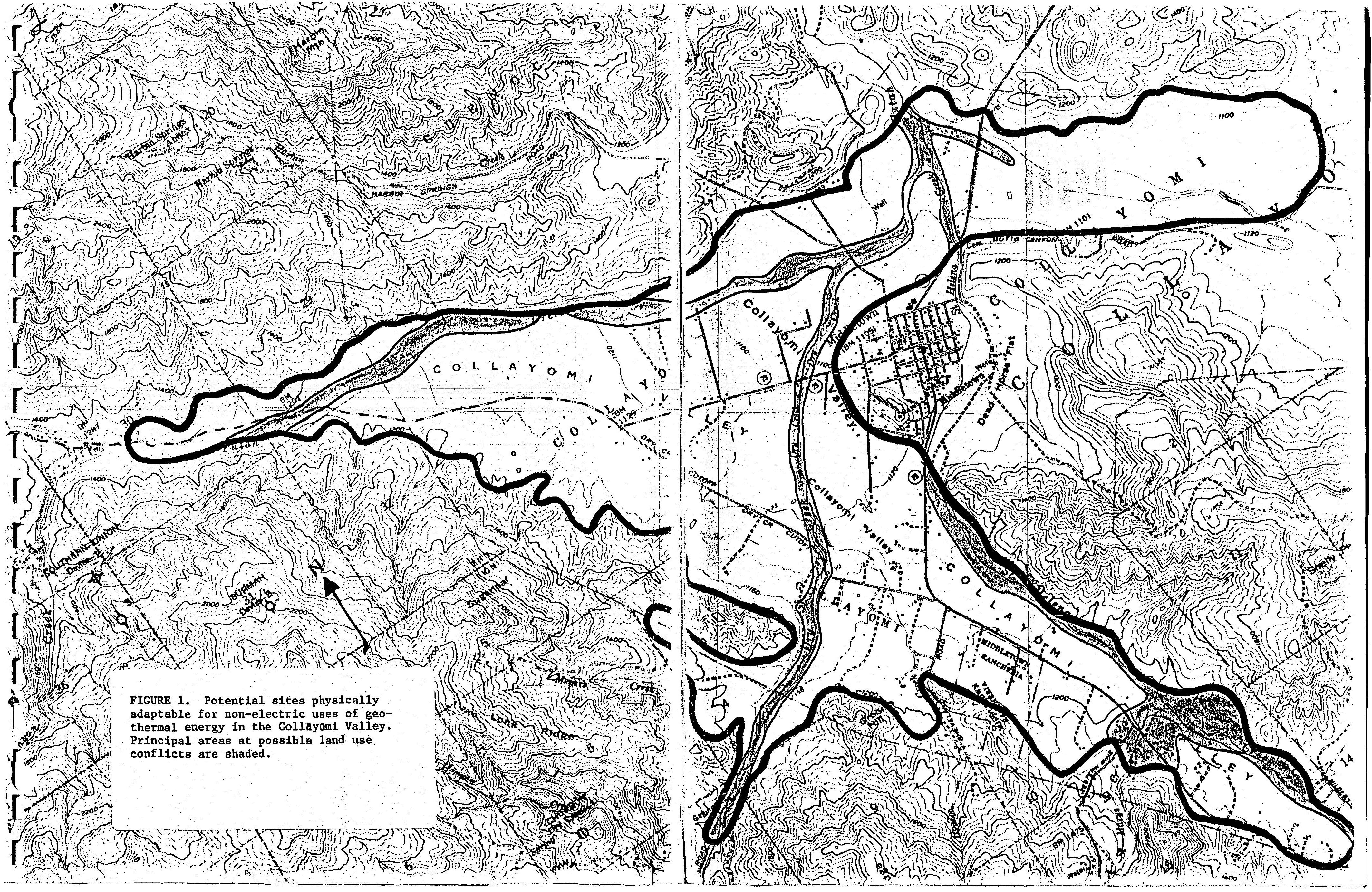




\section{Environmental Consultants}

The valley's natural vegetation is predominantly valley oak savannah or mixed oak woodland. Yellow pine-oak woodland occur on the deeper soils at the foot of the Mayacmas. Chaparrals, oak woodlands, pineoak, madrone woodlands and fir-black oak woodland communities clothe the surrounding hillsides. Riparian vegetation is well developed along all water courses.

The Joan Haman Dole Memorial Wildiife Sanctuary on Rabbit Hill (10cated on the southern outskirts of Middletown) and the lower reaches of Dry Creek have been nominated by the Natural Areas Coordinating Council as wildlife and wildflower preserves. Another sensitive area is the scenic corridor extending from Robert Louis Stevenson State Park at Mt. St. Helena through the valley to Cobb Mountain and beyond.

Population density is greatest around Middletown (cf. Socio economic report), but clusters of houses and small farm residences are scattered throughout the whole valley. Several large ranches, extending to near Middletown, are located in the northern portion of the valley.

Area III-B

In sharp contrast to Area III-A is the Ford Flat area (III-B) located above Anderson Springs and at the southeastern foot of Cobb Mountain near the head waters of the Gunning Creek drainage. These flats are actually-a series of earth slumps or low hills which have formed small areas ( 5 to 15 acres) of low relief at various elevations in the foot hills of the Mayacmas Mountains and Cobb Mountain.

The uppermost ( $\pm 2500^{\prime}$ elevation) and one of the largest flats is known as Ford Flat located within 300 meters of Aminoil's new well PDC \#1;

it resembles a small basin. At one time an orchard and berries were raised here; today a series of ponds and apple trees still survive. A ditch from Gunning Creek supplied water to the ponds. Fish may have been cultured in them at one time. Other flats off to the 


\section{Environmental Consultants}

east support remnants of small orchard plantings, grassland, or second growth yellow-pine. Figure 2 shows the relationship of these flats to Aminoil's geothermal wells and to P. G. \& E. Power Unit 13. Without doubt another generator complex will be developed in the vicinity.

Land use in the area is forest production, recreation; and geothermal steam for electrical generation. Large amounts of timber were harvested in 1973; however, because the regeneration potential is high, recovery under local conditions of high rainfall and rich soil should be good. The soil is generaliy a sandy loam, very deep and well drained. Low relief hilltops and ridges suitable for development support a lateritic gravelly loam.

The vegetation is second growth yellow-pine forest except on Ford Flat itself; here high moisture and locally poor drainage maintain a black berry-sedge-grass community that appears to be largely of anthropogenic origin. Manzanita, black oak, dogwood and some Douglas fir occur as mid-seral communities to the Coastal Yellow Pine forest type that represents the climax community of the area. The rare plant Lupinus sericatus occurs in small stands here and there on disturbed sites and as an herbaceous understory member under pine stands. Drainage flows to Gunning Creek, a portion of the water supply for Anderson Springs.

Although a part of the scenic corridor passes through the Cobb Mountain area, the flats are remote from the highway and appear as unclassified zones in the Lake County General Plan.

Resource Status

Very little land in Collayomi Valley is leased for geothermal purposes. The immediate future's potential geothermal source may be only steam condensate as a by-product from electrical generation. At least three potential power complexes are being or plan to be developed between 


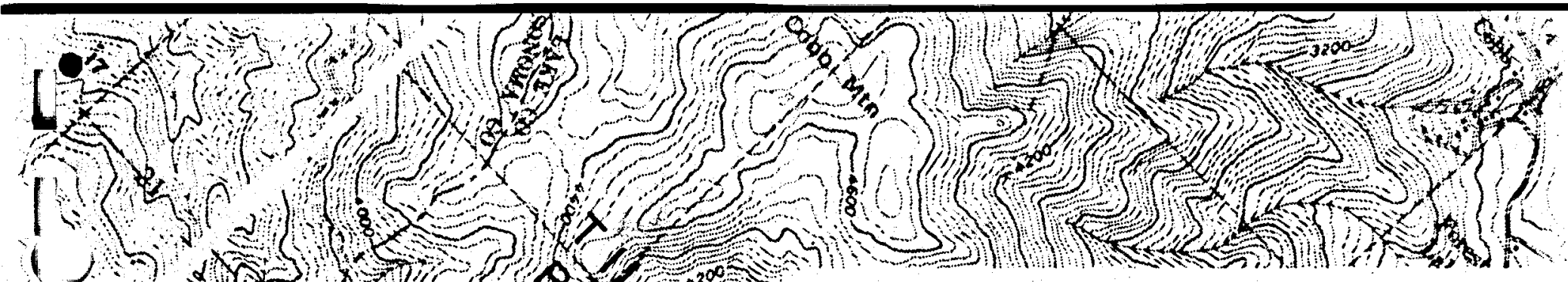

\section{Lo.}

L.

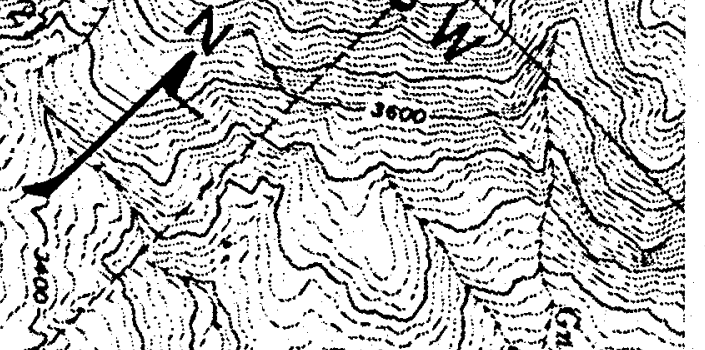

FIGURE 2. Potential sites in the Ford FlatAnderson Springs Area adaptable for nonelectrical uses of Geothermal Energy. Dots represent producing. Geotherma1 wells. Square is P.G. \& E. Unit 13 power plant under construction. Units 18 and 19 may be sited in the vicinity also. Areas of land use conflict are Indicated by shading.

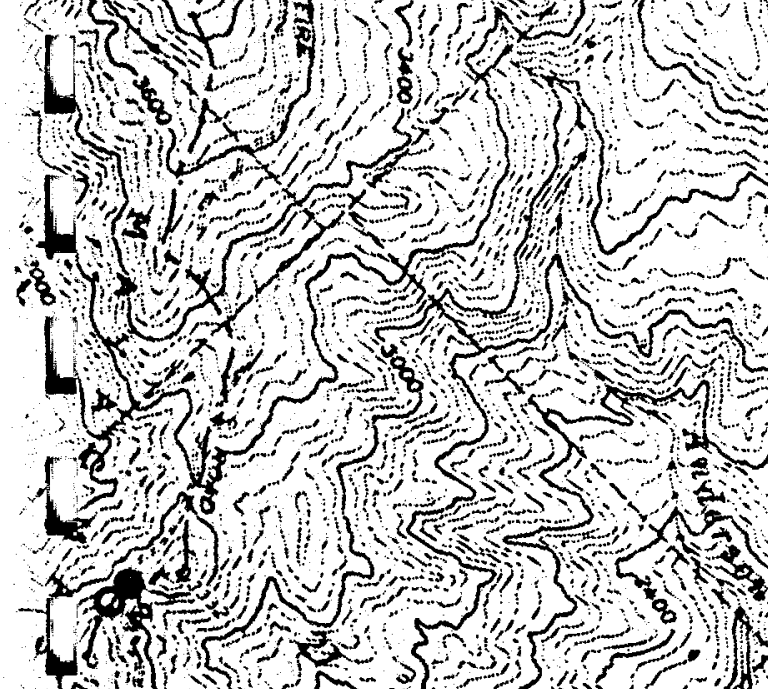

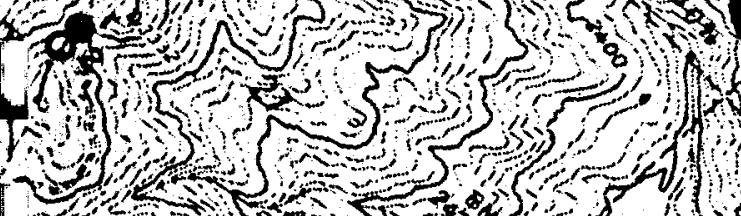

M!

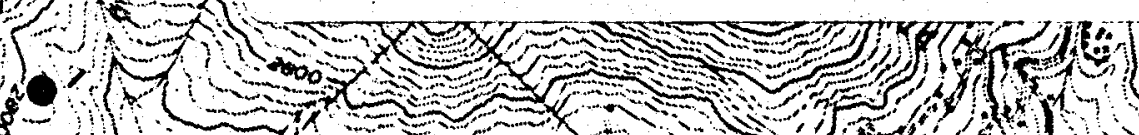

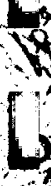

列

t.

.

(3)

西

(3)

(5)

(n)

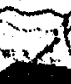

20

solas

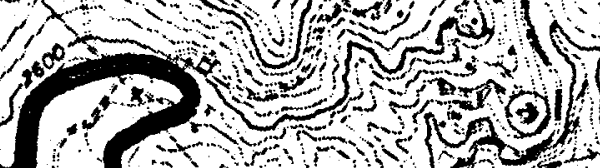
(3)

S

S1)

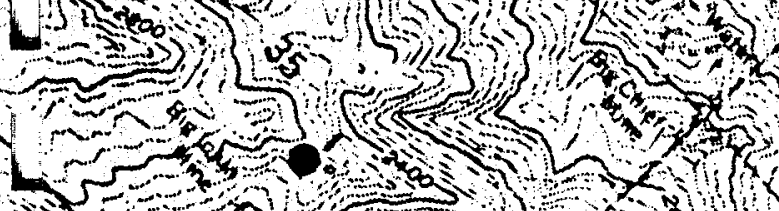

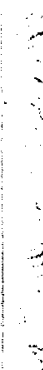

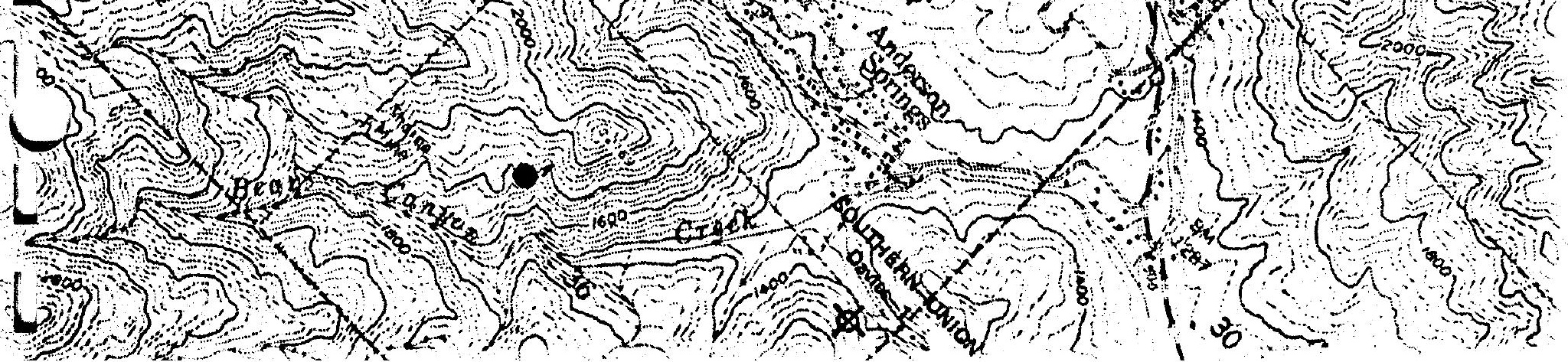

00
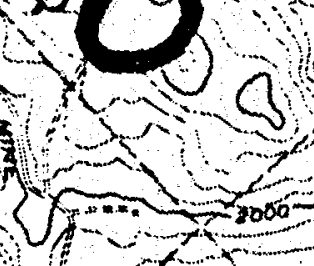

Jin

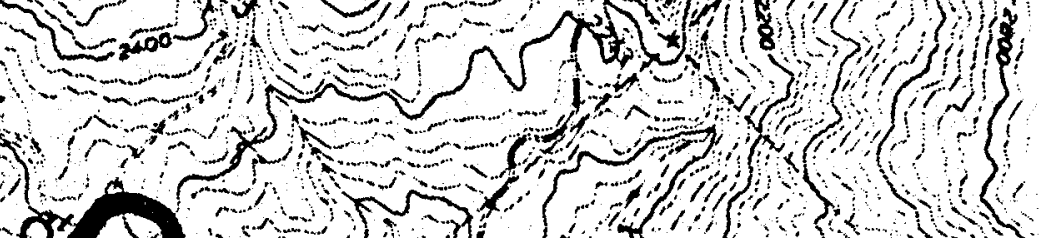




\section{Environmental Consultants}

Cobb Mountain and Dry Creek. Other wells are being drilled or have been applied for by Shell, Thermogenics, Cherron, and Union 0 il Company. No tapable geothermal sources are evident in the valley itself. The valley itself demarks the Franciscan Formation from the Lake County Volcanics, and marks the putative division of steam to the west and hot water to the east. The validity of this hypothesis must await future development and exploration. In short, the consideration of geothermal uses for the area may be rather premature, yet potential valley land use is by far the most adaptable of any area in Lake County, especially if a hot water resource is developed in the Big Canyon or Boggs Mountain area nearby.

The most immediate short range potential is to use the valley as a heat sink for cooling steam in place of or supplemental to condensers at the generators. This may involve more energy and cost than non-electrical applications can afford because of the distance and elevation differential. The potential for drilling hot water or steam wells of lower temperature than that profitable for large scale electricity generation should not be overlooked for any of this area. While the success of Aminoil's well in Long Valley to the east was nil, careful geotechnical searching may reveal sources that can be tapped for non-electric uses. It may behoove Lake County to enter into lease agreements with all unleased land in this area with the objective of preserving this land for development of industries operated on a municipal or local area basis for local application. Local control and local benefits may well succeed where typical speculative development by 011 companies would encounter severe opposition. Long term E.R.D.A. guaranteed loans for both drilling and construction of use facilities might provide the funding necessary.

The development of the resource in the Ford Flat area is currentiy underway by Aminoil, Inc. Two ridge top wells just east of P.G. \& E.'s Unit 9 and 10 power plant mark the western boundary. The Ford Flat well, 


\section{Environmental Consultants}

proven in April, and a third well, one mile to the east, established the remaining general parameters of the field. Aminoil is now preparing to site other wells and press for full field development.

Area Capability

Clearly the most valid uses for Area III-A are those devoted to agribusiness, especially greenhouse operations and livestock feed production. Such operations are immediately compatible with existing range beef production. Ancillary operations connected with processing and preserving agriculture products such as suggested for High Valley Creek and Sulphur Bank - High Valley areas would be useful. Cut-flower operations may have a distinct advantage here, because room is available for an airport to provide distant and rapid transport. Truck transport is possible, but not as attractive because Highway 29 between Middletown and Yountville is narrow, tortuous, and congsted. In the event suitable quantities of energy are discovered, nearly any manufacturing or processing could be adapted to the area if the economics of raw material transport and products could be made favorable.

The area around Ford Flat (III-B) has limited usefulikess because of difficult access and its remoteness from settlements and labor sources. Nevertheless, if favorable economics proved out, agribusiness and commercial processing could be developed, but the products would need to be a high value, low bulk commodity. While the land area is relatively limited, up to 100 acres of scattered operations could be sustained. Heat transport would be much more favorable than for the Collayomi valley because it is immediately proximal to or, perhaps, in the midst of a geothermal field. The flats probably could not sustain geothermal drilling pads because of soil instability, but probabiy could support the light-weight construction of most nonelectric uses. 


\section{Environmental Consultants}

\section{Environmental Constraints}

Since the most immediate heat source in the CollayomiValley is dry steam or condensate, safety in transport to the use site is a most important factor. If condensate is used, rigid safety standards must be adopted to minimize effects of line breaks and spills that would affect soil and water quality. If condensate is not returned to the generating plant, reinjection wells must be drilled in the valley, unless the water could be reclaimed. However, the excessively high level of contaminants may well preclude this possibility. These problems may be avoided by the use of heat exchangers at the power plant.

The chief constraints for the Ford Flat area are water quality maintenance and protection of the forest habitat. Careful planning of all installations, site engineering, drainage, waste disposal and its control, together with the problems of condensate or steam control are major factors; but all can be handled with current technology. Economic evaluation of all potential uses must be paramount to overcome transport problems.

Changes in land use should not be a major constraint for either Area III-A or III-B. Only a small percentage of the Coll ayomiValley floor would be used, even for high volume production. In the Ford Flat area, as long as development is limited to low relief sites and aesthetically acceptable development should not be objectionable. Considerable care must be exercised to avoid unnecessary exposure to vistas afforded along Highway 29 and resort and recreation areas.

\section{THE AIR RESOURCE- STATUS AND OUALITY}

Climate

The climate of the Middletown area is a Mediterranean type with warm 


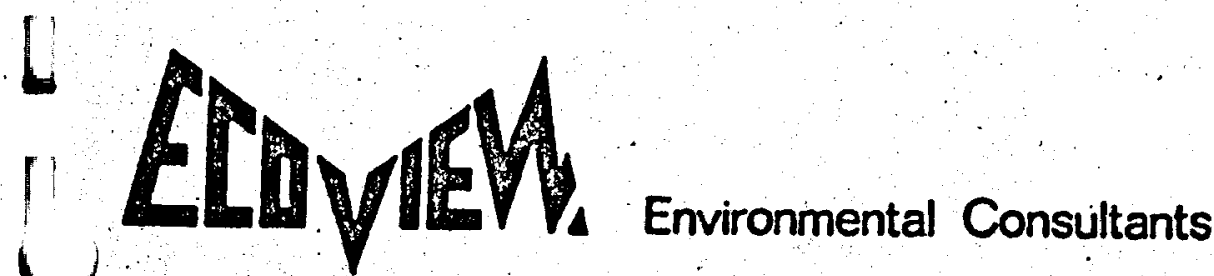

summers and mild winters. The sunmers are mainly influenced by a high pressure system which lies off the California coast. This high pressure system forces polar air masses to the north causing hot, dry summers. During winter months, this high pressure cell shifts to the south allowing frontal systems to pass over the state.

Average annual precipitation recorded at Middletown is about 46 inches (Table 1). About two inches of snow falls annually, but rapidly meits. Approximately $95 \%$ of this precipitation falls during the period of October through April. 


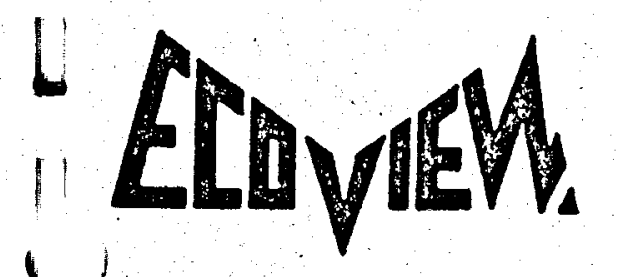

Envronmental Consultants

TABLE 1. MIDOLETOWN

MONTHLY AVERAGE PRECIPITATION IN INCHES

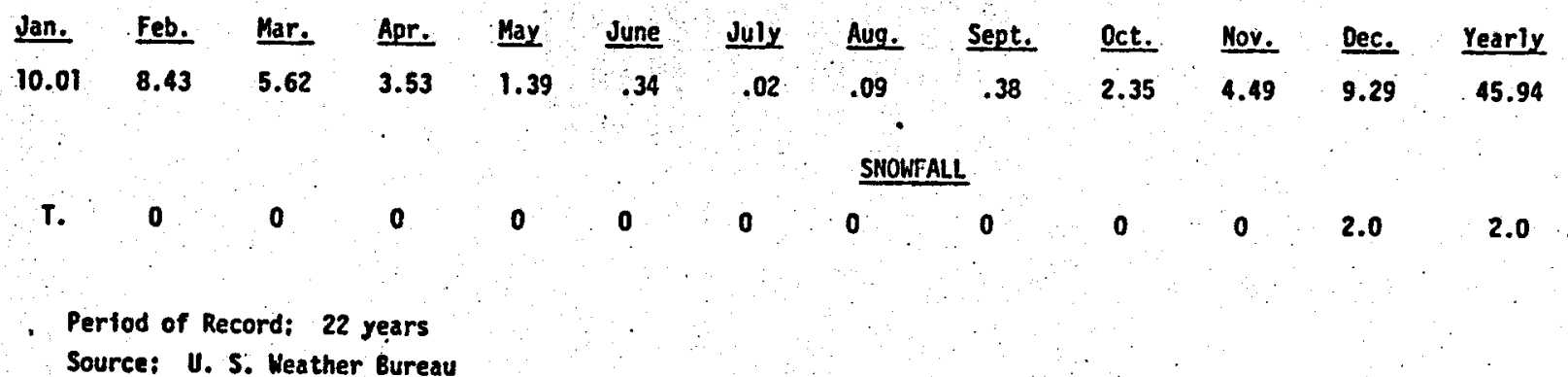

Limited temperature data is available for the Middletown area. The general temperature regime for the region produces average temperatures in January of about $400 \mathrm{~F}$ and for July, about $70^{\circ} \mathrm{F}$; maximum and minimum temperatures range between $15^{\circ} \mathrm{F}$ and $110^{\circ} \mathrm{F}$ (Table 2).

\section{TABLE 2. Temperature Data Middletown -- Guenoc Ranch}

\begin{tabular}{lcc} 
Month & \multicolumn{1}{c}{$\begin{array}{c}\text { Temp. Max. } \\
\text { JF }\end{array}$} & $\frac{T}{\text { Temp. Min. }}$ \\
\cline { 2 - 3 } & 62.9 & 29.3 \\
February & 64.2 & 36.5 \\
March & 73.5 & 40.1 \\
Apri1 & 73.1 & 36.9 \\
May & 84.7 & 43.8 \\
June & 96.8 & 50.1 \\
July & 100.9 & 55.6 \\
August & 102.2 & 51.8 \\
September & 90.3 & 43.3 \\
October & 75.7 & 42.6 \\
November & 64.9 & 35.2 \\
December & 52.8 & 26.3
\end{tabular}

Source: Environmental Impact Report, Guenoc Ranch, 1975. J. B. Gilbert \& Associates. 


\section{Environmental Consultants}

Beginning in October, frosts usually occur; occasional hard freezes continue into April.

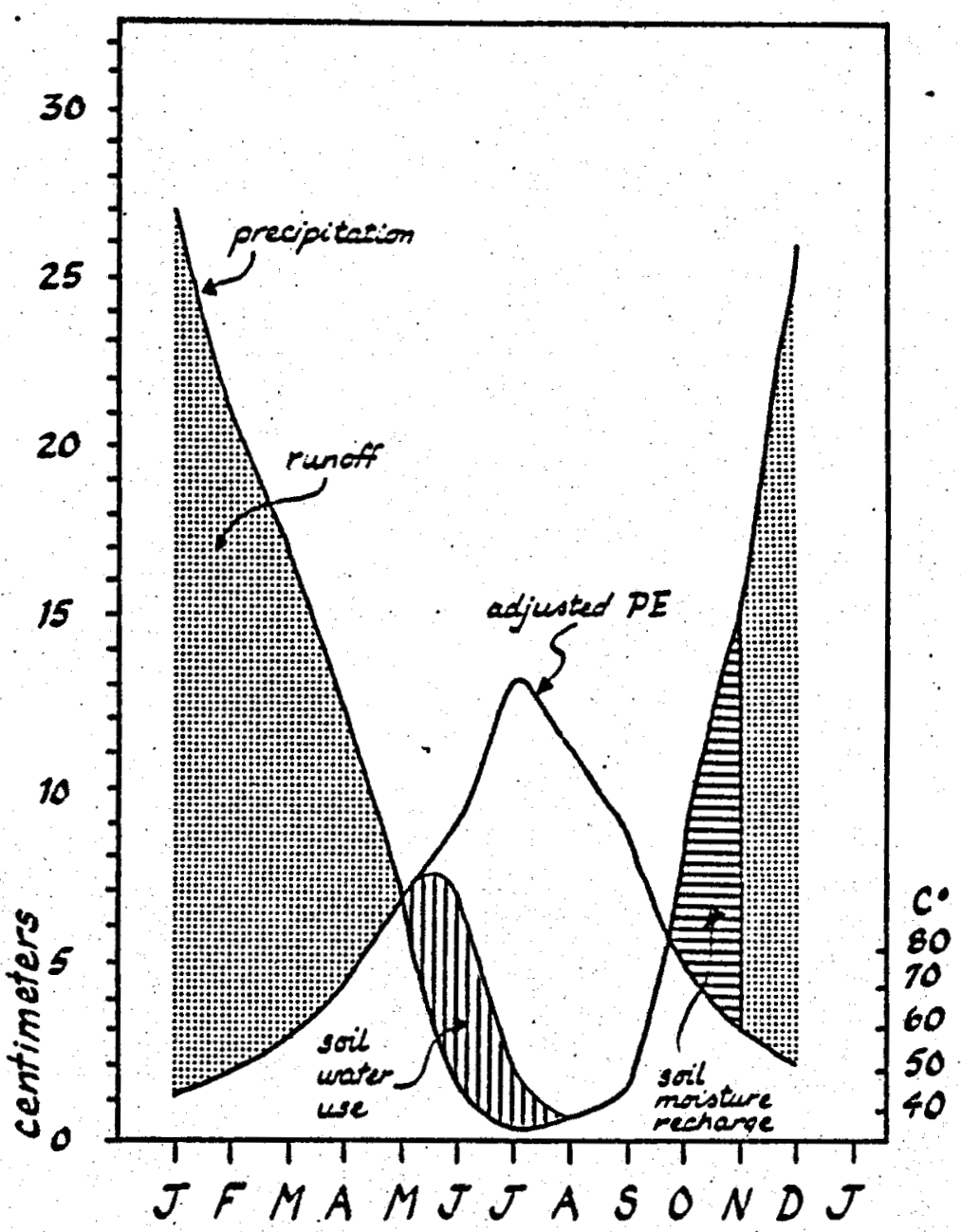

Figure 3 . The relationship of precipitation regime and temperature regime to the growth requirements of plants. As soil moisture dwindles, plants, requiring more water than is available, show drought symptoms. As a rule, potential evapotranspiration drops to zero in January when temperatures are too low for either growth or extensive evaporation. Growth in this part of California occurs during the narrow period when warm temperatures coincide with adequate moisture. 
Wind patterns are generally typical of the regional situation. Figure h's wind roses are based upon afternoon averages for the four seasons as well as annually. Southerly winds are predominant at all seasons and almost exclusive during summer months with average speeds sufficient to ensure atmospheric mixing. During the winter season, wind patterns show strong components primarily from the south and southwest and secondarily from the north and northeast. The maximum observed wind velocities, on the order of 25 to 30 miles per hour, are usually associated with winter storms. Periods of calm occur throughout the year, but are most frequent during winter months. On an annual basis, periods of calm occur less than $5 \%$ of the time.

Air Quality

The California Air Resources Board conducted a short-duration (April 15, 1975 - May 12, 1975) monitoring of ambient air at Middletown. The contaminants monitored included ozone, carbon monoxide, nitric oxide, nitrogen dioxide, total hydrocarbons, methane, non-methane hydrocarbons, and coefficient of haze. California ambient air quality standards for all contaminants monitored were not exceeded during the monitoring period.

Effects of Non electrical Development

The precise effect of nor electrical development projects on air quality is difficult to assess without knowing whether condensate, geothermal hot water, or heat exchange fluids are to be used. Condensate contains considerable $\mathrm{H}_{2} \mathrm{~S}$ in solution and most steam and hot water contain the gas as well. If the system is completely self-contained then only spills or line breaks will affect air quality. Any exposure of fluids to the atmosphere will yield $\mathrm{H}_{2} \mathrm{~S}$, but at this time its assessment is not reliable. At worst, $\mathrm{H}_{2} \mathrm{~S}$ levels might exceed permiss ible standards in some local areas, but unless non electrical development is unusually 


\section{$b$ \\ Environmental Consultants}

extensive the total area affect would be small and localized. If water is used as a heat exchange medium, then no effect from the geothermal end need be expected. If hydrocarbons are used, then line breaks and spills may well be a serious factor.

Air quality effects and concommitant aesthetic effects from the various applications must be taken on a case-by-case basis. Cattle feed lot operations could be significant from dust and odors, however, proper management in the cascade use systems would reduce or eliminate such affects entirely.

\section{THE WATER RESOURCE - STATUS AND QUALITY}

Hydrology

Collayomi and Long Valleys are.arms of the same depression in the headward part of the Putah Creek drainage. Collayomi Valley, the larger of the two, includes an arm that extends southward along St. Helena Creek. Middletown is the central part of the valley. Three principal streams - Putah Creek, Dry Creek and St. Helena Creek - have their confluence in coll Valley. The three streams drain about 60 square miles of watershed. Of this area, the alluvial plain comprises about 4 square miles. Long Valley, which joins Collayomi Valley north of Middletown, has a drainage area of about 10 square miles with an alluvial plain of about 2.75 miles square. Perennial streams do not flow into Long Valley.

The California Department of Water Resources (1975) estimates that the average yield of wells in Collayomi Valley is 500 gallons per minute (gpm) with a maximum yield of $1200 \mathrm{gpm}$. Depth to the water bearing zone is 10 to 100 feet. Ground water storage capacity is about 29,000 acre-feet (AF) with a usable capacity of 7,000 AF. Ground water in the valley has been moderately developed for domestic, irrigation, and stock use. A potential for moderate additional development is indicated. 


\section{Environmental Consultants}

Coyote Valley lies about four miles northeast of Middletown and is separated from Collayomi and Long Valleys by a ridge. Putah Creek cuts through this ridge in a narrow canyon, enters Coyote Valley at its northwest end and discharges at its eastern end. The valley, which trends southeast, is irregularly shaped, about five miles long and about two and a half miles in maximum width. The total drainage area is about 42 square miles; alluvial plain comprises. about six square miles.

The California Department of Water Resources (1975) estimates average well yield in Coyote Valley at $500 \mathrm{gpm}$ with a maximum reported yield of $1200 \mathrm{gpm}$. Depth to the water bearing zone varies from 10 to 100 feet. The estimated ground water. storage capacity is 27,000 AF, the usable capacity is about 7,000 AF. Ground water in the valley has been moderately developed for domestic, irrigation, and stock use. The estimated 1966 pumpage totalled 2,330 AF. The estimated safe ground water yield is 5,000 AF yearly; thus, there is a potential for moderate additional development.

The principal source of water supply in the upper Putah Creek drainage originates from direct precipitation on the area. Storms passing over the basin deposit their heaviest precipitation along the crest of the ridge defining the western boundary of the basin. As the storms progress eastward, depth of precipitation generally decreases with decrease in elevation until a minimum is reached in the vicinity of Lake Berryessa. The magnitude of precipitation and resultant run-off varies over a wide range throughout the area and erratically from year to year. However, there are numerous springs which maintain a limited year-round flow.

Putah Creek is classified as a perennial stream with intervening intermittant and ephemeral reaches. Records of monthly and seasonal flows in Putah Creek are reported by the U. S. Geological survey for the gaging station at Putah Creek near Guenoc. Records are available from the 
period 1930 to date and are summarized in Table 3.

TABLE 3

SURFACE WATER RECORDS

USGS GAGING STATION

PUTAH CREEK NEAR GUENOC

(Acre-Feet)

Oct. Nov. Dec. Jan. Feb. Mar. Apr. May June July Aug. Sept. Iotal

$\begin{array}{llllllllllllll}\text { Maximum } 20,250 & 31,710 & 103,500 & 140,700 & 117,000 & 81,520 & 53,920 & 12,740 & 4,200 & 1,250 & 612 & 451 & 327,600\end{array}$

Minimum

42 Year

Average

989

$17 \quad 80 \quad 144 \quad 1,000 \quad 2,590$

$\begin{array}{llllll}3,500 \quad 1.580 & 594 \quad 271 & 36\end{array}$

$8.9 \quad 5.2$

$225 \quad 152$

145,230

Dry Creek, tributary to Putah Creek, is classified as an intermittent stream; it flows during prolonged periods but not continuously. It drains an area of about 13 square miles on the east slope of the Mayacmas Mountains. Estimated average seasonal run-off from Dry Creek is about 21,000 acre feet, and varies seasonally from 4,000 AF (water year 1930 - 31) to 53,000 AF (water year 1937 - 38). Almost 98\% of the run-off occurs on the average during the seven-month period November to May.

St. Helena Creek, also a tributary to Putah Creek, is classified as an intermittent stream. The drainage area of the upper reaches of St. Helena Creek about 7.7 miles squared with an estimated mean annual run-off of 14,500 acre-feet (Bu11. No. 99, Department of Water Resources, 1962). 


\section{Environmental Consultants}

Water Qúality

No significant ground water quality problems have been reported for Colloyami Valley (Table 4).

TABLE 4

MINERAL ANALYSIS OF GROUHO MATER

COLLAYOMI YALLEY (8/05/74)

MINERAL CONSTITUENTS IN mgle

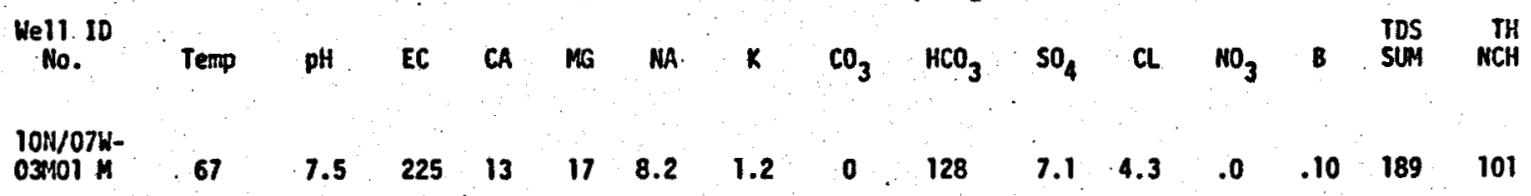

SOURCE: California Department of Water Resources, Bulletin No. 130-74, Hydrologic Data: 1974, Volume II: Northeastern Californis, December 1975.

High boron concentrations are reported in mineral analysis of ground water in Coyote Valley (Table 5).

TABLE $S$

MIMERAL ANALYSIS OF GROUNO WATER

COYOTE VALLEY (8/05/74)

MINERAL CONSTITUENTS IH MG/1

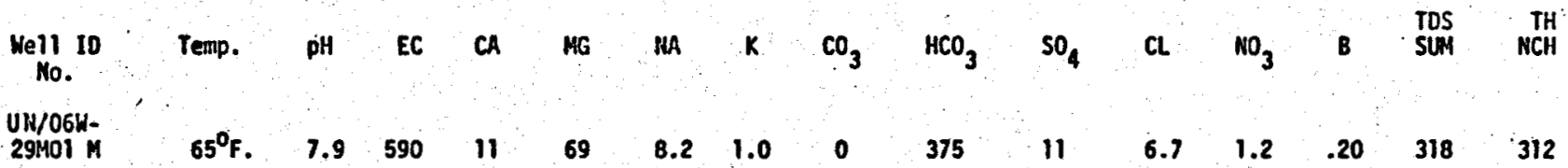

SOURCE: California Department of Mater Resources, Bulletin No. 130-74, Hydrologic Data: 1974, Volume II: Northeastern California, December 1975. 


\section{Environmental Consultants}

Surface waters in the Upper Putah Creek basin are predominantiy magnesium - bi-carbonate in cbaracter and are generally suitable for all beneficial uses (Table 6).

TABLE 6

MINERAL ANALYSIS

PUTAH CREEK 3 MILES

NORTHEAST OF MIODLETOWH

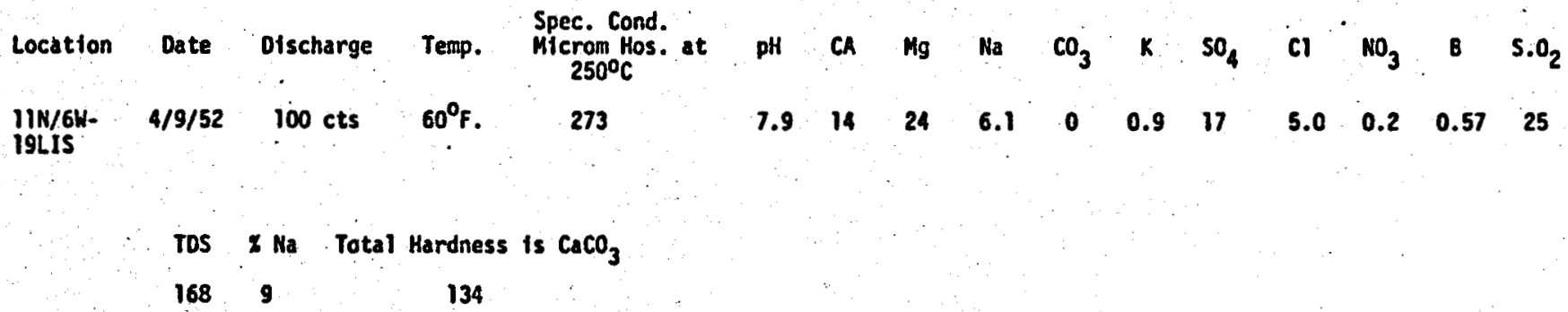

Source: Bulletin Mo. 58, Mortheastern Counties Investigation. Department of Water Resources, 1960.

The most general and widespread water quality problem of domestic users appears to be excessive hardness, principally due to calcium and magnesium. In some local areas, boron concentrations are high, making the water unsuitable for irrigation on all except the most tolerant of crops.

Several water quality analysis have been made of Dry Creek waters (Tables 7 and 8 ). The results of the analysis indicate that the mineral quality of the water is excellent and suitable for irrigation and domestic use. 
TABLE 7: Mineral analyses of surface mator suples in the Dry Croek draimge besin.

\begin{tabular}{|c|c|c|c|c|c|c|c|c|c|c|c|c|c|c|c|}
\hline \multirow[b]{2}{*}{$\begin{array}{l}\text { Damplo of } \\
\text { number sample }\end{array}$} & \multirow{2}{*}{$\begin{array}{l}\text { Specific } \\
\text { conduct- } \\
\text { ance } \\
\text { (miero- } \\
\text { mos at } \\
25^{\circ} \text { ) }\end{array}$} & \multirow[b]{2}{*}{ pH } & \multicolumn{5}{|c|}{ Mineral constituents, in } & \multicolumn{4}{|c|}{$\frac{\text { perts per mulition }}{\text { equivalents per mililion }}$} & \multicolumn{3}{|c|}{ perts per million } & \multirow[b]{2}{*}{$\begin{array}{l}\text { Total } \\
\text { hardness } \\
\left(\mathrm{CaCO}_{3}\right)\end{array}$} \\
\hline & & & $\begin{array}{l}\text { Cal- } \\
\text { ciua } \\
\text { (Ca) }\end{array}$ & $\begin{array}{l}\text { Magne- } \\
\text { s1us } \\
\left(r_{g}\right)\end{array}$ & $\begin{array}{l}\text { Sod- } \\
\text { lun } \\
(\mathrm{Na})\end{array}$ & $\begin{array}{l}\text { Potas- } \\
\text { giun } \\
(\mathrm{x})\end{array}$ & $\begin{array}{l}\text { carbon- } \\
\text { atso } \\
\left(\mathrm{CO}_{3}\right)\end{array}$ & $\begin{array}{l}\text { Blcar- } \\
\text { bonate } \\
\left.\text { ( } \mathrm{HCO}_{3}\right) \text {. }\end{array}$ & $\begin{array}{l}\text { Chlo- } \\
\text { ride } \\
\text { (c1) }\end{array}$ & 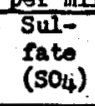 & $\begin{array}{l}\text { In- } \\
\text { trato } \\
\left(m_{3}\right)\end{array}$ & $\begin{array}{l}\text { Fiuo- } \\
\text { ride } \\
\text { (p) }\end{array}$ & $\begin{array}{l}\text { Boron } \\
\text { (B) }\end{array}$ & $\begin{array}{l}\text { sil1ca } \\
\left.(\mathrm{S10})_{2}\right)\end{array}$ & \\
\hline $11 / 22 / 63$ & 548 & 8.4 & $\frac{12}{0.60}$ & $\frac{64}{5.31}$ & $\frac{2.2}{0.14}$ & $\frac{0.3}{0.01}$ & $\frac{4}{0.13}$ & $\frac{276}{4.52}$ & $\frac{3.3}{0.09}$ & $\frac{58}{1.21}$ & $\frac{0.2}{0.00}$ & 0.10 & 0.12. & 18 & 296 \\
\hline $21 / 22 / 63$ & 598 & 8.5 & $\frac{11}{0.55}$ & $\frac{78}{6.42}$ & $\frac{2.8}{0.12}$ & $\frac{0.4}{0.01}$ & $\frac{12}{0.40}$ & $\frac{340}{5.57}$ & $\frac{11}{0.31}$ & $\frac{35}{0.73}$ & $\frac{0.2}{0.00}$ & 0.10 & 0.27 & 18 & 349 \\
\hline $3: 1 / 22 / 63$ & 354 & 8.3 & $\frac{9.9}{0.49}$ & $\frac{40}{3.31}$ & $\frac{3.6}{0.16}$ & $\frac{0.5}{0.01}$ & $\frac{0}{0.00}$ & $\frac{218}{3.57}$ & $\frac{2.4}{0.07}$ & $\frac{11}{0.23}$ & $\frac{0.4}{0.01}$ & 0.10 & 0.33 & 21 & 190. \\
\hline
\end{tabular}

TABLE 8: Chenieal analyses, in parts por nulion, watex rear $10 / 65$ to $9 / 66$.

\begin{tabular}{|c|c|c|c|c|c|c|c|c|c|c|c|c|c|c|c|c|c|c|c|c|c|}
\hline $\begin{array}{l}\text { Dete } \\
\text { of } \\
\text { oollection }\end{array}$ & $\begin{array}{c}\text { mean } \\
\text { discharge } \\
\text { (cfs) }\end{array}$ & $\begin{array}{l}\text { Spectfic } \\
\text { conduct- } \\
\text { anos } \\
\text { (nicro- } \\
\text { nos at } \\
25^{\circ} \text { c) }\end{array}$ & $\mathrm{pH}$ & $\begin{array}{l}\text { swica } \\
\left(\mathrm{S1O}_{2}\right)\end{array}$ & $\begin{array}{l}\text { Iron } \\
\text { (Fo) }\end{array}$ & $\begin{array}{l}\text { Cal- } \\
\text { clua } \\
\text { (Ca) }\end{array}$ & $\begin{array}{l}\text { nes- } \\
\text { siun } \\
(n s)\end{array}$ & $\begin{array}{l}\text { Sodiun } \\
\text { (Na) }\end{array}$ & $\begin{array}{l}\text { Po- } \\
\text { tas- } \\
\text { alua } \\
\text { (x) }\end{array}$ & $\begin{array}{l}\text { B1- } \\
\text { car- } \\
\text { bon- } \\
\text { ate } \\
\left(\mathrm{HCO}_{3}\right)\end{array}$ & $\begin{array}{l}\text { Car- } \\
\text { bon-s } \\
\text { ate } \\
\left(\mathrm{CO}_{3}\right)\end{array}$ & $\begin{array}{l}\text { Sulfato } \\
\left(\mathrm{SO}_{4}\right)\end{array}$ & $\begin{array}{l}\text { Chloride } \\
\text { (c1) }\end{array}$ & $\begin{array}{l}\text { Fuo } \\
\text { side } \\
\text { (F1) }\end{array}$ & $\begin{array}{l}\text { m1- } \\
\text { trate } \\
\left(\dot{m}_{3}\right)\end{array}$ & $\begin{array}{l}\text { Bo- } \\
\text { ron } \\
\text { (B) }\end{array}$ & $\begin{array}{l}\text { Dissolve } \\
\text { (calcul } \\
\text { Parts } \\
\text { per } \\
\text { mililion }\end{array}$ & $\begin{array}{l}\text { solids } \\
\text { tod) } \\
\text { Tons } \\
\text { por } \\
\text { acro- } \\
\text { loot } \\
\end{array}$ & $\begin{array}{l}\text { Hardn } \\
\text { as Ca } \\
\mathrm{Ca} \text {. } \\
\mathrm{Mg}\end{array}$ & $\begin{array}{l}\text { ness } \\
\mathrm{aCO}_{3} \\
\mathrm{Moh}- \\
\text { car- } \\
\text { bon- } \\
\text { ate }\end{array}$ & $\begin{array}{l}\text { So- } \\
\text { diun } \\
\text { ad- } \\
\text { sorp- } \\
\text { tion } \\
\text { ratlo }\end{array}$ \\
\hline $11 / 1 / 65$ & 0.1 & 536 & 8.6 & 20 & & 22 & 61 & 4.6 & 0.5 & 306 & 14 & 31 & 7.2 & & 0.7 & 0.1 & 312 & 0.42 & 304 & 30 & 0.1 \\
\hline $12 / 2 / 65$ & 8.8 & sei & 7.9 & 30 & & 34 & 51 & 16 & 2.0 & 348 & 0 & 16 & 15 & & 0.9 & .0 .4 & $342 *$ & 0.47 & 293 & 8 & 0.4 \\
\hline $2 / 1 / 66$ & 72 & 182 & 8.0 & 16 & & 4.8 & 20 & 1.6 & 0.6 & 109 & 0 & 5.0 & 0.9 & & 0.3 & 0.0 & $104 *$ & 0.14 & 94 & 5 & 0.1 \\
\hline$\cdot 3 / 1 / 66$ & 30 & 256 & 8.4 & 19 & & 10 & 27 & 2.9 & 0.3 & 151 & 6 & 6.0 & 2.3 & & 0.3 & 0.0 & 148 & 0.20 & 138 & 4 & 0.1 \\
\hline $4 / 1 / 66$ & 9.5 & $32 ?$ & 8.3 & 23 & & 7.2 & 39 & 3.3. & 0.3 & .201 & 3 & 10 & 1.6 & & 0.1 & .0 .0 & 187 & 0.25 & 180 & 10 & 0.1 \\
\hline $5 / 2 / 66$ & 5.3 & 363 & 8.4 & 21 & & 13 & 41 & 3.2 & 0.7 & 228 & 4 & 12 & 2.8 & & 0.5 & 0.0 & 210 & 0.29 & 203 & 9 & 0.1 \\
\hline $6 / 1 / 66$ & 1.9 & 417 & 8.2 & 22 & 0.00 & 12 & 48 & 4.2 & 0.6 & 268 & 0 & 13 & 3.5 & 0.0 & 1.6 & 0.1 & 237 & 0.32 & 229 & 9 & 0.1 \\
\hline
\end{tabular}

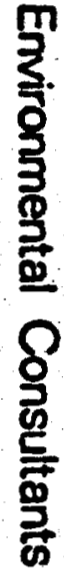




\section{Environmental Consultants}

Effects of Non electrical Development

The overall fresh water resource is very limited. So the use of non contaminated water for heat exchange purposes may be limited, unless a more stable water source can be located. The use of fresh water would lessen the impact of condensate, but place a strain on the area's water yield. The alternative is to reactivate the Dry Creek Dam project to store sufficient water to meet projected needs. 


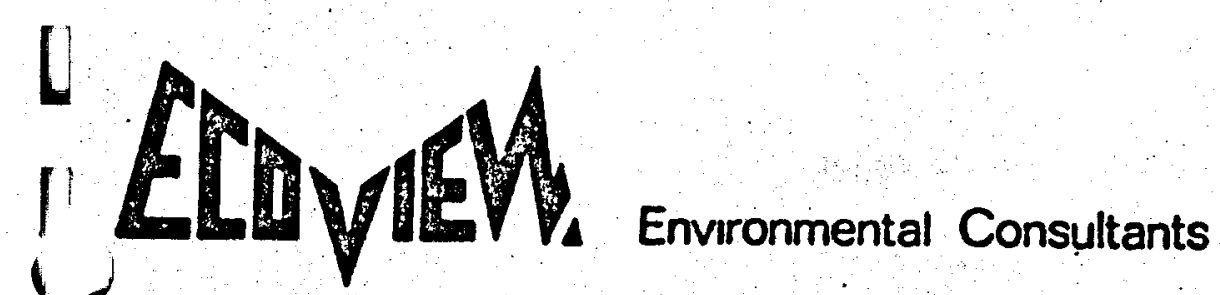

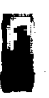

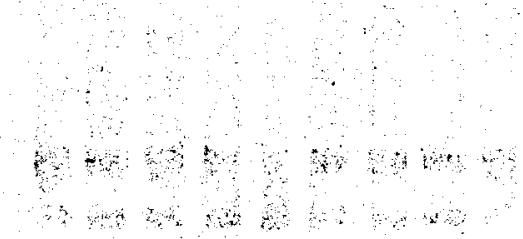

ENVIRONMENTAL REPORT

STUDY AREA IV

HIGH VALLEY GREEK - GLENBROOK AREA

Prepared under subcontract to Geonomics, Inc. as part of Phase Zero of the ERDA grant "Alternative Agribusiness and Industrial Uses for Exhaust Heat from Geothermal Waste Fluid, Lake County, Calif."

Submitted

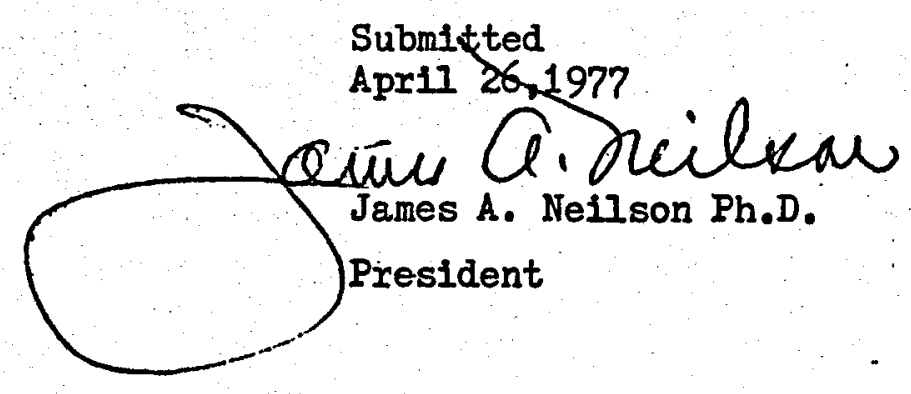




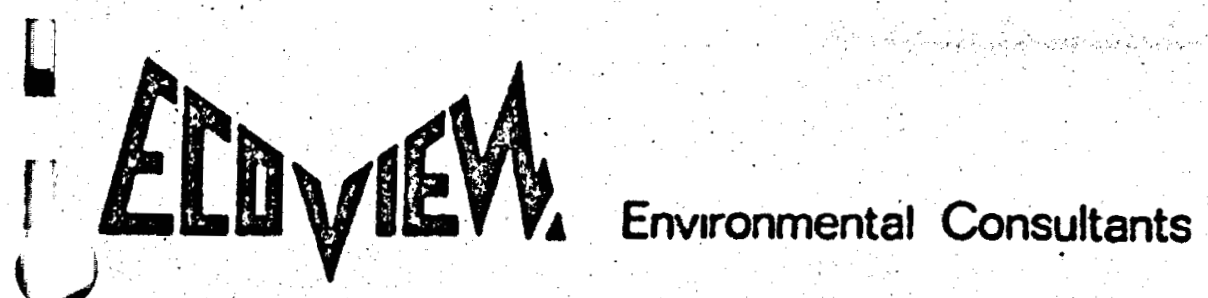

TABLE OF CONTENTS

\section{INTRODUCTION}

I. STUDY AREA IV GENERAL ASPECTS

Area Characteristics
Resource Status
Area Capability
.

II THE AIR RESOURCE - STATUS AND QUALITY

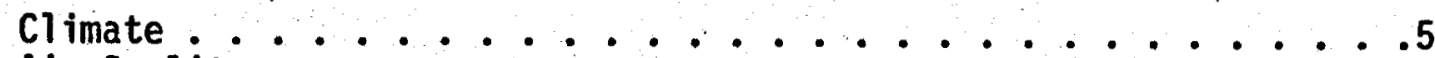

Air Quality ....................... 8

q Effects of Nonelectrical Development $\ldots \ldots \ldots$

III THE WATER RESOURCE - STATUS AND QUALITY

Underground Hydrology . . . . . . . . . . . . . 9

Surface Hydrology .................... 10

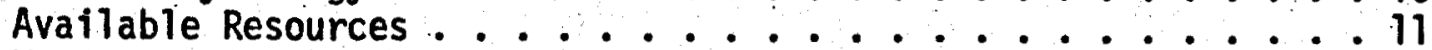

Water Quality . . . . . . . . . . . . . . 12

Effects of Nonelectrical Development . . . . . . . . 12

IV THE VEGETATION RESOURCE

Introduction .................... . . . . . .

Rare and Endangered Species . . . . . . 18

Effects of Nonelectrical Development ......... 18

V THE FAUNAL RESOURCE

Introduction ..................... 19

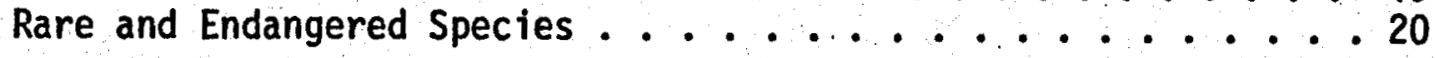




\section{Environmental Consultants}

\section{IIST OF FIGURES}

Frontispiece. Aerial view of the McCulloch leasehold.

Figure 1. Map delineating areas IV-A and IV-B.

Figure 2. Precipitation records for the general area.

Figure 3. Average monthly maximum and minimum temperatures.

Figure 4. Relationship of the precipitation and temperature regimes to plant growth requirements.

Figure 5. The area's drainage pattern and water quality sampling sites.

\section{LIST OF TABLES}

Table 1. Results of local hydrogen sulfide monitoring programs. 8

Table 2. Water quality characteristics for September, 1974. 13

Table 3. Water quality characteristics for December, 1974. : 14

Table 4. Water quality characteristics for April, 1975. 15

Table 5. Chemical analysis for Sample A, April, 1976. 16

Table 6. Chemical analysis for Sample B, April, 1976. 16 

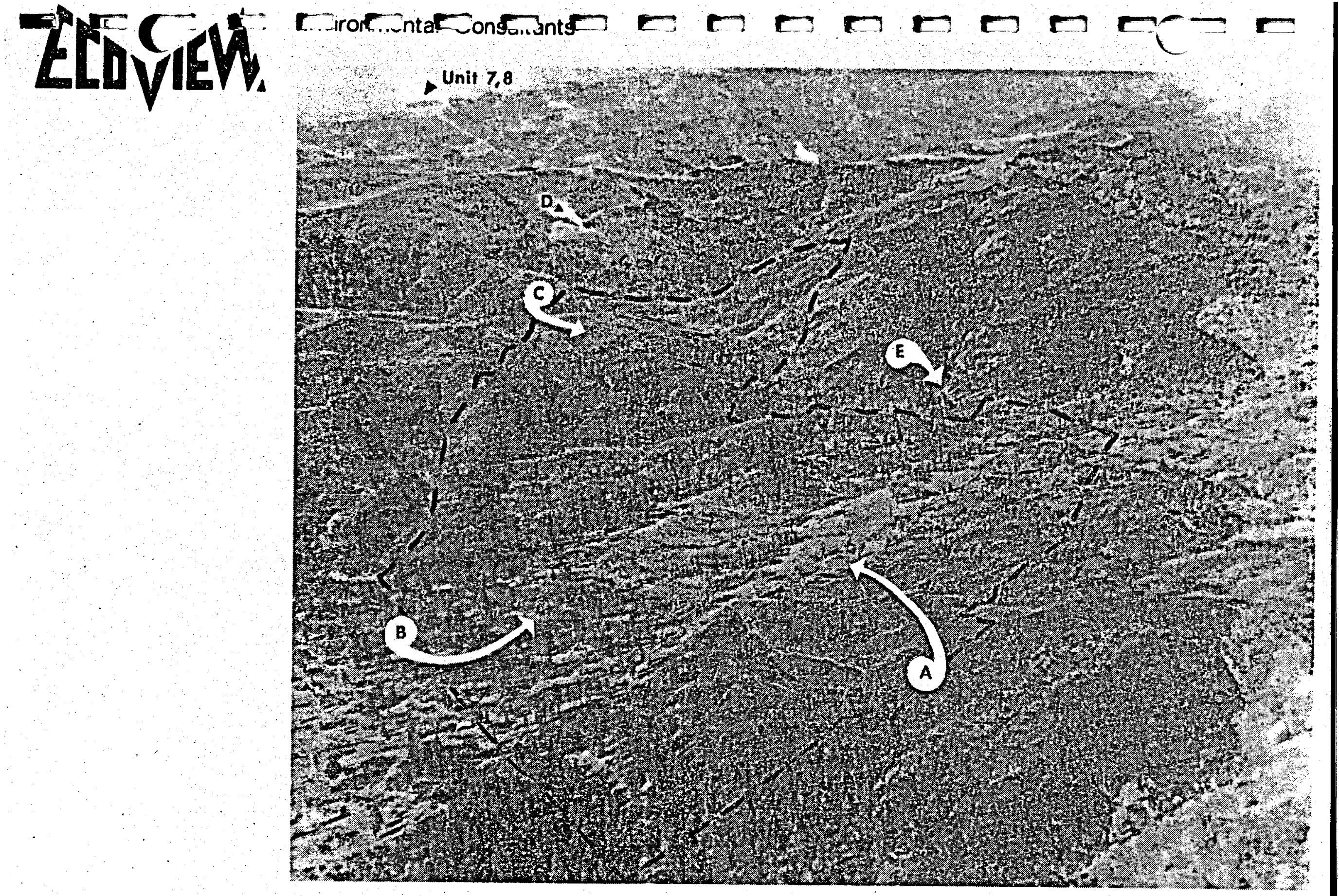

Frontispiece. An aerlal view of the Francisco leasehold looking west from $915 \mathrm{~m}$ ( $3000 \mathrm{ft}$ ). The dashed 1 ine indi-

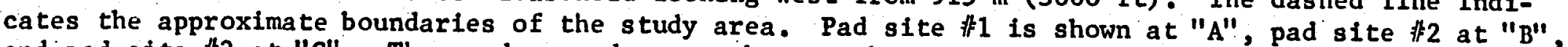
and pad site 非 at " $C$ ". The meadows and savannahs are shown in the lower left and middle foreground. Union O11 Company's 31 Horner we 11 is indicated at "D". PG\&E Units ${ }^{\prime \prime} 7$ and 非 are shown in the upper
left corner. The $L$ 'Esperance home is shown at "E". 
Environmental Consultants

INTRODUCTION

Study Area IV has been subdivided Into two general areass the High Valley Creek area, designated "IV-A", and the Glenbrook area, in the Kelsey Creek

- Drainage, designated "IV-B". Both are easily adaptable to potential development of nonelectrical uses.

ECOVIEW has completed several environmental studies within the High Valley Creek area, particularly the EIR for McCulloch Oil Company on the Francisco leasehold - the site of a good geothermal well.

The EIR for MCCulloch OIl's Cobb Valley leasehold deals with uplands east of Glenbrook. Little other environmental data is applicable to this project analysis. However, another. EIR is currently in progress that en-. compasses the greater part of the Glenbrook area valleys of "IV-B", but this will not be completed until June.

Environmental data included in this report are based unpon ECOVIEW'S own work in the areas; the SRI weather and air quality monitoring system data, and applicable reports, studies and data from government agencies, County of Lake, and geothermal developers in the area.

I. STUDY AFEA IV GENERAI ASPECTS

Area Characteristics

The study area's general terrain is a series of ridges and broad valleys varying in altitude between 2260 and 2800 f.t. Ridges west of Bottle Rock Road are composed largely of graywacke and serpentine, to the east of Lake County volcantcs. In general, interior hard chaparral, knobcone pine forest, and some yellow pine- or Douglas fir-black oak clothe the west ridges, while 
montane brushland and yellow pine-oak forest dominate the east ridges. Valley floors are open grasslands or savannahs containing wet meadow, California prairie, and introduced annual grasslands. Several flatland areas make the best areas for development. They occupy about 3 to 4 square miles, however only about $I$ square mile is readily adaptable to nonelectrical applications.

There are many landslide areas in the vicinity, thebest example being a large active landslide along. the. lower part of Sulphur Creek Road. Unstable soil is charactexistic of drainage and seep areas that form the wet meadows and the so called "bogs".

The settlement of Glenbrook is a remant of a larger town that once occupied this area in the late $1800^{\prime} s$. Both summer and permanent homes of larger land owners and retired persons are scattered throughout the area. The settlements of Cobb, Whispering Pines, and Hobergs lie 1 to 2 miles south and east of the Glenbrook area they are much more densely populated. The whole area is serviced by State Highway Route 175 and Bottle Rock Road.

Resource Stitus

Three exploratory wells have been developed in the general vicinity. The Phelps well, drilled by Union 0il Company in 1976, lies about $1 \frac{1}{2}$ miles south of the High Valley Creek area. It is a very good well, but has been capped off to await development of a large field on the west slope of Cobb. Mountain. The Horner Well, drilled by Unton 011 Company in 1974, is current 1y comected to the Unit IT Power plant supply system. The third well bin $\cdots$ longs to McCulloch Oil Company. Drilled in 1975, the well is located in the High Valley Creek Drainage (Study Area IV-A). McGulloch is currently drilling another well from the same pad. 
Wells of this area have the following general characteristics:

$$
\begin{aligned}
& \text { Steam temperature at well head _ } 142^{\circ} \mathrm{C}\left(287^{\circ} \mathrm{F}\right) \\
& \text { Condensate temperature } 270^{\circ} \mathrm{C}\left(80^{\circ} \mathrm{F}\right) \\
& \begin{array}{c}
\text { Condensate } \mathrm{pH}-4.25 \\
\text { Non-condensible/ condensable ratio is } 9.08 \mathrm{l} / \mathrm{kg} \text { at } 25^{\circ} \mathrm{C} \text { and } 1 \\
\text { atmosphere pressure. }
\end{array}
\end{aligned}
$$

Gas composition average of two samples is (in mol \%),

$$
\begin{aligned}
& \text { - } \mathrm{CO}_{2} \ldots . .78 .5 \mathrm{mg} / \mathrm{I} \\
& -\mathrm{N}_{2} \cdots 4 . ? \\
& \mathrm{H}_{2}^{2} \cdot . .8 .5 \\
& \mathrm{CH}_{4} \ldots 6.3 \\
& \mathrm{H}_{2 \mathrm{~S}} \ldots .2 .0
\end{aligned}
$$

Gondensate analysis average of 4 samples 1s:

$$
\begin{aligned}
& \mathrm{SO}_{4} \ldots 17.4 \mathrm{mg} / \mathrm{I} \\
& \mathrm{HCO}_{3}-\text { bicarb }-280 \\
& \mathrm{x} 3 \ldots 0.05 \\
& \mathrm{Na} \ldots 0.3 \\
& \text { F.... } 0.06 \\
& \text { B @ ... } 14.0 \\
& \text { Fe. . . } 0.57 \\
& \mathrm{Hg}: \ldots 0.0006 \\
& \mathrm{NH}_{3}-\mathrm{N} \because \ldots 63.0 \\
& \mathrm{H}_{2} \mathrm{~S} \ldots \ldots 360.0
\end{aligned}
$$

Total alkalintty ................ $230 \mathrm{mg} / \mathrm{l}$ Total dissolved solids at $180^{\circ} \mathrm{C}$.... 60 Turbidity unft .................... 36 pH............................. 6.1 Specific conductuctivity Micrombos $25^{\circ} \mathrm{C}$

\section{Area Capability}

The general configuration of usable sites in Study Area IV for nonelectrical uses is Iimited. However, several broad valleys present can be adapted (Frontispiece ). Each areas has certain problems which restrict extensive development, but will good planning and close geothermal resource development a significant integrated use system can be devised. 


\section{Environmental Consultants}

Essentially; the area is topographically divided into two parts: the High Valley Creek area and a tributary locally referred to as Cow Creek (IV-A on Figure 1), and the Glenbrook area (IV-B). Area " $A$ " has several distinct advantages that can be put to immediate use as far as this project is concerned, 1.e.1 1) Isolated from public view and from summer homes, 2) a proven Geothermal resource, 3) an owner and developer receptive to the idea of nonelectrical uses as an adjunct to electrical production, and 4) sufficient land area to establish an economical cascade or interdependent intergrated use system. It is also close to local markets that can be adapted to utilize the product.

Negative aspects include a restricted land area for large extensive operations, a narrow access road; and a slow main road to markets out of Lake County. The most critical problem is a local source of clean irrigation water uncontaminated by growth inhibiting salts. Some of the land area is restricted from use because in wet years it is a bog and the soil tends to flow under pressure. Nevertheless; both for short range and long range planning, the positive aspects of rea IV outweigh the negative aspects, assuming the operation is very carefully planned. As discussed in subsequent sections, no other adverse effects are noted.

Area IV-BI:" is a broad valley with considerable areas of low relief. At first glance, this area would seem to offer extensive possibilities; however, there are complicating features that may restrict

long sustained light farming and residential use. The main problems lie in land use conflictsi 1) the Carlos Cienaga Roncho bog orchid natural area. This area is registered with the natural areas coordinating council as a potential preserve, 2) the known population sites (including the type site) of the rare and endangered local endemic Hesperolinon bicarpelatum and other rare endangered species; 3) a long established summer camp for children, and 4) several historical and archaeogical sites.

As with 1te IV-A, wet meadow areas must be avoided because the soil, when wet, tends to flow if placed under pressure. While this can be overcome by 



\section{CDMPE Envronmental Consultants}

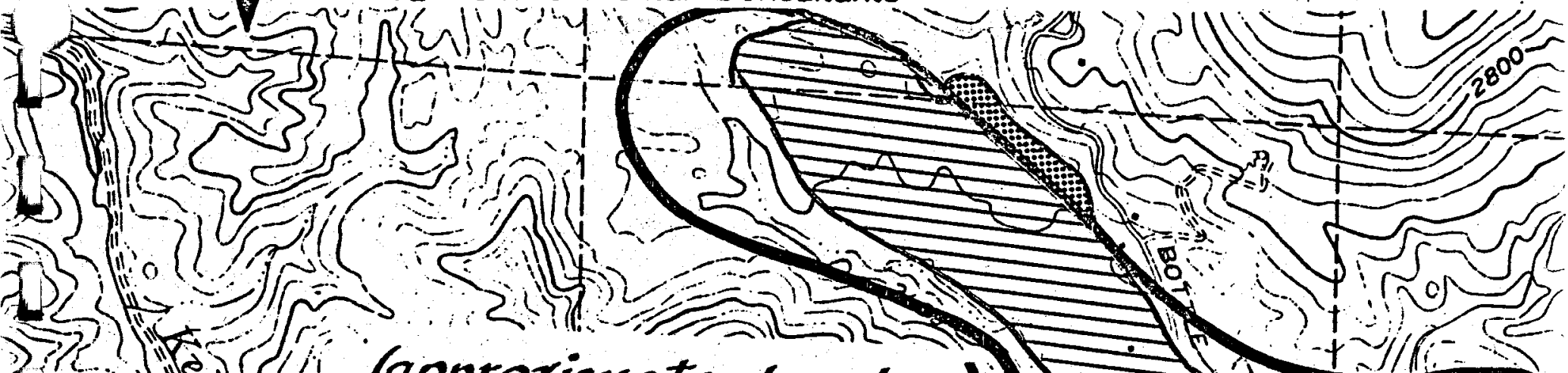

If) Natural

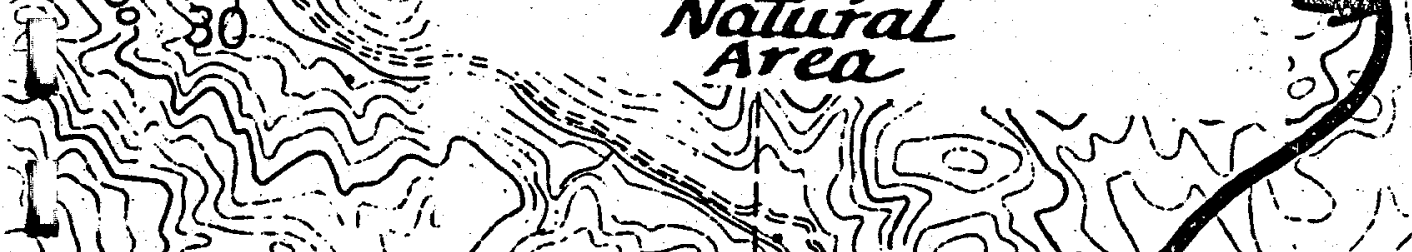

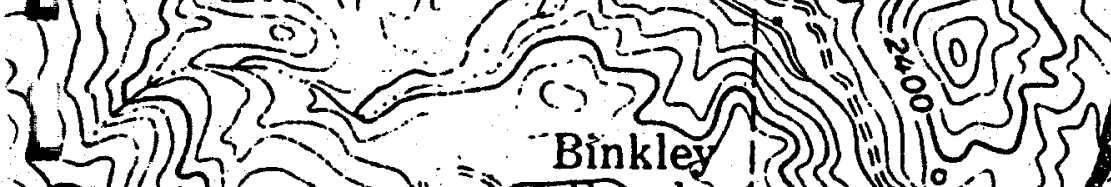
(1) (1) 
Environmental Consultants

engineering design, drainage, and compaction, the presence of the natural area and rare-endangered species preclude action, at least for the present. Also, the hydrology and water bearing capacity of the valley is unclear. No environmental report on the area has or will have developed sufficlent data to establish these factors. However, stream water quality is somewhat better known than that for Area IV-A. Even if we assume the foregoing factors can be avolded or overcome, no geothermal resource is currentily developed within the area. However, all the area is leased and preliminary steps are being taken by two developers to develop exploratory wells. Landowner acceptance of nonelectrical use concepts has not yet been investigated. Area IV-B as a whole has some advantages over Area IV-B in that access to Bottle Rock Road is proximal and an old airfield (Hobergs Airstrip) is within two miles. The latter needs to be rejuvenated if its use is contemplated for air delivery to distant markets.

II. THE AIR RESOURCE-STATUS AND QUALITY

Giimate

The climate of southern Lake County is governed by the orographs. effects of the North Coast Ranges which provide a barrier between the hot; dry air of the Sacramento Valley and the cooler, molst air of warm ocean water circulated by the Japanese Current along the California Coast. The area is characterized as winter-wet; summer-dry with relatively mild temperatures. Due to the complex terrain of the area, local climate is profoundly influenced by site topography.

Several stations have recorded weather conditions in the study area vicinity. The California Depaxtment of Water Resources maintains two stations: CobbVogel, located near the Cobb Post Office, and Cobb II-NW, located within section 5 of the study area. The Cobb-Vogel station has been operating since 1923 and provides the best long-term precipitation (FIgure II) and 
temperature data (Figure 3 ) available. The Cobb II-NW station has been in operation since 1961, taking only precipitation measurements (Figure 2). Precipitation data from the National Weather Bureau station at Hobergs (span of record is 43 years), a location topographically similar to the study area, is also provided in Figure II. Average seasonal rainfall for the area is approximately $66 \mathrm{in}$., most of whlch is concentrated during the 6 month winter period. Seasonal temperature range is moderate, with the average maximum temperature between $50^{\circ} \mathrm{F}$ and $87^{\circ} \mathrm{F}$ and the average minimum temperature between $30^{\circ} \mathrm{F}$ and $48^{\circ} \mathrm{F}$.

The regional winds affecting the area are of three basic types! 1) strong to moderate winds having a northerly component assoclated with the passage of cyclonic systems, 2) moderate to light winds having a southerly component associated with sea-breeze incursions, and 3) light to calm conditions associated with dominance of anti-cyclone systems. Local winds, being a
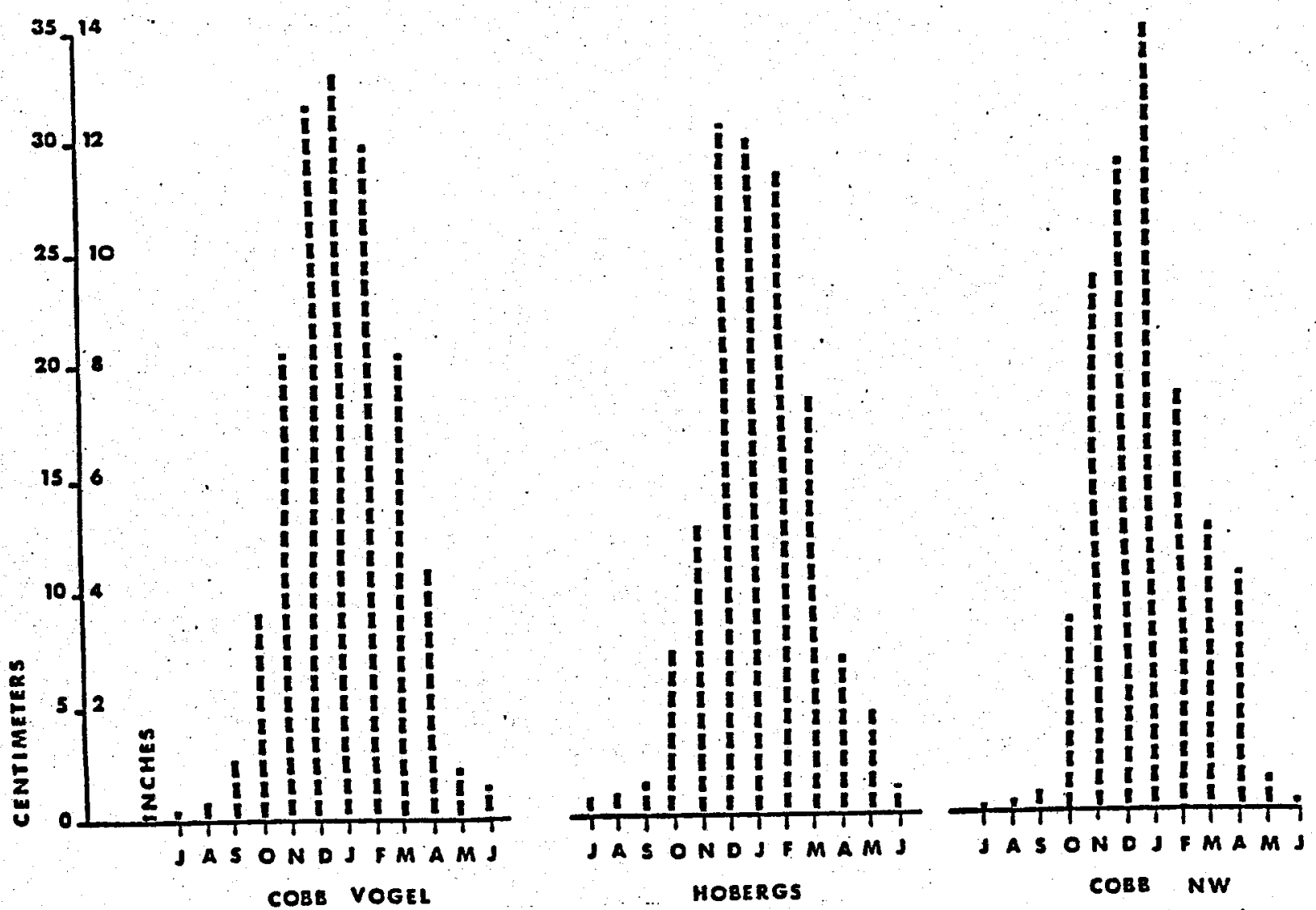

Figure 2. Proctpitation rocords for the general area of the leasehold. Cobb-Vogel station. 1s at 692 a (2250 ft) alt1tude and 13 a station of precipitation record since 1923 . Hobergs station is at $911 \mathrm{~m}(2960 \mathrm{ft})$ altitude and is a station of proetpltation record since 1930 . Cobb II 8.1 .18 at $708 \mathrm{~m}$ (2300 ft) ait1tude and is a station of precipltation and temperature record since 1963 . Average saowali is betiven 25 and $51 \mathrm{~cm}$ (10 and $20 \mathrm{in}$ ) annually at the leasehold. 


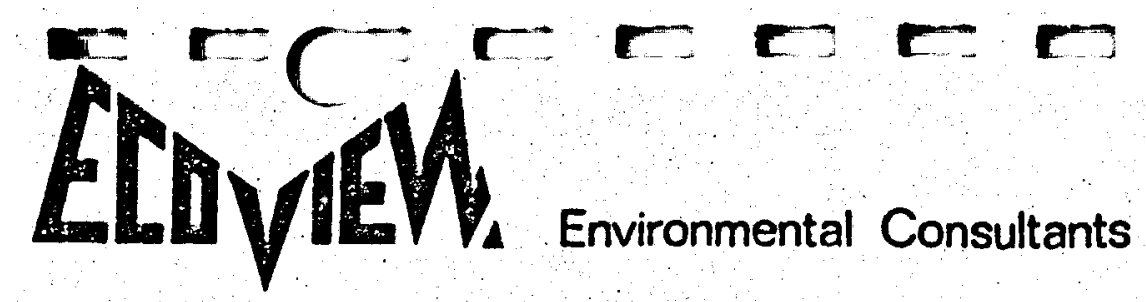

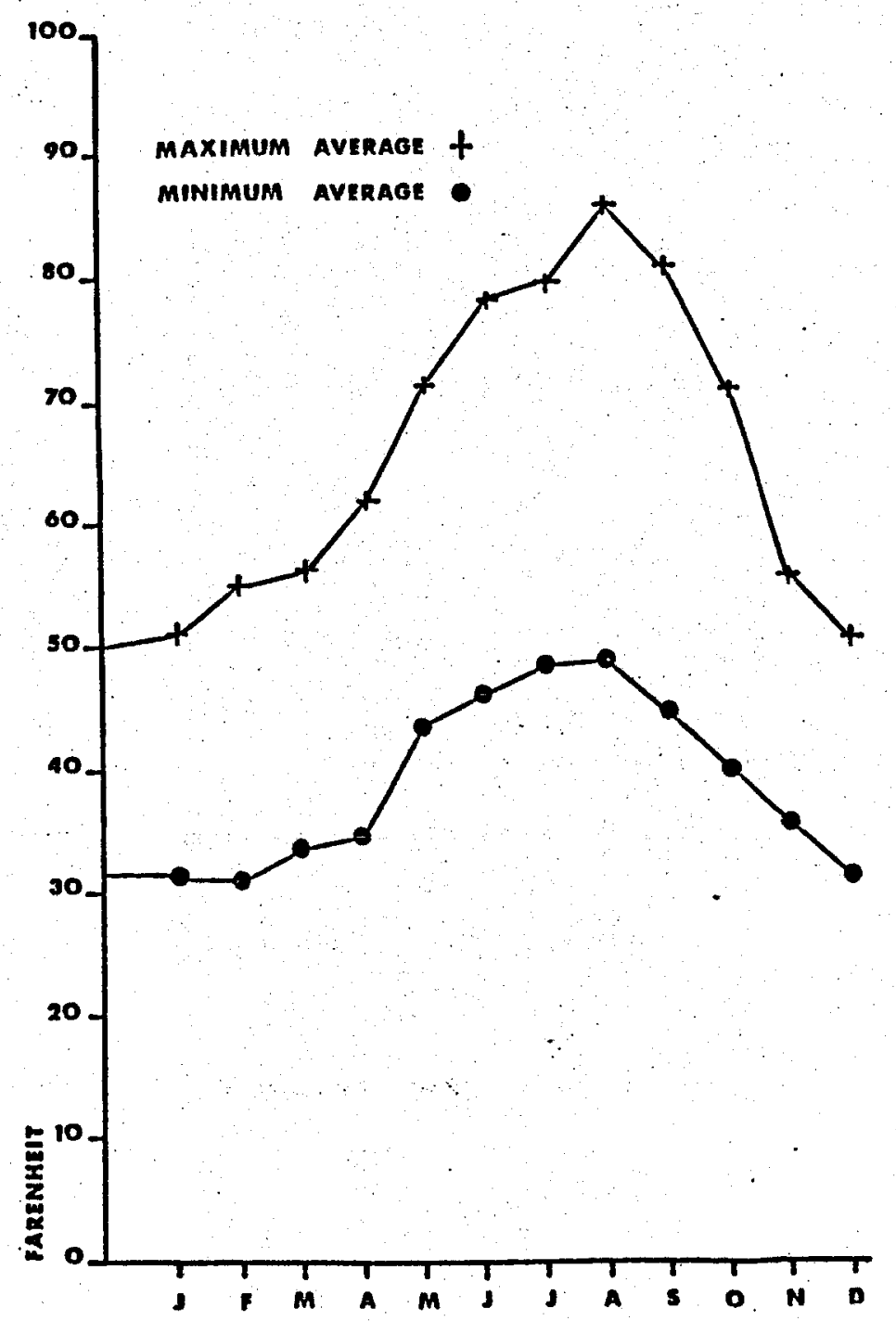

Figure 3.: Average monthly maximun and minimu temperatures for Gobb II H.W. Data courtesy of the Callfornia State Division of Hater Resources.

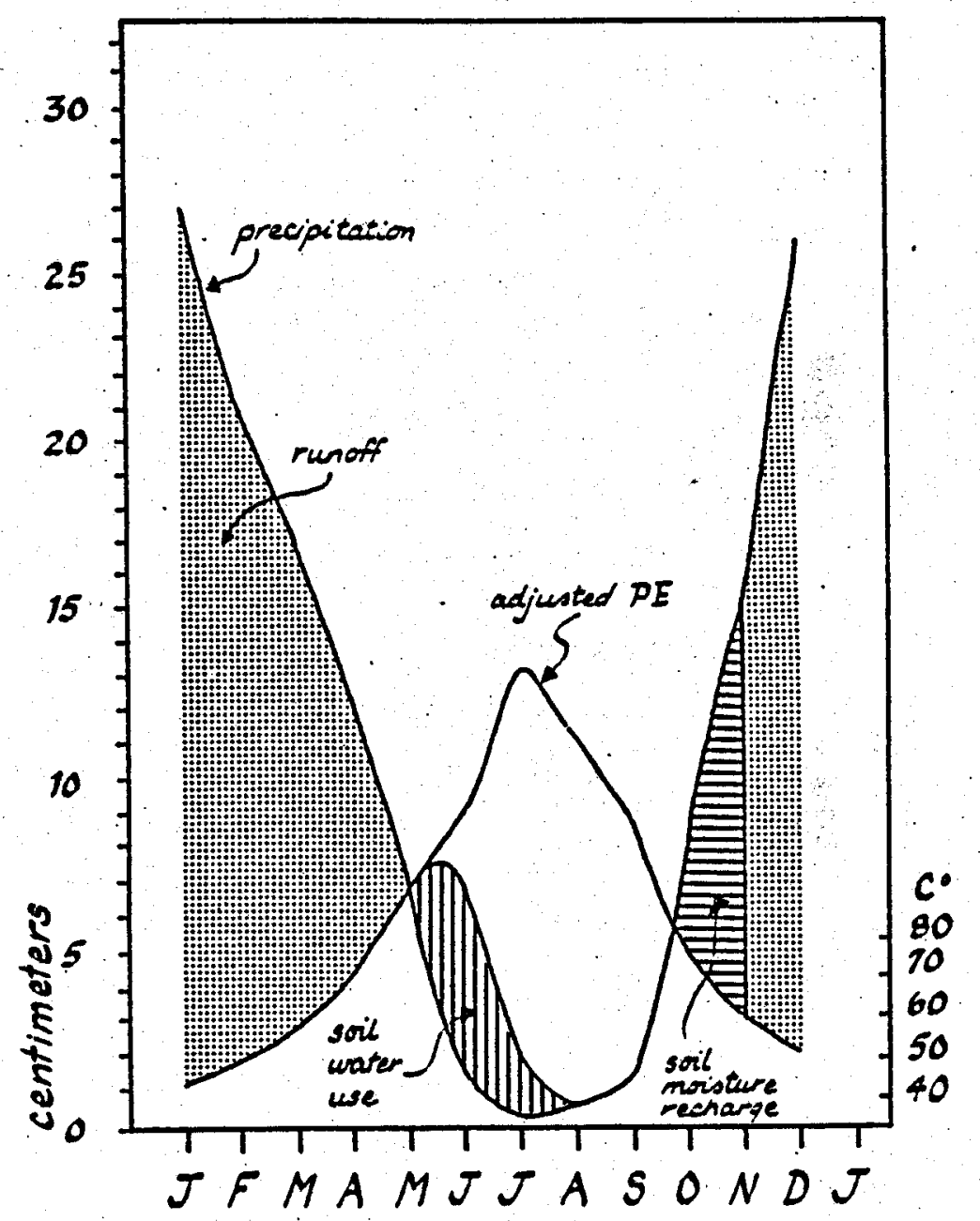

Figure 4, To relationship of precipitation regine and temperature regine to the growth requiriments of plants. As soil moisture dudndles, plants, requiring more vater than 1s available, stow drought symptons. As a rule, potential evapotranspiration drops to zero in January when temperatures are too low h in this part of california extensive evapozation. Crowch in this part or callsomia occurs during the narrow portod when war 


\section{Honvironmental Consultants}

product of these regional winds, are channeled and directed by terrain features. Superimposed on terrain modified regional patterns are up-valley winds during daylight hours, and down-valley drainage winds during night hours.

\section{Air Quality}

Characterization of the study area's air quality (with emphasis on hydrogen sulfide pollution) has been the objective of several monitoring programs conducted over the past two years. Hydrogen sulfide has been monitored at several sites in the vicinity by the Lake County Air Pollution Control District (ICAPCD) and the Stanford Research Institue (SRI). Results from these programs show that the California Ambient Air quality Standard for hydrogen sulfide is presently exceeded at times (Table 1). The hourly average $\mathrm{H}_{2} \mathrm{~S}$ concentration exceeded the standard from $2 \%$ to $24 \%$ of the days monitored. The air quality standard was exceeded most frequently to the

Table 1. Results of local hydrogen sulfide monitoring programs.

Monitoring Site Agency Period

Range of Hourly $\mathrm{H}_{2} \mathrm{~S}$ Concentrations Mêasured (ppb)
Percent of Days Which Average Exceeded $30 \mathrm{ppb}$

$\begin{array}{llllr}\text { Kahn Ranch } & \text { ICAPCD } & 8 / 1 / 75-9 / 12 / 75 & <10-41 & 23.6 \\ \text { Kahn Ranch } & \text { SRI } & 2 / 6 / 76-6 / 30 / 76 & & 10.6 \\ \text { PIne Summit } & \text { SRI } & 2 / 12 / 76-6 / 30 / 76 & & 2.6 \\ \text { Sawmill Flat } & \text { ICAPCD } & 9 / 19 / 75-10 / 19 / 75 & <10-40 & 13.3 \\ \text { Sawmill Flat } & \text { SRI } & 1 / 2 / 76-6 / 30 / 76 & & 1.6 \\ \text { Geyser Rock } & \text { ICAPCD } & 4 / 5 / 75-5 / 31 / 75 & <10-380 & 21.2 \\ \text { Geyser Rock } & \text { SRI } & 2 / 2 / 76-6 / 30 / 76 & & 36.9\end{array}$


southwest of the study area near the operating geothermal power plants in Sonoma County.

The California Air Resources Board monttoring program in the region indicates that, except for hydrogen sulfide, air quality within the air basin is excellent.

The Effects of Nonelectrical Development on Climate and Air Quality

The Impact of nonelectrical development on climate is expected to be negiible. The potential for impacts on air quality may be important. If we presume development solely for nonelectrical operations, several considerations should prevail.

- where steam is the resource, careful provisions need to be made to abate or contain gas and particulate emissions from escaping steam.

- where disagreeable odors originate from livestock, commerclal processes, or geothermal discharges; sources should be kept below tolerance levels and particularly not affect residential areas.

- all particulate emissions from any source should be contained within the use system and disposed of as appropriate for the nature of the material.

III. THE WATER RESOURCE - STATUS AND QUALITY

Underground Hydrology

The underground hydrology of any Study Area valley is nearly unknown. A few wells have been drilled for domestic purposes, but even those drilled In the center of side valleys are prone to go dry in years of below-normal rainfall. Much of the precipitation that falls on graywacke and serpentine 


\section{Environmental Consultants}

soils runs off almost immediately. Since for the most part soils are not well-developed, relatively little underground water is availa .

perhaps along Kelsey and Alder Creeks that tend to have water flowing much of the year. However, appropriating such water in quantity may significantly alter the broad valleys' water tables to negatively affect their ecology. Attempts were made by ECOVIEW to evaluate the morphology and water bearing capacity of several of these valleys when EIR's were negotiated, but funds were not forthcoming.

\section{Surface Hydrology}

Runoff within the study area flows almost entirely into High Valley Creek. The only exception being the south flank of the ridge near the northwest corner of Section 5; which drains into Alder Creek. Figure 5 shows the nature configuration of the drainage for area IV-A and IV-B.

High Valley Creek, originating in the Mayacmas Mountains, is about 6 mi long. In its upper reaches, flow is intermittent. Near its confluence with Kelsey Creeks; stream flow measurements range between 1.17 and $12.1 \mathrm{cu}$. $\mathrm{ft} / \mathrm{sec}$. Alder Creek, about $4 \mathrm{mi}$ long, also originates in the Mayacmas Mountains. Stream flow measured near its confluence with Kelsey Creeks aranges from 2.0 to $23.0 \mathrm{cfs}$. Numerous short, steep gradient, ephemeral streams drain the study area from headwaters situated along the surrounding ridge system. All larger creeks show rapid scouring activity apparently from recent large scale geologic movement.

Seep areas and wet meadows are subject to drying by late summer in most years and by early summer in years of low rainfall. It should be noted that these seeps and wet meadows occupy axeas of high ground in the flats and are usually next of high ajacent ridges. 


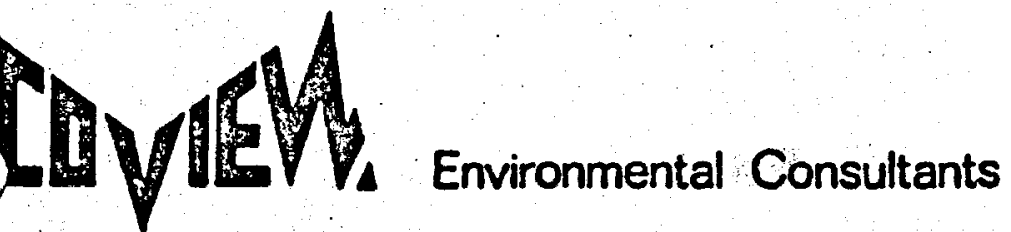

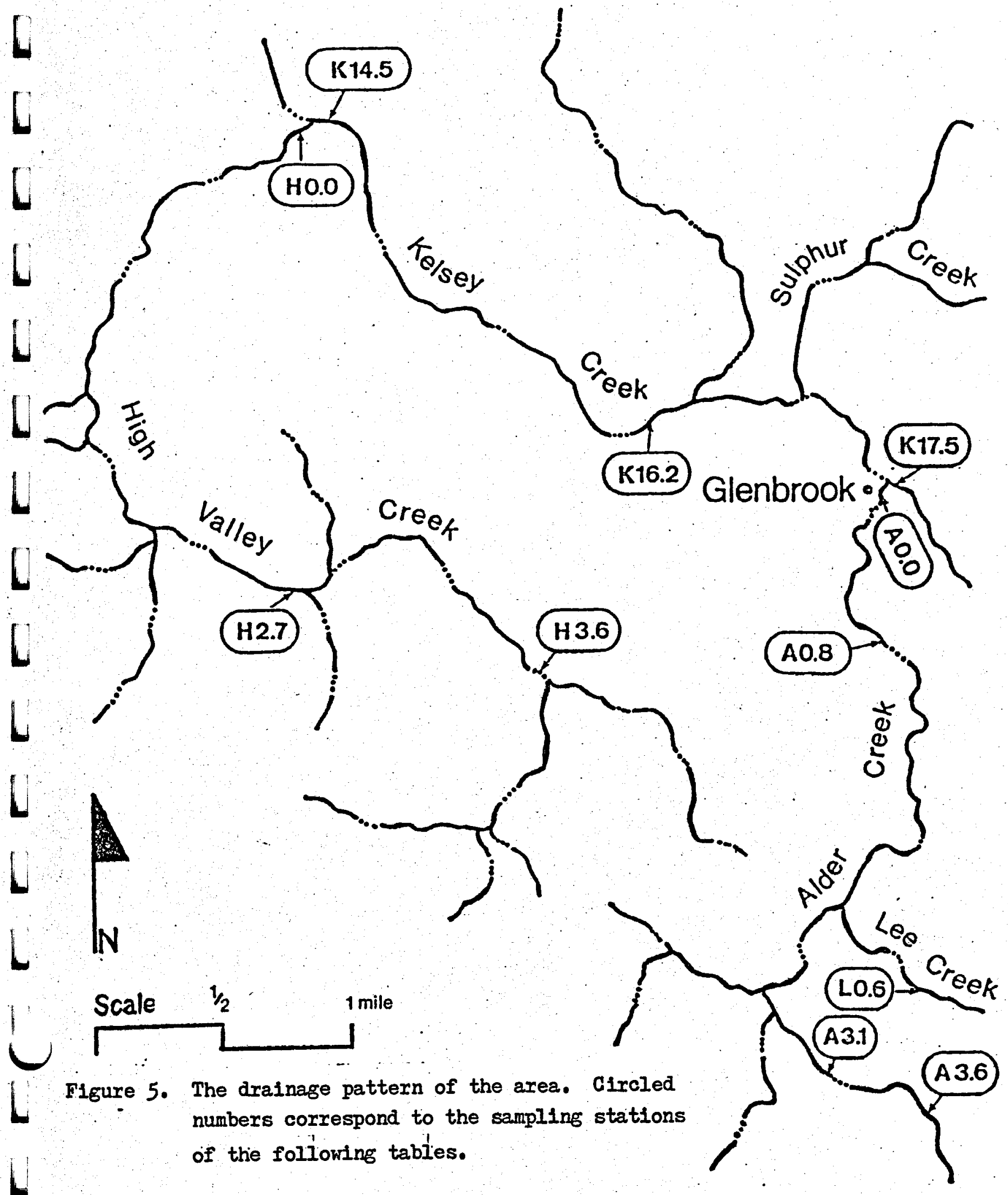




\section{Water Resources}

Supplies of high quality water may well be a concern for extensive development of some nonelectrical high water use applications. In Area IV-A small wells could be developed near High Valley Creek (see Water Quality, however). The configuration of the drainage of Upper Cow Creek is well adapted to water storage; but total drainage area for significant impoundment is relatively limited. It may; however, provide a supplemental source of usable water. Water could be supplied from the Cobb Valley Water District; however, this supply too, may be relatively Iimited. The best source is geothermal water itself if its quality is suitable.

\section{Water Quality}

Water quality characteristics of High Valley, Kelsey, and Alder Creeks were sampled intermittently over a two year period by Parametrix, Inc. and McCulloch 011 Corporation. The results of the monitoring indicate that both High Valley and Alder Creeks are cool, well aereated, and low in suspended and dissolved solids (see Tables 2-6). All High Valley Creek samples show the boron concentration to exceed the recommended limit for irrigation water.

\section{The Effects of Nonelectrical Development on Water Quality}

When one observes the Impacts of promiscucus discharges of geothermal waters in the Calistoga area, the importance of careful control cannot be overestimated. The followlng concerns should pertains

- provisions should be made to reinject or otherwise dispose of condensate or hot waters without pollution of surface waters or underground water supplies unless discharge water can be shown to be no less concentrated in salts of the same species than natiurally occurring water.

- Waste water discharges from nonelectrical enterprizes should be carefully controlled so that they will not create eutrophic or inhibitory effects on natural waters. 
Table 2. Water quality characteristics from the first sampling effort (Septmeber, 1974).

$$
\text { Unlts K K 11.5 K } 16.2 \times 17.5 \text { H } 0.0 \text { H } 2.7 \text { A } 0.0 \text { A } 0.8 \text { A } 3.1 \text { A } 3.6 \quad 10.6
$$

Date

Time

\begin{tabular}{ccccccccccc}
$\ldots$ & $9 / 10$ & $9 / 12$ & $9 / 12$ & $9 / 11$ & $9 / 14$ & $9 / 12$ & $9 / 14$ & $9 / 16$ & $9 / 16$ & $9 / 16$ \\
$\ldots$ & 1145 & 1105 & 1215 & 1120 & 1300 & 1345 & 1450 & 1030 & 1215 & 0910 \\
\hline
\end{tabular}

Air Temp.

\begin{tabular}{lllllllllll}
${ }_{\mathrm{C}} \mathrm{C}$ & 24.0 & 23.0 & 26.8 & 23.8 & 24.2 & 28.8 & 31.0 & 19.6 & 24.2 & 15.0 \\
\hline $0_{\mathrm{C}}$ & 18.8 & 16.4 & 15.6 & 19.8 & 14.4 & 20.8 & 18.9 & 11.6 & 11.1 & 12.1 \\
\hline
\end{tabular}

Water Temp.

Stream Flow

\begin{tabular}{|c|c|c|c|c|c|c|c|c|c|c|}
\hline cfs & 9.24 & $\therefore$ & - & 1.17 & $=$ & 1.96 & $\ddot{-}$ & $\cdots$ & $\ldots$ & 0.1 \\
\hline $\begin{array}{l}\text { MPUI } \\
100 \mathrm{il}^{2}\end{array}$ & 29 & 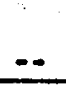 & 53 & 15 & - & 93 & 43 & 75 & - & 15 \\
\hline JTU & 1 & 3.0 & 5.0 & 1 & 1 & 2.0 & 1 & 1 & $i$ & 1 \\
\hline
\end{tabular}

Turbidity

APHA $5 \quad 5^{\circ} 10$

Color

D. 0 .

$\overline{\mathrm{p}} \mathrm{H}$

Alkalinity

$\mathrm{H}_{2} \mathrm{~S}$

Sulfates

Nitrite-N

mglliter

8.21

$9.17 \quad 8.87$

$5 \quad 5$

5

7.43

8.20

8.04

$5 \quad 5 \quad 5$

--

7.50

$7.19 \quad 7.31$

$7.70 \quad 7.80$

$8.04 \quad 8.63$

9.29

$9.04 \quad 8.57$

mariser

mglliter 50.5

47.0

$45.0 \quad 153.6 \quad 155.0$

7.90

6.90

6.80

$6.90 \quad 7.09^{\circ}$

mg/licer 0.

mg/liter $\quad 3.0$

$0.1: 0.1$

$0.1 \quad 0.1$

25.7

24.7

18.2

$16.8 \quad 27.7$

NItrate $-N$

Ammonia-N

OII

Cyanide

Settleable

Solids

Chromium

Copper

Silver

Zine

Cadmium

Mercury

Boron

Tarbon Organ.

mg/liter $(0.005)(0.003)$

2.0

$3.0 \quad 2.0$

0.1

0.1

0.1

$0.1 \quad 0.1$

-

$\begin{array}{llll}\text { mg/liter } & 0.35 & 0.40 & 0.35\end{array}$

mg/liter 0.13

$0.12 \quad 0.10$

$(0.002)(0.003)$

$\frac{3.0}{0.012}$

3.0

2.0

$(0.004) \quad(0.003)$

$1.0 \quad 1.0$
$0.01-0.01$

$0.005)$

$0.35 \quad 0.40$

0.3

0.4

$0.14 \quad 0.23 \quad 0.1$

0.2

mglliter $10 \quad 10 \quad 10$

mg/liter $0.05 \quad 0.05$

$10 \quad 10 \quad 10$

(2.0) $\quad 10$

$0.05 \quad 0.0$

0.05

0.05

$1.0 \quad 1.0$

1.0

1.0

0.30

0.30

0.01

mglliter $1.0,1.0 \quad 1.0: 1.0$

$\begin{array}{llllll}\text { ugllicer } & 0.2 & 0.9 & 0.2 & 0.2 & 0\end{array}$

uglliter $0.3 \quad 0.3$

0.3

$0.3: 0.3$

0.2

0.2

0.1

$0.1 \quad 0.1$

ugliter $0.13 \quad 0.03$

\begin{tabular}{|c|c|c|c|c|c|c|c|c|c|c|}
\hline uglliter & 64 & 16 & 51 & 16 & 5 & 25 & 30 & 15 & 5 & 16 \\
\hline ug/liter & 0.02 & 0.02 & 0.07 & 0.02 & 0.02 & 0.02 & 0.02 & 0.02 & 0.07 & 0.31 \\
\hline ugliliter & 0.64 & 0.46 & 2.17 & 4.61 & 0.75 & 2.74 & 0.32 & 0.72 & 0.32 & 0.56 \\
\hline malliter & 0.8 & 2.0 & 2.0 & 5.0 & 5.0 & 2.0 & 3.0 & 0.3 & 0.8 & 0.4 \\
\hline mg/liter & 8 & 5 & 5 & 7 & 7 & 2 & 6 & 2 & 2 & 3 \\
\hline ug/liter & 0.7 & 5.2 & 2.8 & 0.2 & 6.6 & 1.4 & 6.6 & 3.1 & 0.7 & 7.6 \\
\hline mg/liter & 0.4 & $0.4^{\circ}$ & 0.4 & 0.4 & 0.4 & 0.4 & 0.4 & 0.4 & 0.4 & 0.4 \\
\hline ug/liter & 0.4 & 0.4 & 0.4 & 0.4 & 0.4 & 0.4 & 0.4 & 0.4 & 0.4 & 0.4 \\
\hline ug/licer & 0.4 & 0.4 & 0.4 & 0.4 & 0.4 & 0.4 & 0.4 & 0.4 & 0.4 & 0.4 \\
\hline malliter & 0.1 & 0.1 & 0.1 & 0.1 & 0.1 & 0.1 & 0.1 & 0.1 & 0.1 & 0.1 \\
\hline $\mathrm{mg} / 1 / \mathrm{cer}$ & 0.1 & 0.1 & 0.1 & 0.1 & 0.1 & 0.1 & 0.1 & 0.1 & 0.1 & 0.1 \\
\hline
\end{tabular}

0.03

0.03

$\therefore 0.3$

0.3

$10 \quad 10$

$10 \quad 10$

Lead

Nitrogen,

Total

Arsenic

Selentum

Chlorine,

Crreérine.

Total

upstream area was observed to have been recently graded - possible oil from machines grading.

Sourcel Parametrix, Inc. 


\section{EEOy}

Table 3. Water quality characteristics from the effort of December 1974.

\begin{tabular}{|c|c|c|c|c|c|c|c|c|c|c|c|c|}
\hline & Units & $\mathrm{K} 74.5$ & $\mathrm{~K} 16.2$ & $\mathrm{~K} 77.5$ & $\mathrm{HO} . \mathrm{O}$ & H2.7 & H3.6 & $A 0.0$ & $A 0.8$ & A3.1 & A3.6 & 10,6 \\
\hline Date & $-\infty$ & $12 / 12$ & $12 / 12$ & $12 / 15$ & $12 / 12$ & $12 / 14$ & $12 / 14$ & $12 / 15$ & $12 / 14$ & $12 / 13$ & $12 / 13$ & $12 / 13$ \\
\hline Time & $-\cdots$ & 1030 & 1300 & 0830 & 1000 & 0915 & 1030 & 1000 & 1130 & 0930 & 0845 & 1045 \\
\hline Air Temp. & ${ }^{\circ} \mathrm{C}$ & 11.1 & 11.1 & 9.4 & 11.1 & 8.3 & 8.9 & 13.9 & 10.6 & 6.1 & 5.0 & 4.9 \\
\hline Water Temp. & ${ }^{\circ} \mathrm{C}$ & 9.1 & 10.1 & 8.7 & 8.4 & 9.4 & 8.6 & 8.3 & 7.4 & 7.0 & 7.9 & 6.0 \\
\hline Stream Flow & cfs & 8.76 & $-\infty$ & $(6.75)$ & 2.88 & $-\infty$ & $\therefore-$ & 2.64 & $-\cdots$ & 2.00 & $-\infty$ & .05 \\
\hline Total Coliforms & $100 \mathrm{mi}^{2}$ & 75 & $-\infty$ & 160 & 15 & -- & $>1100$ & $>1100$ & 53 & 44 & $-\infty$ & 36 \\
\hline Turbidity & JTU & 8 & 5 & 5 & 5 & 0 & 0 & 0 & 0 & 22 & 0 & 0 \\
\hline Apparent Color & APHA & 17 & 10 & 20 & 15 & $<5$ & $<5$ & 10 & $<5$ & 50 & $<5$ & $<5$ \\
\hline Dissolved Oxygen & mg/1iter & 10.24 & 9.80 & 10.33 & 10.96 & 8.61 & 9.39 & 10.57 & 10.90 & 1053 & 1037 & 10.46 \\
\hline $\mathrm{pH}$ & $-\infty$ & 6.80 & 6.80 & 6.10 & 7.70 & 6.70 & 6.50 & 6.45 & 6.30 & 6.30 & 6.30 & 6.20 \\
\hline Alkalinity & $\mathrm{mg} /$ liter & 60.0 & 55.5 & 41.3 & 140.6 & 123.0 & 93.2 & 33.2 & 32.9 & 19.4 & 17.4 & 27.0 \\
\hline Sulfates & mg/1iter & 7.4 & 7.0 & 2.2 & 9.5 & 3.7 & 8.6 & 4.1 & 4.4 & 7.1 & 1.0 & 1.0 \\
\hline Nitrite - N & mg/liter & $<0.01$ & $<0.01$ & $<0.01$ & $<0.01$ & $<0.01$ & $<0.01$ & $<0.01$ & $<0.01$ & $<0.01$ & $<0.01$ & $<0.01$ \\
\hline Nitrate $-N^{*}$ & $\mathrm{mg} /$ ii.ter & $-\infty$ & $-\infty$ & $<0.1$ & -- & .27 & $<0.1$ & $<0.1$ & $<0.1$ & .10 & $<0.1$ & $<0.1$ \\
\hline Nitrate - N** & mg/liter & .12 & .12 & .10 & $<0.1$ & .30 & $<0.1$ & $<0.1$ & .11 & .11 & $<0.1$ & .19 \\
\hline Ammonia - N & mg/liter & .28 & .21 & .12 & .33 & .26 & .25 & $<0.1$ & .13 & .18 & $<0.1$ & $<0.1$ \\
\hline Settleable Solids & $\mathrm{mg} /$ liter & $\angle 1.0$ & $<1.0$ & $<1.0$ & $<1.0$ & $<1,0$ & $<1.0$ & $<1.0$ & $<1.0$ & $<1.0$ & $<1.0$ & $<1.0$ \\
\hline Zinc & ug/11ter & $<0.6$ & 16 & $<0.6$ & $<0.6$ & $<0.6$ & $<0.6$ & $<0.6$. & $<0.6$ & $<0.6$ & 3 & $<0.6$ \\
\hline Mercury & ug/1iter & 0.08 & 0.47 & $<0.02$ & $<0.02$ & $<0.02$ & $<0.02$ & 0.02 & $<0.02$ & $<0.02$ & $<0.02$ & $<0.02$ \\
\hline Boron & mg/liter & 11 & 9 & 9 & 18 & 17 & 14 & 7 & 7 & 8 & 7 & 7 \\
\hline $\begin{array}{l}\text { Lead } \\
\text { * Nitrate analysis }\end{array}$ & $\begin{array}{l}\text { ug/11ter } \\
\text { using the }\end{array}$ & $\begin{array}{l}60.2 \\
\text { Brucine }\end{array}$ & $\begin{array}{l}<0.2 \\
\text { Method }\end{array}$ & $\begin{array}{l}<0.2 \\
\text { in a Gilf }\end{array}$ & $\begin{array}{l}<0.2 \\
\text { ford Spe }\end{array}$ & $\begin{array}{l}<0.2 \\
\text { ctrophot }\end{array}$ & $\begin{array}{l}<0.2 \\
\text { tometer. }\end{array}$ & $<0.2$ & $<0.2$ & $<0.2$ & 20 & $<0.2$ \\
\hline $\begin{array}{l}\text { * Nitrate analysis } \\
\text { as comparative an }\end{array}$ & $\begin{array}{l}\text { using aron } \\
\text { nd backup d } \\
\text { Tnn. }\end{array}$ & $\begin{array}{l}\text { matic ort } \\
\text { data for }\end{array}$ & $\begin{array}{l}\text { tho di } \\
\text { the a }\end{array}$ & $\begin{array}{l}\text { mine rea } \\
\text { ove, Nit }\end{array}$ & $\begin{array}{l}\text { sents / C } \\
\text { ate test }\end{array}$ & Sadmium $r$ & auction & met & In a Hach & Ch Co & eter to & serve \\
\hline
\end{tabular}




\section{ELyin. \\ Environmental Consultants}

Table 4. Water quality characteristics from the effort of April, 1975.

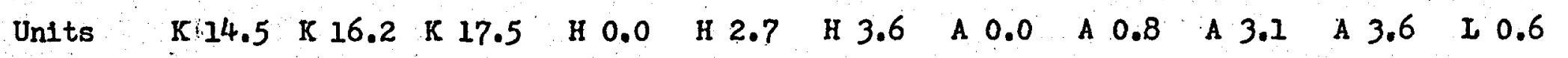

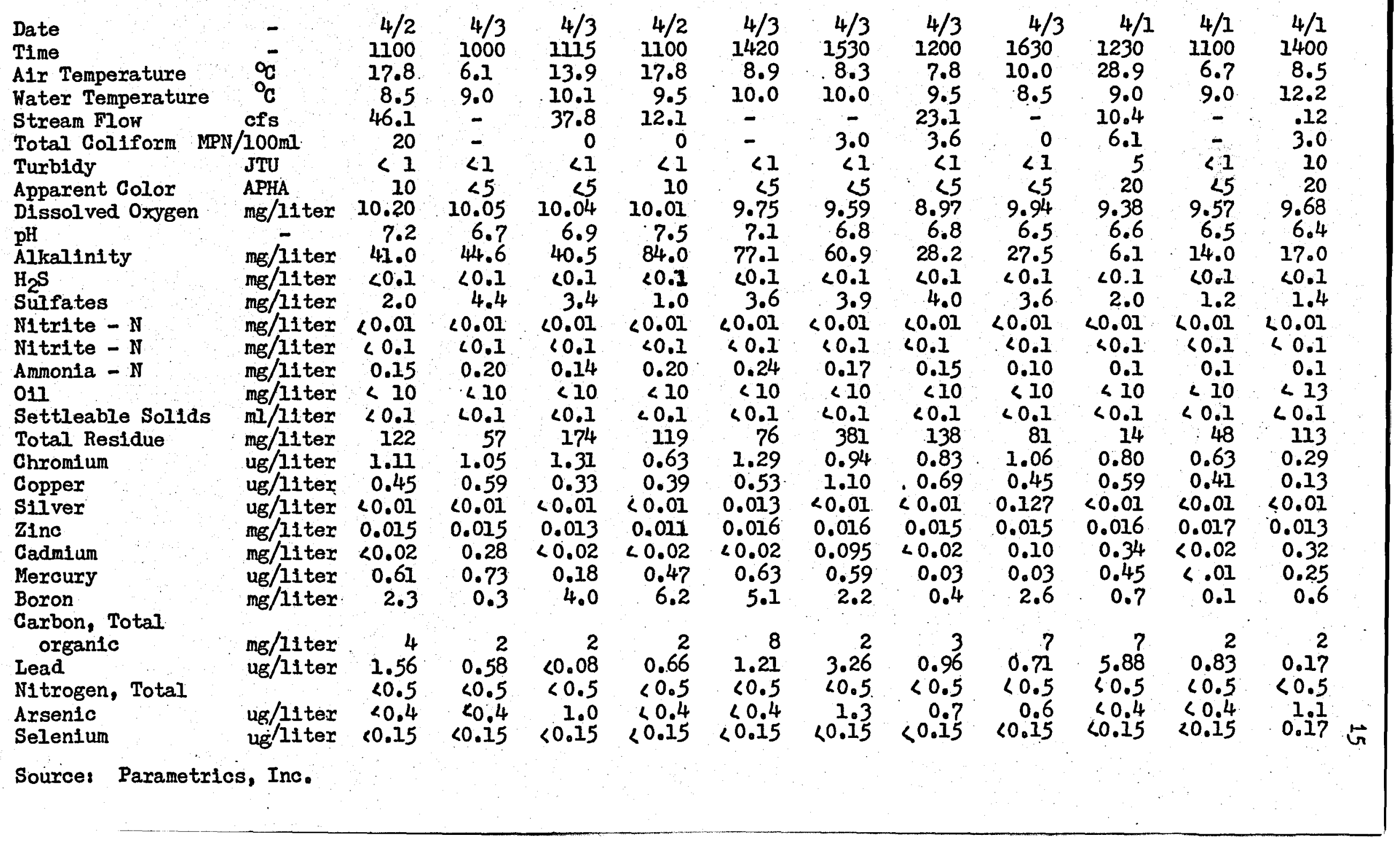


Envronmental Consultants

Table 5. Chemical analysis for Sample A on Kelsey Creek upstream of confluence with High Valley Creek. Sample was collected on April 4, 1976 by Brelje and Race Laboratorles.for McCulloch 011 Corp. The analysis number is 476-2293 and was run on April 29,1976.

\begin{tabular}{|c|c|c|c|c|c|}
\hline Major Anions & $\operatorname{mg} / 1$ & Determination & $\mathrm{mg} / \mathrm{l}$ & Determination & $m g / 1$ \\
\hline $\begin{array}{l}\mathrm{SO}_{4}^{-} \\
\mathrm{Cl}^{-} \\
\mathrm{HCO}_{3}^{-} \\
\mathrm{NO}_{3}^{-} \\
\mathrm{CO}_{3}^{-} \\
\mathrm{NH}_{4}^{-} \\
\mathrm{Major} \text { Cations }\end{array}$ & $\begin{array}{c}1.8 \\
2.6 \\
93 . \\
<0.1 \\
0 . \\
0.39\end{array}$ & $\begin{array}{l}\text { Total alkalinity } \\
\text { Calcium hardness } \\
\text { Magnesium hardness } \\
\text { Total hardness } \\
\text { Total dissolved sol. }\end{array}$ & $\begin{array}{l}76 . \\
28 . \\
42 . \\
70 . \\
110\end{array}$ & $\begin{array}{l}\text { B } \\
\text { AI } \\
\text { Mn } \\
\text { Fe } \\
\text { Grease \& } 011\end{array}$ & $\begin{array}{l}0.12 \\
0.6 \\
<0.05 \\
0.6 \\
2 .\end{array}$ \\
\hline $\begin{array}{l}\mathrm{Ca} \\
\mathrm{Mg} \\
\mathrm{Na}\end{array}$ & $\begin{array}{l}11 . \\
10 \\
5.5\end{array}$ & $\begin{array}{l}\text { Settleable solids } \\
\text { (ml/l/hr) } \\
\text { Turbidity (Tur. units) } \\
\text { (FTU ABS) }\end{array}$ & $\begin{array}{l}<.1 \\
8.6\end{array}$ & $\frac{\text { Heavy Metals }}{\text { Zn }}$ & $\begin{array}{l}<0.01 \\
<0.002\end{array}$ \\
\hline $\mathbf{K}$ & 1.5 & $\begin{array}{l}\mathrm{pH} \\
\mathrm{Sp} \text { cond. micromhos } \\
\text { (@ 250) }\end{array}$ & $\begin{array}{l}7.8 \\
160 .\end{array}$ & $\mathrm{Pb}$ & $<0.02$ \\
\hline
\end{tabular}

Table 6. Chemical analysis for Sample B on Kelsey Creek downstream of confluence with High Valley Creek. Analysis number 476-2294.

\begin{tabular}{|c|c|c|c|c|c|}
\hline Major Anions & $\mathrm{mg} / 1$ & Determination & $\mathrm{mg} / \mathrm{I}$ & Determination & $\mathrm{mg} / 1$ \\
\hline $\mathrm{SO}_{4}-$ & $<.5$ & & & & \\
\hline $\mathrm{CI}^{-}$ & 2.3 & Total alkalinity & 78. & B & 0.12 \\
\hline $\mathrm{HCO}_{3}-$ & 95. & Calcium haraness & 72. & AI & 0.54 \\
\hline $\mathrm{CO}_{3}^{-}$ & 0 & Magnesium hardness & 19. & Mn & $<0.05$ \\
\hline $\mathrm{NO}_{3}^{-}$ & $<0.1$ & Total hardness & 91. & $\mathrm{Fe}$ & $<0.02$ \\
\hline & 0.32 & $\begin{array}{l}\text { Settleable sollds } \\
(\mathrm{ml} / \mathrm{l} / \mathrm{hr})\end{array}$ & $<.1$ & Grease and 01 & 19.4 \\
\hline Major Cations & & Turbidity (Tur. units) & & Heavy Metals & \\
\hline $\mathrm{Ca}$ & 29 & (FTU ABS) & 6.8 & $\mathrm{Zn}$ & $<0.01$ \\
\hline $\mathrm{Mg}$ & 4.6 & $\mathrm{pH}$ & 8.0 & $\mathrm{Hg}$ & 0.022 \\
\hline $\mathrm{Na}$ & 5.1 & Sp. cond. micromhos & & $\mathrm{Pb}$ & $<0.02$ \\
\hline$K$ & 1.5 & & 170. & & \\
\hline
\end{tabular}




\section{Environmental Consultants}

- Modification of underground water supplies should be carefully monitored to Insure water quality is maintained.

\section{THE VEGETATION RESOURCE}

\section{Introduction}

Those parts of the study area selected as most adaptable to nonelectrical uses are the low broad valleys: The vegetation of such areas is predominantly grasslands and savannahs. There may be limited possibilities, especially for commercial or industrial processing, on ridge tops in Area IV-B assuming a resource is developed. In these areas, vegetation is largely chaparral to the west of Bottle Rock Road and chaparral brushland or pine-oak woodland east of the road.

These woodland and chaparral areas are still recovering from the severe wildfire that swept through the area in 1968. The fire load is again beginning to accumulate to the danger point, and any future fire that starts during the dry season can be expected to spread to devastating proportions rapidly if conditions are right. There appear to be too few fire breaks and no management practices to reduce fire load. Meadow communities are recovering very slowly from the effects of over-grazing in early days. Very little timber is of harvestable size, but most of the Laughlin, Josephine, Los Gatos, and some Yorkville loams have timber production potential. All these conditions point to a lack of proper management in the past; however, the area has considerable potential for vegetation management for better wildlife and water-: shed resources.

\section{Plant Communities}

The following descriptions are taken from ECOVIEW'S EIR and will describe in considerable detail typical plant communities forund in the area. Note, however, there are significant differences in species composition, especially in the shrub and herb layers, between the Franciscan greywacke and serpentine of $I V-A$ and the shists and volcanics of IV-B. The most striking 


\section{Environmental Consultants}

Rare and Endangered Species

Up to the time of this writing, no rare or endangered species were encountered, however, several habitats are present that could support several of the species known to be in the area, 1.e.. Erythroniun helenae, Fritilaria purdi1, Hesperolinon bicarpelatum and $H_{0}$ drymarioides lupinus sericatus has been observed to the north and to the south of the leasehold, but not on the leasehold.

The area is the type location for the bicarpelate flax (Hesperolinon bicarpelatum). The exact locational extent and strength of the populations has never been closely examined and only a few collections are on record in herbaria. This aspect may be examined later this spring by ECOVIEW personnel as part of a broader study of rare and endangered species in geothermal areas. The Effects of Nonelectrical Development on Vegetation

The most immediate effect of intense development of cascading geothermally related enterprises in Area IV-A is the removal of native vegetation. All the grasslands and savannahs are utilized by various kinds of wildlife (cf. fauna section). In order of Increasing importance; these can be ranked as follows: Introduced annual grassland, native mixed herb, valley oak savannah, and California prairie:

Much of the stand of the California prairie has already been removed as a result of current geothermal development. Even initial development of nonelectrical demonstration units will reduce native - herb and some ecotone vegetation bordering the wet meadow. Some of the big manzanita stand toward the upper part of the flat may be removed.

We recommend to others of the planning team restriction of development from the wet meadow and immediate stream side areas. - Only if absoIutely necessary should wet meadow be developed and then only with considerable engineering, careful planning, and restriction to the most adaptable 


\section{Environmental Consultants}

enterprises, 1.e. aquaculture.

Area IV-B is considerably more complex. Iand use decisions must be made regarding: 1 ) the potential for making the proposed natural area of Clenaga Rancho Bog Orchid Area into an officially registered natural preserve, reserve, or park; 2) the impact of any electrical or nonelectrical geothermal development on the summer camp atmosphere; and 3) the aesthetic impact of both electrical and nonelectrical enterprises on the retirement and summer homes in the valley. Anti-development decisions may severely restrict any further planning of nonelectrical uses for the area. If we assume that a moderate amount of development is socially and politically acceptable, there are still several areas with reasonable potential. The specific details of these areas (all grassland or wet meadow types simflar to those described for Area IV-A) will have to await: - completion of the EIR for the NCPA leasehold;

- a formal geomorphological examination of the valley sediments and their water bearing capacity; and

- the development of the resource.

If aesthetics is a problem; much of the area could be excluded on that basis alone. However, careful setting and construction could well remove much of the opposition to at least nonelectrical operation, particularly if the fesorrse is mostly hot water.

v. THE FAUNAL RESOURCE

Introduction

The occurence of faunal species is closely related to vegetation patterns. The degree to which vegetation and habitat is altered affects the modification and trends which determine changes in faunal species spectrum and relative numbers. In the case of some electrical supply flelds, the scattered developments appear to have little to moderate effect on existing populations of fauna. 


\section{Environmental Consultants}

However, the intense development considered in most cascade operations require a total removal of habitat involving 5 to 50 acres. The species involved will depend on the habitat selected for development.

\section{Rare and Endangered Species}

The peregrine falcon (Falco peregxinus), is the only endangered wildilfe species that is likely to occur in the vicinity of the proposed well sites which lie only $3.2 \mathrm{~km}(2 \mathrm{mi})$ northwest of the outer limits of the proposed Critical Habitat Zone surrounding the Cobb Mountain peregrine falcon eyrie site. Although there have been no known sightings of peregrines on the leasehold, it is very likely that they hunt over the area at least occasionally during the April-July period in those years when the eyrie is occupied. However, this is only one of many possible foraging sites available to peregrines in the Cobb Mountain region and there are presently no data to indicate how Important it is to them. 


\section{Environmental Consultants}

observed to utilize ridge areas for feeding, although they seek shelter in the more heavily vegetated ravines.

Adjoining areas of chaparral on non-serpentine soil provide habitat for a more abundant and varied fauna. Bird sightings were quite frequent along transects through the non-serpentine chaparral; all bird species encountered were moderately abundant in this plant community. In addition, several other species; including Anna's hummingbird (Calypte anna) and scrub jay (Aphelocoma coerulrscens) were seen. No mamm lsive-trapping was carried out in the nonserpentine chaparral; but the stick nests of the dusky-footed wood rat are noticeably more common here than in serpentine chaparral. This habitat type also seems important to the black-tailed deer population for shelter during the day.

Riparian

The xiparian vegetation of the study area is of critical importance to a number of species of amphibians, reptiles, and birds because of the presence of permanent water and the greater variety of tree and shrub species. The roughskinned newt (Taricha granulosa), Pacific treefrog (Hyla regilla), and yellowlegged frog (Rana boyli1) Iive and reproduce in this zone. The western aquatic gartersnake (Thamnophis coucht) is restricted to this habitat. Birds that depend heavily on streamside vegetation for food or nesting sites or both include several species of woodpeckers, 1 ycatchers, and swallows. Other species characteristic of the riparian community are Steller's jay (Gyanocitta steller1). Swainson's thrush (Catharus ustulata), yellow warbler (Dendroica petechia), black-headed grosbeak (Pheucticus melanocephalus), and lesser goldfinch (Spinus psaltria). During fall and spring migrations and during the winter, additional species such as the varied thrush (Ixoreus naevius) and western tanager (Pinanga ludoviciana), utilize riparian vegetation. The belted kingfisher (Megaceryle alcyon) is found along the larger branches of Alder and High Valiey Creeks, but not on smaller streams. The mammalian fauna are not particularly diversified and mammals do not seem to be particularly numerous In the riparian community, although the burrowing activity of broad-footed moles 


\section{Environmental Consultants}

(Scapanus latimanus), and Botta's pocked $g$ ophers (Thomomys bottae) is quite noticeable.

Woodland

Woodland communities with Douglas fir, yellow pine, madrone, and oaks occur in small patches in noxtheast-facing ravines. These communitles have been subjected to repeated logging and fire which have opened them up to a greater diversity of wildrife species. During the terrestrial phase of their annual cycle (late winter and spxing), rough-skinned newts are quite abundant in this habitat. Other species of amphlbians, including the black salamander (Aneides flavipunctatus), are also expected, expecielly in moist areas around logs and rocks. The gopher snake, common kingsnake (Lampropetltis getulus), and western rattlesnake occur here, along with lizards such as the western skink (Eumeces skiltoniamus) and southern alligatox Ilzard (Gerxhonotus multicarinatus)." A good variety of birds are present, especially in the summer. Raptors would include the sharp-shinned hawk (Accipiter striatus), Cooper's hawk (Accipiter cooperi1), screech owl (Otus asio), and great horned owl (Bubo virginianus). Pileated woodpeckers (Dryocopus pileatus), are expected occasionally, although the woodlands are probably too open for nesting by this species. A list of bird species which typically breed in this habitat is given in Table Small mammal numbers seem moderately high, as Indicated by a yield of 8 rodents of two species from 50 live traps. The pinyon mouse was the most abundant in this sample. Gray Squirrels (Sciurus griseus), are common here, as are duskyfooted wood rats and Botta's pocket gophers. Black-talled deer make extensive use of the woodland margins for daytime shelter, especially where there is a brushy understory.

Table 7. A list of breeding bird species expected in the woodland communities in the vicintty.

Band-tailed pigeon

Hairy woodpecker

Western wood peewee 


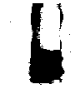

\section{ENVIRONMENTAL REPORT}

Study Area V

City of Calistoga

Prepared under sub-contract to Geonomics, Inc. as part of Phase Zero of the ERDA grant "Alternative Agribusiness and Industrial Uses for Exhaust Heat from Geothermal Waste Fluid, Lake County, California".

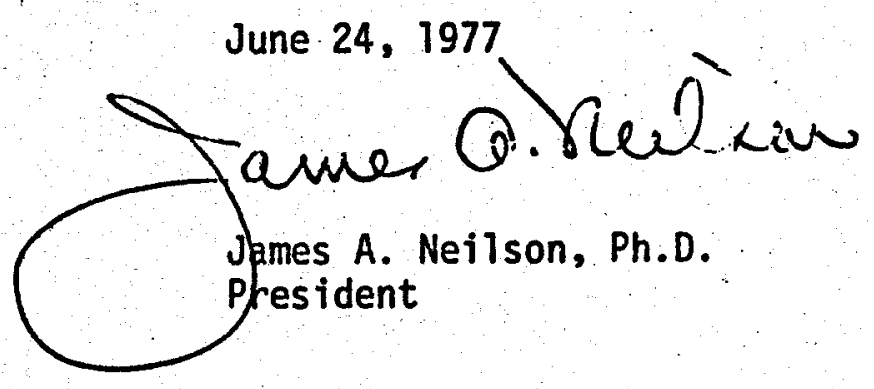


Environmental Consultants

TABLE OF CONTENTS

INTRODUCTION

I. STUDY AREA $V$ - GENERAL ASPECTS

Area Characteristics .

Resource Status

Air Quality

II. THE AIR RESOURCE - STATUS \& QUALITY

Climate

Air Quality

Effects of Non-Electrical Development

III. THE WATER RESOURCES

Water Quality

Effects of Non-Electrical Development

IV. THE VEGETATION RESOURCE

Plant Communities

Environmental Constraints

v. SUGGESTED DEVELOPMENT PLAN
1

4

4

7

7

7

18

20

21

21

21

23

23

24.

25

i 


\section{$b$

FIGURE 1. FLOW DIAGRAM OF CASCADING USES ......... 2 FIGURE 2. LOCALIZED MAPS OF CALISTOGA AREA $\ldots \ldots \ldots . . .3$ FIGURE 3. MAP OF GENERAL AREA $\ldots \ldots \ldots \ldots \ldots \ldots$ FIGURE 4. MONTHLY AVERAGE TEMPERATURES . . . . . . . . 17 FIGURE 5. EVAPOTRANSPIRATION CURVE . .......... 19

\section{LIST OF TABLES}

TABLE 1. CALISTOGA WELL DATA SUMMARY .......... 8-10 TABLE 2. WATER ANALYSIS OF CALISTOGA CITY'S WELLS . . . . 11-12 TABLE 3. CURRENT NON-ELECTRICAL USES OF HOT WATER

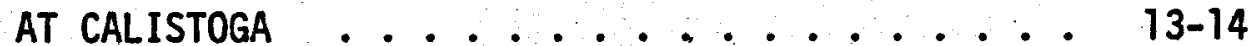




\section{Environmental Consultants}

INTRODUCTION

The attraction for an integrated system of geothermal resource use is predicated on two important environmental problems:

- - The critical shortage of potable and irrigation water in the City of Calistoga and its immediate evirons.

-- The continued random discharge of geothermal waste water into the Napa River, which limits its usability for boron sensitive plants, such as grapes.

The concept presented in Figure 1 is to use the city and well-defined nearby county lands as a heat sink in the form of non-electric applications to cool geothermal water sufficiently to permit water quality improvement systems to upgrade geothermal water for use in the city water supply. Sewage water returned to the treatment plant for tertiary treatment could then be used as a supply for agricultural applications, emergency dilution of geothermal water in times of shortage, ground water recharge, or Napa River water quality maintenance.

The County of Napa is in the process of rezoning land on Tubbs Lane (see Figure 2.) for industrial or geothermal uses. The exact acreage involved is yet unclear, but could range from 50 to 600 acres. The portion having a demonstrated geothermal use is on the order of 50 to 150 acres.

The City of Calistoga has experienced a severe water shortage since June of 1976; various levels of conservation measures have been enforced since that time. Calistoga's reservoirs and wells were at or near capacity during the high rainfall years of 1974 and 1975, but today are very low. Currently, geothermal water is being purified to minimum potable standards for human consumption to supplement the dwindling reservoir supplies. 


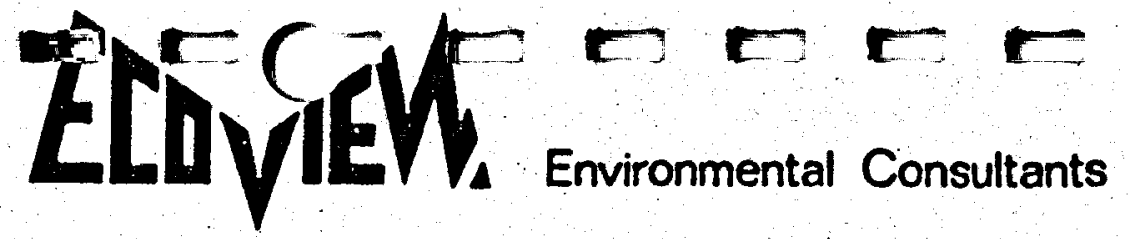

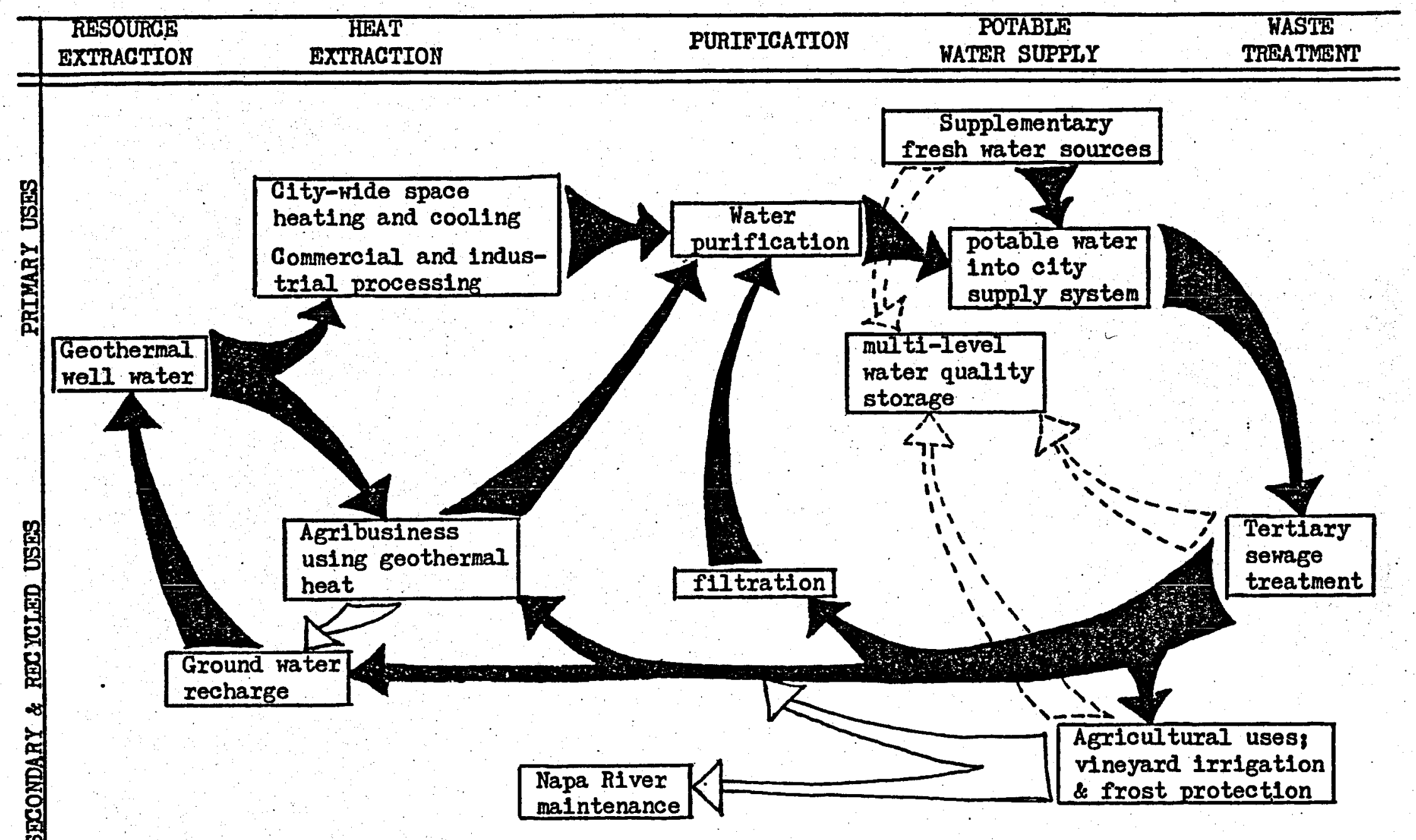

Figure 1. Flow diagram showing cascading uses and recycling loops for the geothermal hot water resource. 


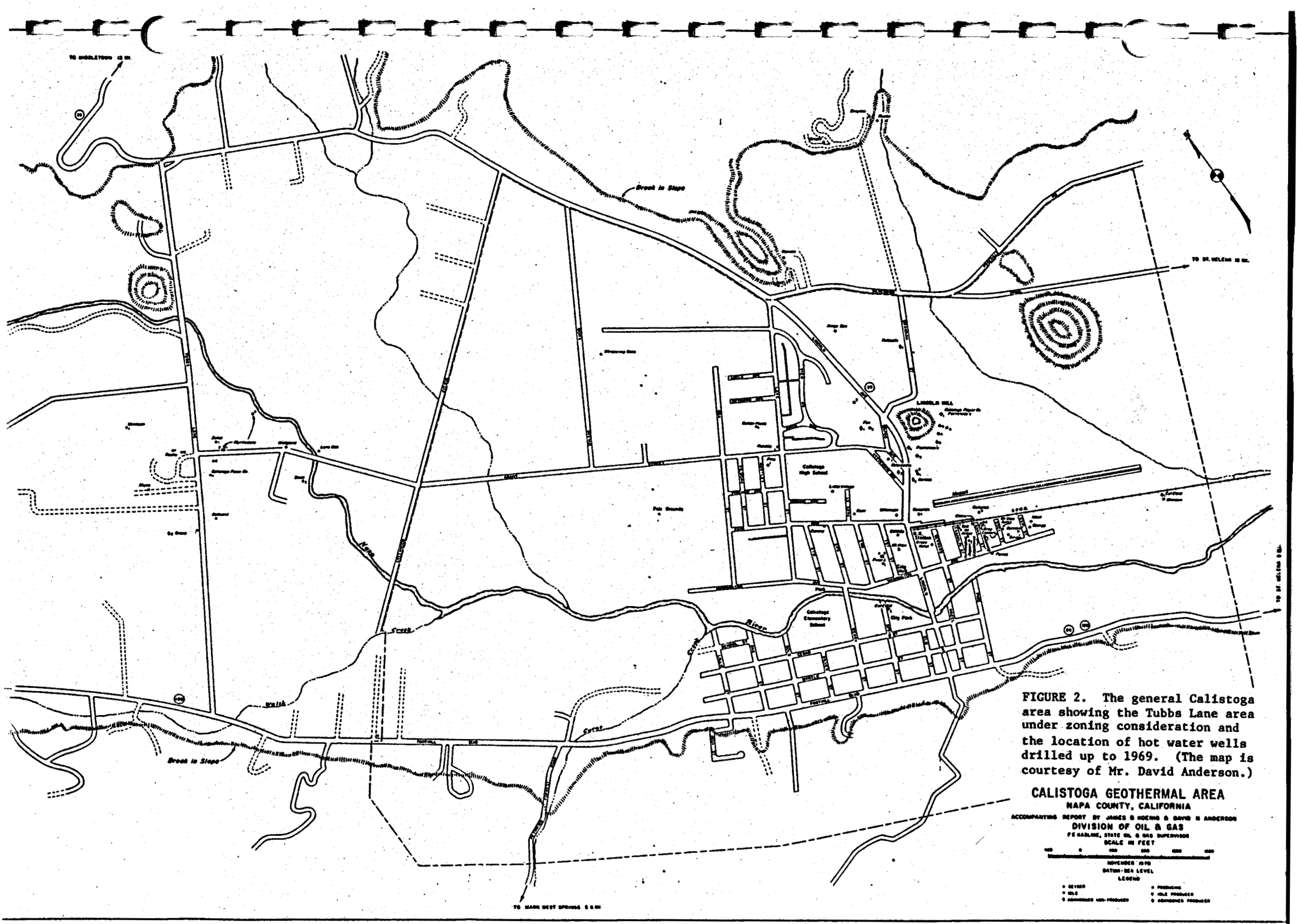


Environmental Consultants

\section{STUDY AREA - GENERAL ASPECTS}

Area Characteristics

The Calistoga area, located in upper Napa Valley, was chosen as an alternate study site because of its long standing development and use of geothermal hot water. The area of particular interest encompasses the old Spanish Grant called Carne Humana and the low relief foothills and tributary valleys immediately adjacent (see Figure 3 ). It comprises between 10 and 13 square miles and is the upper reach of the Napa River. The main Napa valley floor averages $1 \frac{1}{2}$ miles wide and 6 miles long. Its elevation varies between 320 feet at the south to 440 feet in the Bennett Lane area. Its orientation is northwest by southeast and lies in the orographic influence of Mt. St. Helena, which towers 4,000 higher five miles to the north. The City of Calistoga occupies the center of the upper valley and is rural in character. Its population is 3310 persons. The main access routes are State Highways 29 and 128. Highway 29 travels up from the south along the western border of the valley. It passes through town and continues northward into Lake County. Highway 128 continues northwestward from its junction with Highway 29 and leads to Knights and Alexander Valleys in Sonoma County.

There are two jurisdictions involved in this geothermal resource area; the City of Calistoga, comprising of $2 \frac{1}{2}$ square miles or $20 \%$ of the land area,) and the County of Napa. Geothermal resource development has occurred in two areas - one within the city and the other to the northwest on Tubbs Lane on county lands (see Figure 2 ). The two political entities (city and county) potentially have different views on the way in which geothermal development might occur because their interest are divergent and their rules of development appear to be somewhat different. : 


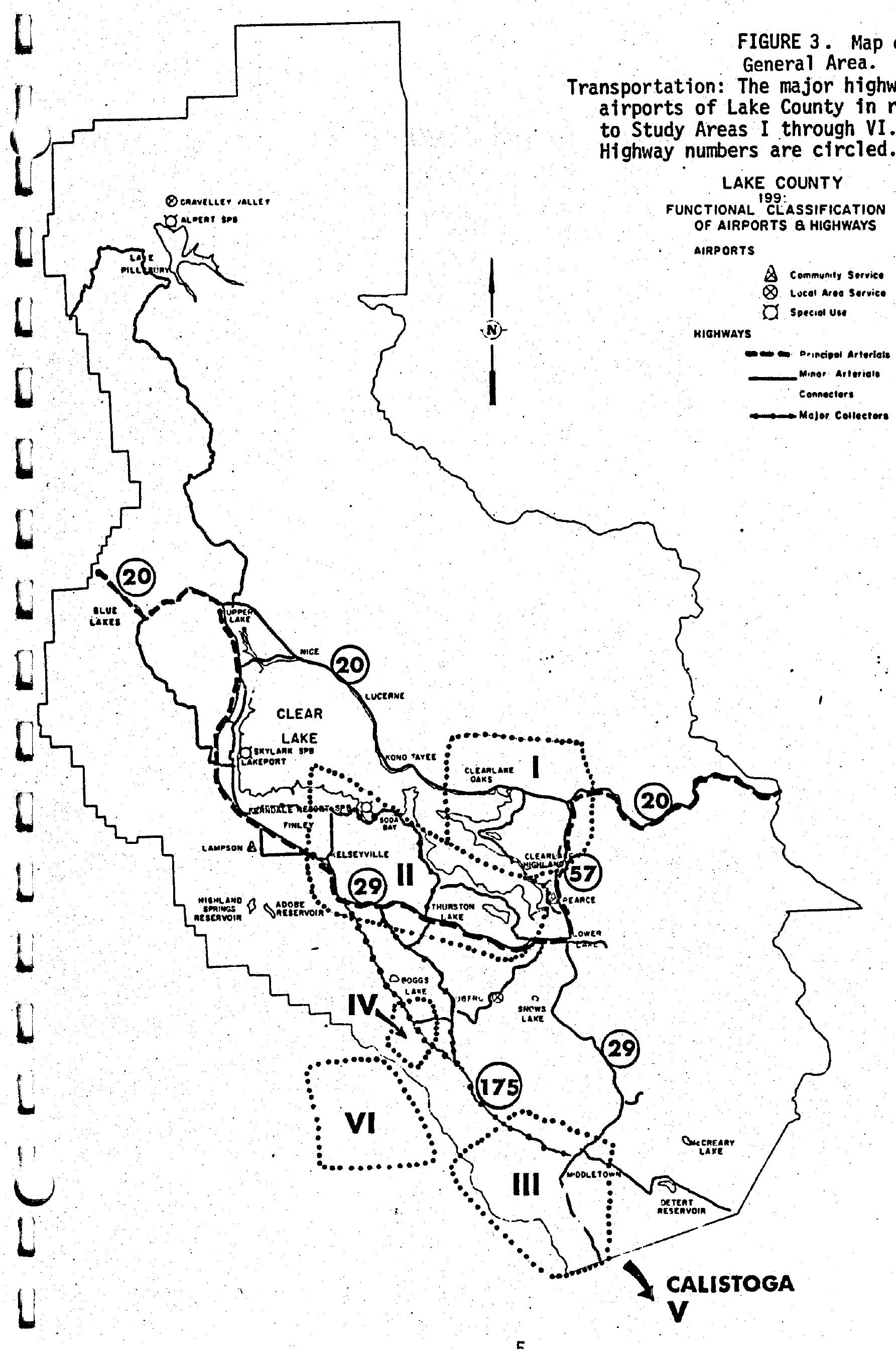




\section{Environmental Consultants}

Agriculture and related support services are the principal land uses in the county jurisdiction, while in the city suburban housing, recreation, and tourism along with minor agriculture are the principal land uses. The population has a large group of Seventh Day Adventists, another of Russian Orthodox and lately an increasing number of Mexican-Americans. The latter are employed in the grape industry. There is an increasing number of retired or semi-retired persons living in the town. Spas and motels enjoy a revival of interest, especially among persons of European extraction who have traditionally used hot mineralized waters for relaxation.

The agricultural base is principally wine grapes of high quality. Several noted wineries (specializing in fine table wines) lie in the immediate vicinity. Some livestock and oat hay are also produced in the area. A few walnut orchards remain from a former era of fruit and nut production. Irrigation is not generally practiced on a large scale, but water is used to establish young grape vines and for vineyard frost protection. Much of the natural underground water sources contain levels of boron well above the tolerance limits of grapes; hence, water holding ponds dot the valley to store run-off waters from creeks.

Originally, Napa Valley was covered with valley oak woodland and savannahs. Only a few stands remain, most having been displaced for agriculture. The surrounding hills support a series of piant comiunities. On north and east facing slopes, Coast Douglas fir forest and woodland dominate; al though because of fire and lumbering much is in a low or mid-successional condition being dominated by live oaks and madrone. Thin rocky soils on south and west facing slopes are occupied by chaparrals and brushlands principally manzanita shrubby live oaks, buck brush, and chamise. Digger Pine-manzanita stands are common and blue oak or mixed oak woodlands occupy lower slopes next to the valley. 


\section{Resource Status}

There is substantial proof of geothermal resources in the area. Table I shows the number of wells, their use as far as known, their depth, and their temperature. Table 2 presents water analysis for the different wells. Table 3 presents background information on two current non-electrical geothermal uses - geothermal greenhouse foliage plants and spas. Figure 2 (map) shows the location of wells up to 1969; however, up to six additional wells have been drilled since that time.

Several elements of the resource are unclear from the geothermal point of view at the present time:

$\therefore$ - The total volume and source of the water being heated.

-- The real nature and location of the heat source.

-- The nature and location of water recharge areas above and below Calistoga that may be needed to maintain flows for current and projected uses.

\section{Area Capability}

Undeveloped land zoned for commercial and industrial applications within the City of Calistoga appears to be sufficient to build and operate small processing applications that would utilize heat.

\section{THE AIR RESOURCE - STATUS \& QUALITY}

Climate

The regional climate affecting the Napa County area is governed by the geographic position of the Central Valley of California, the County's position in the Interior Coast Range, and its proximity to warm water circulation from the Japanese Currents that affect the 


\begin{tabular}{lccccl} 
VELL & DATE & TOTAL & TEMP & PERORMAME & USE \\
\hline Arbour Court & 1956 & $190^{\circ}+$ & 160 & - & baths \\
Brayton 1 & 1930 & $200^{\circ}+$ & 180 & - & wash barrels \\
Bernard 1 & 1965 & $220^{\circ}$ & - & - & hot water \\
Cirios 1 & 1950 & $210^{\circ}$ & - & - & - \\
Coopers 1 & 1930 & $100^{\circ}+$ & - & - & baths \\
Clara 1 & - & - & - & - & baths \\
Casablanca 1 & - & $100^{\circ}+$ & - & - & baths \\
Canary 1 & 1945 & $200^{\circ}+$ & 93 & - & spa and pool \\
Compton 1 & - & - & - & shut-in & - \\
Compton 2 & - & - & - & shut-in & - \\
Calarcadia 1 & - & - & - & - & hot water, baths \\
Calarcadia 2 & -- & - & no heat & - & -
\end{tabular}

Calistoga Mineral

Water Co. 1

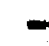

Calistoga Power

Co. 1

n 2

1959

$950^{\circ}$

$1150^{\circ}$

$+\infty$

$\infty$

mineral water

Gity of Calistoga 21965

$540^{\circ}$

1965

$464^{\circ}$

1954

$200^{\circ}$

1968

$300^{\circ}$

$1940 \quad 190^{\circ}$

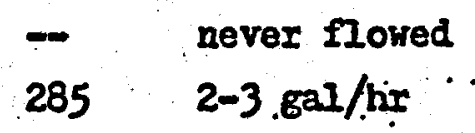

- 3

Crane 1

- 2

Donshick 1

$-\quad-$

Ferros 1

Fox 1

(1) 2

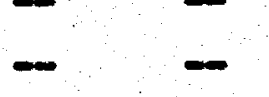

" 3

George 1

Green Hotel

Gray 1

12

Golden Haven 1

1969

$230^{\circ}$

104

$-$

city service

Godward 1

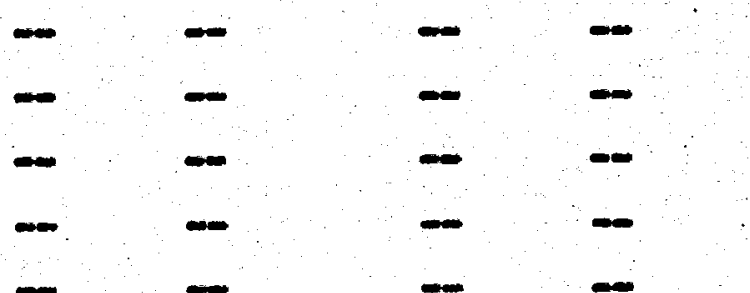

shut-in

Idle

195

$300+$
-

orlginally blex steam

\& bot water, now flow-

Ing hot water 


\section{TABLE 1 (cont.)}

\begin{tabular}{|c|c|c|c|c|c|}
\hline עaT & $\begin{array}{c}\text { DATE } \\
\text { DRIIIED }\end{array}$ & $\begin{array}{l}\text { TOTAT } \\
\text { DEPTH }\end{array}$ & $\begin{array}{c}\text { TEMP } \\
\text { Og }\end{array}$ & PERFORMAMCE & USE \\
\hline Hummingbird 1 & - & - & - & - & hot water \\
\hline Hollday 1 & - & - & - & - & baths \\
\hline Ideal & - & - & - & - & hot water \\
\hline Kings Spa & 1940 & $300^{\prime}$ & 180 & - & baths \& pool \\
\hline Iittle Village Inn & - & - & - & - & hot vater \\
\hline Ione Oak 1 & - & - & 140 & - & - \\
\hline HountainViek Apts 1 & $1-$ & - & - & - & hot water \\
\hline Mt. VLew 1 & 1936 & $260^{\circ}$ & - & - & hot water \\
\hline Myrtledale 1 & 1940 & $150^{\circ}$ & 225 & - & spa \\
\hline 12 & - & - & - & - & spa \\
\hline - 3 & - & - & - & Idle & mineral baths \\
\hline Nances 1 & 1920 & $240^{\circ}$ & 218 & - & spa \\
\hline 12 & 1920 & $200^{\circ}$ & 218 & - & $\infty$ \\
\hline - 3 & 1935 & $60^{\circ}$ & 140 & - & $\therefore$ \\
\hline OrIoff 1 & - & $200^{\circ}$ & $200 t$ & $\infty$ & pool. \\
\hline Piner's 1 & - & $50^{\circ}$ & 130 & - & hot water \\
\hline 2 & 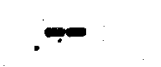 & - & - & Ide & $\infty$ \\
\hline a 3 & - & - & $\therefore$ & Idle & - \\
\hline Plne 1 & 1959 & $230^{\circ}$ & 166 & $\infty$ & baths \\
\hline Pachoteau's 1 & 1940 & $\dot{m}$ & - & abandoned & - \\
\hline 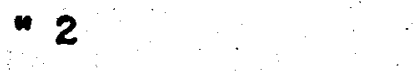 & 1900 & - & - & abandoned & - \\
\hline 3 & 1920 & - & $\because$ & display & $-\infty$ \\
\hline " 4 & 1920 & $152^{\circ}$ & - & $-\quad \quad$ & spa, steam, hot \\
\hline 45 & 1919 & 164 & 210 & $-\infty$ & \\
\hline
\end{tabular}

MOIE No. 4 \& 5 will produce $1 / 4$ million gallons in 12 hours

6

Raahe 1

Rashe 1

- 2

3

Reysen 1

\section{$1919 \quad 178^{\circ}$}

- $\quad-$

$-\quad 350^{\circ}$

$-\quad 300^{\circ}$

1950

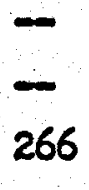

350

$-$
-

Idle

natural geyser, 4000 display gal/min while eruptIng every $40 \mathrm{~min}$ erupts every 20 min. hot water unless capped

erupted but closed -

itself off

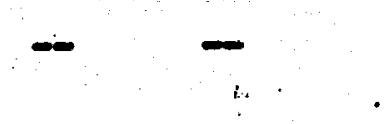

$\infty \quad \therefore$

baths 


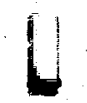

\section{TABLE 1 (cont.)}

\begin{tabular}{|c|c|c|c|c|c|}
\hline HELL & $\begin{array}{c}\text { DATE } \\
\text { DRTLIED }\end{array}$ & $\begin{array}{l}\text { TOTAL } \\
\text { DEPTH }\end{array}$ & $\begin{array}{c}\text { TENP } \\
O_{\mathrm{F}}\end{array}$ & PERFORMANCE & USE \\
\hline Spa 1 & 1960 & - & 180 & - & baths \& pool \\
\hline$n 2$ & 1960 & $220^{\circ}$ & 180 & - & baths \& pool \\
\hline Sakal 1 & 1945 & $100^{\circ}+$ & 220 & - & Ereenhouse \\
\hline Saka1 2 & $\begin{array}{l}1962 \\
\text { well }\end{array}$ & $\begin{array}{l}500 \\
\text { oduces }\end{array}$ & $\begin{array}{l}180 \\
\text { that }\end{array}$ & I burn - methane? & Ereenhouse \\
\hline Sykes 1 & 1945 & $200^{\circ}$ & 180 & - & pool \\
\hline Tedesch1 1 & 1900 & $75^{\circ}$ & - & shut-in & - \\
\hline Unknown 1 & 1945 & $100^{\circ} ?$ & 120 & flowing slightly & \\
\hline 2 & - & - & - & - & - \\
\hline Wizkinson 1 & 1952 & $190^{\circ}$ & $212+$ & - & spa \\
\hline Hispering Oaks 1 & 1950 & $150^{\circ}$ & - & - & baths \& pool \\
\hline Mielgard 1 & 1950 & $100^{\prime} t$ & $100 t$ & - & pool \& hot water \\
\hline
\end{tabular}




\section{$E[a$ VIE. Enviromental Consultants}

TABLE 2

WATER ANALYSIS OF CALISTOGA CITY'S WELLS

Fiege Well \#4 ${ }^{1} \quad$ Pacheteau's Well ${ }^{2} \quad$ Gity Park Well 3

\begin{tabular}{|c|c|c|c|}
\hline Temperature. & $90-110^{\circ} \mathrm{F}$ & $180^{\circ} \mathrm{F}$ & $123^{\circ} \mathrm{F}$ \\
\hline $\mathrm{pH}$ & 7.5 & 9.1 & 8.4 \\
\hline Flow rate & $240,000 \mathrm{gal} / \mathrm{day}$ & $250,000 \mathrm{gal} / \mathrm{day}$ & $216,000 \mathrm{gal} / \mathrm{day}$ \\
\hline Total hardness & $66 \mathrm{mg} / 1$ & $13 \mathrm{mg} / 1$ & $20 \mathrm{mg} / 1$ \\
\hline Ca hardness & $52 \mathrm{mg} / 1$ & & $12 \mathrm{mg} / \mathrm{I}$ \\
\hline Mg hardness & $14 \mathrm{mg} / \mathrm{I}$ & & $8 \mathrm{mg} / 1$ \\
\hline TDS & $250 \mathrm{mg} / \mathrm{I}$ & $657 \mathrm{mg} / \mathrm{I}$ & $680 \mathrm{mg} / 1$ \\
\hline Total alkalinity & $140 \mathrm{mg} / \mathrm{l}$ & $102 \mathrm{mg} / 1$ & $200 \mathrm{mg} / \mathrm{l}$ \\
\hline Specific cond. & 325 micromhos & 876 umhos/cm @ 250 & 800 \\
\hline Turbidity & 2.4 turb. units & & \\
\hline Ag & & $0.01 \mathrm{mg} / 1$ & $0.005 \mathrm{mg} / 1$ \\
\hline As & $0.078 \mathrm{mg} / \mathrm{l}$ & $0.12 \mathrm{mg} / 1$ & $0.25 \mathrm{mg} / \mathrm{l}$ \\
\hline B & $0.31 \mathrm{mg} / 1$ & $11.6 \mathrm{mg} / 1$ & 12. $\mathrm{mg} / 1$ \\
\hline $\mathrm{Ba}$ & $0.077 \mathrm{mg} / 1$ & & $0.05 \mathrm{mg} / 1$ \\
\hline $\mathrm{Ca}_{2}$ & $21 \mathrm{mg} / 1$ & $5.0 \mathrm{mg} / 1$ & $4.8 \mathrm{mg} / 1$ \\
\hline Gd & $0.002 \mathrm{mg} / \mathrm{l}$ & & $0.001 \mathrm{mg} / 1$ \\
\hline Cl & $6.0 \mathrm{mg} / 1$ & $215 \mathrm{mg} / 1$ & $170 \mathrm{mg} / 1$ \\
\hline Cn & $0.01 \mathrm{mg} / 1$ & $\therefore \quad \cdot$ & \\
\hline $\mathrm{CO}_{3}$ & 0 & $43 \mathrm{mg} / 1$ & $8.0 \mathrm{mg} / 1$ \\
\hline $\mathrm{Cr}^{\prime}$ & $0.012 \mathrm{mg} / \mathrm{I}$ & $0.001 \mathrm{mg} / \mathrm{I}$ & $0.01 \mathrm{mg} / \mathrm{l}$ \\
\hline $\mathrm{Cu}$ & $0.012 \mathrm{mg} / 1$ & & $0.006 \mathrm{mg} / \mathrm{I}$ \\
\hline $\mathrm{Cy}$ & & & $0.1 \mathrm{mg} / \mathrm{l}$ \\
\hline$F$ & $0.28 \mathrm{mg} / 1$ & $10.4 \mathrm{mg} / 1$ & $9.7 \mathrm{mg} / 1$ \\
\hline $\mathrm{Fe}$ & $0.63 \mathrm{mg} / 1$ & $0.02 \mathrm{mg} / 1$ & $0.32 \mathrm{mg} / 1$ \\
\hline $\mathrm{HCO}_{3}$ & $170 \mathrm{mg} / \mathrm{l}$ & $37 \mathrm{mg} / \mathrm{l}$ & $234 \mathrm{mg} / \mathrm{l}$ \\
\hline $\mathrm{Hg}$ & $0.001 \mathrm{mg} / \mathrm{I}$ & $0.0002 \mathrm{mg} / \mathrm{l}$ & $0.01 \mathrm{mg} / 1$ \\
\hline Mg & $3.4 \mathrm{mg} / 1$ & $0.05 \mathrm{mg} / \mathrm{l}$ & $1.9 \mathrm{mg} / 1$ \\
\hline Mn & $0.11 \mathrm{mg} / \mathrm{l}$ & $0.01 \mathrm{mg} / \mathrm{l}$ & $0.09 \mathrm{mg} / 1$ \\
\hline $\mathrm{N}$ & & $0.02 \mathrm{mg} / 1$ & \\
\hline $\mathrm{Na}$ & $56 \mathrm{mg} / 1$ * & $208 \mathrm{mg} / 1$ & $150 \mathrm{mg} / \mathrm{I}$ \\
\hline K & & $9.9 \mathrm{mg} / 1$ & $14 \mathrm{mg} / \mathrm{l}$ \\
\hline
\end{tabular}

* includes $\mathrm{K}$ 
EI VI. Environmental Consultants

\begin{tabular}{l|lll}
$\mathrm{NO}_{3}$ & $0.44 \mathrm{mg} / 1$ & $0.02 \mathrm{mg} / 1$ & $0.1 \mathrm{mg} / 1$ \\
$\mathrm{P}$ & $0.02 \mathrm{mg} / 1$ & & $0.01 \mathrm{mg} / 1$ \\
$\mathrm{~Pb}$ & $0.096 \mathrm{mg} / 1$ & & $0.29 \mathrm{mg} / 1$ \\
$\mathrm{Se}$ & & $130 \mathrm{mg} / 1$ & \\
$\mathrm{Si}$ & $34 \mathrm{mg} / 1$ & $4.8 \mathrm{mg} / 1$ & $1.6 \mathrm{mg} / 1$ \\
$\mathrm{SO}_{4}$ & $0.19 \mathrm{mg} / 1$ & & $0.011 \mathrm{mg} / 1$ \\
$\mathrm{zn}$ & &
\end{tabular}

1. Four wells near Fiege Reservoir are used as a source for city water. This water must be treated for iron and mangenese. Depths range from 340 to $460^{\prime \prime}$. Drilling logs are available. Analysis done on well \#4 in 1976.

2. Wells have been tested by Kennedy Engineers, Inc. for City of Calistoga to determine the acceptability of water as emergency source of potable and irrigation water. The report is available from the city. Analysis done 1976.

3. Analsis done 1977 .

$-12-$ 
TABLE 3

CURRENT NON-ELECTRICAL USES OF HOT WATER

NANCES

AT CAIISTOGA

HATER ANALYSIS

Calcium sulphate

Magnesiun sulphate

Sodium sulphate

Total Solids

Iron \& aluminum

Silica

- Sodiun chioride

Fixed Sollds
QUANTITATIVE GRAIRS IN U.S. GATION

1.21.

0.30

5.28

39.87

0.17

8.35

19.99

37.60

CAIISTOGA SPA HOT SPRIMGS RESORT

-4 wells ( 2 hot, 2 cold)

(pools, baths, space heating)

$$
\begin{aligned}
200^{\circ} & =1900 \mathrm{~F} \\
50-80^{\circ} & =90^{\circ} \mathrm{F}
\end{aligned}
$$

WATER ANATISIS (ppr)

Calcium sulphate

13.08

Calcium phosphate

0.18

Magnesium sulphate

7.05

Sodtum bicarbonate

214.0

Sodium chloride

302

Potassium chloride

16.7

Potassium lodide

.12

Iithium chloride

11.03

Sodium borate

trace

Colloldal silica

144.06 
TOM GRANE

VES SARAI
GREERHOUSE OPERATION ON TUBBS LAANE

2 wells, one an artesian, 30 to $50^{\circ}$ deep, $180^{\circ} \mathrm{F}$

13' Iift from well

-uses heat exchanger (down hole) wt th blowers for air circulation

$-5500 \mathrm{sq} \mathrm{ft}$ of greenhouse in tropical plants

-reports boron problem; carbonate precipitates if wders used directiy

-water analysis now being done

$$
\text { GRERMTOUSE OPERATION ON TUBBS IANE (707-942-6293) }
$$

3 wells (Artestan)

(1) $50^{\circ}=90-100 \%$

(2) $75^{\circ}=3250 \mathrm{~F}$

(3) $500^{\circ}=195 \%$

(natural gas present)

$-10,000$ sq $\mathrm{ft}$ of gxeenhouse in follage plants, uses underground piping system

-2 wells produce $120 \mathrm{gal} / \mathrm{min}, 8 \mathrm{hrs} / \mathrm{day}$ (night only)

-reports $15 \mathrm{ppm}$ boron in water, also in soil

-water analysis being done.

-reports UCD studs of his operation about 6 years ago 


\section{Environmental Consultants}

California coastline. The rainy season begins on or shortly after the autumnal equinox; and under usual atmospheric conditions, ends about the time of the vernal equinox.

As a general rule, winter storms are generated along the interface - between the Canadian-Arctic air mass and the warmer Pacific oceanic and Western North American continental air masses of the temperate zones. Cyclonic storms are normally generated in the Gulf of Alaska. They move in an easterly direction, but because of the interference of the St. Elias and Rangell Ranges on the coast of southern Alaska and British Columbia, these storms are directed to a more southerly route across lower British Columbia and the Pacific Northwest. Depending upon their point of origin and the position of the jetstream, the storm paths tend to concentrate in Washington and Oregon with only the deepest and most extensive storms, reaching into Central and Southern California.

The jetstream has an apparent long-range effect by dictating, to a considerable degree, the beginning and intensity of rainy periods. These rainy periods may begin as early as the middle of September or as late as the end of December; however, in genera1, the first deep cyclonic storm occurs between the 26th of September and the 15th of November. There is a fall rain period and a spring rain period, both of which are unpredictable in their beginning and ending. When the precipitation patterns are plotted on the basis of five to eight year periods, a bimodal curve is usually apparent. Longer periods, however, equalize this pattern into a unimodal curve whose mode falls in December.

Following the vernal equinox, precipitation rapidly declines; and usually, from the period beginning about the 25th of June to the 


\section{Environmental Consultants}

25th of September, the probability of rain in Napa County is extremely low. This sumer drought period is accompanied by temperatures with daily maximums ranging between $75^{\circ} \mathrm{F}$ and $105^{\circ} \mathrm{F}$ (data from California Weather Summary, U. S. Weather Bureau).

This general pattern is occasionally modified by a change in the position of the jetstream; when this stream moves northward, the local climate can be considered mild. The cyclonic weather system precipitates about 33 inches of rainfall annually in the winter period snow rarely falls on the valley floor.

Temperature extremes are $11^{\circ} \mathrm{F}$ in winter and $114^{\circ} \mathrm{F}$ in summer, although the daily temperatures are much milder than the extremes. Average January temperatures are $56^{\circ} \mathrm{F}$ maximum and $36^{\circ} \mathrm{F}$ minimum, and July temperatures are $88^{\circ} \mathrm{F}$ maximum and $52^{\circ} \mathrm{F}$ minimum (Figure 4 ).

The intense ground heating in the summer, typical of much of the interior coast range, is ameliorated by the cool ocean breezes in midafternoon. These sweep up the Napa Valley from the Carquinez Straits and to a lesser extent blow directly over the mountains from the sea. These breezes are a result of cool ocean air flowing inland to fill the void left by hot rising air in the Sacramento-San Joaquin Valley.

The, atmospheric conditions combine to form a moderately cool region, having 2500 to 3000 degree days of heat from April 1 to October 31 , and are responsible for the production of grapes yielding unusually fine table wines for which the Calistoga-St. Helena-RutherfordYountville area is so famous.

The interrelationship between temperature and moisture regimes sets the basic requirements for plant growth. Optimum growing temperatures are not always accompanied with available moisture, and the St. Helena area is no exception to the general rule of Northern California. 


\section{Environmental Consultants}

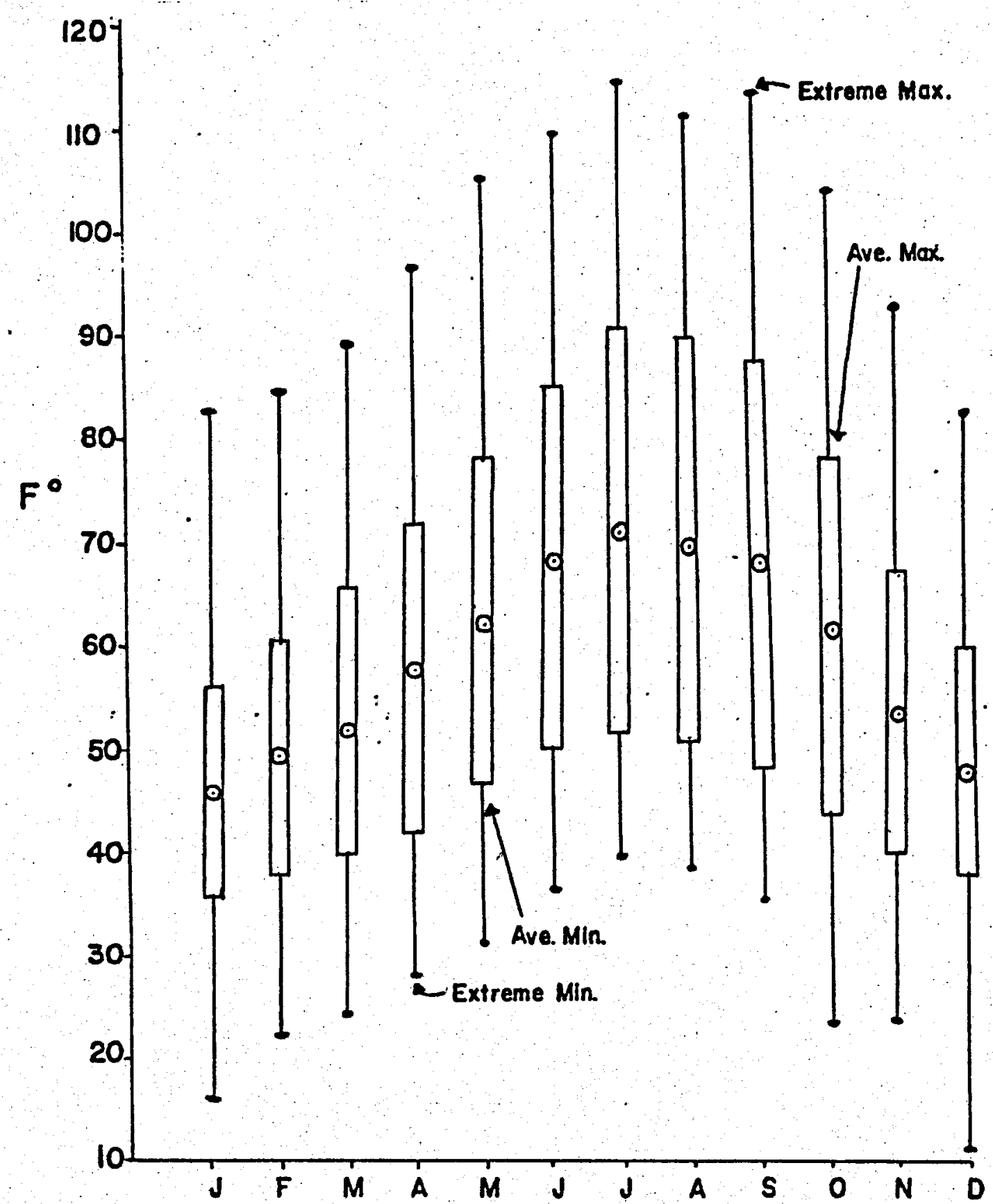

Figure 4. Monthly average temperature ranges at St. Helena (30 years of record). The extremes of temperature and the frequency of their occurrence are of critical importance to plants in general and viticulture in particular. 


\section{Environmental Consultants}

Figure 5 graphically portrays the relationship between occurrences of precipitation (winter) and the accumulation of heat (summer). There are four critical periods of moisture conditions: 1) water deficit, 2) water surplus, 3) soil moisture utilization, and 4) soil moisture recharge. The potential evapotranspiration (P.E.) curve represents the heat factor of the environment that promotes evaporation and forces plants to transpire water in order to survive. The intensity of this factor depends principaliy on the amount of sun's heat and the relative humidity. The ability of plants to survive during the dry summer period depends upon the amount of soil moisture available to plants. When soil moisture is depleted the plants either die or go dormant. Modifications of this soil moisture supply are dependent on the volume of the soil column, water-holding capacity of the soil, height of water table, and depth of plant roots.: Soil moisture is depleted by the first of July for most plants. Deep-rooted plants such as trees and late summer weeds like tarweed (Hemizonia sp.), star thistle (Centauria sp.) tap lower volumes of soil and therefore thrive in otherwise water deficits. Grapes fall into this latter group of plants, but the deep soil and relatively high water table $\left(6^{\prime}\right.$ to $\left.1^{\prime}\right)$ under soils in the Napa Valley make it particularly desirable because irrigation is usually unnecessary except to cool the plants and reduce the transpiration pull on ground water supplies.

Air Quality

Very little actual data is available regarding the air quality resource in the upper end of the Napa Valley. Principal contaminant sources include automobile exhausts from traffic on Highway 29 and 128, small amounts of $\mathrm{H}_{2} \mathrm{~S}$ from geothermal wells, and dust generated largely from agricultural activity. Air flow patterns have not been studied in detail, but the northwest - southeast valley winds are locally modified by Mt. St. Helena. 


\section{FIM Environmental Consultants}

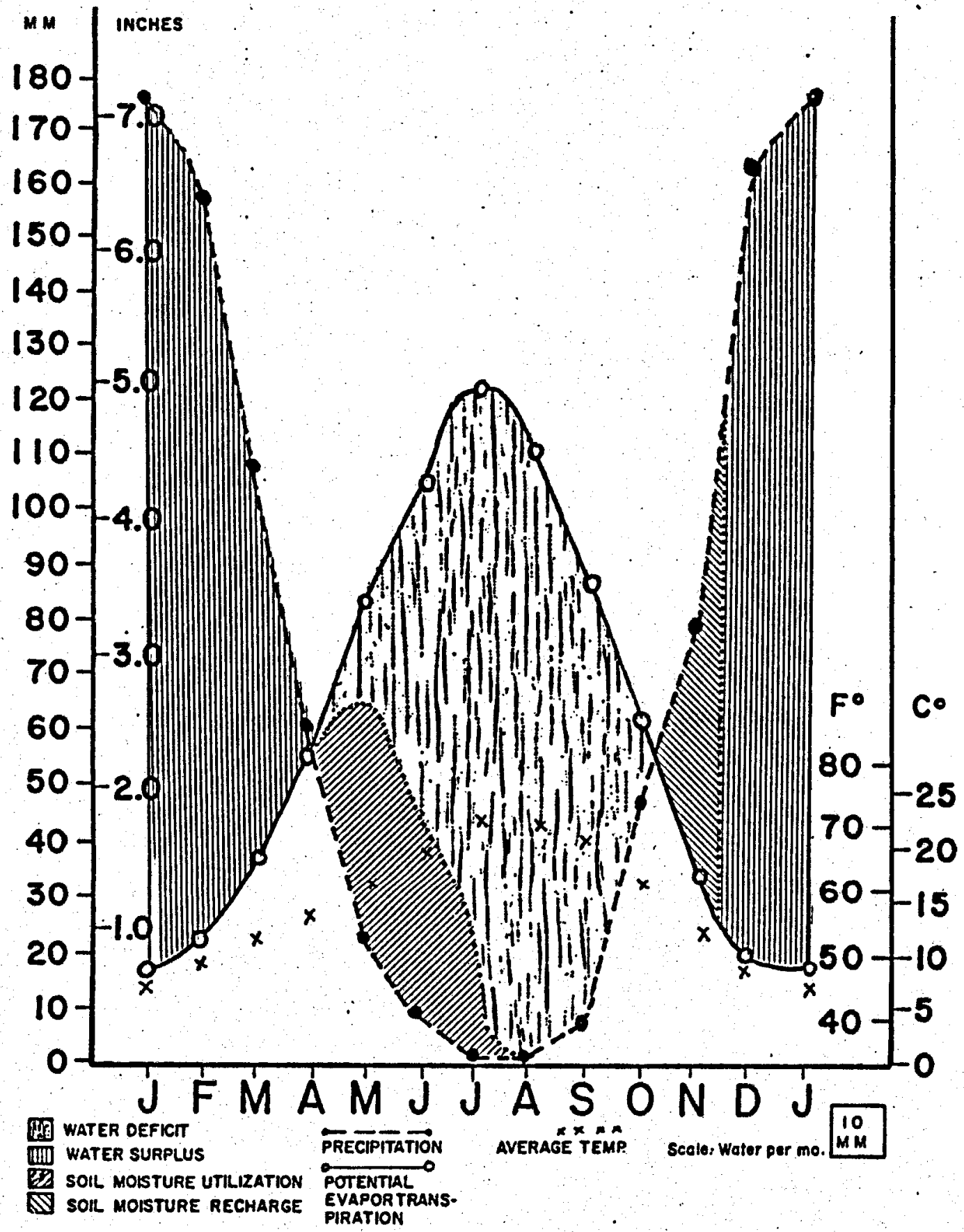

Figure 5. - Potential evapotranspiration curve in relation to precipitation, temperature, and soil moisture. Cessation of rainfall in spring months is only partially offset by soil moisture. When the latter is exhausted drought occurs. Early. rains replenish soil moisture then a surplus exists in the environment. Soll moisture capacity was arbitrarily chosen at $100 \mathrm{~mm}$ but Napa County soils vary from 25 to $300 \mathrm{~mm}$. 


\section{Environmental Consultants}

Northerly flows of air passing through the Geysers geothermal area may transport $\mathrm{H}_{2} \mathrm{~S}$ generated there into the Napa Valley. These concentrations are estimated to be on the order of 5 to $10 \mathrm{ppb}$ (parts per billion) up to 1976 when the abatement programs of P. G. \& E. power plants began to take effect. As more of the geothermal power plants are retrofited with abatement devices, this transport level should drop to 2 to $6 \mathrm{ppb}$ for at least one and a half decades. Assuming current practices continue slight increases may be noticed as the size of the field increases. Several abatement techniques are now being developed by the industry so that this factor may not be important in the future.

Northerly air flow from the Bay Area brings somewhat contaminated air from many sources to the south. These currents occur on surmer afternoons. and during winter cyclonic weather patterns. These currents are well mixed by the time they reach the upper valley and nuisance or health hazard levels are rarely attained. Hence, the current status of air quality in the Calistoga area can be assumed to be good. and without significant local contributing contaminant sources.

\section{Effects of Non-Electrical Development}

The impact of extensive non-electric uses on air quality should be minimal unless manufacturing or chemical processing applications are developed. Such activities will need to be carefully scrutinized in the use permitting procedures, especially as they might affect agricultural growth. Similiarly, the stimulation of substantial traffic loads in the area may create local smog or $\mathrm{SO}_{2}$ levels if levels of $\mathrm{H}_{2} \mathrm{~S}$ are allowed to increase in the area. (cf. Neilson et al 1975 EIR. for Borax Lake, Lake County, California). 
III. THE WATER RESOURCES

Water Quality

The principal source of high boron levels in Napa River water arises from the discharge of geothermal fluids into streams in the Calistoga area. This largely prevents its use for irrigation down valley, except to withdraw and store water during periods of high natural flows that dilute the concentration to acceptable levels. The impact of geothermal development w111 depend upon the extent of total extraction, whether or not it is cleaned up before discharge, and the way it is disposed of when the heat has been extracted. The area could sustain a moderate increase of discharge without significant adverse impacts, but extensive use (i.e., above $15 \%$ of current volume of extraction) will cause problems locally and downstream if current discharge systems are allowed to continue.

\section{The Effects of Non-Electrical Development}

Impacts can develop from the following sources:

-- Ground water recharge

-- Permiscuous surface discharge of untreated waters onto land or into streams

- Waste water bearing high nutrient levels from livestock or other commercial operations

-- Heavy withdrawal of geothermal waters that might tend to concentrate minerals within the reservoir

Clearly, the reinjection of geothermal waters into aquifers flowing into or over the heat source will eventually increase the concentration of those minerals. Hence, until the hydrology of the area and its relationship so the heat resource is known much more clearly than it presently is, the placement of untreated spent geothermal fluids into 
ground water recharge areas is a questionable practice. Deep reinjection i.e., to levels below $5,000^{\prime}$ for instance may be acceptable but this may reduce the capacity of the field.

Permiscuous discharge of fluids onto lands, especially class two soils, will eventually increase boron levels (as well as other contaminants) to levels that will impair or inhibit plant growth. Viewing the range of variation in mineral content of wells currently used, it appears that those discharging over $15 \mathrm{mg} / 1$ boron should be closed down or no discharge permitted.

Systems for extracting boron even on a small scale are well known, but they are not widely applied because most communities have water sources that do not present a problem. In our opinion the extensive use of .. geothermal fluid anywhere in the Geysers KGRA will depend upon the economics and ability to remove these contaminants on a large scale. Hence, we are suggesting one or more plants especially devoted to water treatment (see figure $\mathbf{Z}$ ) to remove these contaminants to acceptable levels.

Another source of water quality degradation might arise from the discharge of waste water that contains either geothermal fluids and animal excretion or waste from processing operations. These sources, while potentially useable either for reclaimation of minerals or as nutrients for feed or fertilizer, can cause considerable problems to surface waters and to shallow aquifers. It may well cause extensive eutrophication of streams and storage ponds, as well. These problems can be handled by sewage treatment and/or the water reclaimation facilities suggested. Substantial hot water withdrawal could lower flow rates or natural reservoir levels to the extent that dissolved minerals become more concentrated. Not only could this affect local water quality, but it could adversely affect the flow of water through or over the heat resource diminishing its life and potential sustained production. Excessive extraction of geothermal fluids may also cause ground 


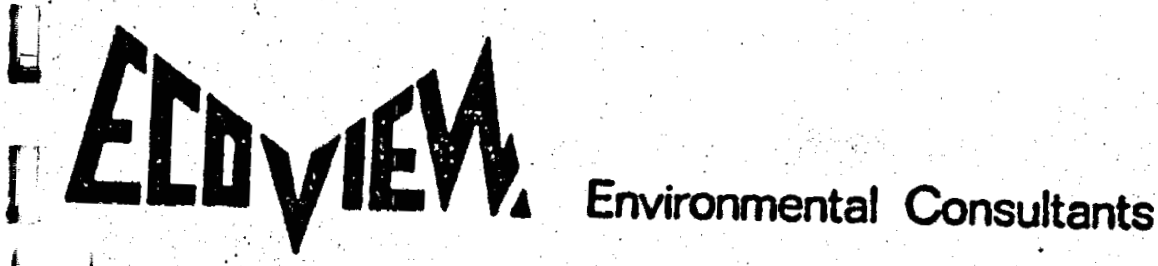

subsidence. To prevent the latter, ground water recharge may be essential but again a thorough knowledge of the hydrology of the area is essential.

\section{THE VEGETATION RESOURCE}

\section{Plant Conmunities}

No definitive study of vegetation has been completed for the Upper Napa Valley. However, within the study area the following observations are appropriate.

Riparian vegetation is essential for both erosion control and wildlife habitat. These communities may consist of willow (Salix laevigata, S. goodingii and S. laisocarpa), alder (Alnus rhombifolia), box elder (Acer negundo), bay (Umbellularia californica) and oak (Quercus wislizenii, Q. agrifolia, and Q. lobata). Occasionally big-leaf maple. (Acer macrophyllum) and sycamore (Platanus racemosa) occur. Shrubby undergrowth includes coyote brush (Bacharus pilularis), manzanita (Arctostaphylos manzanita) and the native grape vine (Vitus californica). The herbaceous understory is very variable but important plants include wormwood (Artemisia ludoviciana), wild rye grass (Elymus glauca or E. triticojdes), and various sedges and rushes.

At one time, much of the valley floor was covered with valley oak woodland and savannah. Today only a few stands remain of either; these are located mostly along streams. These communities occupied much of the land now devoted to intensive agriculture. Blue oak woodland (Quercus douglasii) occupies the drier foothills along the margin of the valley, but even many of these communities have been displaced by agricultural crops. 
In the area occupied by the Bale Complex soils in the vicinity of Tubbs Lane, a salt marsh occurs. A dense stand of rushes flourishes, but mostly salt tolerant grasses such as Distyclis spicata and Hordeum depressum are common. Cattails are found where standing water prevails, but over most of the area there is a curious mixture of weedy plants, California introduced annual grassland, and native perennial grasses. These distribute themselves according to drainage of water, concentration of salts, and local elevation.

Agricultural crops are mostly grapes, walnuts, a few prunes, native or oat vetch hay, a little irrigated pasture, and some non-irrigated pasture land.

\section{Environmental Constraints}

Geothermal development should be restricted from riparian areas and the remaining valley oak woodland. The most appropriate areas for initial geothermal development are the Coles Silt Loam and Bales Clay Loam soils in the vicinity of Tubbs Lane.

Any displacement of other agricultural crops should be considered on the basis of current land use, available geothermal resource, possible aesthetic and land use conflicts on a case-by-case basis. As suggested in the following section, a general plan for geothermal. development should be developed at an early stage so that appropriate land uses are made. 
Environmental Consultants

V. SUGGESTED DEVELOPMENT PLAN FOR GEOTHERMAL USES IN THE CALISTOGA AREA

Because of the great necessity for integrated use of the geothermal resource in the city and county, we urge the consideration of a resource management plan that embodies the features and topics outlined below. These topical segments pertaining to the orderly development of the hot water geothermal resource in the Calistoga area, should be carefully integrated and sequentially arranged in order to develop a plan of action that is consistent with city and county general plans and with acceptable environmental standards for the area. These topics include, but are not necessarily limited to:

Political

Socio-economic

Geotechnical

Environmental Planning

Engineering

Economic Feasibility

Construction

Operation

On the following pages, several of the above topics are broken down into a number of elements that can readily be identified as inmediately applicable to the area. However, any development or plan should be taken in the context of the County Geothermal Resource Impact Planning Study (GRIPS). 
Environmental Consultants

\section{Political Objectives}

1. Define and establish an equitable method of unifying development of the resource. This means that ownerships is pooled and the extraction regulated but the benefits prorated to all property owners.

2. A workable relationship between the county and city that unifies and integrates development planning.

3. Establish a workable relationship with the GRIPS program.

4. Determine and facilitate methods of finance of municipal and public elements of the development.

Environmental Objectives

1. Establish and define land sensitivity. Topics of particular interest that require specific identification include, but are not limited to:

Riparian and flood plain

Urban and suburban residential areas

Archaelogical and historical sites

Prime agricultural land

Aesthetics and quality of life

These elements may preclude development in certain areas or initiate changes in land use because of resource location. 


\section{ELD VIE}

\section{Geotechnical Objectives:}

1. Determine the morphology and areal extent of the reservoir in the valley floor and adjacent foothills of the Northern Napa Valley embracing the Carne Humana Grant and including \pm 10 to 13 square miles.

2. Determine the relationship of surface hot water to the deep reservoir underneath, if such exists.

3. Determine the source, flow pattern and flow rate of the aquafero bearing hot water now being tapped.

4. Determine the necessity and implications of ground water recharge to maintain the hot water flow and, if necessary, determine the point or points of recharge.

5. If necessary, determine the implications of deep injection of highly boronated waters and its implications

6. Determine the capacity of the reservoir in the surface 400 to $2000^{\prime}$ and the capacity and nature of the resource at greater depths.

7. Determine the potential for subsidence for shallow extractions ( 0 to $\left.2000^{\prime}\right)$ of large scale commercial use. Determine mitigations to offset or negate adverse effects.

8. Outline the best placement of wells, depth of drilling, and rate of extraction to yields a sustained production measured in centuries that also can be related to land surface capability. 


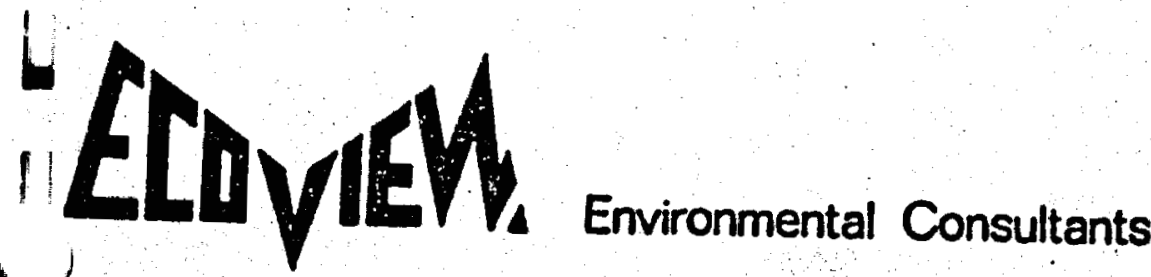

\section{Engineering Objectives}

1. Analyze and design water collection of system to transport spent geothermal water to water reclaimation plant. Includes cost analysis.

2. Design and cost-out construction and operation of water. reclaimation plant.

3. Establish engineering parameters necesary to incorporate existing municipal water system, sewage, water storage, water transport to irrigation and reservoir recharge areas and solid waste disposal or reclaimation.

4. Establish physical and economic feasibility and desing of space heating and cooling system - large energy users vs. municipal utility.

5. Design and adapt interconnections for agricultural and commercial use systems water delivery, control mechanisms and disposal systems. 


\section{ELA VIEM. Enviomental Consultants}

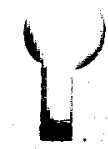

\section{ENVIRONMENTAL REPORT \\ Study Area VI}

The Geysers Geothermal Field

Prepared under sub-contract to Geonomics, Inc. as part of Phase Zero of the ERDA grant "Alternative Agribusiness and Industrial Uses for Exhaust Heat from Geothermal Waste Fluid, Lake County, California".

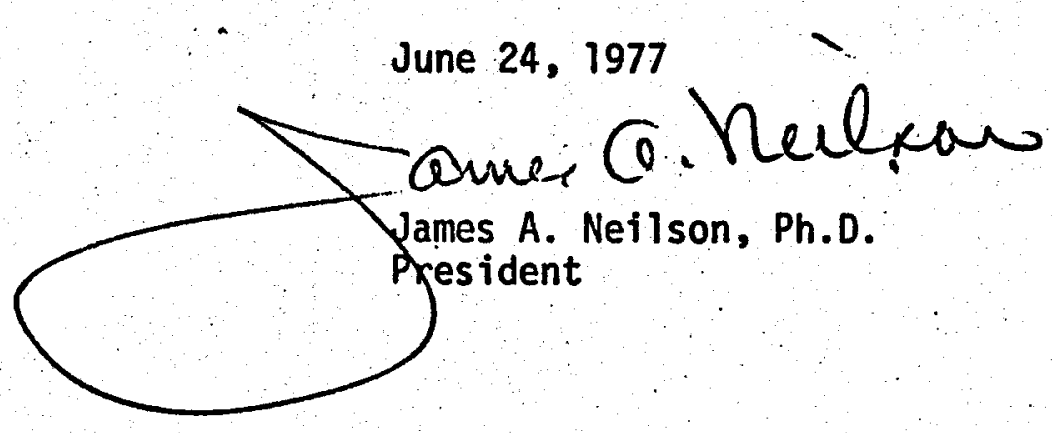




\section{u

I. STUDY AREA VI GENERAL ASPECTS 1

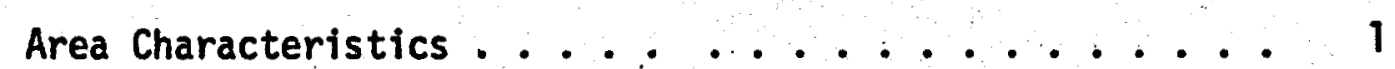
Resource Status ........................ 3

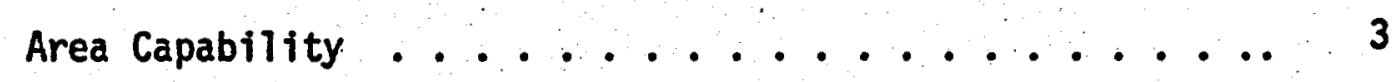

II. THE AIR RESOURCE - STATUS \& QUALITY 5

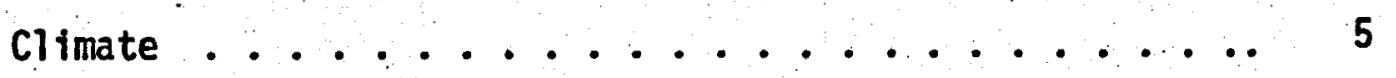
Air Quality . . . . . . . . . . . . . . 7 Effects of Non-Electrical Development ......... 10

1II. THE WATER RESOURCE - STATUS \& QUALITY 10

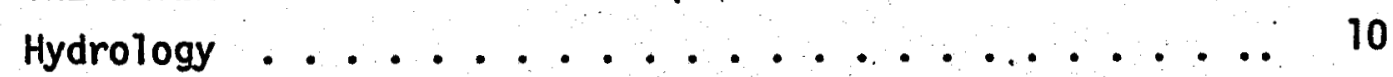
Water Quality ..................... 11 Effects of Non-Electrical Development ....... 18

IV. THE VEGETATION RESOURCE 18 Plant Communities .................. 22 Rare \& Endangered Species . ............ 45 Effects of Non-Electrical Development ........ 46

V. THE FAUNAL RESOURCE 46 


\section{ELD VIEM. Emiromental Consultants}

\section{LIST OF TABLES}

TABLE 1 AVERAGE MONTHLY \& SEASONAL PRECIPITATION ...... 5

TABLE 2 TEMPERATURE MEANS \& EXTREME ............ 6

TABLE 3 HEATING DEGREE DAYS ............ 6

TABLE 4 MEAN WIND DIRECTION AND SPEED .......... 8

TABLE 5 NON-CONDENSIBLE GASES AND SOLIDS ENTRAINED IN STEAM 9

TABLE 6 HYDROGEN SULFIDE MONITORING SUMMARY ........ 9

TABLE 7 MEAN WATER FLOWS OF BIG SULPHUR CREEK ....... 11

TABLE 8 SURFACE WATER \& ANALYSIS OF BIG SULPHUR CREEK ABOVE

THRU 11 GEYSERS POWER PLANT ....................... 12-15

TABLE 12 WATER QUALITY CHARACTERISTICS FOR BIG SULPHUR, SQUAW, LITTLE SULPHUR AND PIETA CREEKS ......... 16-17

TABLE 13 ZONAL, TRANSZONAL, AZONAL PLANT COMMUNITIES ... 19

TABLE 14 SPECIES IN GRASSLANDS $\ldots \ldots . \ldots \ldots$

\section{LIST OF FIGURES}

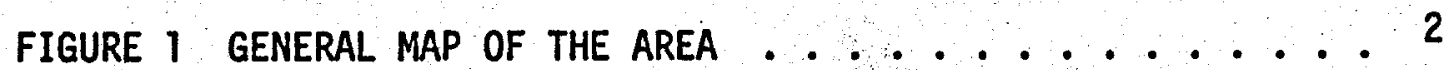

FIGURE 2 EVAPOTRANSPIRATION CURVE ...........4 4 


\section{Environmental Consultants}

INTRODUCTION

Study Area VI is the site of the original steam discovery well in 1924. The first electrical generating plant, P.G. \& E. Units 1 and 2 of $60 \mathrm{MW}$ capacity, was completed in 1961. The field now is the - largest geothermal production field in the world, generating $502 \mathrm{MW}$. No non-electrical uses are currently being applied in the field.

The environmental analysis that follows is based largely upon ECOVIEW's own work in the field beginning in 1972; but supplementary information derived from federal and state agencies, and from Union 011 Company's and P.G. \& E.'s research studies done over the same period has been used.

\section{STUDY AREA VI GENERAL ASPECTS}

\section{Area Characteristics}

The Geysers geothermal field is centered along the Big Sulphur Creek Drainage System mostly in the upper reaches of Big Sulphur and Squaw Creeks. The study area comprises about 16 square miles, but field exploration covers a total area up to five times that. Figure 1 shows general terrain features, the location of most wells, and power plants. It is a mountainous area with steep slopes, many of which are unstable from depths of 50 to 200 feet. Landslides are common, elevations range from 1600 in Big Sulphur Creek to 3600 feet at the western base of Cobb Mountain. Soils are generally rocky and thin. Vegetation is largely brushland; but many woodlands, grasslands, savannahs, and forest areas exist. A few scattered residences are present along the river; but the region as a whole is open space with the geothermal development superimposed. 
$E$

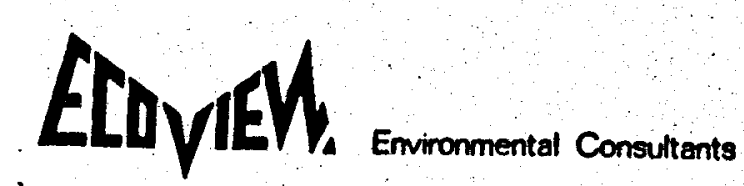

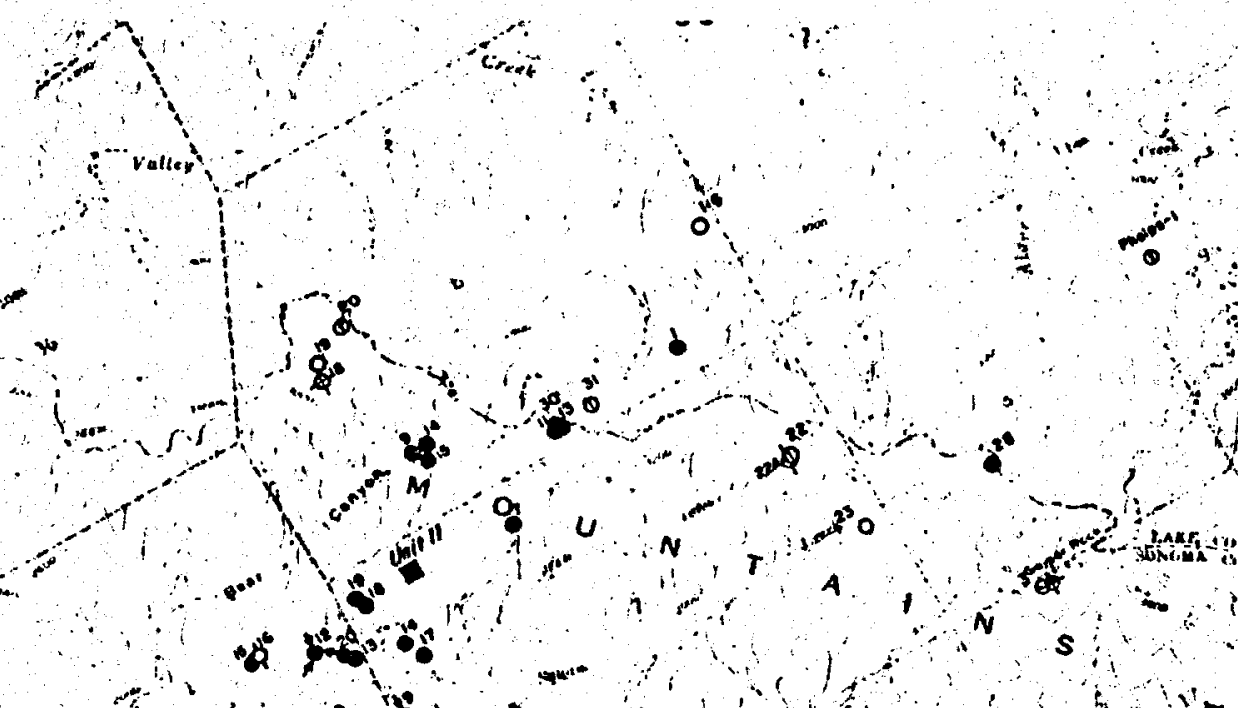

$$
\begin{array}{r}
3 \\
4 \\
4
\end{array}
$$

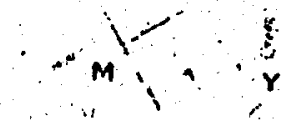

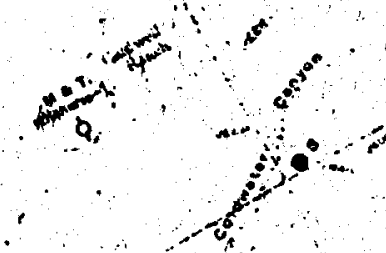
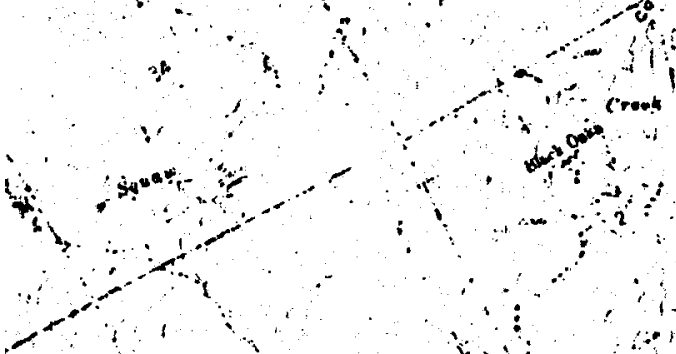

$a_{1}$<smiles>[Si]1[Si][Si][Si]1</smiles>
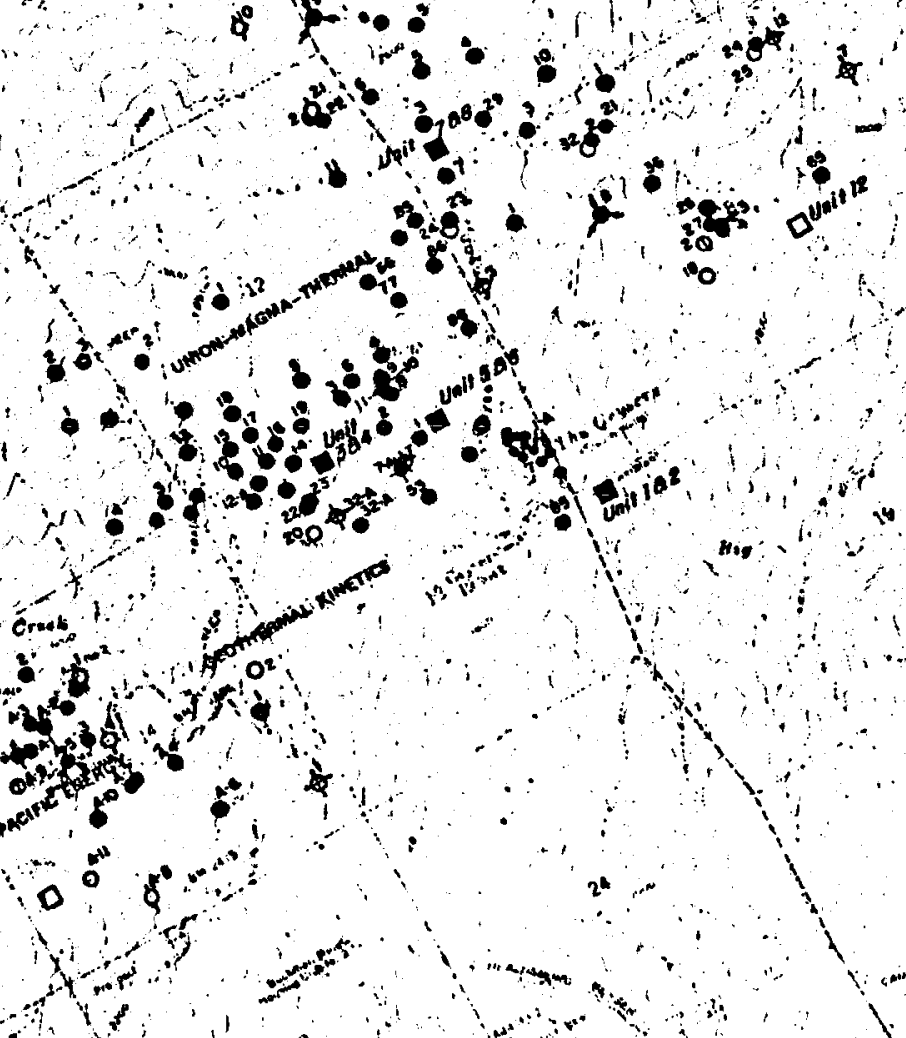

Figure 1. General Map of the Area

IGURe 1. The current, pro-

ducing Geysers fleld. ore producing welle; o are wells not yet operational; 1 yre producing power plants; 0 are की is
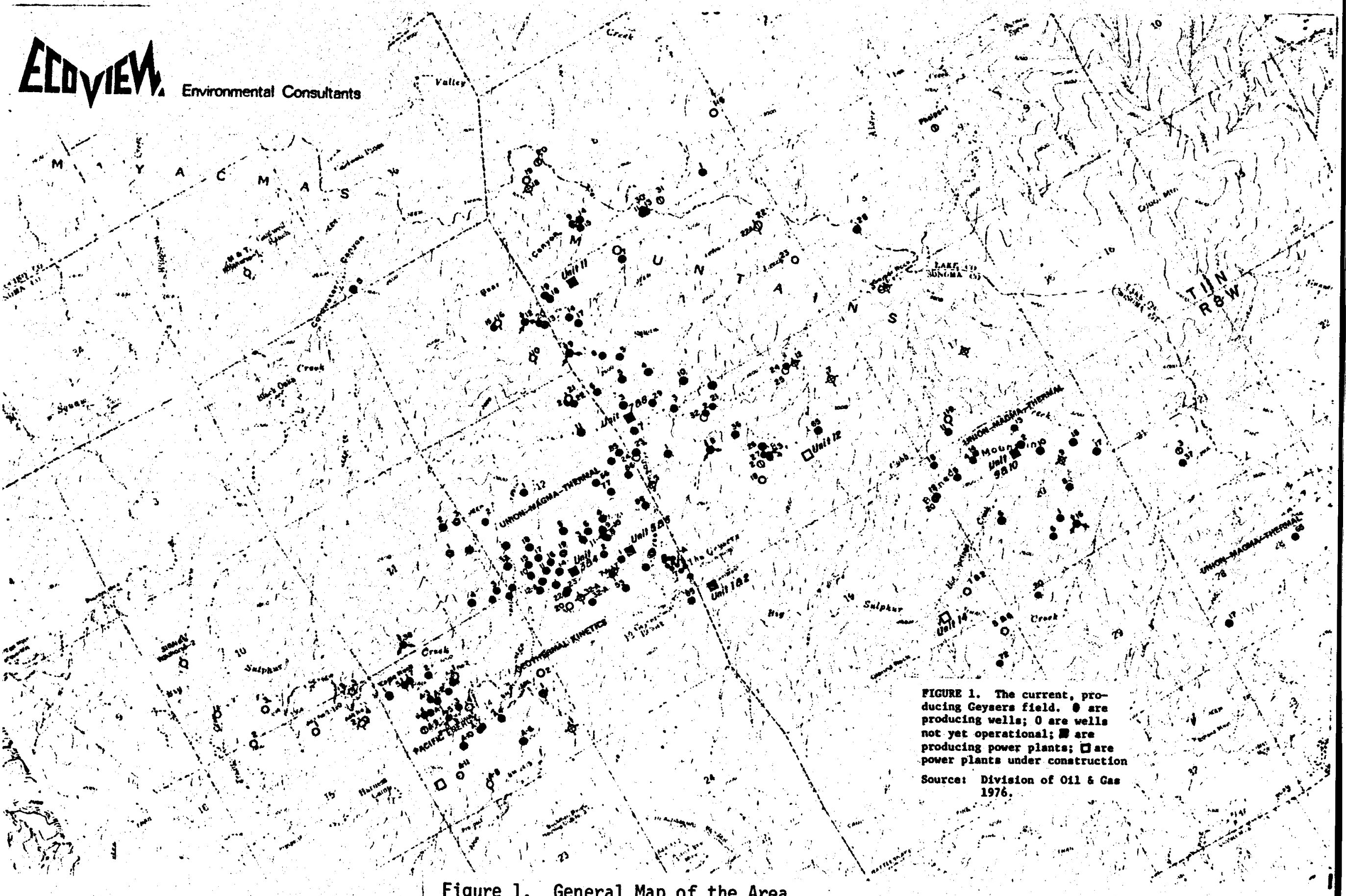


\section{Environmental Consultants}

Because the terrain is so rough, the opportunity for non-electrical uses will be largely limited to abandoned drill pads which support one or two wells unproductive for electrical development. Access to the area is afforded by three routes: The Geysers - Healdsburg Road through Jimtown; the Geysers - Cloverdale Road along Big Sulphur Creek; and a private road from Cobb Mountain to Geysers Rock to join the main service road connecting the various power plants. The latter road is not paved nor is it improved along its whole route, al though work is progressing at this time. The Geysers - Healdsburg is suitable for heavy loads; but it is narrow and winding and, hence, relatively slow. The Geysers - Cloverdale Road is very narrow and winding over most of its length. It is suttable for light traffic only.

\section{The Resource Status}

At present there are over 125 wells drilled at the Geysers and 11 power plants in operation, 4 more are in various stages of construction, and 5 more are planned. The resource is largely dry steam.

Condensate waters might be used; but limited space and plant design make such applications difficult. The most likely resource is steam from spent wells. Union 0il, Thermogenics (formerly Pacific Energy), and Aminoil (formerly Burmah 0i1 - Signal 0i1) are the principal developers.

\section{Area Capability}

Within the restrictions of space, the area will afford a considerable source of energy for many years even if electrical generation becomes obsolete.

For most areas, available space will be limited to well pads which average $200^{\prime} \times 250^{\prime}$ for single well pads - somewhat larger for multi- 


\section{CAv M. Environmental Consultants}

L

U figure 2. Evapotranspiration Curve

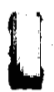

The theoretical relationship of temperature

$1]$ and water regime based on Thornthwalte's method of 'calculating evapotranspiration' (Thornthwaite, Mather and Carter, 1957). The upper graph compares precipitation with estimated evapotranspiration (Insufficient temperature data is available from The Geysers area to construct the curre), and shows the critical points in relation to plant water usage. The graphs below approximate the periods and relative intensities of host and organism growth during the year.
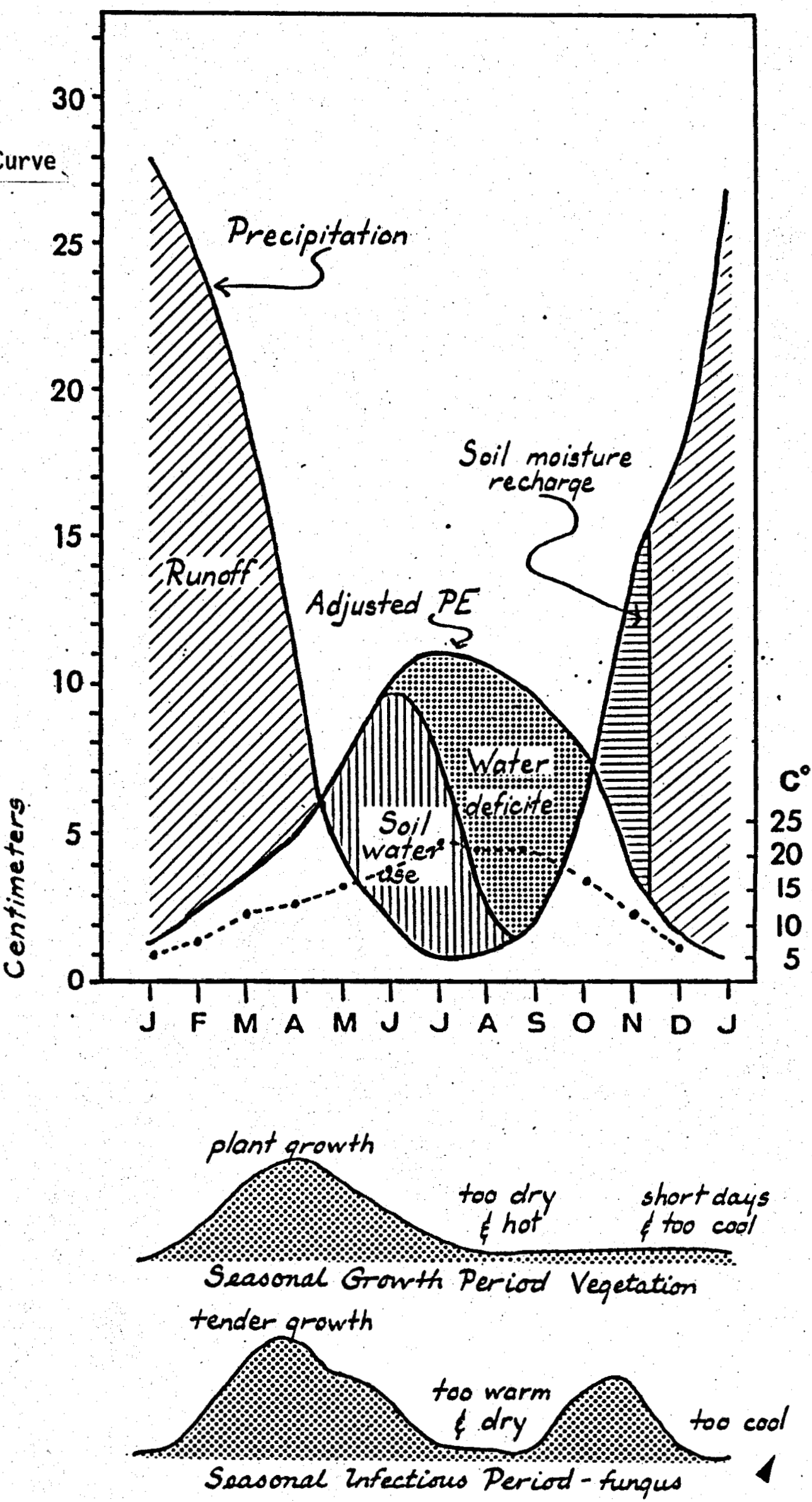


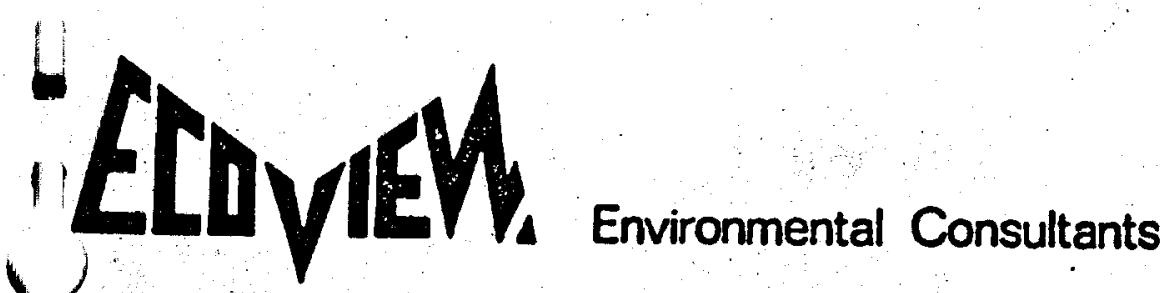

well pads. Hence, non-electric uses will be restricted to high temperature processing resulting in high value products transported by truck to Bay Area outlets and distribution points.

\section{THE AIR RESOURCE - STATUS AND QUALITY}

\section{Climate}

The climate of the Geysers region is characterized by wet winters and dry summers. Temperatures have a relatively wide range, highs occasionally exceed $100^{\circ} \mathrm{F}$ and lows sometimes fall several degrees below $32^{\circ} \mathrm{F}$. The surmer dry period lasts long enough so that stored soil moisture is depleted by vegetation and grasses and herbs wither (Figure 2).

Approximately $95 \%$ of the annual average precipitation of 55 inches occurs during the period of October through April (Table 1). The rainy season is characterized by periods of stormy weather alternating with periods of fair weather. The heaviest and most prolonged periods of rainfall are associated with storms that approach the California Coast from a southwesterly direction. More than $80 \%$ of the precipitation is associated with winds from a southerly direction. Seasonal rainfall averages tend to increase with elevation and also increase northward. The maximum and minimum rainfali in the vicinity of the Geysers is 100 inches and 30 inches.

TABLE 1

AVERAGE MONTHLY \& SEASONAL PRECIPITATION THE GEYSERS (INCHES)

JAN. FEB. MAR. APR. MAY JUNE JULY AUG, SEPT. OCT. NOV. DEC YEAR

$\begin{array}{llllllllllllllll}11.48 & 10.34 & 7.21 & 4.50 & 1.76 & .62 & .02 & .23 & .66 & 2.89 & 5.96 & 9.20 & 55.37\end{array}$

SOURCE: U. S. Weather Bureau 


\section{Environmental Consultants}

The annual mean temperature is $60^{\circ} \mathrm{F}$ (Table 2). The normai daily minimum temperature during the winter months is near $40^{\circ} \mathrm{F}$., but temperatures below freezing are not uncommon. Temperatures generally rise to the mid-forties in the early afternoon during the coldest months of the year. The summer normal daily temperature is 85 to $90^{\circ} \mathrm{F}$. and the normal daily minimum is about $52^{\circ} \mathrm{F}$. On the average, (plus five to six times per year) the daytime maximums may rise to $100^{\circ} \mathrm{F}$. Table 3 shows the number of heating degree days for the Cloverdale Geysers Area, this is a measure of the heat demand during the year.

\section{TABLE 2 \\ IEMPERATURE MEAUIS \& EXTREMES \\ CLOVERDALE 3 SSE $(0 \mathrm{~F})$}

JAN, FEB, MAR, APR, MAY JUNE JULY AUG, SEPT, OCT, NOV, DEC, YEAR

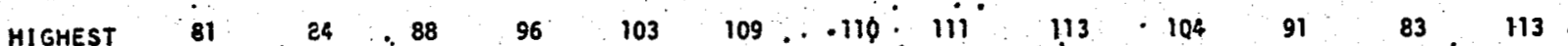
$\begin{array}{lllllllllllllllll}\text { MEAN MAX } & 57.2 & 61.5 & 66.5 & 72.3 & 78.9 & 86.2 & 92.2 & 91.6 & 88.8 & 78.4 & 67.5 & 58.4 & 75.0\end{array}$ $\begin{array}{lllllllllllllll}\text { MEAN } & 47.2 & 50.5 & 54.1 & 58.3 & 63.5 & 69.4 & 72.9 & 71.7 & 70.3 & 63.3 & 55.0 & 48.7 & 60.4\end{array}$

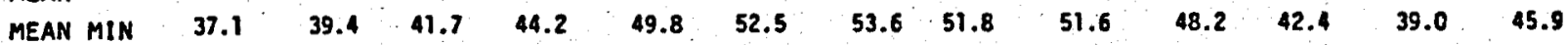
LOWEST $\quad \begin{array}{llllllllllllll} & 20 & 25 & 28 & 29 & 35 & 39 & 10 & 37 & 39 & 28 & 26 & 19 & 19\end{array}$

SOURCE: U. S. Weather Bureau

TABLE 3

HEATING DEGREE DAYS (DASE $65^{\circ}$ F)

CLOVERDALE 3SSE

JAN. FEB. MAR, APR, MAY JUNE JULY AUG, SEPT, OCT, NOV, DEC, YEAR

$\begin{array}{lllllllllllllllllll}551.8 & 406 & 337.9 & 201 & 46.5 & 0 & 0 & 0 & 0 & 52.7 & 300 & 505.3 & 2401.2\end{array}$

Heating Degree Days equals the number of degrees below $65^{\circ} \mathrm{F}$ the dally average temperature reaches during given season.

Computed according to the formula: $\left(65^{\circ} \mathrm{F}\right.$ - Monthly mean temp.) $\times$ (number of days in month)

The degree day provides a measure of the heat demand for specific periods in the Cloverdale-Geysers area. 


\section{Environmental Consultants}

The prevailing wind flow above the Geysers area is from the west or northwest during most of the year (Table 4); however, local wind direction is strongly influenced by terrain features. Wind speeds near ground level are normally less than five miles per hour in the early morning hours, but frequently reach 20 miles per hour during summer afternoons. During the wet winter season, wind speeds in excess of 20 miles per hour may occur from a southerly direction. During this season, winds greater than 20 miles per hour are normally associated with precipitation.

During the wet season, November through March, the relative humidity averages about 75 to $80 \%$ during the night and about $70 \%$ during the day. The relative humidity is quite low during the remainder of the year with night time averages of 40 to $50 \%$ and daytime averages of about $30 \%$.

Atmospheric inversions are frequently observed in Big Sulphur Creek Valley during early to mid-morning on fair weather days. These inversions appear to occur at elevations lower than the surrounding ridgelines. The valley inversions generally break up before noon with the presences of westerly winds.

Air Quality

Since geothermal power production began at the Geysers in the late 1950's ambient air quality has steadily declined due to pollutants entrained in geothermal steam. Entrained pollutants include the particulates and non-conclusive gases listed in Table 5. Hydrogen sulfide emissions have increased to a level resulting in area-wide violations of the California ambient air quality standard of 30 parts per billion (ppb) averaged over a period of one hour. The statistics presented in Table 6are generally representative of the data available on hydrogen sulfide pollution at the Geysers. Source tests indicate that no 


\section{ECD VIEW. Emmomental Consultants}

TABLE 4

CLOVERDALE PEAK: MEAN WIND DIRECTION AND MEAN WIND SPEED NOVEMBER 1, 1972 - OCTOBER 31, 1974

FREQUENCY DISTRIBUTION

Mean Wind

Direction

CALM

NNE

NE

ENE

$\mathbf{E}$

ESE

SE

$\because$ SSE

$\mathbf{S}$

SSW

SW

WSW

W

WNW

NW

NNW

N

Annual average

Mean Wind Speed (mph)

0-3 4-7 8-12 13-18 $19-24$ 25-50 51-65 65 Total Aver Speed

$14 \quad 0 \quad 0 \quad 0$

00

0

$0 \quad 14$

0.0

$133 \quad 446 \quad 62 \quad-5$

$0 \quad 0 \quad 0$

$0646 \cdot 5.1$

$\begin{array}{llll}114 & 335 & 72 & 12\end{array}$

10

0

0 534 . 5.5

$\begin{array}{llll}65 & 302 & 122 & 14\end{array}$

$\begin{array}{llll}54 & 396 & 218 & 29\end{array}$

$0 \quad 0$

0

$0 \quad 505$

6.5

20

0

$0 \quad 700$

7.1

$\begin{array}{llll}37 & 82 & 36 & 9\end{array}$

00

0

0. 164

6.3

$\begin{array}{llll}75 & 111 & 62 & 14\end{array}$

$0 \quad 0$

0

$0 \quad 262.6 .0$

$85 \quad 229,125 \quad: 74$.

12

$0 \quad \because \quad 0$

$0 \quad 525 \quad 7.6$

$\begin{array}{llllll}86 & 359 & 373 & 287 & 148 & 97\end{array}$

0

$0 \quad 1350$

12.0

$50 \quad 36$

0

o 753 .

11.0

246

0

o 1015

8.2

$1 \quad 1$

0

o 730

6.0 $\begin{array}{llll}135 & 434 & 136 & 23\end{array}$

$0 \quad 0$

0

0.626

4.9 $167 \quad 133 \quad 22$

$0 \quad 0$

0

$0 \quad 322$

3.9

$\begin{array}{llll}191 & 388 & 61 & 6\end{array}$

$\begin{array}{llll}92 & 405 & 233 & 24\end{array}$

$\begin{array}{lllll}188 & 1297 & 1411 \quad 228\end{array}$

$\begin{array}{ll}0 & 0 \\ 0 & 0 \\ 7 & 0\end{array}$

0

$0 \quad 646$

4.9

$0 \quad 0 \quad 754$

o $\quad 0 \quad 3132$

6.6

8.0 7.6

* Reprinted from Mooney, 1975. 


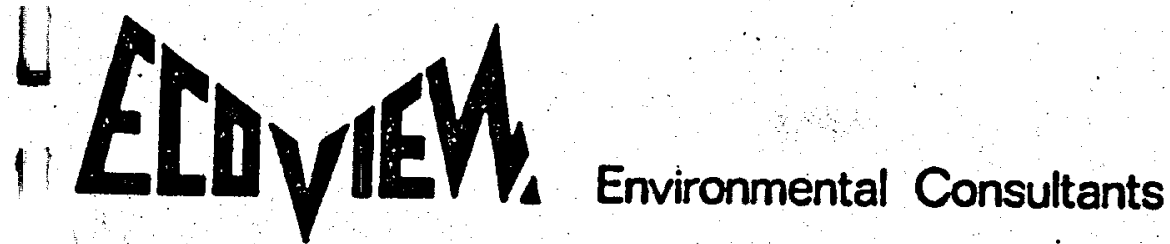

significant regional air pollution has resulted from emissions of gases and particulates other than from hydrogen sulfide to date.

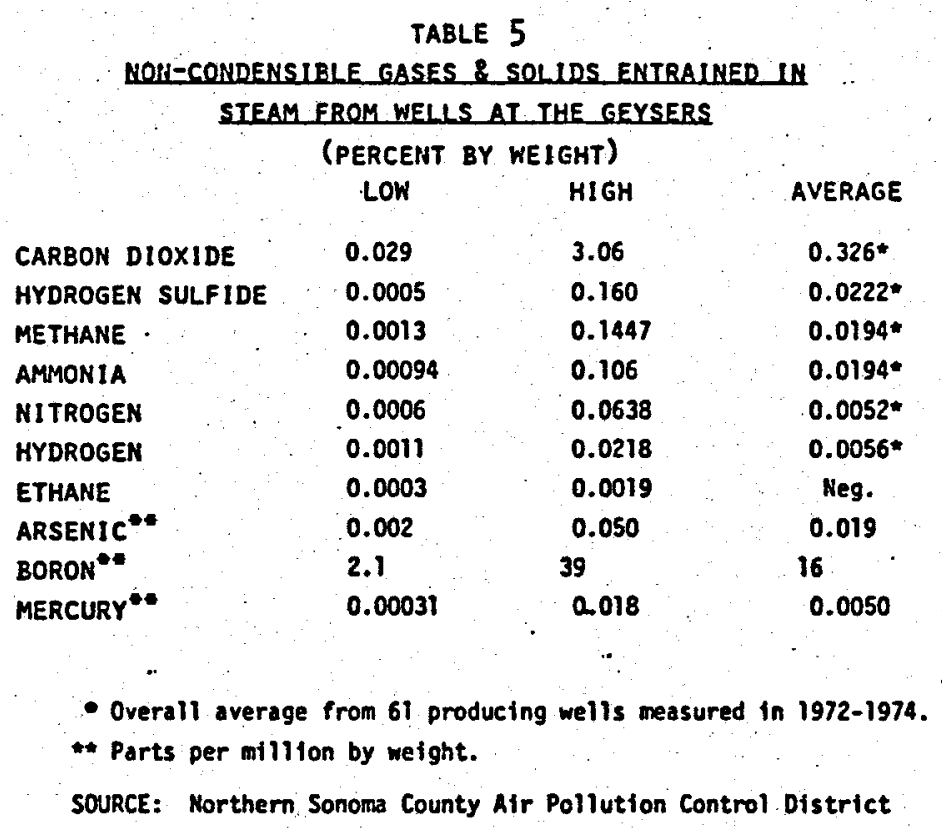

- TABLE 6

HYDROGEN SULFIDE MONITORING SUMMARY

No. of Sampling

Highest Measured

Range of Overall

Concentration Locations*

Average $\mathrm{ppb} \mathrm{H}_{2} \mathrm{~S}$

$\mathrm{ppb} \mathrm{H}_{2} \mathrm{~S}$

Range in \% of Measurements Greater than $30 \mathrm{ppb}$
37
$2-116$
626
$0-70$

FROM: Altschuler Report, Hydrogen Sulfide Air Quality Study, The Geysers, 1970 - 1975. P.G. \& E. 
Environmental Consultants

\section{The Effects of Non-Electrical Development}

Air quality maintenance at the Geysers during non-electric operations is a critical aspect to the economic viability of many applications. Hydrogen sulfide must be scrubbed before off-gases are released to the atmosphere. There are many methods of scrubbing $\mathrm{H}_{2} \mathrm{~S}$, but the cost and the low percentage of gas to the volume of steam are problems that have plaqued the electrical power generation clean-up for a decade. Unless the process involves the use of $\mathrm{H}_{2} \mathrm{~S}$, as for instance a bleaching agent or an enzyme inhibitor, its presence is a liability. In any event, a completely closed system would tend to keep much of the gas in solution and permit reinjection to deep levels in the field. Nevertheless, some non-condensible gases must be dealt with in the use of even low quality steam. Other gases that accompany steam at the Geysers will pose no problems, even if they are exhausted directly.

\section{THE WATER RESOURCES - STATUS AND QUALITY}

Hydrology

There are five major drainages within the Geysers area. Big Sulphur Creek comprises the largest $\left(82.3 \mathrm{mi}^{2}\right)$ and receives run-off from 37 tributaries, only eight of which tend to flow year round. Little Sulphur Creek has 14 tributaries of which all but six flow throughout the year and drains an area of about 14 square miles. The remaining drainages include Frazier Creek (with 6 tributaries), the North Branch of Little Sulphur Creek (with 11 tributaries), and Squaw Creek (with 14 tributaries).

With 55 inches of average annual precipitation in the Big Sulphur Creek drainage, about 30.1 inches of run-off is produced on the average. The mean annual and monthly discharge from Big Sulphur Creek is present- 


\section{$141 / 1 /$ Environmental Consultants}

ed in Table 7. The average discharge for 13 years of record is about 146.0 acre-feet per year. The maximum recorded discharge is 15,000 cts. and the minimum is 1.8 cts. measured at the USGS gaging station near Cloverdale.

\section{TABLE 7}

BLE SULPHUR CREEK NEAR CLOVERDALE

GEAN ELOWS IN ACRE - FEET

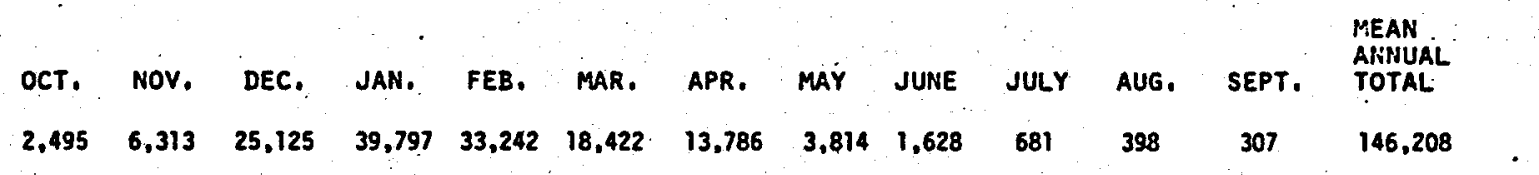

SOURCE: $\quad$ U.5.6.5.

Water Quality

Surface water in the drainage is bicarbonate in type with calcium and magnesium the predominant cations. Highly mineralized water flows into Big Sulphur Creek from fumaroles, hot springs, and steam vents in the Geysers area. Water quality in Big Sulphur Creek changes significantly over various portions of its reaches. Water quality analysis for points along Big. Sulphur Creek, Squaw Creek and Little Sulphur Creek are presented in Tables 8 through 12. Of the water quality, parameters studied, mercury, ammonia, and water temperature appear to be significant relative to aquatic life in the Geysers area. The high boron content $(0.1$ to $6.4 \mathrm{mg} / \mathrm{p})$ makes the water unsuitable for irrigation of many crops. 


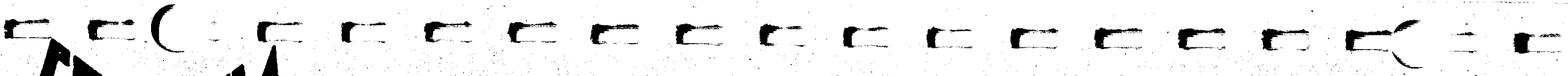

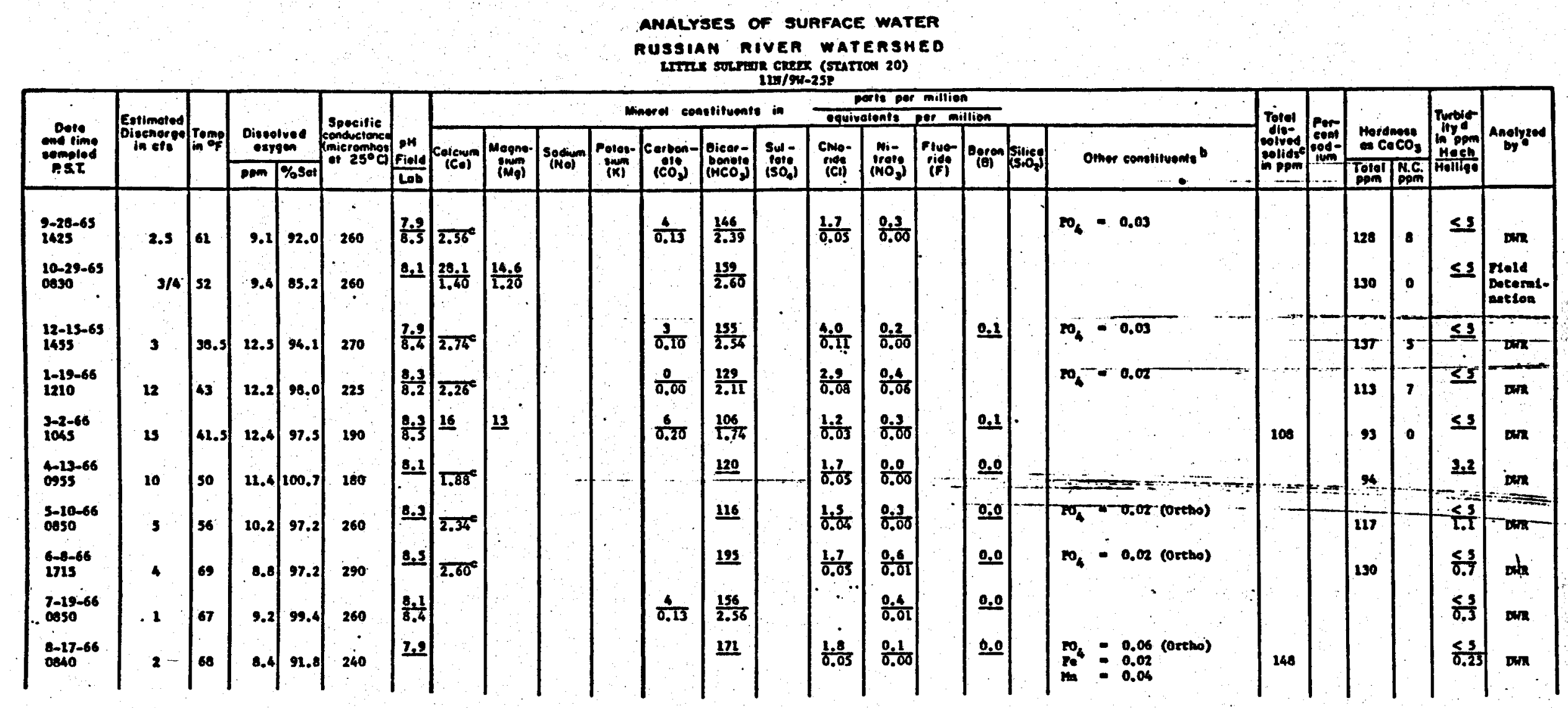

- Sum of calcium end meanasium in epm

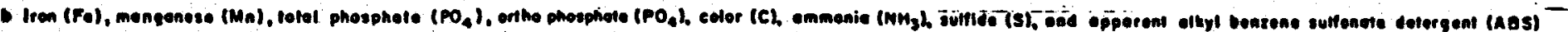
- Grovimotric determinetlon.

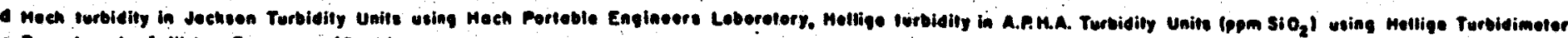

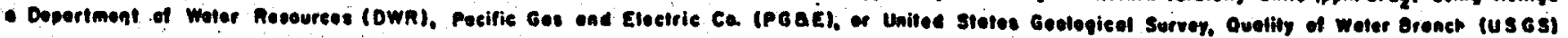




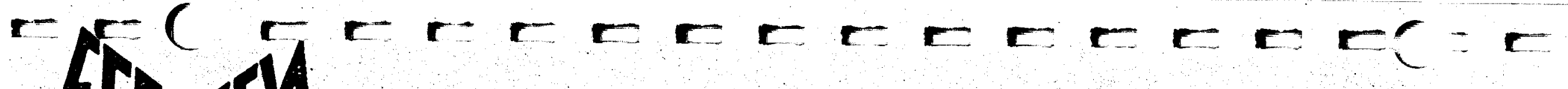

Environmental Consultants a anacrses of surface water

TABLE 11

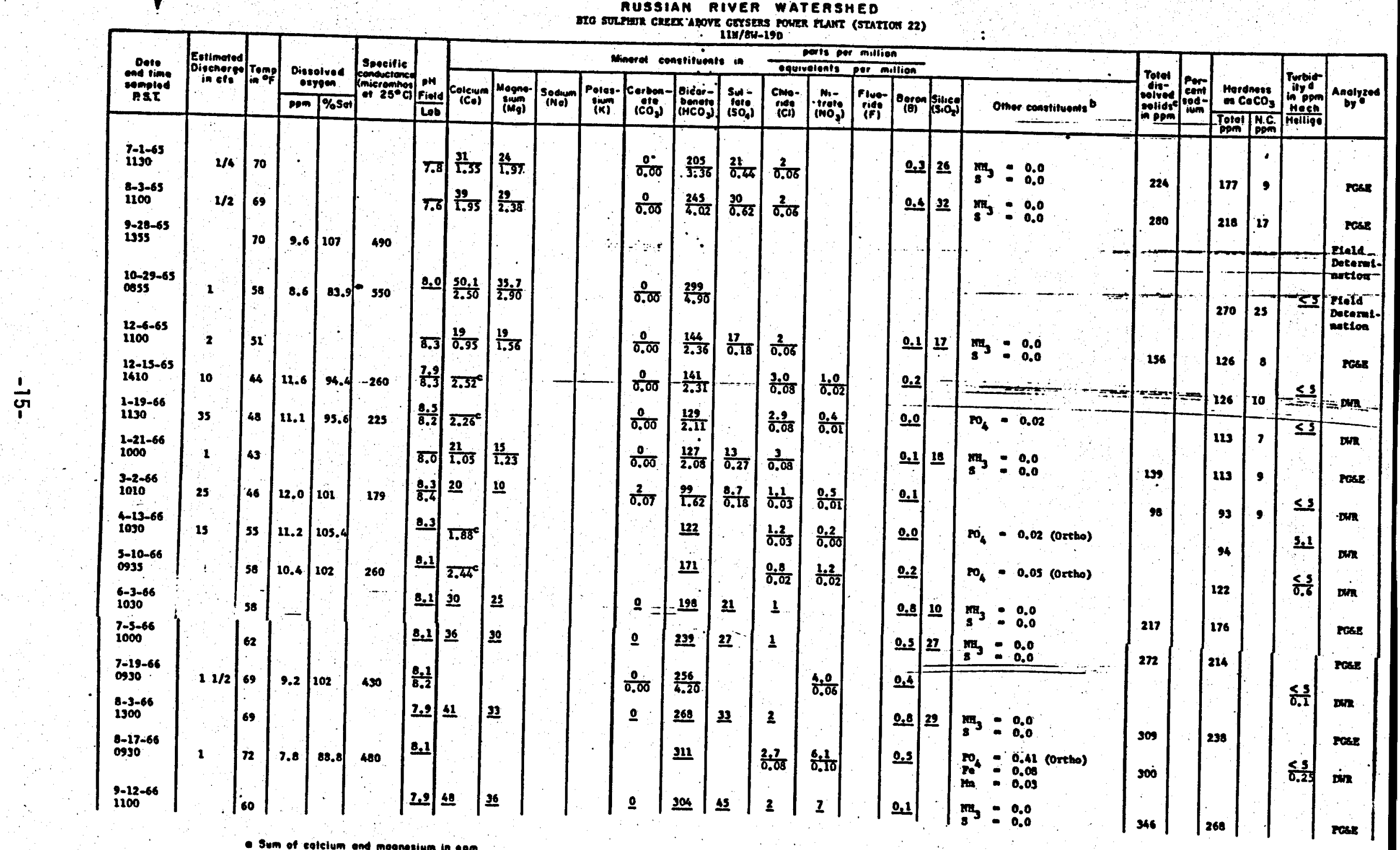

- Sum of ealeium un mognosium in opm

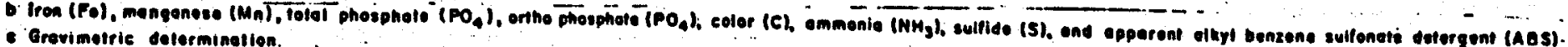

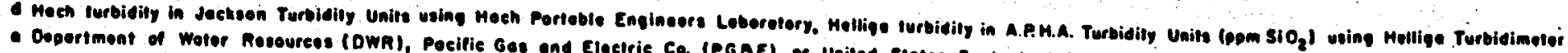

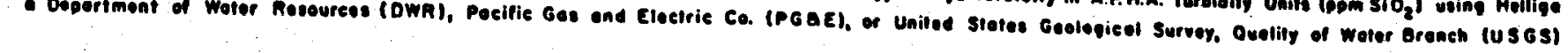




\section{Environmental Consultants}

Sedimentation caused by run-off from dirt roads and well pads in the area is a problem during winter and spring rainfall periods.

The Effects of Non-Electric Development

Water quality maintenance requirements will make it impossible to discharge steam condensate into surface steams. This means that condensates must either be injected to deep levels, much as they are in the electrical generation cycle, or processed to remove boron, arsenic, and heavy metals to a level acceptable to the Northern California Water Quality Control Board. Disposal of solid or liquid wastes resulting from any non-electrical process will have to be carefully controlled. Precautions must be taken to prevent spillage or an accidental discharge of soluable materials or the leachwater resulting from them that may impair water quality or biological activity in streams and underground aquafers.

\section{THE VEGETATION RESOURCE}

The following discussion, (taken from EIR's for Union, Pacific Energy, Burmah 0i1, Geothermal Kinetics, and California Geothermal) segregates plant communities into landscape units. These community units are grouped into zonal, transzonal, and azonal types (see Table 13) as defined by Langhenheim (1962) and Neilson (1973).

Zonal communities reflect the broad character of a landscape unit; they represent $c 1$ imax, subclimax, and successional stages that have developed primarily under the influence of regional and local climate. In the Big Sulphur drainage, including all its tributaries, four landscape units are presented: (1) flood plain, (2) foothill, ridge-canyon, and (4) mountain. Ridge-canyon is dominant, but elements of the foothill division appear in the western portion. The mountain division is represented on Cobb Mountain to the east; the flood plain division is represented weakly in the lowest reaches of drainage. In the foothill division, grasslands and oak savannahs predominate; in 


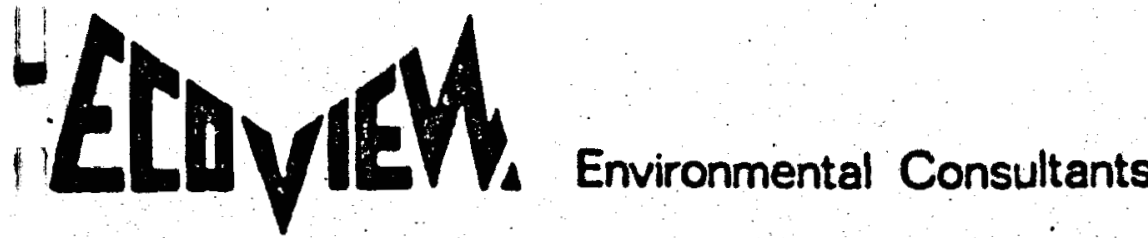

b

Table XI-6. Plent comminity types and assoclat1ons grouped according to their zone and dominant physlognomic character.

(Comanities in the vicinity but not on the leasebold are marked

by an asterisk.)

zONAL

TRALSZONAI

AZORAL

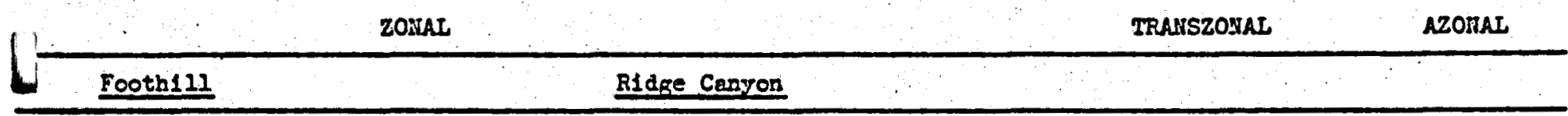

\section{Ulforata grass-herb}

Early succesalonal herb-prass associatlons Rock Barrens

Serpentine Rock Barrens*
Rock-Face Stream-s1de Association
Pond

Ruderel

Hot Springs

Springs

Introduced annuel grassland (Gr)

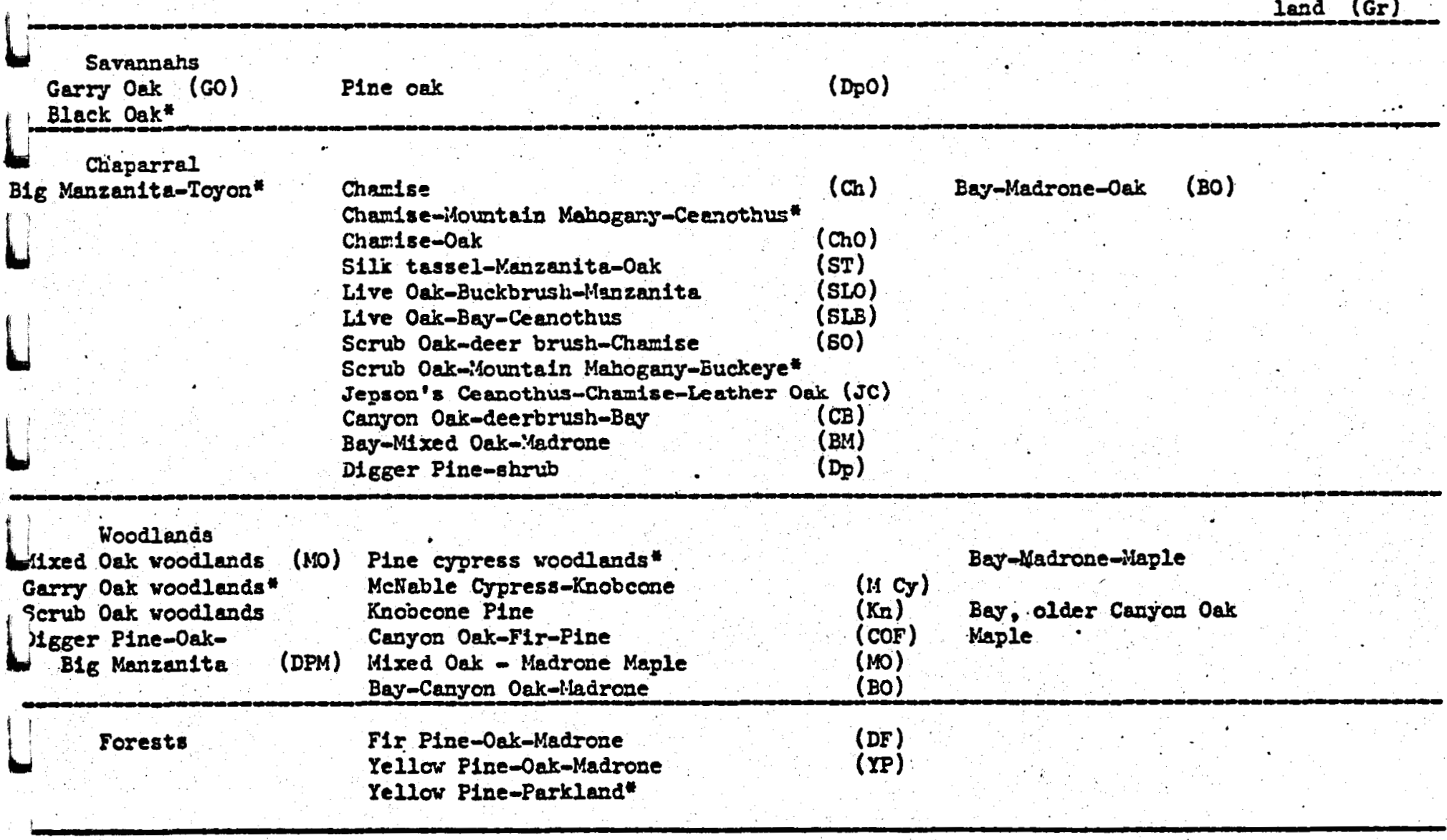




\section{ADVMV Environmental Consultants}

the ridge-canyon division, chaparral and oak-fir-pine woodlands predominate. Altitude, exposure, and edaphic quality modify these zonal types to produce an intricate vegetation pattern over the landscape. The area's climate is very much influenced by Cobb Mountain. Also, serpentine parent materials has caused the most distinctive edaphic variant in the area.

Azonal communities exhibit nearly uniform characteristics, regardless of the landscape unit in which they are found. These communities are primarily ponds, ruderal, and man-disturbed or man-manipulated areas, such as introduced annual grassland.

Transzonal communities result from intense modifications of zonal factors; these modifications dramatically affect zonal characteristics and usually act across one or more landscape units. A riparian conmunity series with its associated ecotonal community is such an example. Azonal communities usually form a continuum of community composition, especially when moving across several altitudinal levels. Because both azonal and transzonal community types are so dominantly influenced by water stress or soil moisture conditions (though not always), they are distinguished by radical departures in composition, form and appearance from zonal communities.

The basic community types and their principal subdivisions (associations or facies) in the Geysers areas are as follows:

\section{Zonal \\ -- Grassiands \\ - Savannahs \\ -- Chaparral}

(a) chamise

(b) shrub interior live oak - manzanita - jimbrush 


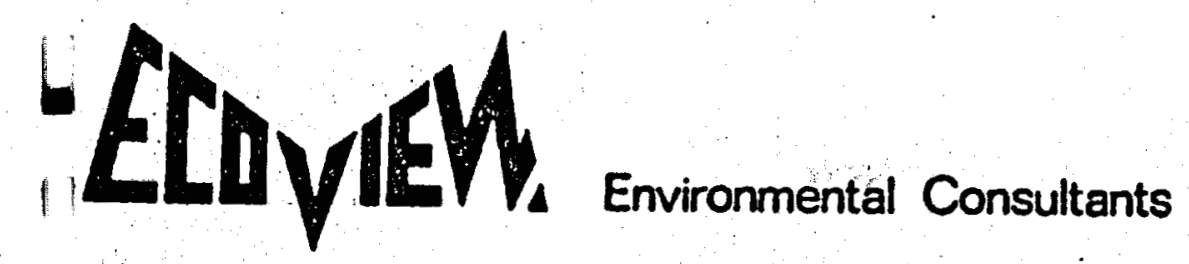

1

(c) shrub interior live oak - manzanita - ceanothus - bay

(d) shrub interior live oak - bay - madrone

(e) toyon - mountain mahogany - garrya

- Forest Communities

(a) Garry oak woodland

(b) black oak woodland

(c) mixed oak woodland

(d) canyon oak - bay - maple - madrone

(e) Digger pine

-- Pine - Fir - Oak Woodlands

(a) Digger pine - mountain mahogany - lupine

(b) Digger pine - manzanita - live oak

(c) ponderosa pine - black oak - garry oak

(d) Douglas fir - black oak - bay

Azonal

-- Ponds and Seep Areas

- Ruderal or Weedy Areas

- Introduced Annual Grassland

Transzona 1

-- Riparian

(a) stream course

(b) rock cliffs

(c) spring

The brief descriptions that follow will serve to characterize the area's major plant communities. In Appendix 1, each species recorded for the area is related to that community in which it occurs most commoniy. Also noted is an indication of its relative abundance. 
Plant Communities

Grasslands

The grasslands that occur may be transitional to chaparral, maintained as pre-climax in areas where trees cannot grow, or are the understory of savannahs. All such grasslands are comprised of the same species with a few notable exceptions.

Originally, the area's grasslands and savannahs were composed of the native California grass-herb community which consisted largely of ephemeral annuals and perennial herbs. While dominants varied widely. and the floristic array was large, these can be more or less characterized by existing remnants, such as blue field gilia (Gilia capitata), tri-colored gilia (Gilia tricolor), annual fescues (Festuca sp.), . : . -purple needle and thread grass (Stipa pulchra), popcorn flower. (Plagiobothrys nothofulvas), blue lupines (Lupinus bicolor, L. nana, L. pachylobus), yellow owls clover (Orthocarpus attenuatus), and several clovers (Trifolium obtusaflorum, I. dichotomum, I. fucatum). In moist draws, the buttercups (Ranunculus California and R. occidentalis), and shooting star (Dodecatheon hendersonii) are common.

With overgrazing, the azonal community, termed the California introduced annual grassland, has superseded the California grass-herb in most places. While, many members of the original flora have survived many other foreign species have been introduced, (Table 14). Those starred in Table 14 are acknowledged indicators of poor range condition. 


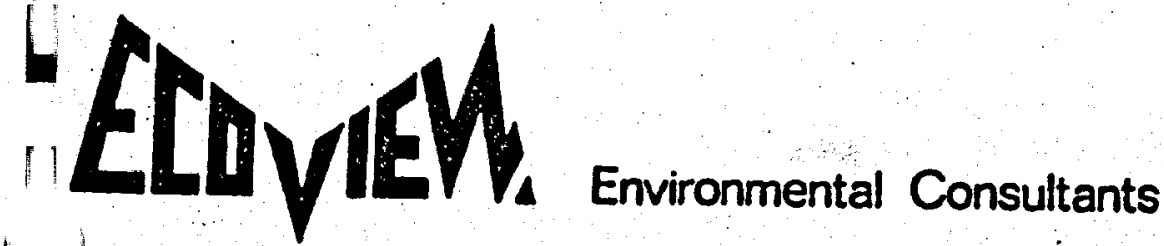

Table 14. Grasses and herb species found in grasslands sequentially arranged from high to low relative abundance.

\begin{tabular}{|c|c|}
\hline *Dog-tail grass & *Tar weed \\
\hline *Ripgut & Filagrees \\
\hline Slender wild oat & *Star thistle \\
\hline Soft chess & Buttercups \\
\hline *Medusa head & Torilis nodosa \\
\hline *Annual hairgrass & Little barley \\
\hline Malpias fescue & Linanthus \\
\hline Plantago hookeriana & Alsike clover \\
\hline *Nit grass & Notched-leaf clover \\
\hline Owls clover & Tom-cat clover \\
\hline California lotus & Vetch \\
\hline Shooting star & Gum weed \\
\hline Bed straw & California fescue \\
\hline & Clarkia \\
\hline
\end{tabular}

Wet meadows exist in localized situations; they tend to be associated with seeps and swales in grassiands. Indicator species include any of the following:

California oatgrass

Sweet vernal grass

Thread \& needlegrass

Kentucky bluegrass

Ta11 fescue

Bent grass

Meadow barley

Common brome
Danthonia californica

Anthxanthum odorata

Stipa cernua

Poa pratensis

Festuca arundinacea

Agrostis scabra

Hordeum brachyantherum

Bromus vulgaris 


\section{Environmental Consultants}

Kellogg's yampah (Perideridia kelloggii), brodiaea (Brodiea congesta or B. elegans) and several sedges and rushes are also in this association.

California Prairie is very weakly represented in the Geysers area. The indicator species are the thread and needlegrasses: Stipa puchra and s. lepida.

Savannah

Savannahs are grassland communities that contain scattered trees covering up to $15 \%$ of ground surface. While the grassiand is dominant, the namie of the savannah is taken from the tree layer. The associated grassland communities are most often the California annual grassland or the native herb-grass community described earlier. Several grasses appear in savannahs in association with the trees. These are California melic (Melica californica), Torrey's melic (Melica torreyana), thread and needlegrass (Stipa cernua).

The mixed savannah has a preponderance of blue oak (Quercus douglasii) with occasional specimens of Garry oak (Q. garryana) on east-facing slopes. The understory is largely introduced annual grass land or native mixed herb types. Big manzanita (Arctostaphylos manzanita), elderberry (Sambucus mexicana), and poison oak (Rhus diversiloba) are scattered occasionally under the oaks, especially near rock outcrops. The presence of Garry oak and canyon oak (Q. chrysolepis) causes this community to appear as a transitional type from the blue oak savannah dominant at lower elevations to the Garry oak savannah dominant at higher elevations.

Blue oak savannahs are found at lower elevations on dry, hot slopes. The understory is largely introduced annual grassland. Garry oak savannahs occur at higher elevation normally on western and southern slopes. Black oak savannahs occur just below the ridge crests on north and west facing slopes. It should be noted that savannahs and grasslands fre- 
Environmental Consultants

quently occupy areas subject to extensive landsliding and mass wastage.

A few, small open stands of valley oak (Q. lobata) have been mapped in the Geysers area. However, valley oak is not common above the flood plain zone. It prefers deep, rich, moist soils and becomes more abundant west of the Squaw Creek confluence.

In some areas, Digger pines (Pinus sabiniana) form a savannah. This type is related to the Digger Pine-Shrub type; but because of deeper soils, the shrub layer is limited to big manzanita and poison oak. The understory is mostly introduced annual grassland.

\section{Chaparrat}

Chaparrals or brushlands of the Geysers area can be divided into two groups: (a) interior or hard chaparrals and (b) montane or soft chaparra1. The pattern of shrub vegetation in the Geysers area presents a mosaic of several well defined communities and integradations of a variety of others in which species dominance varies greatly according to exposure, soil type, fire history, and water relations. Due to the dense canopy, very few herbs are present. The hard chaparral types commonly found are listed in order of decreasing xeric (dry) habitats are:
a. chamise
b. chamise - mahogany - ceanothus - manzanita
c. chamise - shrubby oak - manzanita
d. chamise - leather oak - Jepsons ceanothus - Stanford's manzanita
e. shrubby oak - silk tasse1 - manzanita
f. shrubby oak - manzanita - ceanothus
g. manzanita 
Montane chaparrals are:
a. ceanothus - chamise - manzanita - madrone
b. shrubby oak - mahogany - buckeye
c. coffeeberry - shrubby oak - ceanothus
d. shrubby oak - deerbrush chamise
e. shrubby oak - bay - ceanothus
f. shrubby canyon oak - deerbrush - bay
g. bay - mixed oak - madrone
h. toyon - mahogany - silk tassel

Chamise chaparral occurs on south and western exposures where radiation. is most intense; $i$. e. on upper canyon slopes and ridge tops. It often grades into the following community. It is subject to recurrent intense fire varying from 5 to 25 year periods. Soils are invariably very thin and poor, usually of graywacke parent material: In older stands, there is a little infiltration of other species. Its composition is as follows:
chamise: $\quad 90 \%$
$5 \%$
(Adenostema fasciculatum)
Buckbrush:
Yerba santa: $\quad 1 \%$
(Ceanothus cerneatus)
(Eriodictyon californica)

Because chamise produces a growth inhibitory toxin, few other plants exist in dense stands. The few associates that do occur are:
Soap plant
(Chlorogalum pomeridianuum)
Death camas
(Zygadenus venosum or $z$. fremontii)
Brome grass
(Bromus rubens or $\underline{B}$. tectorum)
Monkey flower
(Mimulus douglassii) 
The chamise - ceanothus - manzanita - mahogany community occurs on south, west, and east exposures of upper canyon slopes where soil is about 1 to 2 feet deep, usually developed from graywacke parent material. It is also subject to intense recurrent fires that burn 5 to 25 years apart depending upon density and fire load. 01d unburned stands begin to show senescence and a preponderance of dead wood with very little leaf cover and new growth in stands over 25 years old. It may reach a height of 12 feet. They often become infiltrated with Digger pine. Composition is variable from place to. place but the dominant and subdominants include:
chamise
10 to $30 \%$
(Adenostema facisculatum)
ceanothus
5 to $25 \%$
(Ceanothus cuneatus)
manzanita
5 to $30 \%$
(Arctostaphios glandulosa, A. stanfordii,
mahogany
3 to $10 \%$
(Cercocarpus betuloides)
A. viscida)
oaks
5 to $15 \%$
(Quercus wislizenii ssp. frutescens,
Q. chrysolepis, Q. dumosa)

Herbs include those of the chamise community and also the following:
California fescue
(Festuca californica)
squirrel-tail grass
(Sitanion hystrix)
gold. wire
(Hypericum concinnum)
bull thistle
(Circium vulare)
California windmill flower(Silene californicum)

The chamise - shrubby oak - manzanita community is probably only a common variation of the former, but represents a significant change in dominance. It occurs in dense stands with over $100 \%$ cover on deeper, wetter soils. The change in dominance is: 


\section{HAla Environmental Consultants}

$\begin{array}{ll}\text { chamise } & 10 \text { to } 15 \% \\ \text { shrubby oaks } & 50 \text { to } 75 \% \\ \text { manzanita } & 20 \text { to } 50 \%\end{array}$

The chamise - leather oak - Jepson's ceanothus - Stanford's manzanita community is quite distinct being associated with serpentine soils of the Henneke \& Huse series. Herbaceous associates are also distinct. Dominance varies between the two series, but the dominance and subdominants for the Henneke series are:

\begin{tabular}{|c|c|c|}
\hline chamise & 0 to $30 \%$ & \\
\hline leather oak & 10 to $30 \%$ & (Quercus durata) \\
\hline Jepson's ceanothus & 10 to $40 \%$ & (Ceanothus jepsonii) \\
\hline Stanford's manzanita & 5 to $50 \%$ & (Arctostaphplos) \\
\hline cypress & 0 to $20 \%$ & (Cupressus sargentii and/or \\
\hline knobcone pine & 0 to $10 \%$ & $\begin{array}{c}\text { c. McNabbiana) } \\
\text { (Pinus attenuata) }\end{array}$ \\
\hline
\end{tabular}

On the Huse series, dominance most often shifts to leather oak, Jepson's ceanothus, cypress, and Stanford's manzanita.

On Henneke soils the herbaceous understory may include:

$\begin{array}{ll}\begin{array}{l}\text { Greene's groundse } \\ \text { squirrel-tail grass }\end{array} & \frac{\text { (Senicio greenij) }}{\text { (Sitanion hystrix) }} \\ \text { blue grass } & \underline{\text { (Poa scabrella) }} \\ \text { serpentine reedgrass } & \text { (Agrostis ophitidus) } \\ \text { wall flower } & \text { (Erysimum capitatum) } \\ \text { serpentine jewel flower } & \text { (Streptanthus barbiger) }\end{array}$




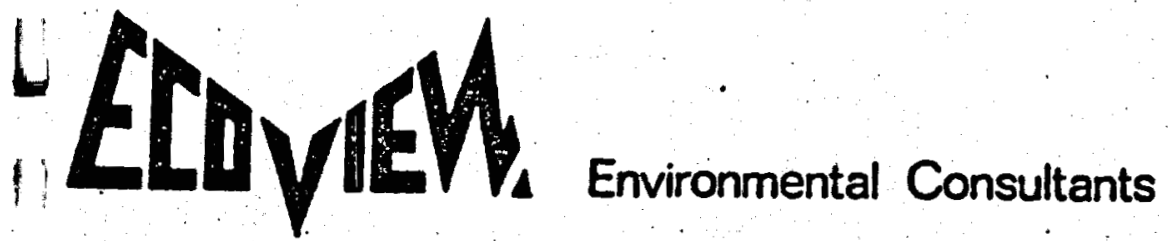

On Huse soils the following are sparsely represented:

$\begin{array}{ll}\text { Indian warrior } & \text { (Pedicularis densiflora) } \\ \text { Iris } & \text { (Iris macrosiphon) } \\ \text { Common woodrush } & \text { (Luzula subsessilis) } \\ \text { Granite gilia } & \text { (Leptodactylon pungeus ssp. pulchriflorum) }\end{array}$

The shrubby oak - silk tassel - manzanita comnunit is associated with wind ridges along the crest of the Mayacmas on chert and greenstone parent material. Its distribution is quite 1 imited. It forms a very dense community with no understory. The dominants and subdominants are:

\begin{tabular}{|c|c|c|}
\hline shrubby oak & $50 \%$ & $\begin{array}{l}\text { (Quercus wislizenif ssp. frutescens, } \\
\text { Q. chrysolepis - shrubby form) }\end{array}$ \\
\hline & $30 \%$ & (Garrya eliptica) \\
\hline & $20 \%$ & (Arctostaphylos glandulosa, A. stanfordii) \\
\hline
\end{tabular}

The shrubby oak - manzanita - ceanothus community is widespread and may be generically related to several of the montane chaparrals. It tends to be on east, north, and west exposures. Usually it forms very dense stands and cover values are over 100\%. The dominance values are:

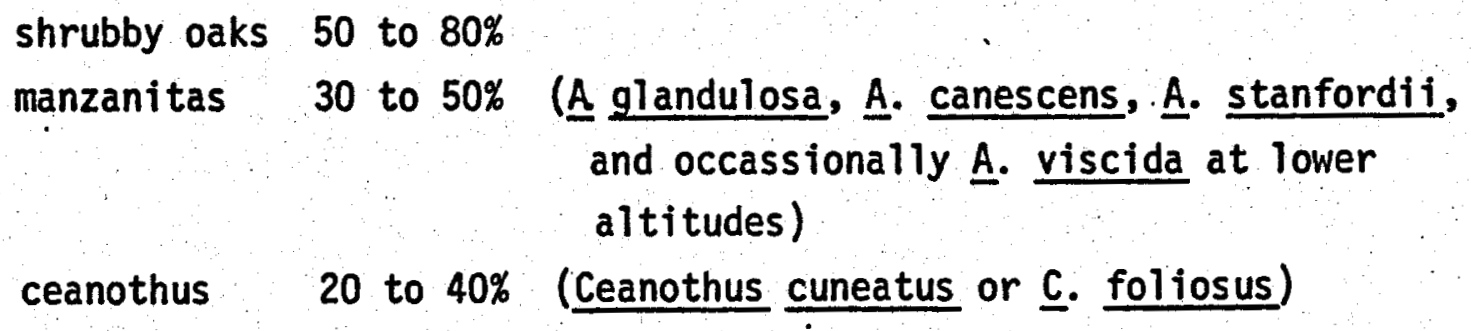

The manzanita community is common at lower altitudes of the foothill zone - cover is quite variable (20 to $90 \%)$ and usually has understory. It is often monotypic. : However, the general composition is: 
Environmental Consultants

$\begin{array}{ll}\text { big manzanita } & 20 \text { to } 100 \% \text { (Arctostaphylos manzanita) } \\ \text { buckbrush } & 5 \text { to } 15 \% \text { (Ceanothus cuneatus) } \\ \text { toyon } & 0 \text { to } 5 \% \text { (Heteromeles arbutifolia) } \\ \text { poison oak } & 0 \text { to } 5 \% \text { (Rhus diversiloba) } \\ \text { live oak } & 0 \text { to } 5 \% \text { (Quercus chrysolepis or } Q \text {. wislizenii } \\ \text { SSp. frutescens) }\end{array}$

Other shrubs are also found in varying amounts in many stands of hard chaparral. These include:

chaparral pea (Pickeringia montana), often on ridge tops deerbrush (Lotus scoparius)

bush rock spiraea (Holodiscus boursieri) usually on rock outcrops oak-leafed gooseberry (Ribes quercetorum)

northern monkey flower (Mimulus aurantiacus), rock outcrops chaparral clematis (Clematis lasiandra)

chaparral poppy (Dendromecon rigida) purple nightshade (Solanum xantii)

red bud (Circus occidentalis)

Montane chaparrals are made up largely of non-burl formers that do not root sprout readily. Most species are easily killed by moderately intense fires. They are less resistant to drought than hard chaparral, but are none-the-less capable of withstanding drought. Most of these communities are low seral successional stages of oak woodlands or Douglas fir forests, except that fire usually prevents them from . reaching climax seres.

In the ceanothus - chamise - manzanita - madrone community, the introduction of the madrone and usually a little bay indicate its mesic nature. Chamise, as always, occupies the thinnest soils and driest sites. Dominance ranges from: 
Environmental Consultants

\begin{tabular}{|c|c|c|}
\hline ceanothus & 20 to $30 \%$ & (Ceanothus cuneatus, $\underline{C}$. foliosus) \\
\hline chamise & 5 to $15 \%$ & \\
\hline manzanita & 20 to $30 \%$ & $\frac{\text { (A. glandulosa }}{\text { A. }}$ canescens) A. stanfordii, \& \\
\hline madrone & 10 to $20 \%$ & (Arbutus menzezii) \\
\hline
\end{tabular}

The shrubby oak - mahogany - buckeye community is somewhat open with a thin understory. It occurs on west, north, and east exposures. Its dominance values are:

$\begin{array}{lll}\text { shrubby oak } 30 \text { to } 70 \% & \text { (Quercus chrysolepis and/or Q. dumosa) } \\ \text { mahogany } & 10 \text { to } 50 \% & \text { (Cercocarpus betuloides) } \\ \text { buckeye } & 5 \text { to } 20 \% & \text { (Aesculus californica) }\end{array}$

The coffeeberry - shrubby oak - ceanothus community is of limited distribution, often associated with open pine stands where it forms a weak understory. It is best developed on north and east facing slopes of the ridge-canyon zone where cover often exceeds $100 \%$. The dominance values are:

\begin{tabular}{|c|c|c|}
\hline coffeeberry & 40 to $60 \%$ & (Rhamnus californica) \\
\hline canyon oak & 30 to $50 \%$ & (Quercus chrysolepis) \\
\hline ceanothus & 5 to $30 \%$ & (Ceanothus foliosus, $\underline{\text { c integerrimus }}$ \\
\hline
\end{tabular}

The shrubby oak-deerbrush-chamise community occupies steep slopes on north, east, or west exposures. It is very dense and occurs on soils of uneven depth.

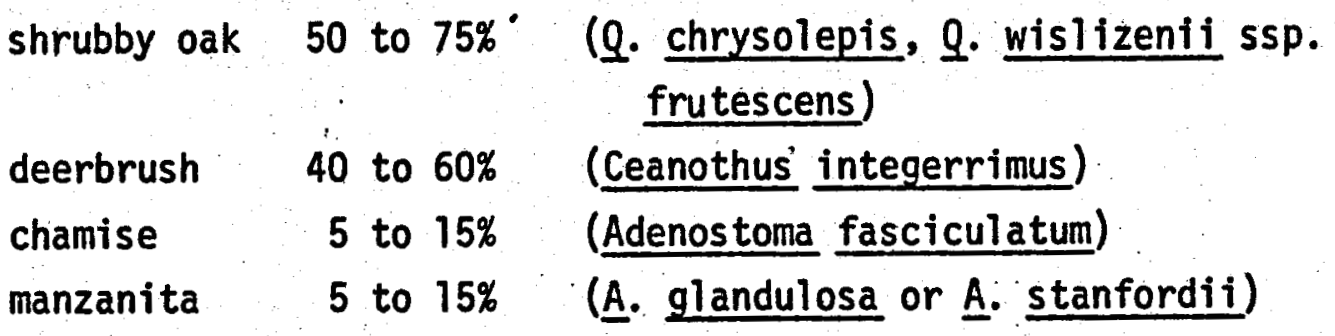




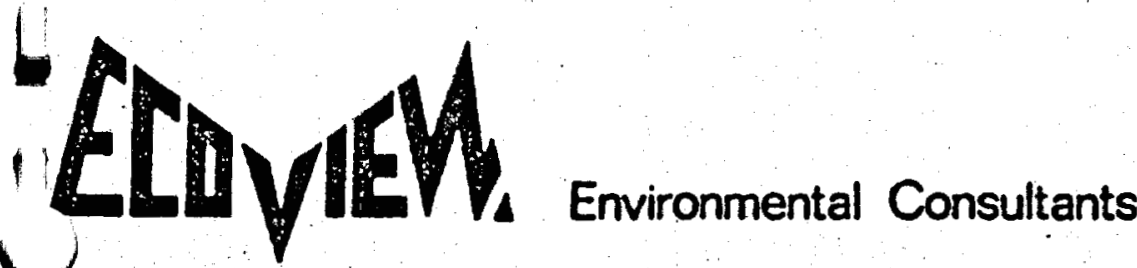

The shrubby oak - bay - ceanothus community is widespread on upper canyon slopes with north-east and west exposure or on canyon sides where soils are deep ( \pm 2 feet). It is an indicator of mesic conditions with either cool air drainages or moist soils much of the summer. It is usually associated next to xeric communities and, hence, subject to repeated burning.

\begin{tabular}{|c|c|c|}
\hline shrubby oaks & 30 to $80 \%$ & $\begin{array}{l}\text { (Q. chrysolepis and/or Q. wislizenii } \\
\text { ssp. frutescens) }\end{array}$ \\
\hline bay & 10 to $60 \%$ & (Umbellularia californica) \\
\hline ceanothus & 5 to $15 \%$ & (Ceanothus integerrimus or $\mathrm{C}$. foliosus) \\
\hline $\begin{array}{l}\text { California } \\
\text { nutmeg }\end{array}$ & 3 to $8 \%$ & (Torreya californica) \\
\hline madrone & 5 to $8 \%$ & (Arbutus menzesii) \\
\hline
\end{tabular}

The shrub interior live oak - manzanita - ceanothus - bay community occupies upper north and east slopes. It is devoid of chamise and may be mid-successional to bay - fir - oak forests. It occurs on shallow to moderately deep soils and is relatively mesic. It appears to be disturbed by occasional intense fires, apparently after long dry seasons. This community, in its oldest phases, may attain a height of 12 feet and is often extremely dense. Its general composition is:

\begin{tabular}{l|l} 
shrub interior live oak & 30 to $60 \%$ \\
ceanothus species & 5 to $15 \%$ \\
big manzanita & 5 to $8 \%$ \\
bay & 10 to $20 \%$ \\
scrub oak & 5 to $8 \%$ \\
toyon & 5 to $10 \%$ \\
poison oak & 2 to $5 \%$ \\
Digger pine & 1 to $3 \%$ \\
elderberry & $1 \% \quad$ (Sambucus mexiana)
\end{tabular}




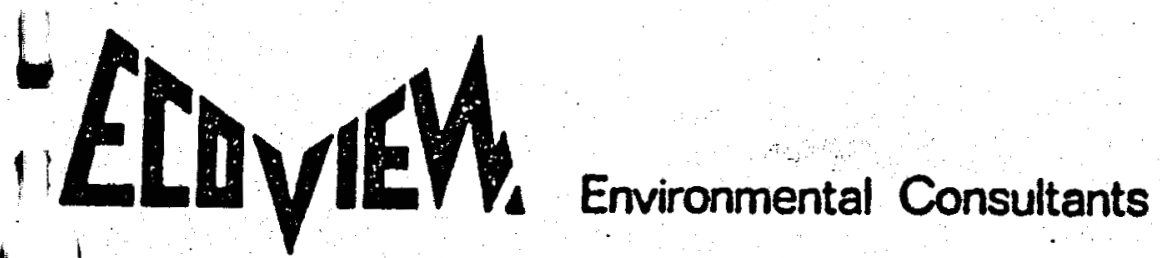

Herbs are:

$\begin{array}{ll}\text { California fescue } & 1 \% \\ \text { bed-straw } & 1 \% \\ \text { chaparral honeysuckle } & 1 \%\end{array}$

and where recent fire has created openings:

slender wild oat $\quad 20 \%$

ripgut 20\%

red brome 1 to $30 \%$

white-stem filaree 1 to $20 \%$

bull thistle 5 to $15 \%$

Napa star thistle 5 to $15 \%$

all other species $\quad 5$ to $20 \%$

The shrub interior live oak - bay - madrone community is highly variable in composition and aspect. It occurs on north, northwest, or northeast slopes. On occasion, it is predominantly live oak, and elsewhere is a mixture. Fires are infrequent. Soil is variable in depth but for the most part the community occurs on the Josephine series. It appears to be successional to the oak - maple - madrone fir forest. Some stands may attain $20^{\prime}$ in height, but the majority of stands are dense thickets of about $7^{\prime}$ to $10^{\prime}$ high. Dominant species are:

shrub interior live oak $\quad 30$ to $90 \%$

canyon oak

5 to $25 \%$

bay

5 to $25 \%$

madrone

10 to $25 \%$

black oak

0 to $5 \%$

big-leaf maple

0 to $5 \%$

Douglas fir

0 to $8 \%$

California nutmeg

0 to $1 \%$ 


\section{Environmental Consultants}

The toyon - garrya - mountain mahogany shrub community occupies very. steep canyon sides (60\% slope) at lower elevations or is confined to narrow steep draws along stream courses. Fires are rare, and it seems to be a closed association made up as follows:

$\begin{array}{ll}\text { toyon } & 25 \text { to } 75 \% \\ \text { garrya } & 25 \text { to } 60 \% \\ \text { mountain mahogany } & 10 \text { to } 50 \% \\ \text { canyon oak } & 0 \text { to } 10 \% \\ \text { black oak } & 0 \text { to } 3 \% \\ \text { coffeeberry } & 0 \text { to } 3 \%\end{array}$

Montane chaparrals have a broad array of herbaceous species. The more common species include:

\begin{tabular}{|c|c|}
\hline broad-leaved hosackia & (Lotus crassifolius) \\
\hline California fescue & (Festuca californica) \\
\hline chaparral honeysuckle & (Lonicera interrupta) \\
\hline California toothwort & (Dentaria californica var. cardiophylla) \\
\hline California milkwort & (Polyagala californica) \\
\hline California melic & (Melica californica) \\
\hline western morning glory & $\frac{\text { (Convolvulus occidental is }}{\text { var. solanens is) }}$ \\
\hline purple nightshade & (Solanum xantii) \\
\hline shooting star & (Dodecatheon hendersonii) \\
\hline lousewort & (Pedicularia densiflora) \\
\hline mountain monardella & (Mondardella odoratissima) \\
\hline chaparral Virgin's Bower & (Clematis lasiantha) \\
\hline star flower & (Trientialis latifolia) \\
\hline pitcher sage & (Lepechina calycina) (on ridge tops). \\
\hline
\end{tabular}




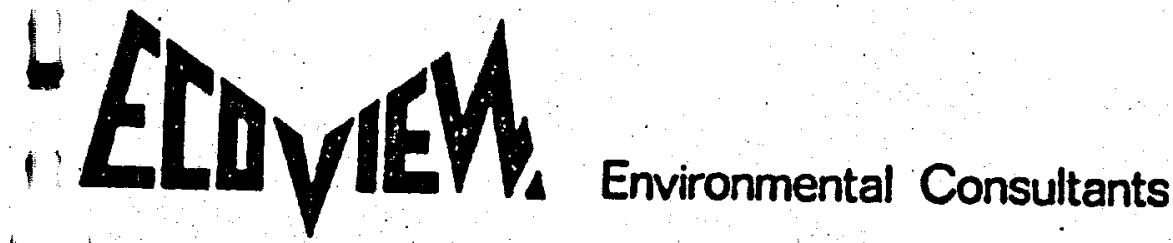

Other shrubs that occur in montane chaparrals include:

squawbush

bay gooseberry

chaparral honeysuckle

snowberry

coyote bush

bush chinquapen.
(Rhus trilobata var. guinata)

(Ribes menziessi var. leptosmum)

(Lonicera interrupta)

(Symphoricarpus rivularis)

(Baccharis pilularis), associated with wet disturbed places

(Castenopsis semperviren), local stands on Cobb Mountain

Woodlands

Woodlands constitute those communities whose dominant species are over $15^{\circ}$ and under $75^{\prime}$ high. Woodlands for the most part are associated with deep rich soils and mesic habitats. Some woodland communities are associated with riparian in the transzonal habitats group fo communities; these are noted by an asterisk in the list below. Several types of woodlands can be recognized:

\section{Conifer woodlands \\ Cypress \\ knobcone pine}

Conifer-evergreen broad-leaf

Pine-cypress

Digger pine - shrub

Digger pine - canyon oak

Canyon oak - fir - pine

Knobcone - manzanita

Evergreen broad-leaf

*Bay - madrone - oak

Mixed live oak 


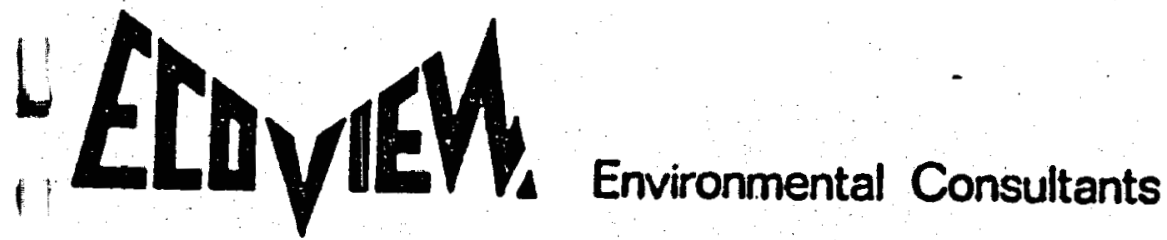

\author{
Mixed broad-leaf \\ Mixed oak \\ Live oak - bay - maple \\ *Bay - maple - alder - madrone \\ Deciduous broad-leaf \\ Black oak \\ Garry oak \\ Blue oak \\ Mixed oak \\ Scrub oak
}

This array of woodlands are mostly dominated by oaks and pines. Fire plays a very important part in the generation, maintenance, and regeneration of forest and woodlands. Fire dependent communities are the knobcone pine, the cypress, and the yellow sugar pine communities. The first two depend on fire for removal and seed germination, the third for maintenance of pure stands and development sequence.

Cypress woodlands are restricted to serpentine soils principally of the Huse series. They occur on all slopes and range from thin open stands to very dense stands. The stature rarely exceeds 68 feet; . but ranges from 5 feet to 100 feet (the latter in canyon bottoms protected from fire). Dominance values are:

$\begin{array}{llll}\text { cypress } & 60 \text { to } 100 \% & \text { (Cupressus sargentii and/or C. macnabbiana) } \\ \text { ceanothus } & 0 \text { to } 40 \% & \text { (Ceanothus } \\ \text { oak } & 0 \text { to } 15 \% & \text { (Quercus durata) } \\ \text { manzanita } & 0 \text { to } 40 \% & \text { (Arctostaphylos stanfordii) } \\ \text { pine } & 0 \text { to } 10 \% & \text { (Pinus sabinianna and/or } \underline{P} \text { attenuata) }\end{array}$

Knobcone pine woodlands are thick stands of Pinus attenuata with very little else. Their stature is from 30 to 50 feet and cover is complete. 
Pine-cypress stands are often widespread on Huse soil series. The are apparently mixtures of the two foregoing comminities. Their stature ranges from 30 to 50 feet and are very dense with usually a very high fire load. Their dominance values are:

$\begin{array}{llll}\text { pine } & 40 \text { to } 60 \% & \text { (Pinus attenuata) } \\ \text { cypress } & 40 \text { to } 60 \% & \text { (Cupressus sargentii and/or C. macnabbiana) } \\ \text { manzanita } & 10 \text { to } 30 \% & \text { (A. stanfordii) } \\ \text { ceanothus } & 5 \text { to } 20 \% & \text { (C. jepsonii) } \\ \text { oak } & 0 \text { to } 10 \% & \text { (Q. } \text { durata) }\end{array}$

Stands at the little Geysers on geothermally altered soil include hoary manzanita (A. canescens).

Knobcone - manzanita woodlands are found scattered throughout the upper Big Sulphur. Creek drainages, and are most widespread on east-facing slopes. A typical example is found just south of the Little Geysers. Associated trees are knobcone pine, black oak (Quercus kelloggi), madrone (Arbutus menzesii), sometimes canyon oak, and rarely western yellow pine (Pinus ponderosa).

The shrub understory consists of Stanford's, Eastwood's, white-leaved and hoary manzanitas, wavy-leaved ceanothus, occasionally squaw carpet (Ceanothus prostratus var. occidentale), chinquapin (Castanopsis sempervirens), California coffeeberry ( $R$. ssp. tomentosa). The herb understory consists of a sparse, intermittent cover of bracken fern (Pteridia aquilinum), paintbrush (Castilleja foliolosa), bedstraw (Galium californicum), and yellow wood violet (Viola lobata). The endemic, St. Helen!s lupine (Lupinus sericatus), appears occasionally.

Digger pine stands are of two types, apparently depending upon exposure and soil types. The Digger pine - shrub community on deep soil 


\section{Environmental Consultants}

and southeast exposures consists of Digger pine, mountain mahogany, bush lupine, and an occasional shrubby canyon oak. California fescue, coyote mint, buckwheat, and a few annual grasses form a sparse, herbaceous element in the predominantly bush lupine understory. On very thin soils or exposed rocky ridges, the Digger pine - oak community consists of Digger pine, scattered shrubs of interior live oak and Eastwoods or big manzanita, with scattered plants of squirrel-tail grass, woolly sunflower, goldprint fern, red brome, and coyote mint. Often the latter community will grade into the mixed shrub chaparral, while the former grades into mesic forest or riparian comunities.

The canyon oak - fir - pine association is transitional to the Douglas fir climax forest and appears to be an advanced successional stage of the former. Stand surveys have nearly the same presence list, but a decided shift in dominance. Nuttall's dogwood (Cornus nuttallii) is frequently common on northern and eastern slopes. The only specimens (4) of incense cedar found on the upper Big Sulphur Creek occur in this association.

of the evergreen broad-leaf woodlands, the bay - canyon oak - madrone community is found on east-facing slopes, often econtonal to riparian areas. The dominant is California bay. Canyon oak and madrone are constant associates. The maple and black oak are occasional. Young Douglas fir (Psuedotsuga menziesii) are common. Understory plants include: Western hound's tongue (Cynoglossum occidentale), red larkspur (Delphinium nudicaule), common lomatium (Lomatium utriculatum), and California milkwort (Polygala californica).

Mixed Live Oak communities become common as one proceeds westward down the Big Sulphur. They are variable in composition and cover values range from 75 to 125\%. The dominants are Coast Live Oak (Quercus agrifolia) and canyon oak (Q. chirsolepis), occasionally bay (Umbrellularia californica) and madrone (Arbutus menzesii) share a sub-dominant role. This community is usually at lower elevations associated with inter- 


\section{$b$

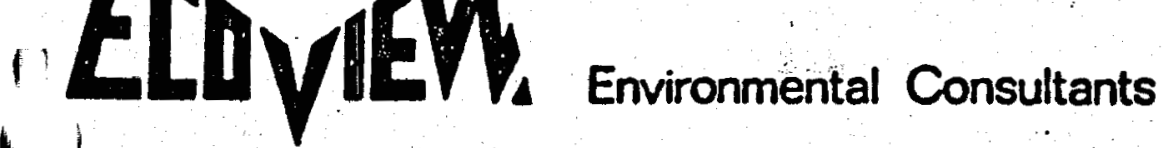

mittant water courses that are dry most of the year. At high elevations, it may form the principal zonal community.

The mixed broad-leaf communities are mixtures between the evergreen and deciderous broad-leaf communities. Their occurrence is often enough and their appearance distinct enough to be identified separately. Mixed oak - madrone - maple is found in lower canyon draws and drier east-facing slopes. Canyon oak, Garry oak and black oak grow in a variety of compositions. Madrone and maple (Acer macrophyllum) are present in most cases. Arboreal cover usually exceeds $60 \%$. Understory is largely herbaceous and consists of bur chervil (Anthriscus scandicina), miner's lettuce, western sword fern (Polystichum munitum), California polypody (Polypodium Californicum), sweet cicely (0zmorhiza chilensis).

Canyon oak - bay - maple - madrone forests are found on middle (north and east exposures) and lower slopes (on west exposures) that are relatively undisturbed by fire. This community is best developed in draws or cold air drainages on north slopes. Overstory cover approaches 90\% and only a few herbs grow under the trees. Black oak and Douglas fir are common components but at a variable density, depending upon the stage of succession.

The deciduous broad-leaf communities form distinctive woodlands on deep well drained soils. Garry oak woodland is found on drier upland sites on northwest-facing slopes. Associates are Digger pine, scrub oak, and big manzanita at a combined cover percent totalling less than $20 \%$. Trees rarely exceed $50^{\prime}$ in height.

Black oak woodland is found on upland sites on north-facing slopes, usually near pine stands, and often grading out into black oak savannahs. Cover values read $95 \%$ and trees are up to $75^{\circ}$ in height. 
Mixed oak woodland communities are variable in composition, but are predominantly black oak, canyon oak, Digger pine, madrone, buckeye, and western yellow pine. Garry oak occurs on the driest, best drained sites; bay occurs on the most mesic sites. The shrub understory is predominantly big manzanita and poison oak, but usually occurs in patches. California fescue, California melic, and perennial bromes attain their greatest abundance in this community. The degree of herbaceous understory development is dependent upon the percent overstory cover and exposure - a high percent of tree or shrub cover and/or steep cold north slopes restrict herbs composition and density. The community is found on northwest, north and east-facing slopes.

Blue oak woodlands are found on south and west exposures at lower elevations. They are indicators of intrusion of foothill zone vegetation into the ridge-canyon zone. Soils are thin and relatively poor. Occasionally big manzanita, poison oak, elderberry and buckeye occur in low numbers. The herbaceous understory is either introduced annual grasstand or native herb-grass communities; however, these are usually. pooriy developed in the woodland as contrasted to the savannah.

The scrub oak woodland occurs in the Squaw Creek drainage on several areas of 10 acres or less. It has a much different physiognomy from that in adjacent chaparral where this oak is a subdominant. In the woodland community, the trees are 4 to $5 \mathrm{~m}$ high and 3 to $4 \mathrm{~m}$ apart. Mountain mahogany, Eastwoods manzanita, and a few big manzanita are present in the shrub layer.

Forests

Forests are vegetation whose principal dominants exceed 75 feet in height. There are two types that occur in the Big Sulphur - Central Mayacmas range: 


\section{Environmental Consultants}

1. Coastal Ponderosa Pine, made up of yellow pine - manzanita, yellow pine oak, and yellow pine parkland

2. Climax Douglas fir, made up of fir - pine - oak - madrone and Douglas fir - oak

The yellow pine - manzanita community is a low sere association and best developed on the ryolite soils of Cobb Mountain. It consists of yellow pine (Pinus ponderosa) 2 to $75 \%$ and manzanita (A. canesceus, A. viscida and/or A. manzanita) 20 to $60 \%$. A few plants of bush chiquapin and, occasionally, ceanothus prostratus may enter the association.

Pine-oak forests are not widespread but isolated stands occur here and there in the drainage. The best examples are found in the vicinity of P.G. \& E. Unit 13 and Socrates Mine headquarters. The yellow pine - oak type is homologous to the coastal ponderosa pine forest of other classifications. Stand surveys indicate minor variability between stands but the dominants are: western yellow pine, black oak, and madrone. Other common species are: canyon oak, bay (at lower elevations and ecotonal to riparian), sugar pine (Pinus lambertiana), Nuttall's dogwood, squaw carpet, deerbrush, manzanita, chinquapin. The herbaceous layer is highly variable but iris, bracken fern, California fescue and the perennial blue Tupine (Lupinus adsurgens) are common. St. Helen's lupine is also found in this community.

The Yellow Pine Parkland at Caldwell Pines appears to be an uncommon community in the Mayacamas Range, being related to the forests on the volcanic parent material of Boggs Mountain. Because it is more open, it is a parkland where as the Boggs Mountain communities are dense forests; but it is also quite different from the yellow pine parkland of Cobb Mountain. 


\section{Environmental Consultants}

Canopy cover of the pines varies between 40 to $75 \%$. Garry and black oaks are present, but both have a low frequency. Eastwood's manzanita and big manzanita are common tall shrubs. Squaw carpet is common and there are several specimens of the St. Helena ceanothus (C. divergens ssp. confusus). Rock spiraea (Holodiscus boursieri), wild blackberry (Rubus leucodermis), and the rose (Rosa spithmea) occur occasionally.

The more common herbs are Idaho fescue (Festuca Idahoens is), foothill thread and needlegrass (Stipa lepida), narrow-leaved penstemon (Penstemon heterophylla), western cheatgrass (Bromus tectorum), malpias fescue (Festuca megalura), Drew's silky lupine (Lupinus adsurgens) and broad-leaved lupine (Lupinus latifolius).

On Cobb Mountain two types of yellow pine forest occur. The first is found on south and western slopes. Composed of western yellow pine (Pinus ponderosa), 10 to 100\% cover, and scattered sugar pine ( $P$. lambertiana), 0 to $10 \%$ cover, the understory is its distinguishing characteristic. Bracken fern (Pteridium aqualinum), Drew's silky lupine (Lupinus adsurgens var. lilacinus), and iris are the herbaceous dominants. Also occurring are the beautiful cyclademia (Cyclademia humilis), forest madder (Kelloggia gallioides), California bedstraw (Galium californicum) white-flowered hawkweed (Hieracium albiflorum), Applegate's paintbrush (Castilleja applegateii), and the local endemic, St. Helena lupine (Lupine sericatus). Occasionally, a specimen of squaw carpet (Ceanothus prostratus) is found on the forest floor.

The second type occurs on east-facing slopes, and is best developed on moister sites. The tree cover is again western yellow pine (95\%) and sugar pine (5\%), but the understory dominants change noticeably: the bunch grasses (Bromus marginatus and Festuca idahoensis) are dominant,. with bracken fern and Orew's lupine interspersed. In moister areas, the gentian Frasera albicaulis sepmitida occurs. The composite, silver 


\section{Environmental Consultants}

crown (Cacaliopsis nardosmia), is occasionally found on drier sites. In both of these associations, the pine woods lousewort (Pedicularis semibarbata) occurs.

On north-facing slopes, mostly below 4000 feet, Douglas fir (Psuedotsuga menzezii), black oak (Quercus kelloggii), and madrone (Arbutus menzezii) begin to infiltrate the pine forest. This forest is strikingly different from the yellow pine forest in composition, density, and aspect. At the 3200 to 3800 foot level this forest is characterized by Douglas fir, 50 to $70 \%$; western yellow pine, 10 to $30 \%$; black oak, 5 to $30 \%$; and dogwood (Cornus nuttallii) 2 to $10 \%$. In the draws and steep northeast-facing slopes at higher elevations, canyon oak (Quercus chrysolepis) may form 30 to $50 \%$ of the stand. In the lower draws, big leaf maple (Acer macrophyllum) and bay (Umbellularia californica) are common. Occasionally, giant chinquapin (Castanopsis chrysophylla) is found.

Probably the most common shrubs at higher elevations are snowberry (Symphoriocarpus albus) and deerbrush (Ceanothus integerrimus). At middle elevations, coffeeberry (Rhamnus californica), shrubby interior live oak (Quercus wislizenii var. frutescens) and gooseberry (Ribes sp.) are common understory plants. Manzanita is sparsely distributed at all elevations.

The herbaceous understory is usualiy sparse but dịstinctive. Bracken fern is common, as in the pine forest, but different lupine species (Lupinus latifolius and $L_{\text {. }}$ andersoni $i$ ) are found scattered in small colonies. Other distinctive plants are the eracaceous leafless wintergreen (Pyrola aphy11a) and sugarstick saprophyte (Allotropa virgata). The yellow-flowered groundsel, (Senicio aronicoides), and the whiteflowered hawkweed (Hieracium albiflorum), both composites, occur occasionally at middle altitudes. 


\section{Environmental Consultants}

\section{Riparian Vegetation}

These communities are found along water courses, around springs or seeps. Their distinctive composition often allows the tracing of underground water drainages that are not evident otherwise.

The principal indicator of streams, both intermittent and all-year flow types, is big-leaf maple and California bay. Aspect plays an important part in determining the composition and frequency of riparian species. Along Big Sulphur Creek, there is a distinct difference in streamside vegetation from the north to the south exposures. On northfacing, California bay is dominant, although canyon oak and black oak are subdominant, and big-leaf maple is merely present. California grape, wild blackberry, coffeeberry and, occasionally, white alder are found close to water.

Herbs consist of Malpias fescue, chickweed, soft chess, miner's lettuce, dove's foot geranium, knotted hedge parsley, and wormwood; what appears to be garden balm, a garden escape, also grows on these gravelly alluvium benches along the stream. Cyperus eragostis is found growing in tufted bunches among rocks in the riverbed. On the drier southfacing bank, arroyo willow and Garry oak is found. The annual grassland accompanies the oak almost to the water's edge.

Steep west and south watercourses are dominated by big-leaf maple, black oak, and bay. Canyon oak, toyon, and mountain mahogany are common to occasional. Often the toyon - mahogany - silk tassel chaparral association is immediately adjacent to the riparian. Spice bush (Calycanthus occidentalis) is restricted to this type. On these slopes thick stands of bay indicate underground water and cold air drainages. 
Rock cliff communities are restricted to rock outcrops along the bottoms of canyons with (usually) north or east exposures. They are invariably shaded, cool, and moist or at least low transpiration areas. The soil that supports them is highly organic and roots are either shallow or penetrate deeply into the cracks of rocks. There is usually a moss cover next to the ground, mostly Mnium sp. with Homalothecium nut. present along with several foliose lichens. The higher plants distribution are mostly restricted to such sites; California polypody is dominant, but western sword and California maidenhair ferns also occur. Pacific stonecrop (Sedum spathufolia) is usually present. Alum root is always present, but may be there only in small numbers as is gold-backed fern. Also Clarkia gracillis is occasionally present on sunnier slopes.

There are several bog plants that are present at perennial springs and seepages. Bog rush always predominates and Bolander's rush is common but a sub-dominant. In sunny areas, yellow monkey flower and hedge nettle are common. A few species of sedges may also be present, but only in those springs where water is abundant. Around the margins, western wild rye and Bromus enerimus is often present in low numbers. Several species of the annual grassland are also well developed here -soft chess, knotted hedge parsely, and Malpais fescue. Sheep sorrel and white clover may also be found.

\section{Rare \& Endangered Species}

Rare plants include Hot Springs panic grass (Panicum thermale), St. Helena fawn lily (Erthryonium helenae), contact mine sunflower (Helanthus exima), Napa lomaterim (Lomatium repostum) St. Helena lupine (Lupinus sericatus), and Socrates Mine Jewel flower, (Streptanthus 
brachiatus).

The panic grass is limited to two populations: one at the Big Geysers the other at Little Geysers, both on thermally altered soils and in the immediate vicinity of fumeroles, cf. Union 0i1 Big Sulphur EIR. There is considerable doubt about the taxonomic validity of the sunflower and even if the original populations survive from which it was described. The lomatium is not common and appears to be in Lake County rather than in the Big Sulphur - Squaw Creek drainage. The other plants are rare, but shoudl not be considered endangered with the exception of the jewel flower - $\underline{S}$. brachiatus appears to be limited. to the Socrates Mine sites. Other closely related taxa are currently being described, cf. Neilson, 1977.

\section{The Effects of Non-Electrical Development}

As long as non-electrical applications of geothermal energy are confined to existing well pads or already impacted areas, no impact on vegetation should be expected. Similarly, as long as discharge requirements for air quality and water quality are maintained at the same or more stringent levels no impact on vegetation should result.

\section{THE FAUNAL RESOURCE}

The following discussion was taken verbatum, with only corrections made, from "Master Environmental Assessment: The Geyser - Calistoga KGRA" by Stanford Research Institute, 1976. However, much of the material has been taken verbatum from EIR's on the area prepared by ECOVIEW. (Union 0i1, Pacific Energy, and Geothermal Kinetics.) Those portions taken directly from ECOVIEW EIR's are presented in quotes. 
Faunal Habitats

The grassland - oak savannah open habitat, with a variety of grasses and herbaceous plants, provides food for many wildlife species. Blacktailed jack rabbit, quail, and a number of other birds feed on grass species found in this habitat. Field mice, pocket gophers, and other rodents are common. These small mammals are hunted by the coyote, grey fox, ringtail, and several birds of prey, including sparrow hawks. Few wildife species resident to this habitat; most of those that frequent the area use it as a food source while utilizing nearby habitat types for cover.

Transitional zones create an "edge effect" between grassland habitats and adjacent forest or chaparral areas. These edges contain the greatest variety of plant foods. In the spring, an abundance of succulent young grasses and forbs in the ecotone provides nutritional substance for a variety of wildlife.

Deer utilize the grassland habitat for forage in the spring and eat acorns from the valley oaks in the fall. They also frequent the transitional zones on the edge of the grassland habitats. Many browse species grow in the transitional zone; nearby chaparral cover offers an escape from predators.

"The most common amphibian species is the western toad (Bufo boreas), although Pacific treefrogs (Hyla regilla) breed in the vicinity of springs and seeps. Western fence lizards (Sceloporus occidentalis) are particularly abundant around logs and rock outcrops. The rodentdependent gopher snake (Pituophis melanoleucus) is commonly encountered, but a number of other snakes occur as we11." 


\section{Environmental Consultants}

Both the number of bird species and their breeding population densities tend to be relatively low, due to the vegetation structure and heavy grazing by livestock. The American kestrel (Falco sparverius), loggerhead shrike (Lanius ludovicianus), and western meadowlark (Sturnella neglecta) are found only in grassland or savannah areas. These vegetation types are of particular importance as feeding areas for game species, especially California quail (Lophortyx californicus) and mourning dove (Zenaida macroura).

Rodents, particularlly abundant in grasstand communities, provide food for a number of predatory species of snakes, birds, and mammals. Botta's pocket gopher (Thomomys bottae), California ground squirrel (Spermophilus beecheyi), Heermann's kangaroo rat (Dipodomys heermanni), and California vole (Microtus californicus) are found in the greatest numbers. A number of mammalian species that seek cover in nearby broad-leaf woodland or chaparral utilize the grassland and savannah heavily for feeding. These include black-tailed deer (Odocoileus hemionus columbianus), coyote (Canis latrans), striped skunk (Mephitis mephitis), and black-tailed jack rabbit (Lepus californicus).

The dense chaparral canopy shades are herbaceous growth and restricts access, limiting the variety of wildiffe in chaparral habitat. The chaparral area is utilized by birds and mammals primarily as a cover habitat in areas where the chaparral is adjacent to grassland areas or riparian zones, and a transitional zone is formed. In these zones, grassland habitats provide food, riparian areas supply food and water, and chaparral provides adjacent cover. These edge areas are valuable to wildlife.

Bird species common to the chaparral include California quail, scrub jay, bushtit, wrentit, and mockingbird. These birds feed on various seeds, berries, and insects in the area. Plant shoots, along with seeds and berries, provide food for a number of rodent species. Reptile species that prey on resident rodents include the Pacific rattlesnake, common kingsnake, and common gopher snake. Western fence lizards are 


\section{Environmental Consultants}

also present. Coyote, ringtail, grey fox, and bobcat frequent the habitat area, hunting brush rabbits, birds, and small mammals.

In general, wildlife frequent open areas of chaparral rather than mature, dense stands of brush. Easier access, more "edge areas" containing a wider variety of food, and increased quantities of deer-browse and herbaceous growth characterize open chaparral areas.

In the spring, deer are attracted to the chaparral habitat, browsing on tender young brush growth. Among the preferred plants are Ceanothus species, including "deerbrush" and "buckbrush".

Fire increases the value of brush species to wildilfe, especialiy deer. Mature chaparral stands have limited amounts of palatable browse, but fire stimulates the sprouting of brush. species with. tender young leaves. Following a fire, excellent deer browse is found in areas of former chaparral growth. Grasses and herbs also grow well following a fire, providing additional food for deer, rodents, brush rabbits, and quail.

Because of the greater vertical extent and complexity of the vegetative component, the chaparral supports a slightly greater number of bird and mammal species than do grassland and savannah. Although chaparral ranks third among the plant communities in number of vertebrate species that use it as their habitat, only four are restricted to it.

"Several mammalian species, such as the ringtail (Bassariscus astutus) and western spotted skunk (Spilogale gracilis), are almost entirely restricted to the chaparral. Others, including the brush rabbit (Sylvilagus bachmani), Sonoma chipmunk (Eutamias sonomae), brush mouse (Peromyscus boylii), pinyon mouse (Peromyscus truei), dusky-footed wood rat Neotoma fuscipes), Heerman's kangaroo rat (Dipodomys heermanni), and gray fox (Urocyon cinereoargenteus), center their activities within the chaparral although they may inhabit or range into adjacent vegetative 


\section{Environmental Consultants}

communities. The black-tailed deer population utilizes the chaparral heavily as an important source of food and cover for much.of the year."

"The bird fauna is largely dominated by typical California chaparral species. The sage sparrow (Amphispiz belli) is of particular interest because it is narrowly restricted to the chamise brushland on southfacing slopes; near the western margin of its range in this region. Many breeding pairs were noted in June. The chaparral is of importance in providing cover, nesting sites, and food for a sizable population of California quail.".

"Amphibians are relatively scarce in the chaparral, although Pacific treefrogs can be found in the montane chaparral near springs. Western fence lizards are the most abundant reptiles, especially in more open areas, and a.variety of snakes occur, including the striped racer (Masticophis lateralis), which is almost exclusively a chaparral species."

"The broad-leaf woodland communities, as considered with respect to animals, include both deciduous and evergreen broad-leaf woodland communities, since their faunas are very similar. These communities are important because of their relatively great areal extent and high species diversity... - Seven species, including five birds, are restricted to broad-leaf woodland vegetation."

Amphibians in the forest habitat include newts, toads, Pacific treefrog, and western skink. "Five species of salomander are found. The ensantina (Ensantina eschscholtzi) and the arboreal salomander (Ancides lugubris) are typica1."

Reptiles include rubber boa, king snake, common gopher snake, and Pacific rattlesnake. (King snakes have been introduced into the project area to reduce'local. rattlesnake populations:) Sharp-tailed snakes also frequent the area, along with the western fence lizard. "Western fence lizards are common, but the western skink (Eumeces 
skiltonianus) and foothill alligator lizard (Gerrhonotus multicarinatus) are sometimes encountered as well. A wide variety of snakes is to be expected."

Madrone-oak and conifer woodlands provide cover and food for many birds, including scrub jay, Stellar's jay, brown creeper, California and mountain quail, black-headed grosbeak, Oregon junco, and wrentit. California quail are found in all habitat types, but mountain quail are restricted to woodland habitats. A variety of woodpeckers, including hairy, downy, and red-shafted flicker, feed on wood-boring insects and other tree anthropods. Pileated woodpeckers and blue grouse are common visitors to the forest habitat.

Red-tailed hawk, Cooper's hawk, sharp-shinned hawk, great horned owl, and screech owl are common birds of prey. Red-tailed hawks' nests have been observed in several parts of the woodland habitat throughout the KGRA.

"Shrews, bats, and rodents are the most numerous components of the manmalian fauna. The western gray squirrel (Sciurus griseus), Botta's pocket gopher, deer mouse (Peromyscus manicalatus), brush mouse, and dusky-footed woodrat are especially common and widespread species within these communities. Black-tailed deer are the commonest large mammals and utilize the broad-leaf woodlands extensively." Bobcats and black bears are occasionally encountered.

The fauna of the knobcone pine communities are the least diverse of the major habitat groups, containing only 35 species of vertebrates, none of which are restricted to these communities. Indeed, most of the species occurring in these forests have wide ecological ranges or also occur in the chaparral communities and frequently use the knobcone pine stands solely for cover. 


\section{Environmental Consultants}

The cypress and particularly the yellow pine stands are of considerably greater value as wildlife habitat. They contain an abundance of seeds, which attract western gray squirrels, Townsend chipmunks and Sonoma chipmunks. Numerous rodents also frequent the area, including Botta's pocket gopher, Trowbridge shrew, broad-handed mole, the brush mouse, dusky-footed wood rat, Sonoma chipmunk, and western mole. Near riparian areas, raccoon, porcupine and black-tailed hare utilize the knobcone pine habitat for cover. Black-tailed deer also pass through this habitat area, but the dense stands of cypress severly limit access.

Many bird species use the dense cover in this area for shelter and nesting sites, and find food in the form of seeds, anthropods, and tree-burrowing insects. These bird species include hairy and downy woodpeckers, red-shafted fiicker, wrentit, brown creeper, and Oregon junco. Sparrow hawks, Cooper's hawk, and screech owls are common birds of prey. Bird species associated with adjacent chaparrel areas frequent the cypress habitat. These include scrub jay, wrentit, and rufoussided towhee. The cypress habitat type is estimated to have the lowest wildlife population of all habitat types with the project area.

Several reptiles frequent the yellow pine and fir stands, including the common gopher snake, western fence lizard, sharp-tailed snake, Pacific rattlesnake, and California mountain king snake.

Amphibians include the Pacific tree frog and the red-bellied and rough skinned newts, which are active in the spring when moisture is abundant.

Amphibians rarely occur in the cypress associations and the most abundant reptile there is undoubtedly the western fence lizard. 
The riparian habitat type, although sparse within the project area, provides many habitat essentials for local wildlife populations. However, it is being destroyed at a rapid rate. It preservation, for the sake of aesthetic values and -- more importantly -- for wildlife preservation, is a matter of critical concern (California Office of Planning and Research, 1973).

Riparian habitat zones in the project area are limited to narrow strips of influence along stream courses. This habitat provides an abundant supply of nutritional foods for many wildlife species. With available water and interlacing cover, the riparian zone is an ideal habitat for these species. During the summer, the water and nutrient content of grasses and forbs stays at a higher level than in surrounding habitat areas. Critical food links in the ecological pyramid are also provided in riparian zones.

Wet meadows, a subtype of the riparian habitat, are summer areas for many mammals, and are heavily used by waterfowl and other birds in the winter. However, there are few meadows within the KGRA.

At the lower trophic levels in the riparian ecosystem, many anthropods, including insects, spiders, and crustaceans, are found. Many food chains begin with these organisms. Fish live on aquatic insects and their larvae, and various birds feed on the variety of insects. Birds are abundance in riparian zones within the project site.

Reptiles and amphibians are included in the next higher trophic levels of the riparian ecosystem. Bullfrogs and newts are common, together with the western toad, Pacific tree frog, and salamander species. Aquatic garter snakes are present, along with the comon garter snake, Pacific gopher snake, and Pacific rattlesnake. These reptiles prey on 


\section{Environmental Consultants}

meadow mice, muskrats, Botta pocket gophers, ornate shrew, Trowbridge shrew, and moles. Upper drainage areas provide water and good hunting areas for other predators, including coyote, bobcat, ringtail and mountain lion. Raccoons and porcupines also are present in the riparian habitat, as are oppossum and striped skunk.

Deer migrate along primary wildlife corridors parallel to riparian zones, but generally approach the riparian zones only after the sun has set. They prefer succulent riparian browse species for food in summer months and early fall, when the new growth on chaparral species has lost its moisture content and hardened. Since deer depend largely on riparian vegetation, the quality of riparian browse species indicates the health of local deer herds. Within the project site, moderate-to-heavy browsing of riparian browse species is occurring, indicating that local deer populations are nearing, or have exceeded, the carrying capacity of the area. With continued development in the project site, especially in areas of prime deer habitat, pressure on riparian zones to provide adequate forage for resident deer herds will increase.

"Considering the relatively small area covered by this community, it supports a remarkably rich vertebrate fauna. Of particular interest are large populations of red-bellied newts (Taricha rivularis), which spend the dry season in a state of dormancy in subsurface burrows and crevices. In late winter, they migrate hundreds of meters downslope and enter the creeks where they form breeding aggregations from February through April. Their small egg masses are laid under rocks in swiftflowing parts of the streams, and the larvae spend the summer months in the water. Smaller populations of rough-skinned newts (Taricha granulosa) follow a similar annual cycle, but breed in stream sections with lower water velocity. Several species of amphibians and reptiles are restricted to the riparian zone throughout the year, including the Pacific giant salamander (Dicamptoden ensatus), yellow-legged frog (Rana boylei), and 
Environmental Consultants

western aquatic garter snake (Thamnophis couchi)."

"A large and diversified bird fauna is found in the riparian community, in part because of a varied and abundant food supply and in part because of the complex vegetative cover. Certain species, such as the belted kingfisher (Megaceryle alcyon), a black phoebe (Sayornis nigricans), and dipper (Cinclus mexicanus), are found only in this zone. Several species of swallows, thrushes, warblers, and sparrows have their major centers of activity here. Many migrants utilize the riparian strips for resting and feeding during their spring and fall stopovers."

"Al though a number of mammals range through the riparian areas, only one, the opossum (Didelphis virginiana), is restricted to streamside vegetation. However, this community is of importance as a hunting area to many species of bats, shrews, and carnivores."

\section{Rare and Endangered Fauna Species}

"Peregrine falcons have been observed in the Geysers region, and have been known to nest in the cliffs on the west side of Cobb Mountain (Merlin F. Hehnke, U. S. Dept. of Interior, Fish and Wildlife Service). According to this experienced source, a single bird was fledged in the summer of 1973. The area is favorable for the nesting of other raptors, as well. Aside from this limited area, no other special use that is not shared by the Mayacmas range as a whole since these birds and other large raptors range over wide territories in their feeding activities."

No other rare or endangered animal species is known to occur in the area based upon current field surveys and a search of the pertinent 1iterature. ECOVIEW cannot completely rule out the possibility at other seasons of the year, but we do not consider it likely. 


\section{1}

Environmental Consultants

No other rare or endangered animal species is known to occur in the area based upon current field surveys and a search of the pertinent 1iterature. ECOVIEW cannot completely rule out the possibility that other rare or endangered species may be present, especially at other seasons of the year, but we do not consider it likely. 